UNIVERSIDADE DE SÃO PAULO

FACULDADE DE FILOSOFIA, LETRAS E CIÊNCIAS HUMANAS DEPARTAMENTO DE CIÊNCIA POLÍTICA

RIBAMAR CEZAR RAMBOURG JÚNIOR

A crise na coalizão e o impeachment de Dilma Rousseff

São Paulo

2019 
RIBAMAR CEZAR RAMBOURG JÚNIOR

A crise na coalizão e o impeachment de Dilma Rousseff

\section{Versão Original}

Dissertação apresentada à Faculdade de Filosofia, Letras e Ciências Humanas da Universidade de São Paulo para obtenção do título de Mestre em Ciência Política.

Área de Concentração: Ciência Política

Orientador: Prof. Dr. Fernando de Magalhães Papaterra Limongi

São Paulo 
Autorizo a reprodução e divulgação total ou parcial deste trabalho, por qualquer meio convencional ou eletrônico, para fins de estudo e pesquisa, desde que citada a fonte.

Catalogação na Publicação

Serviço de Biblioteca e Documentação

Faculdade de Filosofia, Letras e Ciências Humanas da Universidade de São Paulo

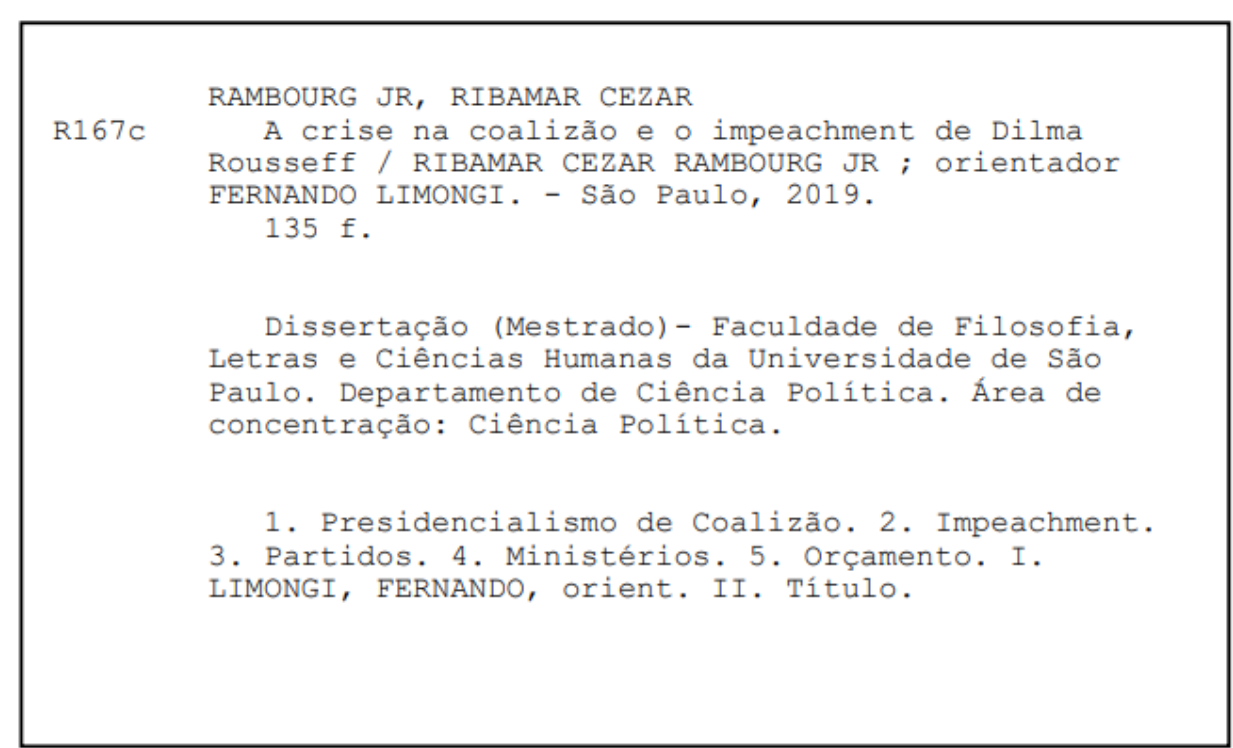


Nome: RAMBOURG Jr., Ribamar Cezar

Título: A crise na coalizão e o impeachment de Dilma Rousseff

Dissertação apresentada à Faculdade de Filosofia, Letras e Ciências Humanas da Universidade de São Paulo para obtenção do título de Mestre em Ciência Política.

Aprovado em:

Banca Examinadora

Prof. Dr.

Instituição:

Julgamento:

Prof. Dr.

Instituição:

Julgamento:

Prof. Dr.

Instituição:

Julgamento: 


\section{RESUMO}

RAMBOURG Jr., R. C. A crise na coalizão e o impeachment de Dilma Rousseff. 2019. 135 f. Dissertação (Mestrado em Ciência Política) - Faculdade de Filosofia, Letras e Ciências Humanas, Universidade de São Paulo, São Paulo, 2019.

O trabalho se dispõe a analisar a relação da chefe do Poder Executivo com os partidos membros da coalizão de governo durante o mandato de Dilma Rousseff. Embora a presidente tenha sido reeleita e governado com apoio de uma coalizão amplamente majoritária no Congresso Nacional, ela foi afastada por meio de impeachment. Sem adentrar no mérito do processo, o trabalho avaliará o esfacelamento da coalizão que, em circunstâncias adversas, a tornou suscetível de ser destituída pelo Poder Legislativo. Em outras palavras, a presidente não conseguiu construir escudo legislativo para lhe proteger em momentos de crise. Conforme será apresentado na dissertação, o apoio congressual ao governo caiu de forma contínua ao longo do tempo. Desde que tomou posse, Dilma Rousseff optou por não cultivar uma relação próxima com os partidos da coalizão, o que pode ser explicitado, sobretudo, pela desproporção na composição ministerial entre os partidos da coalizão e por conflitos permanentes existentes entre a presidente e seus aliados. Em relação à composição ministerial, será avaliado o orçamento total de investimento que os partidos conseguem empenhar por meio dos ministros indicados para compor o gabinete - uma vez que investimentos trazem maior visibilidade, podendo suscitar ganhos políticos aos agentes e partidos envolvidos. Assim, em meio a dificuldades políticas, quando a crise econômica e os escândalos de corrupção levaram milhões de pessoas às ruas pedindo sua destituição, Dilma Rousseff não resistiu. No auge de sua impopularidade e na ausência de escudo legislativo, o impeachment tornou-se inevitável.

Palavras-chave: Presidencialismo de Coalizão. Impeachment. Partidos. Ministérios. Orçamento. 


\begin{abstract}
RAMBOURG Jr., R. C. The coalition crisis and the impeachment of Dilma Rousseff. 2019. 135 f. Dissertação (Mestrado em Ciência Política) - Faculdade de Filosofia, Letras e Ciências Humanas, Universidade de São Paulo, São Paulo, 2019.

The paper proposes to analyze the relationship of the head of the Executive Branch with the parties that composed the coalition government during Dilma Rousseff's term. Although the President had been re-elected and ruled with the support of a wide majority coalition in the National Congress, she was removed by impeachment. Without delving into the merit of the process, the work will evaluate the collapse of the coalition that, in adverse circumstances, made possible the dismissal of the President by the Legislative Branch. In other words, the president failed to build legislative shield to protect herself in times of crisis. As will be presented in the dissertation, congressional support for the government has fallen steadily over time. Since taking office, Dilma Rousseff has chosen not to cultivate a close relationship with the coalition parties, which can be explained above all by the disproportionate ministerial composition between these parties and the ongoing conflicts between the president and her allies. Regarding the ministerial composition, the work will evaluate the total investment budget that the parties are able to commit through the ministers appointed to make up the cabinet - since investments bring greater visibility and can generate political gains for the agents and parties involved. Thus, amidst political difficulties, when the economic crisis and corruption scandals brought millions of people to the streets calling for her dismissal, Dilma Rousseff did not resist. At the height of her unpopularity and in the absence of a legislative shield, impeachment became inevitable.
\end{abstract}

Keywords: Coalition presidentialism. Impeachment. Parties. Ministries. Budget. 


\section{LISTA DE FIGURAS}

Figura 1. Apoio ao Governo na Câmara dos Deputados - Partidos da Coalizão. Governo FHC. ......... 33

Figura 2. Apoio ao Governo na Câmara dos Deputados - Partidos da Coalizão. Governo Lula.......... 33

Figura 3. Apoio ao Governo na Câmara dos Deputados - Partidos da Coalizão. Governo Dilma....... 37

Figura 4. Investimentos dos Ministérios - Por Partido. Governo Lula I............................................... 44

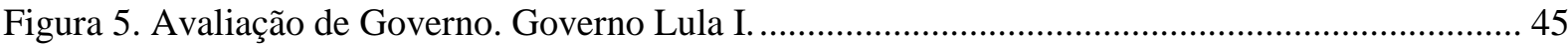

Figura 6. Investimentos dos Ministérios - Por Partido. Governo Lula.................................................. 49

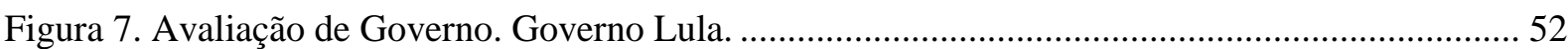

Figura 8. Investimentos dos Ministérios - Por Partido. Governos Lula II e Dilma I............................ 56

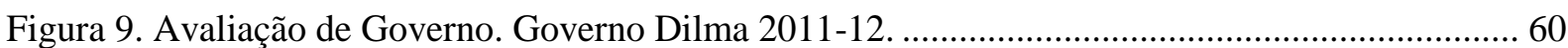

Figura 10. Apoio ao Governo na Câmara dos Deputados - Partidos da Coalizão. Governo Dilma I... 65

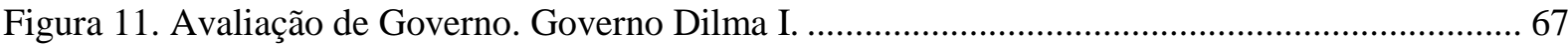

Figura 12. Apoio ao Governo na Câmara dos Deputados - Partidos da Coalizão. Governos Lula e

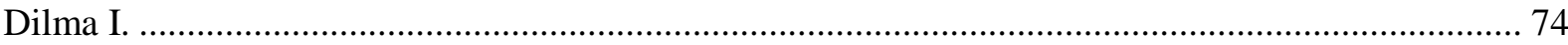

Figura 13. Investimentos dos Ministérios - Por Partido. Governo Dilma 2011-15............................. 76

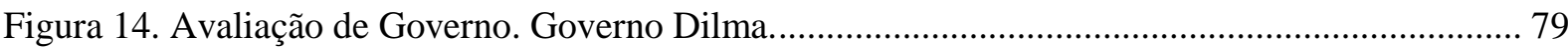

Figura 15. Investimentos dos Ministérios - Por Partido. Governo Dilma. ............................................. 85

Figura 16. Votos favoráveis à abertura do impeachment - Partidos da Coalizão. Câmara dos

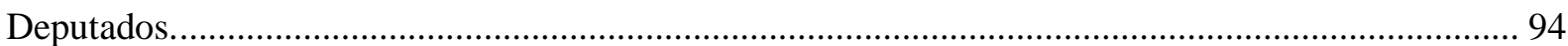

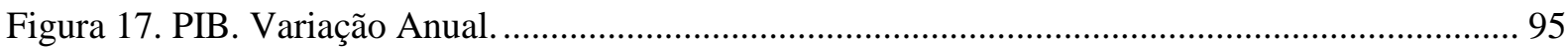

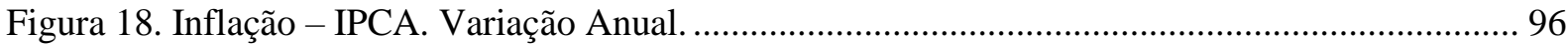

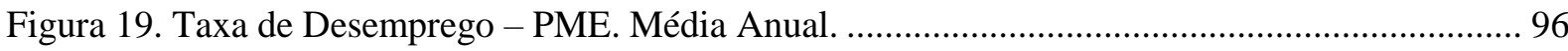

Figura 20. Apoio ao Governo na Câmara dos Deputados - Partidos da Coalizão. Governos Lula e

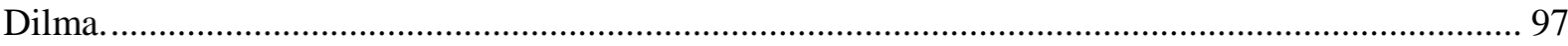

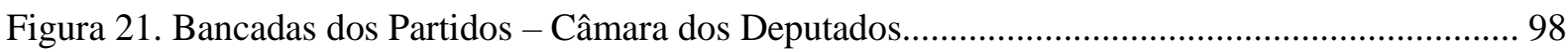

Figura 22. Investimentos dos Ministérios - Por Partido. Governos Lula e Dilma................................ 99

Figura 23. Avaliação de Governo. Governos Lula e Dilma. ................................................................. 102 


\section{LISTA DE TABELAS}

Tabela 1. Coalizões de governo durante o período 1995-2016.......................................................... 35

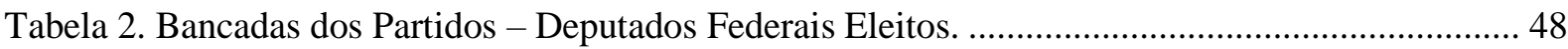

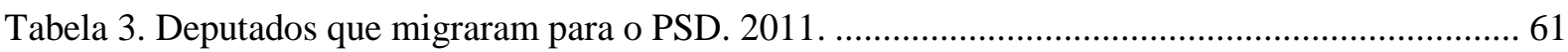

Tabela 4. Bancadas dos Partidos - Deputados Federais Eleitos ....................................................... 125

Tabela 5. Líderes do Governo e Presidentes das Casas Legislativas .................................................. 125

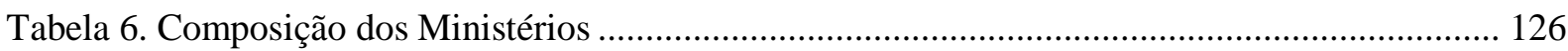

Tabela 7. Orçamento de Investimento - Ministérios ......................................................................... 132

Tabela 8. Dirigentes - Principais Empresas Estatais .......................................................................... 134

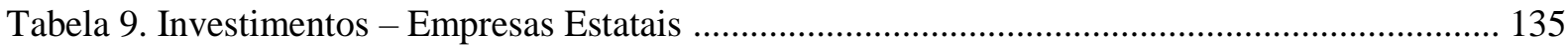

Tabela 10. Investimentos - Empresas Estatais - Por Partido ............................................................ 135 


\section{LISTA DE ABREVIATURAS E SIGLAS}

PCB - Partido Comunista Brasileiro

PCdoB - Partido Comunista do Brasil

PDT - Partido Democrático Trabalhista

PFL/DEM - Partido da Frente Liberal/Democratas

PL/PR - Partido Liberal/Partido da República

PMDB - Partido do Movimento Democrático Brasileiro

PMN - Partido da Mobilização Nacional

PPB/PP - Partido Progressista Brasileiro/Partido Progressista

PPS - Partido Popular Socialista

PRB - Partido Republicano Brasileiro

PRN - Partido da Reconstrução Nacional

PROS - Partido Republicano da Ordem Social

PSB - Partido Socialista Brasileiro

PSC - Partido Social Cristão

PSD - Partido Social Democrático

PSDB - Partido da Social Democracia Brasileira

PT - Partidos dos Trabalhadores

PTB - Partido Trabalhista Brasileiro

PTC - Partido Trabalhista Cristão

PTN - Partido Trabalhista Nacional

PV - Partido Verde 


\section{Sumário}

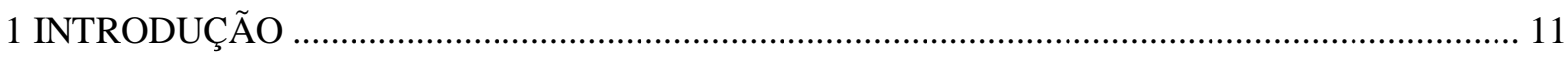

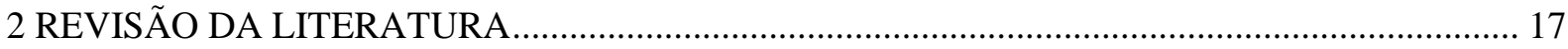

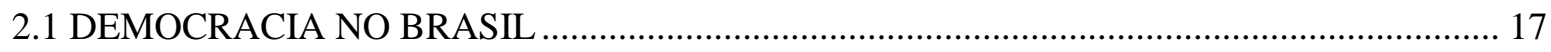

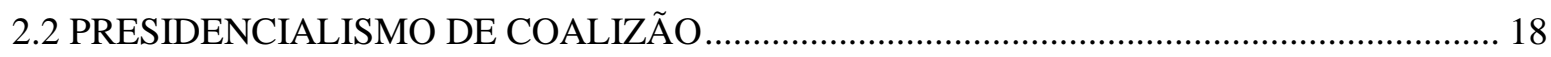

2.3 COALIZÕES NO PARLAMENTARISMO E NO PRESIDENCIALISMO ............................. 21

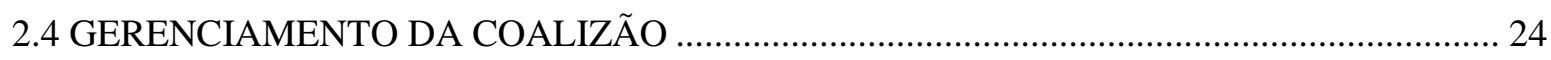

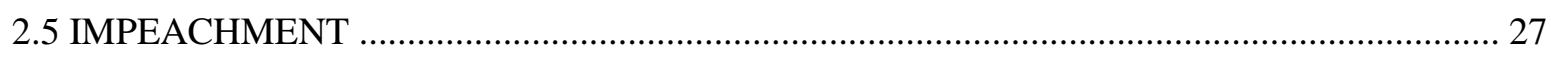

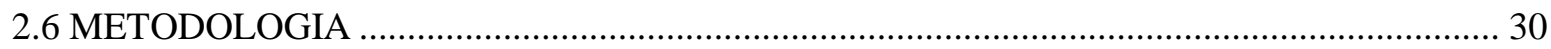

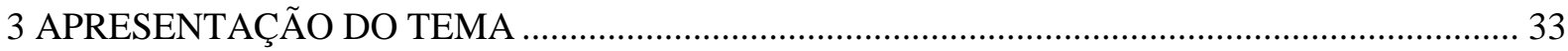

4 O PT NA PRESIDÊNCIA: APRENDENDO A DIVIDIR O PODER SOB LULA …........................ 39

4.1 A ELEIÇÃO DE SEVERINO CAVALCANTI E O MENSALÃO .......................................... 42

4.2 LULA REELEITO E A ALIANÇA FORMAL COM O PMDB ............................................... 46

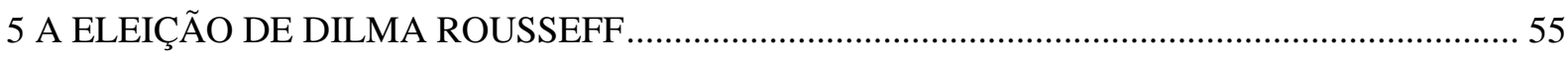

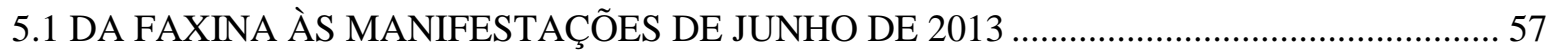

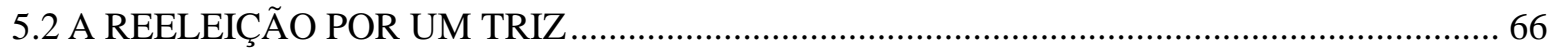

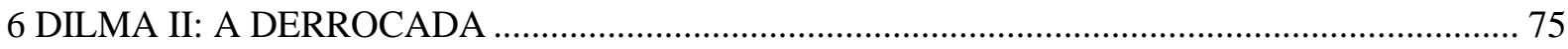

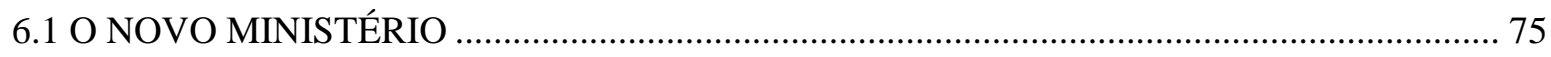

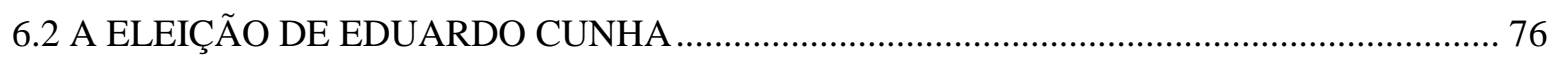

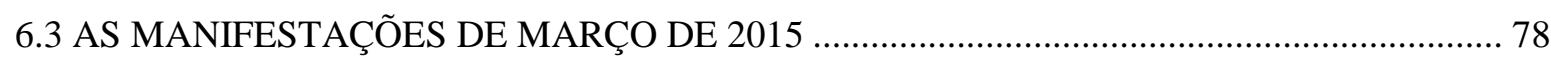

6.4 MICHEL TEMER ASSUME A ARTICULAÇÃO POLÍTICA …………................................ 80

6.5 O MÊS DE AGOSTO: PAUTA-BOMBA E O AFASTAMENTO DE TEMER ....................... 82

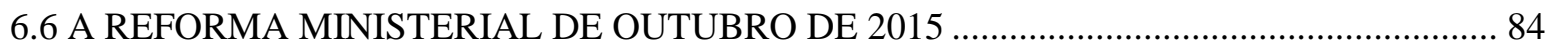

6.7 A PRISÃO DE DELCÍDIO E A ABERTURA DO IMPEACHMENT ........................................ 85

6.8 A CONDUÇÃO COERCITIVA DE LULA E O COMEÇO DO FIM ...................................... 89

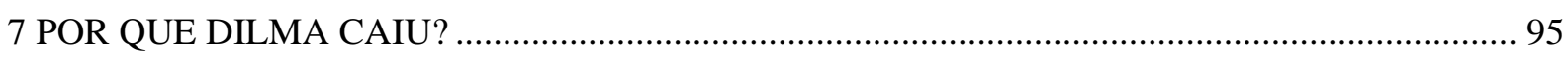

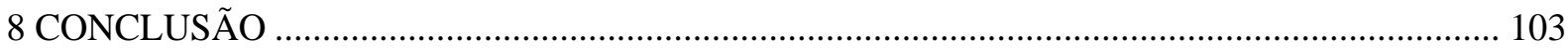

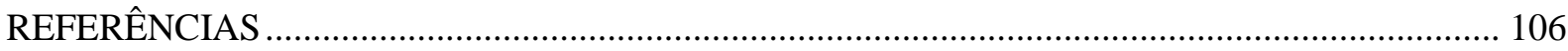

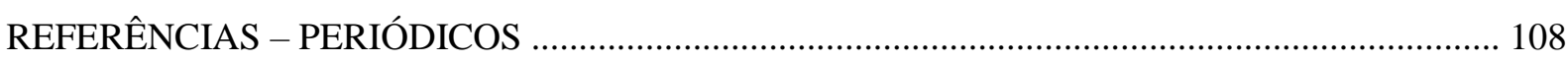

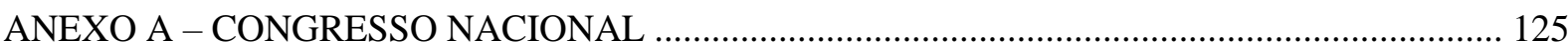

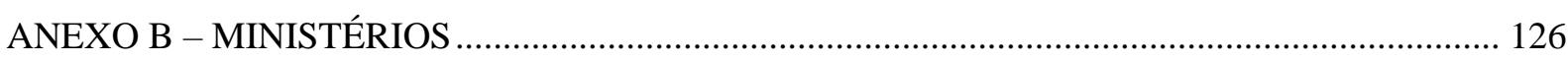

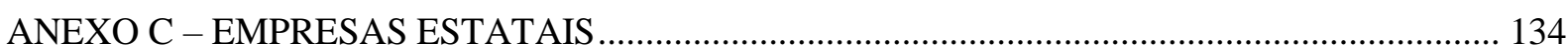




\section{INTRODUÇÃO}

O presente trabalho se propõe a avaliar a relação da chefe do Poder Executivo com os partidos da coalizão de governo durante o mandato de Dilma Rousseff (2011-2016), presidente que foi reeleita pelo voto popular e dispôs de maioria congressual ao longo de seu governo, mas acabou destituída por meio de processo de impeachment.

Dilma Rousseff foi eleita presidente da República em 2010 com o suporte de ampla coligação de partidos. Além do PT, apoiaram a sua eleição o PMDB, o PSB, o PR, o PRB, o PDT, o PCdoB, o PSC, o PTC e o PTN. Após o pleito, esses mesmos partidos formaram a coalizão de apoio ao governo no Congresso Nacional. Além disso, o PP, que não integrou a coligação eleitoral, aderiu à coalizão de governo. Assim, em 2011, a base aliada totalizou o apoio de 349 deputados, número mais do que suficiente para aprovação de emendas constitucionais. Ao longo deste primeiro quadriênio, a coalizão sofreu alterações: o PSB deixou a base de apoio ao governo enquanto o PSD e o PROS ingressaram na base governista.

Dilma Rousseff foi reeleita em 2014 por coligação formada por PT, PMDB, PSD, PP, PR, PRB, PDT, PCdoB e PROS. Esses mesmos partidos formaram a coalizão de governo após a eleição, totalizando o apoio de 303 deputados - número ligeiramente abaixo do quórum necessário para alterar a Constituição.

Como dito acima, não obstante a coalizão de governo reunir o apoio da maioria do Congresso Nacional, Dilma Rousseff não conseguiu concluir seu mandato, sendo alvo de processo de impeachment, que a afastou definitivamente da Presidência da República em 31 de agosto de 2016. A Câmara dos Deputados autorizou a abertura do processo contra a presidente com 367 votos favoráveis (eram necessários 342), sendo que 184 desses votos foram de deputados pertencentes à coalizão de governo. No julgamento final pelo Senado Federal, o placar foi de 61 votos favoráveis à condenação, sendo que a antiga base de sustentação da presidente contribuiu com 34 votos. Esses resultados conduzem à discussão acerca da relação da presidente com sua base de apoio no Congresso Nacional, já que o impeachment precisa de amplo apoio parlamentar para ser viabilizado.

É importante ressaltar que não se pretende discutir a legitimidade do processo de impeachment, tampouco avaliar a ocorrência ou não de crime de responsabilidade. $\mathrm{O}$ processo de afastamento presidencial tem natureza político-jurídica e sua discussão ultrapassa os objetivos que se pretende abordar neste trabalho. O que se almeja é analisar sobretudo a relação entre a chefe de governo e a coalizão ao longo do período em que Dilma Rousseff ocupou a presidência da República, já que Pérez-Liñán elenca, dentre os elementos necessários para a 
ocorrência do impeachment, a perda de apoio congressual do chefe do Poder Executivo (PÉREZ-LIÑÁN, 2007). Nesse sentido, avaliar-se-á o esfacelamento da coalizão de governo ao longo do tempo. Em outras palavras, buscar-se-ão as razões pelas quais a presidente não conseguiu construir escudo legislativo - o que poderia ter garantido a sua permanência no cargo, mesmo em circunstâncias adversas.

Desde a redemocratização e a promulgação da nova Constituição em 1988, dois presidentes eleitos pelo voto popular não conseguiram concluir seus mandatos: Fernando Collor de Mello e Dilma Rousseff. As circunstâncias de cada caso, entretanto, são distintas. Collor foi eleito por um pequeno partido, o PRN, e não conseguiu construir uma coalizão de governo majoritária no Congresso. Dessa forma, tornou-se vulnerável às investidas contra o seu mandato. Dilma Rousseff, por sua vez, tomou posse com o apoio de coalizão de governo amplamente majoritária; sua queda, portanto, demanda maiores explicações. Os demais presidentes eleitos após a redemocratização, Fernando Henrique Cardoso e Luiz Inácio Lula da Silva, precisaram articular a construção de maioria congressual ao longo do tempo; ambos, contudo, conseguiram superar as adversidades e obtiveram relativo sucesso na relação com o Poder Legislativo. Durante o governo de Dilma Rousseff, por sua vez, os conflitos entre a presidente e a coalizão de partidos aliados se acirraram no decorrer dos anos ${ }^{1}$.

Já na formação do seu primeiro gabinete, a presidente reorganizou os espaços dos partidos no ministério. O PMDB, principal legenda da coalizão governista ao lado do PT, perdeu as pastas da Saúde e da Integração Nacional, ambas com dotações orçamentárias importantes e que estiveram sob comando de peemedebistas durante o segundo governo Lula.

Ao longo de seu primeiro ano de mandato, a presidente promoveu "faxina ética" na Esplanada dos Ministérios, afastando ministros suspeitos de envolvimento com corrupção; foram demitidos os presidentes nacionais do PDT e do PR. No final de 2011, foi criado o PSD, organizado pelo prefeito de São Paulo, Gilberto Kassab. A iniciativa foi apoiada pelo governo federal, que enxergou na nova legenda uma oportunidade de depender menos do apoio do PMDB e de outros partidos aliados para obter maioria congressual.

Em 2013, o deputado Henrique Eduardo Alves, líder do PMDB, se elegeu presidente da Câmara dos Deputados, sendo sucedido, na liderança do partido, por Eduardo Cunha. A relação entre o novo líder e Dilma Rousseff sempre foi tumultuada. No primeiro semestre de 2013, a agenda prioritária da presidente foi a reforma do marco regulatório do setor portuário, realizada por meio da edição de medida provisória. A aprovação só foi possível após mais de quarenta

\footnotetext{
${ }^{1}$ Os conflitos políticos descritos a seguir serão expostos, de modo detalhado, ao longo do trabalho, com as devidas referências.
} 
horas de debates e superada a forte resistência de Eduardo Cunha. Em 2014, ano de eleição presidencial, Cunha organizou, ao lado de outros líderes aliados, a formação de um bloco de partidos para negociar em melhores condições o apoio a projetos de interesse do Executivo. $\mathrm{O}$ líder do PMDB, desde então, almejava substituir o deputado Henrique Eduardo Alves na presidência da Câmara a partir do biênio seguinte e tratou de construir boa interlocução com os partidos.

A formação da coligação eleitoral de Dilma Rousseff em 2014 também não foi tarefa simples. A convenção nacional do PMDB formalizou o apoio à reeleição da presidente por margem relativamente apertada - 59\% dos votos dos convencionais - e somente após intervenção do presidente da legenda e vice-presidente da República, Michel Temer. A convenção do PP que formalizou o apoio ao PT foi alvo de intensas disputas. Além disso, a decisão do PT de lançar candidaturas próprias para os principais governos estaduais desgastou ainda mais a relação com os partidos da coalizão, sobretudo com o PMDB.

Após a reeleição de Dilma Rousseff, em outubro de 2014, o tema principal da agenda política passou a ser a eleição para a presidência da Câmara dos Deputados, prevista para acontecer em fevereiro de 2015. O Palácio do Planalto se empenhou em impedir a vitória do líder do PMDB; sem sucesso. Eduardo Cunha se elegeu presidente em primeiro turno e sem o apoio do PT, que lançou candidatura própria.

Em 2015, após assumir seu segundo mandato, Dilma nomeou o economista Joaquim Levy como novo ministro da Fazenda e enviou ao Congresso várias medidas de ajuste fiscal, contrariando o discurso utilizado na campanha eleitoral e o seu próprio partido, o PT. A relação tumultuada com Eduardo Cunha e a oposição da própria base governista às medidas impediram a aprovação de boa parte da agenda econômica pretendida pelo governo.

No final de 2015, o PT decidiu votar pela abertura do processo de cassação de Eduardo Cunha no Conselho de Ética da Câmara dos Deputados, o que levou o presidente da Câmara a determinar a abertura de processo de impeachment contra Dilma Rousseff. É importante mencionar que, nessa época, já havia amplas manifestações nas ruas contra a presidente e sua popularidade estava em curva acentuada descendente.

Por fim, o comportamento da presidente em relação ao avanço da Operação Lava-Jato, que atingiu boa parte da classe política brasileira, pode ter sido elemento decisivo para o seu afastamento. Nesse aspecto, Limongi (2017) avalia que Dilma Rousseff tentou responsabilizar o governo de seu antecessor e o Poder Legislativo pelos casos de corrupção. Em diversas manifestações públicas, a presidente demonstrou apoio irrestrito à Operação Lava-Jato. Contudo, a prisão em flagrante do líder do governo, senador Delcídio do Amaral, em novembro 
de 2015, e a condução coercitiva do ex-presidente Lula, em março de 2016 - e, em seguida, a tentativa frustrada de nomeá-lo ministro da Casa Civil do governo -, evidenciaram, de forma cabal, o enfraquecimento da presidente e o fracasso de sua estratégia em relação à Operação Lava-Jato. O encadeamento desses episódios parece estar diretamente relacionado à decisão do Congresso Nacional de afastá-la do cargo.

Embora não esteja relacionado inteiramente com o gerenciamento da coalizão, a relação entre Dilma Rousseff e Lula, seu antecessor e padrinho político, precisará ser esmiuçada. Em extensa reportagem realizada por Pinheiro (2014) durante as eleições de 2014, a presidente chegou a ser apontada como "afilhada rebelde". Nos meses que antecederam ao pleito, não foram poucas as sugestões para que Lula assumisse a candidatura presidencial do Partido dos Trabalhadores, em detrimento de Dilma. Tais ruídos podem indicar não somente afastamento entre os dois mandatários, mas, sobretudo, dificuldades de relacionamento da presidente com seu próprio partido, o PT.

Ademais, será conveniente a comparação entre o gerenciamento da coalizão durante as gestões de Lula e Dilma Rousseff, com intuito de verificar o desempenho do PT na função de partido formador da coalizão. Ambos os presidentes enfrentaram dificuldades na relação com o Congresso Nacional. Logo no início do governo Lula, eclodiu o escândalo do mensalão e o afastamento do presidente chegou a ser cogitado. Contudo, ele foi reeleito e conseguiu articular ampla coligação de apoio a Dilma Rousseff nas eleições de 2010. Já a presidente, mesmo com apoio majoritário no Congresso, viu os conflitos com os aliados se aprofundarem ao longo do tempo. Dilma Rousseff não resistiu à crise política e ao escândalo do petrolão - em outras palavras, ela falhou ao não obter sucesso na construção de um escudo legislativo para lhe proteger em momentos difíceis. Se a relação com Congresso Nacional tivesse seguido outros rumos, possivelmente, o impeachment não teria sido aprovado, de acordo com as conclusões de Pérez-Liñán (PÉREZ-LIÑÁN, 2007).

No presidencialismo de coalizão, o chefe do Executivo precisa articular a formação de aliança que lhe garanta o apoio de maioria sólida no Poder Legislativo. Se for bem-sucedido nessa tarefa, não deverá encontrar maiores dificuldades para aprovar seus projetos. A construção da coalizão envolve uma negociação: o presidente compõe seu ministério com partidos aliados, distribuindo pastas e garantindo a eles papel relevante na formulação de políticas públicas; em contrapartida, os partidos se comprometem a disponibilizar os votos para aprovação dos projetos do Executivo (FIGUEIREDO; LIMONGI, 1999). Nesse contexto, será preciso analisar como Dilma Rousseff perdeu o apoio de sua base de sustentação no Congresso Nacional. Para tanto, avaliar-se-á o grau de apoio ao governo nas votações das matérias mais 
relevantes ao longo do tempo. Como forma de encontrar explicações para o esfacelamento da coalizão, analisar-se-á a formação do ministério e se a presidente, ao compor o seu gabinete, privilegiou alguns partidos em detrimento de outros, gerando insatisfação em sua base de apoio. No que toca à distribuição de cargos, o enfoque será a alocação orçamentária para investimento entre as pastas ministeriais comandadas pelos diversos partidos vis a vis a composição do Congresso Nacional, como forma de mensurar o compartilhamento do poder entre os partidos da coalizão. Também será importante apresentar os conflitos, recorrentes, entre a presidente e sua base de sustentação, conforme evidenciado resumidamente nos parágrafos acima.

O trabalho será composto por esta introdução, seis capítulos com o desenvolvimento do tema e uma conclusão. O segundo capítulo traçará uma breve revisão da literatura e será dividido em seis seções, nas quais se discutirá a evolução da democracia no Brasil, o presidencialismo de coalizão, a formação de coalizões no presidencialismo e no parlamentarismo, as formas de gerenciamento da coalizão de governo no Brasil e as condições políticas necessárias para abertura do processo de impeachment. Ao final do capítulo, será apresentada a metodologia do trabalho, que consistirá na avaliação do apoio ao governo no Congresso Nacional, por meio dos dados do CEBRAP (Centro Brasileiro de Análise e Planejamento); e, por outro lado, na análise do orçamento de investimento dos ministérios controlados pelos partidos, por meio dos dados do SIAFI (Sistema Integrado de Administração Financeira do Governo Federal). Além disso, serão expostos eventos que apontem a existência de conflitos entre a presidente e a coalizão.

O terceiro capítulo cuidará de apresentar o tema da dissertação, qual seja, a crise que culminou no afastamento de Dilma Rousseff por meio do impeachment. Neste capítulo, serão expostos os resultados do presidencialismo de coalizão no Brasil nas últimas décadas, sobretudo no que toca ao desempenho legislativo. Como se verá ao longo da revisão de literatura, o Poder Executivo dispõe dos instrumentos necessários para aprovar projetos no Congresso Nacional. Dilma Rousseff formou coalizão majoritária, mas, ainda assim, assistiu à queda do apoio legislativo ao governo ao longo dos anos. Os capítulos seguintes tratarão de oferecer explicações para isso, tendo como foco a composição ministerial e a relação com os partidos da coalizão.

O quarto capítulo avaliará a condução da coalizão governista ao longo do mandato de Lula. O objetivo será avaliar se o PT obteve sucesso na negociação política com o Congresso durante esse período. Nesse sentido, será concedido maior espaço para a crise do mensalão e, sobretudo, para a reação de Lula - que optou, em resposta, por aumentar o espaço do PMDB e 
do PP em seu ministério. O ex-presidente sobreviveu à crise e, ao final de seus dois mandatos, foi bem-sucedido na formação de ampla coligação eleitoral em torno de sua sucessora.

O quinto capítulo apresentará o primeiro mandato de Dilma Rousseff. Antes mesmo da posse da nova presidente, a correlação de forças dos partidos dentro do ministério foi alterada. Além disso, a demissão de ministros acusados de corrupção desgastou a relação entre a presidente e os membros da coalizão já em 2011. Até meados de 2013, a popularidade de Dilma Rousseff permaneceu elevada, mas entrou em trajetória de queda a partir de então. A reeleição se deu por margem de votos apertada, em meio a ambiente político tensionado entre os aliados.

O sexto capítulo abordará o segundo mandato de Dilma Rousseff, desde a posse até o impeachment. A conturbada relação com o presidente da Câmara, Eduardo Cunha, a crise econômica e o ajuste fiscal e as manifestações nas ruas em meio a uma queda abrupta da popularidade presidencial são o pano de fundo da crise que culminou com seu afastamento do cargo. Somente em outubro de 2015, Dilma Rousseff realizou reforma ministerial de forma a aumentar o espaço dos demais partidos da coalizão. Mas, nesse momento, a Operação LavaJato já se aproximava da presidente, com a prisão do senador Delcídio do Amaral e a posterior condução coercitiva do ex-presidente Lula, inviabilizando qualquer tentativa de reerguimento do governo. O impeachment tornara-se, assim, inevitável.

O sétimo capítulo cuidará de compilar os dados e argumentos apresentados nos capítulos anteriores de modo a responder à questão: por que Dilma Rousseff sofreu impeachment? Em poucas palavras, mesmo tendo iniciado seu governo com coalizão majoritária no Congresso Nacional, Dilma Rousseff não dividiu os ministérios de forma proporcional ao peso dos partidos no Poder Legislativo e empreendeu conflitos constantes com aliados, o que a impossibilitou de ser bem-sucedida na criação de um escudo legislativo. Assim, a presidente não conseguiu sobreviver ao processo de impeachment a que foi submetida, em um contexto de recessão, manifestações e escândalos de corrupção com ampla cobertura por parte da mídia. Ao final, serão apresentadas as conclusões do trabalho. 


\section{REVISÃO DA LITERATURA}

\subsection{DEMOCRACIA NO BRASIL}

O conceito de democracia a ser considerado ao longo do trabalho será, sobretudo, aquele desenvolvido nas obras de Schumpeter (1961), Dahl (1971) e Przeworski (2000). Com base no conceito schumpeteriano de democracia - mecanismo para escolher e autorizar governos por meio da competição entre elites por votos em eleições -, Dahl desenvolve o conceito de poliarquia - sistema inclusivo em que elites políticas competem abertamente por meio de disputas eleitorais periódicas. $\mathrm{O}$ autor admite que os regimes atualmente existentes não são democracias plenas, mas, por meio do conceito da poliarquia, se pode avaliar o quão democráticos eles são. Para Dahl, a democratização deve ser compreendida sob dois eixos, quais sejam, participação e contestação. A existência de diversas minorias políticas realça o caráter poliárquico do regime, compatível com uma sociedade pluralista. Przeworski, por sua vez, enfatiza o aspecto da incerteza da competição eleitoral, ressaltando a importância da aceitação do resultado da eleição por ganhadores e perdedores. O autor afirma que "democracia é o regime em que os incumbentes perdem eleições e deixam o poder se isso acontecer" (PRZEWORSKI, 2000, p.3).

No Brasil, a democracia demorou a se consolidar. Até o final do Estado Novo, as instituições do país pouco se democratizaram (LEAL, 1975). Por sua vez, a República de 1946 - na qual, por quase vinte anos, foram ampliados os direitos políticos dos cidadãos - foi sucedida pelo regime militar de 1964 - em que, por mais de vinte anos, os direitos políticos e as liberdades civis estiveram restritos. A Constituição Federal de 1988 garantiu o retorno à normalidade democrática, com ampliação dos direitos civis, políticos e sociais (CARVALHO, 2001). Em 1989, o eleitor brasileiro pode votar novamente para presidente da República. Atualmente, após mais de trinta anos da transferência do poder político das Forças Armadas para a sociedade civil, a democracia parece sólida - mesmo diante das turbulências que envolveram as eleições de 2018. Neste sentido, observou Kinzo que, "se tomarmos como ponto de referência as duas dimensões de poliarquia propostas por Dahl, o Brasil certamente aprimorou as condições de participação e contestação pública" (KINZO, 2004, p.25). Após a redemocratização, os analfabetos tiveram seu direito de voto garantido e a idade mínima para votar foi reduzida para dezesseis anos. A participação ampliou-se consideravelmente. Ainda, segundo a autora, houve ganhos na contestação pública: 
Desde o restabelecimento do governo civil em 1985, o Brasil confrontou-se com uma sucessão de problemas econômicos e políticos graves, como a hiperinflação, os diversos choques econômicos, as elevadas taxas de desemprego, os escândalos de corrupção de toda sorte e, sobretudo, o impeachment de um presidente. A inexistência de qualquer tentativa de responder a essas crises ultrapassando os limites da ordem constitucional revela uma maior aceitação e, de certa forma, a consolidação das regras democráticas. Além disso, a existência de organizações políticas, sindicatos e movimentos sociais com orientação ideológica ou base social diversas evidencia uma maior tolerância com a oposição (KINZO, 2004, p.26).

De acordo com Kinzo, não obstante a consolidação da democracia, o mesmo não se pode dizer acerca do sistema político-partidário do país:

\begin{abstract}
Desse modo, podemos afirmar com segurança que eleições e democracia estão asseguradas no Brasil. O que dizer, no entanto, da temática relativa aos partidos e ao sistema partidário e sua relação com a consolidação democrática? A esse respeito, contudo, não se pode afirmar que o avanço tenha sido considerável. O cenário partidário aqui delineado - marcado por intensa fragmentação, fragilidade partidária, baixa inteligibilidade da disputa eleitoral e elevada volatilidade eleitoral - são evidências de que, ao longo desses dezoito anos de democracia, os avanços em direção à consolidação do sistema partidário foram bastante modestos (KINZO, 2004, p.35).
\end{abstract}

Nesta visão, a maior fragmentação partidária pode ser atribuída, dentre outros fatores, ao sistema proporcional com lista aberta adotado no Brasil desde a eleição de 1945 (NICOLAU, 2002). Além disso, a Lei Federal $n^{\circ}$ 6.767/1979 instituiu novamente o multipartidarismo no país, contribuindo para um quadro partidário mais fragmentado após a redemocratização.

A imagem de um Poder Legislativo excessivamente fragmentado realçou a necessidade de o chefe do Poder Executivo construir ampla coalizão de partidos, de modo a alcançar a maioria de votos para aprovação de sua agenda e garantir a governabilidade. Ao analisar o modelo político do país, Abranches aponta a especificidade do caso brasileiro:

Não existe, nas liberais-democracias mais estáveis, um só exemplo de associação entre representação proporcional, multipartidarismo e presidencialismo. [...] O Brasil é o único país que, além de combinar a proporcionalidade, o multipartidarismo e o "presidencialismo imperial", organiza o Executivo com base em grandes coalizões. A esse traço peculiar da institucionalidade concreta brasileira chamarei, à falta de melhor nome, "presidencialismo de coalizão" (ABRANCHES, 1988, p.19-22).

O termo cunhado por Abranches será o pano de fundo da análise realizada pelo trabalho.

\title{
2.2 PRESIDENCIALISMO DE COALIZÃO
}

A democracia brasileira vivenciou dois processos de impeachment em curto espaço de tempo. O afastamento de um presidente democraticamente eleito em regime presidencialista não é algo trivial. O conturbado processo de destituição de Dilma Rousseff foi causa para 
muitos debates acerca da viabilidade do presidencialismo no Brasil. Por exemplo, alega-se que a proliferação de partidos políticos e o próprio sistema proporcional com lista aberta prejudicam a governabilidade, tornando impossível a um presidente construir maiorias parlamentares.

Nesse sentido, Lamounier (1992) escreveu acerca da estrutura institucional e da governabilidade na década de 1990, evocando os estudos de democracia desenvolvidos por Lijphart para suas conclusões. Em sua obra, Lijphart estuda a democracia em alguns países e classifica os sistemas políticos em dois modelos, a saber: o modelo majoritário (em que a vontade da maioria deve prevalecer) e o modelo consensual (no qual se busca ampliar a maioria, reduzindo a oposição e os conflitos internos). O modelo majoritário é caracterizado por ser exclusivo e competitivo, enquanto no modelo consensual busca-se a negociação e a concessão. Se, na visão do autor, o sistema consensual é mais democrático, uma vez que se busca aprimorar a qualidade da democracia por meio da obtenção de maiorias qualificadas, as mudanças em países nos quais esse sistema prevalece são mais lentas. Lijphart elenca algumas diferenças entre os sistemas majoritário e consensual, que permitem identificar quais países se enquadram em cada modelo (LIJPHART, 2003).

Com base em Lijphart, Lamounier identifica muitos elementos de democracia consensual no sistema político brasileiro, dentre eles: gabinetes de ampla coalizão, equilíbrio entre os Poderes Executivo e Legislativo, sistema proporcional, multipartidarismo, corporativismo de interesses, forma de Estado federativa, Legislativo bicameral, rigidez constitucional e revisão judicial. Em sua visão, a presença de forte componente consensual dificultaria a governabilidade. O Executivo teria dificuldades de aprovar sua agenda no Legislativo, dados a enorme fragmentação partidária e o alto custo de obter apoio para projetos de seu interesse. Lamounier identifica raízes históricas - que fogem ao escopo deste trabalho que levaram o Brasil a possuir tantos elementos de democracia consensual e assegura:

Não existem, no regime presidencialista, incentivos institucionais para a formação de uma base parlamentar viável (uma maioria estável, ou pelo menos uma minoria substancial, que possa ser acrescida de outros apoios a um custo político razoável) (LAMOUNIER, 1992, p. 45).

Desta forma, para o autor, a combinação entre sistema presidencialista e elementos de democracia consensual seria deletéria e o país necessitaria de reequilíbrio de sua estrutura institucional de modo a permitir a governabilidade.

A literatura é vasta e é possível encontrar vários autores que sustentam a tese oposta: a de que o Legislativo não funciona como veto player da agenda do Executivo e que mesmo a proliferação de partidos não inviabiliza a governabilidade. Figueiredo e Limongi 
desenvolveram a tese acerca das bases institucionais do presidencialismo de coalizão e, na visão deles, as dificuldades mencionadas por Lamounier são passíveis de serem superadas e a projetada ingovernabilidade não se verifica:

A Constituição de 1988 não adotou qualquer das reformas defendidas pelos adeptos da engenharia institucional. O presidencialismo foi mantido, e o plebiscito de 1993 jogou a pá de cal sobre a "opção parlamentarista". Da mesma forma, a legislação eleitoral não sofreu qualquer alteração significativa. O princípio proporcional e a lista aberta continuam a comandar o processo de transformação de votos em cadeiras legislativas. [...] Resultados apresentados neste livro questionam as conclusões e inferências encontradas na literatura comparada e nacional acerca do funcionamento do sistema político brasileiro. Não encontramos indisciplina partidária nem tampouco um Congresso que agisse como um veto player institucional. Os dados mostram, isto sim, forte e marcante preponderância do Executivo sobre um Congresso que se dispõe a cooperar e vota de maneira disciplinada (FIGUEIREDO; LIMONGI, 1999, p. 1920).

Como explicação para esses resultados, os autores recorrem às Constituições escritas pelos militares, que deram preponderância ao Poder Executivo, inclusive por meio do fortalecimento das atribuições legislativas do presidente da República. A Constituição Federal de 1988 manteve parte dessas prerrogativas - como, por exemplo, a edição de medidas provisórias, a iniciativa exclusiva do presidente em matérias orçamentárias e a impossibilidade de o Legislativo aumentar gastos não previstos no Orçamento, dentre outras. Em segundo lugar, a estrutura do Congresso Nacional garante preponderância às respectivas mesas diretoras e aos colégios de líderes na definição da agenda de cada Casa Legislativa. Assim, a definição da pauta, os requisitos de urgência, os encaminhamentos de votação e até mesmo a definição de quais matérias devem ser submetidas à votação nominal cabem, fundamentalmente, aos líderes partidários. Tais mecanismos possibilitam ao chefe do Executivo negociar com os comandos partidários, afastando o risco de negociações individuais com parlamentares. As atribuições legislativas do presidente da República somadas às prerrogativas de líderes partidários na definição da agenda do Congresso Nacional permitem ao Executivo evitar a armadilha da ingovernabilidade. A análise empírica das votações nominais ocorridas no período confirma a teoria desenvolvida pelos autores (FIGUEIREDO; LIMONGI, 1999).

No presidencialismo de coalizão, o presidente da República precisa construir maiorias sólidas no Legislativo. Se o fizer, não deverá encontrar dificuldades para aprovar as medidas de interesse do governo. Para construir a coalizão de partidos que lhe garanta essa maioria, o presidente dispõe de instrumentos valiosos: compõe seu ministério com partidos aliados, distribuindo pastas e garantindo aos partidos papel relevante na formulação de políticas públicas, principalmente. Em contrapartida, esses partidos se comprometem a aprovar os 
projetos do Poder Executivo. Se o presidente for bem-sucedido na formação da coalizão, verá reforçado seu poder de agenda e obterá altas taxas de aprovação de seus projetos no Congresso:

Ao tomar posse, o presidente forma seu governo à maneira de um primeiro-ministro, isto é, distribui ministérios - pastas — para partidos dispostos a apoiá-lo, assegurando assim a formação de uma maioria parlamentar. Formado o governo, portanto, benefícios políticos de toda sorte - influência sobre política, cargos, nomeações de parentes, sinecuras, prestígio etc. — são distribuídos aos membros da coalizão partidária que participa do governo. Em troca, o Executivo espera os votos de que necessita no Parlamento, ameaçando e, se necessário, punindo com a perda dos benefícios recebidos aqueles que não apoiarem a coalizão (FIGUEIREDO; LIMONGI, 1999, p. 33).

Figueiredo e Limongi afirmam ainda que os parlamentares não possuem influência individual sobre o processo decisório e necessitam, pois, agir coletivamente. Há também incentivos para coibir negociações à margem dos comandos partidários: congressistas podem perder cargos em comissões legislativas, sofrer sanções partidárias em suas bases eleitorais e até mesmo perder acesso a recursos dos fundos partidários caso abram dissidência em relação à posição da liderança. Ao mesmo tempo, os líderes partidários devem agir de acordo com a maioria de suas bancadas, sob risco de serem destituídos (FIGUEIREDO; LIMONGI, 1999).

Os autores, enfim, destacam também o papel precioso das medidas provisórias, utilizadas muitas vezes para a implantação de planos econômicos e matérias impopulares e que possuem alto custo de rejeição pelo Parlamento - uma vez que entram em vigor quando de sua edição pelo presidente da República e seus efeitos cessam imediatamente em caso de sua rejeição pelos congressistas (FIGUEIREDO; LIMONGI, 1999).

A conclusão, com base em dados do processo legislativo, é que o presidente consegue aprovar a maior parte de seus projetos e que a maioria das leis é oriunda de projetos iniciados pelo Poder Executivo - que obtém, desta forma, altas taxas de sucesso e de dominância, respectivamente. A nova ordem constitucional, à medida que garantiu atribuições legislativas ao presidente, e os regimentos internos das Casas Legislativas, ao reforçarem os papéis dos líderes na definição da agenda, criaram os instrumentos necessários para o presidencialismo de coalizão funcionar (FIGUEIREDO; LIMONGI, 1999).

\subsection{COALIZÕES NO PARLAMENTARISMO E NO PRESIDENCIALISMO}

Ao contrário do que afirmou Abranches (1988), “o presidencialismo de coalizão, considerado por um bom tempo como um traço peculiar do sistema político brasileiro, é uma realidade frequente nas democracias presidenciais da América Latina, da África e do Leste Europeu” (FREITAS, 2013, p.13). 
Nesse sentido, Cheibub, Przeworski e Saiegh (2004) analisaram as coalizões de governo e o sucesso legislativo no presidencialismo e no parlamentarismo. Os autores utilizaram modelo-padrão de formação de coalizões no parlamentarismo e introduziram algumas modificações, de modo a aplicá-lo ao presidencialismo. As circunstâncias sob as quais se formam as coalizões de governo são semelhantes nos dois sistemas. A principal diferença encontra-se na realização de eleições antecipadas no parlamentarismo, quando o governo perde o apoio da maioria parlamentar. No presidencialismo, não há previsão para eleições antecipadas e governos podem sobreviver mesmo sem apoio legislativo. Por essa razão, governos de coalizão são mais frequentes no parlamentarismo do que no presidencialismo, mas essa seria somente uma diferença de grau e não da essência das coalizões, de acordo com os autores.

Com base em observações nas democracias existentes entre 1946 e 1999, Cheibub, Przeworski e Saiegh chegaram às seguintes conclusões: a) coalizões de governo são frequentes em sistemas presidenciais multipartidários; b) governos de minoria obtêm sucesso na aprovação de suas agendas legislativas e c) os regimes democráticos são mais vulneráveis sob o sistema presidencialista do que sob o sistema parlamentarista, mas isso nada tem que ver com as coalizões. Afirmam os autores:

Até o momento, mostramos que a diferença na frequência das coalizões, embora
favorável ao parlamentarismo, não é grande o suficiente e que a conexão entre as
coalizões e o sucesso legislativo é, no mínimo, duvidosa. Além disso, as democracias
presidenciais são igualmente vulneráveis, independentemente de o governo ser ou não
uma coalizão. Assim, enquanto a observação sobre a vida relativamente curta da
democracia presidencial permanece, a explicação falha. Linz deve estar certo de que
há algo errado com o presidencialismo, mas não temos tido muito sucesso em
descobrir qual de suas tantas explicações é a verdadeira (CHEIBUB; PRZEWORSKI;
SAIEGH, 2004, p. 580, traduçãa nossa).

Assim, não há que se pontuar a existência de coalizões de governo como justificativa para eventuais deformações apresentadas pela democracia brasileira. Coalizões são comuns em muitos sistemas presidencialistas. Além disso, a formação e o gerenciamento das coalizões apresentam muitos aspectos semelhantes no presidencialismo e no parlamentarismo.

Embora Laver e Schofield (1998), em sua obra seminal, tenham estudado a formação de coalizões em países que adotam o sistema parlamentarista de governo, muitas das teses apresentadas por eles podem ser utilizadas também para o caso do presidencialismo brasileiro. Os autores consideram que os partidos políticos, ao participarem de coalizões de governo, podem visar tanto a ocupação de cargos quanto a influência sobre políticas públicas. A decisão dos partidos de participarem da coalizão tem que ver sobretudo com os benefícios futuros que eles esperam obter, visando a obtenção de melhor desempenho eleitoral nos pleitos seguintes. 
Os autores abordam ainda o processo de formação das coalizões, a possibilidade de coalizões de supermaioria ou minoritárias e a estabilidade dos gabinetes.

No que concerne à formação da coalizão, Riker (1962) apresenta o conceito de minimal winning coalition, de acordo com o qual o partido formador (no caso do presidencialismo, o partido do presidente) construirá a coalizão de governo com o tamanho suficiente para garantir o apoio da maioria do Parlamento. A lógica subjacente a esse modelo é que os ganhos obtidos com a coalizão deverão ser divididos entre todos os seus membros, o que desincentiva a formação de coalizões maiores do que o necessário para a obtenção da maioria legislativa.

Em contraposição a esse modelo, Carrubba e Volden (2000) apresentam o conceito de minimal necessary coalition, maior do que a minimal winning coalition. Nesse modelo, os partidos formadores das coalizões buscam criar ambiente mais estável e menos sujeito a custos de defecção. Nesse contexto, Groseclose e Snyder (1996) reafirmam as vantagens das coalizões de supermaioria, sobretudo por impedirem que pequenos partidos atuem como partidos pivôs, dificultando a governabilidade.

Já Axelrod (1970) desenvolve o conceito de minimal connected winning coalition, coalizão mínima vencedora ideologicamente conectada. Ele recorda que o aspecto ideológico pode vir a ser fator importante na formação da coalizão, já que partidos ideologicamente próximos tendem a apresentar menor divergência na implementação de políticas públicas. De Swaan (1973) segue na mesma linha e afirma que as coalizões idelogicamente conectadas terão menos conflitos de interesses entre seus membros.

No que concerne à divisão de poder dentro das coalizões existem duas abordagens distintas. O modelo Baron-Ferejohn (1987) prevê que o partido formador receberá parcela dos postos do gabinete desproporcional ao peso que possui no Legislativo, enquanto os outros parceiros de coalizão receberão retornos proporcionais ao peso dos seus votos no Parlamento. Já o modelo de Morelli e Montero (2003) prevê proporcionalidade total nas recompensas aos partidos da coalizão, incluindo o partido formador ou o partido do presidente. Os autores se baseiam na lei de Gamson (1961), que implica na distribuição de pastas ministeriais entre os partidos da coalizão de modo proporcional à representação desses partidos no Parlamento.

Em suma, as conclusões apresentadas pelos autores acima sobre a formação e o gerenciamento das coalizões no parlamentarismo serão insumos importantes para a análise a ser desenvolvida ao longo do trabalho. De acordo com Cheibub, Przeworski e Saiegh (2004), as coalizões funcionam de modo semelhante no sistema presidencialista - exceção feita à possibilidade de eleições antecipadas. Como visto na seção anterior, Figueiredo e Limongi 
(1999) chegam a afirmar que o presidente forma seu ministério à maneira de um primeiroministro, com partidos dispostos a apoiá-lo, de modo assegurar a maioria parlamentar.

\subsection{GERENCIAMENTO DA COALIZÃO}

Em continuidade ao trabalho desenvolvido por Figueiredo e Limongi (1999), alguns autores trataram de descrever os mecanismos de funcionamento do presidencialismo de coalizão, bem como seus resultados. Em sua abordagem, Freitas (2013) assume que a conclusão desenvolvida pelos autores supracitados de que o Brasil é um país governável é amplamente reconhecida, mas faz ponderação importante:

Mesmo que hoje reconheçamos a governabilidade como um fato, esta parece ser assegurada a despeito do Legislativo, por meio da sua neutralização. O Legislativo tende a ser visto como formado por um amontoado de parlamentares lutando por recursos escassos, cujas demandas são contornadas por um presidente que se ampara em seus poderes constitucionais e nos recursos que controla (FREITAS, 2013, p. 2122).

A autora tenta mostrar que o sistema brasileiro é um presidencialismo de coalizão no sentido estrito do termo. Desta forma, os partidos que participam da coalizão possuem também papel fundamental na formulação de políticas públicas do Executivo:

A coalizão, portanto, não significa ou não deve ser lida como uma restrição ao poder
presidencial, mas sim como a forma que este toma. A coalizão é o que torna este poder
efetivo. A agenda política expressa nas propostas enviadas pelo Executivo deixa de
ser do presidente e passa a ser da coalizão. Dito de outra forma, presidentes formam
coalizões porque antecipam a impossibilidade de aprovar qualquer projeto de lei sem
o concurso de uma maioria (FREITAS, 2013, p.23).

Ela critica a ideia corrente de que os partidos detentores de postos em ministérios estão interessados apenas nas "benesses auferidas a seu partido com a entrada no governo"; argumentando que esses partidos "têm incentivos para se juntar à coalizão também para alcançar seus objetivos em termos de políticas substantivas" (FREITAS, 2013, p.25). Em seu trabalho, a autora analisa os mecanismos que mantêm os partidos unidos e em que medida a agenda da coalizão é compartilhada entre eles.

Amorim Neto (2004) destaca, por sua vez, que o Executivo é o centro de gravidade do sistema político e ressalta a força do presidente da República na estrutura política brasileira:

Tendo o Brasil um sistema de governo sob o qual o presidente, além de contar com a ampla legitimidade e visibilidade que lhe confere a sua eleição pelo povo, detém extensas prerrogativas constitucionais no que concerne à direção da administração pública e ao processo legislativo, é natural que o Poder Executivo seja o centro de gravidade do regime político (AMORIM NETO, 2004, p. 131). 
O autor observa ainda as prerrogativas legislativas do presidente, em linha com o trabalho de Figueiredo e Limongi, além de "amplos poderes sobre a administração pública; [sendo] o principal o que dá ao presidente a faculdade de nomear e demitir livremente os ministros de Estado" (AMORIM NETO, 2004, p. 132). Ele afirma, no entanto, que o presidente precisa compor seu ministério tendo em vista as dimensões partidária e regional. Nesse sentido, pondera que "faceta relevante da formação ministerial é o grau de proporcionalidade agregada entre a percentagem de ministérios detida por cada partido e a contribuição deste, em cadeiras parlamentares, para a base legislativa do governo" (AMORIM NETO, 2004, p. 133).

Em outra obra, Amorim Neto atesta a importância de gabinetes presidenciais serem formados de modo a representar proporcionalmente os partidos com assento no Poder Legislativo. Ele se propõe a desenvolver indicador baseado na distribuição partidária das pastas ministeriais, de modo a avaliar o grau de coalescência dos gabinetes presidenciais. A coalescência é definida como variável contínua: quanto maior a proporcionalidade entre as cotas ministeriais dos partidos e seus pesos parlamentares, mais coalescente será o ministério. $\mathrm{O}$ autor conclui que quanto mais coalescente for o gabinete, mais disciplinado deverá ser o comportamento dos deputados de partidos integrantes do ministério nas votações nominais (AMORIM NETO, 2000).

Em uma abordagem complementar ao trabalho de Figueiredo e Limongi (1999), Silva (2014) ressalta a dominância do Poder Executivo na agenda legislativa brasileira, responsável por $75 \%$ das iniciativas legislativas aprovadas no Congresso Nacional. Ela observa o caráter autorizativo do orçamento do país, cabendo ao Poder Executivo a responsabilidade pela formulação da lei orçamentária. No entanto, na linha da tese desenvolvida por Freitas (2013), a autora afirma que o presidente não governa sozinho; para obter maioria legislativa, há a necessidade de formação de coalizões:

A formação de coalizões tem por base uma troca: os partidos apoiam a agenda legislativa do presidente no Congresso e a formalização do acordo se dá com a ocupação de ministérios na estrutura do Poder Executivo (SILVA, 2014, p.14).

A discussão a que ela se propõe é acerca dos efeitos do compartilhamento entre vários partidos, com foco no Poder Executivo. Como afirmam Martin e Vanberg (2011), os partidos políticos governam juntos, mas disputam eleições separadamente, o que faz com que possuam suas próprias preferências e interesses. Afirma Silva:

O argumento desenvolvido no presente trabalho é o de que em troca do apoio do seu partido no Legislativo, o ministro busca influência no governo. Assim, o presidente e os ministros estão envolvidos em uma troca: apoio legislativo por influência no governo. Com isto em mente, o ministro não pode ser visto como um funcionário 
regular do presidente. [...] Dado que os partidos buscam influência no governo, o objetivo deste trabalho consiste basicamente em identificar como se dá essa influência (SILVA, 2014, p.15).

A autora apresenta modelo que tem por objetivo identificar a influência dos partidos da coalizão nas decisões governamentais. Ela agrupa a influência em dois grupos, quais sejam: a) influência sobre a formulação de políticas e a construção da agenda legislativa e b) influência sobre a implementação de políticas e a alocação de orçamento. A conclusão é que o partido do presidente e aqueles partidos com preferências mais próximas ao partido do presidente terão maior influência na formulação da agenda legislativa. Já em relação à alocação orçamentária, a participação dos parceiros da coalizão é maior (SILVA, 2014).

Bertholini e Pereira (2017), em linha com o argumento desenvolvido por Amorim Neto (2004), afirmam que "presidentes são as figuras centrais no presidencialismo de coalizão. O chefe do Executivo é responsável por decidir os partidos com quem irá governar e de que forma irá alocar os recursos de poder e financeiros disponíveis a esses partidos" (BERTHOLINI; PEREIRA, 2017, p. 529). Os autores analisam os efeitos das estratégias do presidente ao conduzir sua coalizão sobre os custos de governar, partindo da hipótese de que o processo de formação e gerenciamento das coalizões em sistemas presidencialistas multipartidários implica em custos de diferentes ordens para o presidente. Para tanto, eles apresentam Índice de Custo de Governo (ICG), medida que considera as transferências políticas e monetárias feitas pelo presidente aos partidos da coalizão e que permite a comparação entre diferentes governos em diferentes períodos:

O ICG é uma composição da quantidade de ministérios que um presidente decide ter em seu governo, do total de recursos que decide alocar entre os ministérios e do montante em emendas individuais ao orçamento anual de parlamentares que decide executar. O ICG é composto pela 'Quantidade de Ministérios e Secretarias com status de ministério', o 'Logaritmo Natural dos Gastos Totais com Emendas' e o 'Logaritmo Natural dos Gastos Ministeriais Totais’ (BERTHOLINI; PEREIRA, 2017, p. 538).

Após o cálculo do ICG, os autores desenvolvem modelo econométrico para explicar a variação do índice. As variáveis explicativas correspondem às três principais escolhas do presidente ao gerenciar sua coalizão: proporcionalidade, tamanho e heterogeneidade ideológica dos parceiros da coalizão de governo. A variável dependente do modelo é a variação do ICG. A partir dos cálculos, os autores concluem:

Os resultados corroboram de forma enfática as principais hipóteses. Ou seja, quanto mais proporcional for a coalizão, menores os custos de governo; quanto maior for a coalizão, maiores os custos de governo; e quanto mais heterogênea for a coalizão, maiores os custos de governo (BERTHOLINI; PEREIRA, 2017, p. 542). 
Eles afirmam ser intuitivo esperar que maiores custos - representados por ICG mais elevado - se exprimam em maior apoio ao presidente no Congresso, uma vez que o índice considera as transferências políticas e monetárias feitas pelo presidente aos partidos da coalizão; contudo, não é isso que acontece. Como exemplo, os autores mencionam justamente o período de governo de Dilma Rousseff, no qual os custos de governar foram extremamente elevados, sem a contrapartida de apoio no Parlamento. Assim, enfatizam a necessidade de gerenciamento eficiente da coalizão de governo pelo presidente; nesse sentido, coalizões homogêneas, com menos partidos e com divisão proporcional de poder são mais eficientes e menos dispendiosas para o presidente, que obterá resultados melhores com custos mais baixos.

Contudo, a definição acerca dos custos do presidente precisa ser compreendida com cautela. De acordo com os próprios autores:

Podemos nomear de custos de governo o equivalente de toda desutilidade derivada
pelo presidente no processo de gerência da coalizão. Ou seja, todas as transferências
do Executivo para os parceiros, inclusive para o próprio partido do presidente. O
pressuposto básico desse arcabouço teórico é que presidentes maximizam suporte
político no Congresso com um menor custo de gerência possível (BERTHOLINI;
PEREIRA, 2017, p. 534).

Nesse sentido, é preciso considerar que presidentes necessitam fazer concessões a aliados para governar e que as políticas implementadas pelo governo não são exatamente aquelas almejadas pelo chefe do Poder Executivo. Contudo, essa é a essência de um governo de coalizão; transformar isso em conflito ou em custo pode não ser o modo mais adequado de tratar a questão. Além disso, a execução de emendas orçamentárias (que é componente do cálculo do ICG), por exemplo, depende, sobretudo, da situação fiscal do país. Em suma, de acordo com essa visão, quanto menor o gasto público, menores seriam os custos de governar o que é, ao menos, controverso.

\subsection{IMPEACHMENT}

No contexto da discussão sobre a viabilidade de governos no presidencialismo e no parlamentarismo, é preciso analisar as condições políticas para abertura de processo de impeachment. Se, no sistema parlamentarista, a perda de confiança do chefe do governo leva à sua substituição pelo Poder Legislativo; no presidencialismo, o afastamento do presidente está relacionado necessariamente ao cometimento de algum crime.

Em sua obra seminal, Pérez-Liñán (2007) trata o impeachment como uma forma extrema de fracasso presidencial. Os ocupantes do cargo político mais relevante de uma nação podem, 
por meio do processo de impeachment, ser submetidos a julgamentos como qualquer cidadão e, ao final, ser presos ou constrangidos a buscar o exílio. Diferentemente do parlamentarismo, em que a dissolução do Legislativo e a substituição do primeiro-ministro encontram guarida constitucional; no presidencialismo, é mais complexo arbitrar conflitos que envolvam o chefe do Poder Executivo, já que o presidente possui mandato fixo que, em circunstâncias normais, não pode ser abreviado. Por essa razão, Linz (1994) afirma que democracias presidencialistas possuem maiores probabilidades de fracasso do que as democracias parlamentaristas. É nesse contexto que se discute a estabilidade dos regimes democráticos na América Latina.

Pérez-Liñán avalia precisamente a disseminação de processos de impeachment na região a partir da década de 1990 e procura compreender as razões para esse fenômeno. O que torna a sua obra singular e particularmente relevante para esse trabalho é a análise comparada que ele realiza desses processos em diferentes países e circunstâncias, em busca de elementos comuns que possibilitem a identificação das condições políticas que permitem que determinado governante seja destituído do cargo.

Entre 1992 e 2004, seis presidentes latino-americanos foram submetidos a processos de impeachment; o primeiro deles, o brasileiro Fernando Collor de Mello (1992). No entanto, o quadro é mais dramático, uma vez que vários presidentes na região renunciaram, antecipandose a uma possível abertura de processo contra eles. Pérez-Liñán classifica esses episódios como novo padrão de instabilidade presidencial na região. Até a década 1980, o impeachment era um acontecimento pouco comum, enquanto predominavam golpes militares como forma de remover presidentes inconvenientes para elites políticas ou maiorias legislativas. Por isso, o autor afirma:

A América Latina está enfrentando um padrão característico de instabilidade institucional que representa uma ruptura com o passado. Como em décadas anteriores, os governos eleitos democraticamente seguem caindo, mas, diferentemente das décadas anteriores, não se derrubam mais os regimes democráticos (PÉREZ-LIÑÁN, 2007, p.19, tradução nossa).

De certa forma, os militares se afastaram da política latino-americana durante o século XX. O final da Guerra Fria, a mudança da política externa norte-americana e o fortalecimento de organismos multilaterais contribuíram para que soluções políticas por meio de golpes militares se tornassem inaceitáveis. Mas, nem por isso, como se viu, a estabilidade política na região foi alcançada. Embora o regime democrático tenha se estabelecido na maior parte dos países, a interrupção de mandatos presidenciais permanece como fonte de instabilidade: 
resolver suas disputas. O impeachment surgiu como um instrumento poderoso para remover presidentes indesejáveis sem destruir a ordem constitucional (PÉREZ-LIÑÁN, 2007, p. 20, tradução nossa).

O impeachment é apresentado, assim, como um subgrupo, dentro do universo das crises presidenciais - que, por sua vez, são uma forma extremamente hostil de interação entre o Executivo e o Legislativo. Com efeito, em todos os casos analisados, foi preciso que o Poder Legislativo autorizasse a abertura de processo contra o presidente. Por isso, continua o autor:

Esse enfoque parece indicar que o impeachment não é somente um recurso legal para remover do cargo presidentes de quem são encontradas provas de delitos graves; parece ser uma arma institucional que se emprega contra presidentes que enfrentam um Legislativo beligerante (PEREZ-LIÑAN, 2007, p. 29, tradução nossa).

Ele passa, então, a considerar as condições para que o impeachment aconteça. A condição fundamental é que existam manifestações populares contra um presidente impopular. Tais manifestações podem ser fruto de um desempenho econômico ruim, mas, quase sempre, estão relacionadas à eclosão de escândalos de corrupção envolvendo o presidente ou seu gabinete, com ampla cobertura por parte da mídia. Pérez-Liñán destaca, sobretudo, o papel desempenhado pelos meios de comunicação na disseminação dos escândalos de corrupção. Em relação ao papel desempenhado pelo Poder Legislativo, afirma o autor:

As manifestações populares - mais que a ação legislativa - parecem ser a força principal que impulsiona a queda dos governos eleitos. A ação do Congresso provê o marco - o melhor marco possível - para a derrubada do governo, mas parece desempenhar um papel meramente reativo (PÉREZ-LIÑÁN, 2007, p. 326, tradução nossa).

O Poder Legislativo, entretanto, cumpre papel fundamental para o andamento ou não do processo. O Congresso pode desprezar as evidências de crime de responsabilidade, mesmo diante de manifestações populares contra o presidente; nesse caso, pode se falar na construção de um escudo legislativo que blinda o presidente diante das ameaças ao seu mandato. Por outro lado, o impeachment pode ser empregado contra um presidente que enfrenta um Legislativo hostil ou que adota estratégia de isolamento em relação ao Congresso, mesmo que as evidências de crime não estejam devidamente demonstradas. Em suma, "o modelo de relações entre o Executivo e o Legislativo que o presidente estabelece no início do seu mandato, pode determinar a disposição dos legisladores de proteger o Executivo de um impeachment em um momento posterior" (PÉREZ-LIÑÁN, 2007, p. 267, tradução nossa). É nesse contexto que a interação entre o chefe do Poder Executivo e a coalizão de governo assume a sua importância.

Ao analisar o papel exercido pelo Congresso Nacional seria plausível associar o processo de impeachment ao voto de desconfiança, presente nos sistemas parlamentares. No entanto, Pérez-Liñán rechaça essa argumentação, classificando o impeachment como uma 
catástrofe política e não como um mero realinhamento partidário. Se, no sistema parlamentarista, a perda de confiança do chefe do governo leva à sua substituição pelo Poder Legislativo; no presidencialismo, o afastamento do presidente está relacionado ao cometimento de crime. Afirma o autor:

Consideraremos, como experimento mental, as expectativas profissionais de um primeiro-ministro que recebeu um voto de desconfiança comparativamente às de um presidente submetido a um processo de impeachment: o primeiro pode regressar à sede central de seu partido e preparar-se para as próximas eleições; o segundo abandona o país em busca de um refúgio seguro para escrever suas amargas memórias (PÉREZLIÑÁN, 2007, p. 326, tradução nossa).

Na conclusão de sua obra, Pérez-Liñán afirma que "o processo de impeachment surgiu como uma forma mais efetiva de abordar a queda de um governo eleito, protegendo ao mesmo tempo uma Constituição democrática, mas, geralmente, não conseguiu evitar um novo ciclo de predomínio presidencial e queda do governo" (PÉREZ-LIÑÁN, 2007, p. 337, tradução nossa). Em outro trecho, ele enquadra o processo de impeachment como um modelo de responsabilidade espasmódica no qual "os controles institucionais se ativam somente quando um governo já caiu em desgraça. O resultado paradoxal são legislativos latino-americanos com capacidade provada de castigar as faltas presidenciais, mas sem capacidade para evitá-las" (PÉREZ-LIÑÁN, 2007, p.36, tradução nossa).

Em suma, o processo de impeachment de Dilma Rousseff encaixa-se perfeitamente na teoria desenvolvida por Pérez-Liñán, como se verá adiante, sobretudo na relação que ela desenvolveu com o Poder Legislativo durante o seu mandato presidencial.

\subsection{METODOLOGIA}

Conforme já foi mencionado, pretende-se analisar a relação da presidente Dilma Rousseff com sua base de sustentação no Congresso Nacional ao longo do seu mandato. A presidente da República foi afastada por meio de processo de impeachment, que não aconteceria sem adesão de ao menos dois terços dos parlamentares da Câmara dos Deputados e do Senado Federal. Assim, será preciso avaliar, com base na revisão da literatura realizada, o gerenciamento da coalizão pela presidente, de modo a identificar possíveis explicações para a erosão do apoio ao governo no Legislativo.

Como forma de estimar o apoio ao governo no Congresso Nacional serão utilizados os dados disponibilizados pelo Banco de Dados do CEBRAP (Centro Brasileiro de Análise e Planejamento), que possibilitam medir o apoio dos parlamentares ao governo e acompanhar 
como eles se posicionaram nas votações legislativas realizadas de forma nominal. Além de avaliar a evolução do apoio aos projetos de interesse do governo ao longo do tempo em ambas as Casas, será possível também avaliar a evolução do apoio em cada partido aliado.

Além da descrição de eventos que evidenciem a existência de conflito perene entre a presidente e sua coalizão de governo, será avaliada a composição dos gabinetes ministeriais durante o mandato de Dilma Rousseff, de modo a verificar se houve concentração de poder nas mãos do partido da presidente e se os partidos aliados estiveram sub-representados. Nesse aspecto, será preciso decidir a melhor forma de medir o compartilhamento de poder entre os partidos da coalizão no gabinete ministerial; será analisada a divisão de poder do ponto de vista da alocação orçamentária.

É preciso considerar que nem todas as pastas têm a mesma relevância. Avaliar a participação dos partidos no ministério pelo número de ministros que possuem não parece ser o critério mais adequado. Uma alternativa seria avaliar as dotações orçamentárias controladas pelos partidos por meio de seus ministros. No entanto, também esse dado pode trazer distorções. Há pastas com orçamentos elevados, mas cujos desembolsos estão comprometidos com despesas obrigatórias, restando pouco espaço para investimentos - que trazem maior visibilidade, podendo suscitar ganhos políticos aos agentes e partidos envolvidos. Assim, a variável mais conveniente parece ser o orçamento total de investimento que os partidos conseguem empenhar por meio dos ministros indicados por eles para compor o Gabinete. Esses dados são disponibilizados pelo SIAFI (Sistema Integrado de Administração Financeira do Governo Federal).

É bem verdade que os ministérios geralmente não são concedidos aos partidos aliados de "porteira fechada", isto é, muitas vezes, a gestão de determinada pasta é compartilhada por diferentes partidos. No entanto, a tarefa de identificar a gestão compartilhada em ministérios é inviável. Praça, Freitas e Hoepers (2011) desenvolveram importante trabalho sobre indicações políticas para cargos comissionados - cargos de direção e assessoramento superiores (DAS) e a condução da coalizão durante o segundo governo Lula, mas os dados disponíveis ainda são escassos e, muitas vezes, pouco confiáveis. Por isso, não será possível a sua utilização.

Em razão da estrutura de governo existente no país, também parece importante incluir na análise, de forma complementar, os dados de investimentos de algumas empresas estatais cujos dirigentes obtiveram suas nomeações pela indicação de partidos políticos integrantes da coalizão. Contudo, a identificação de indicações políticas em empresas estatais é tarefa mais difícil que no caso dos ministérios. Além disso, no caso da Petrobrás, por exemplo, é sabido que a diretoria da empresa foi partilhada por PT, PMDB e PP. Assim, apesar de a empresa ter 
sido presidida por indicados do PT, não se pode assumir que somente o partido se beneficiou politicamente dos investimentos da estatal. Também não se considerará no trabalho os recursos oriundos de corrupção que os partidos políticos eventualmente tenham recebido por meio da participação na gestão de empresas estatais. As investigações ainda estão em curso e, ademais, não há que se relacionar o presidencialismo de coalizão com a corrupção existente na administração pública brasileira.

Por fim, pesquisa realizada pela Universidade de Oxford, pela Fundação Getúlio Vargas e pela Universidade Federal de Pernambuco $^{2}$ revelou, por meio de entrevistas com parlamentares, os ministérios mais cobiçados no Congresso Nacional. Entretanto, o estudo foi publicado somente em 2018 e não há indicativos de que essas preferências sejam as mesmas do início do governo Dilma Rousseff. Novas pastas foram criadas, novos projetos tiveram início e, possivelmente, algumas políticas públicas deixaram de ser prioritárias, sendo substituídas por outras.

Em suma, o trabalho avaliará o orçamento de investimento que os partidos, por meio de ministros indicados - e, também, em alguns casos, por meio de dirigentes de empresas estatais -, conseguiram empenhar como principal variável para medir o compartilhamento do poder com os membros da coalizão. Além disso, serão expostos eventos que confirmam a existência de conflitos entre a presidente e os partidos aliados. Em contrapartida, por meio dos dados do CEBRAP, será possível avaliar o comprometimento dos partidos da coalizão com a agenda do governo no Congresso Nacional.

\footnotetext{
${ }^{2}$ Os ministérios mais cobiçados pelos políticos do Brasil, segundo pesquisa inédita de Oxford. Disponível em: http://www.bbc.com/portuguese/brasil-43218087
} 


\section{APRESENTAÇÃO DO TEMA}

A tese segundo a qual o Brasil é um país governável foi corroborada pelos fatos. Fernando Henrique Cardoso e Luiz Inácio Lula da Silva governaram o país de 1995 até 2010 e conseguiram aprovar grande parte da agenda priorizada por seus respectivos governos. Conforme pode ser observado nas figuras 1 e 2, abaixo, os governos obtiveram taxas expressivas de apoio entre os partidos da coalizão nas votações nominais ocorridas no período.

Figura 1. Apoio ao Governo na Câmara dos Deputados - Partidos da Coalizão. Governo FHC.

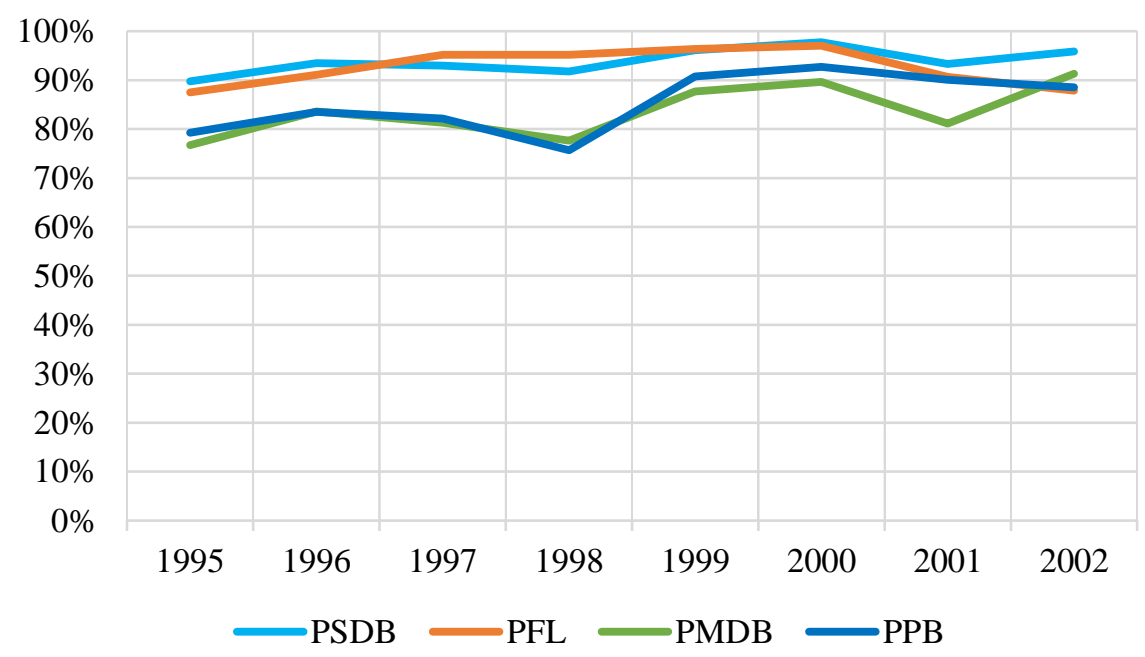

Fonte: Banco de dados do CEBRAP.

Figura 2. Apoio ao Governo na Câmara dos Deputados - Partidos da Coalizão. Governo Lula.

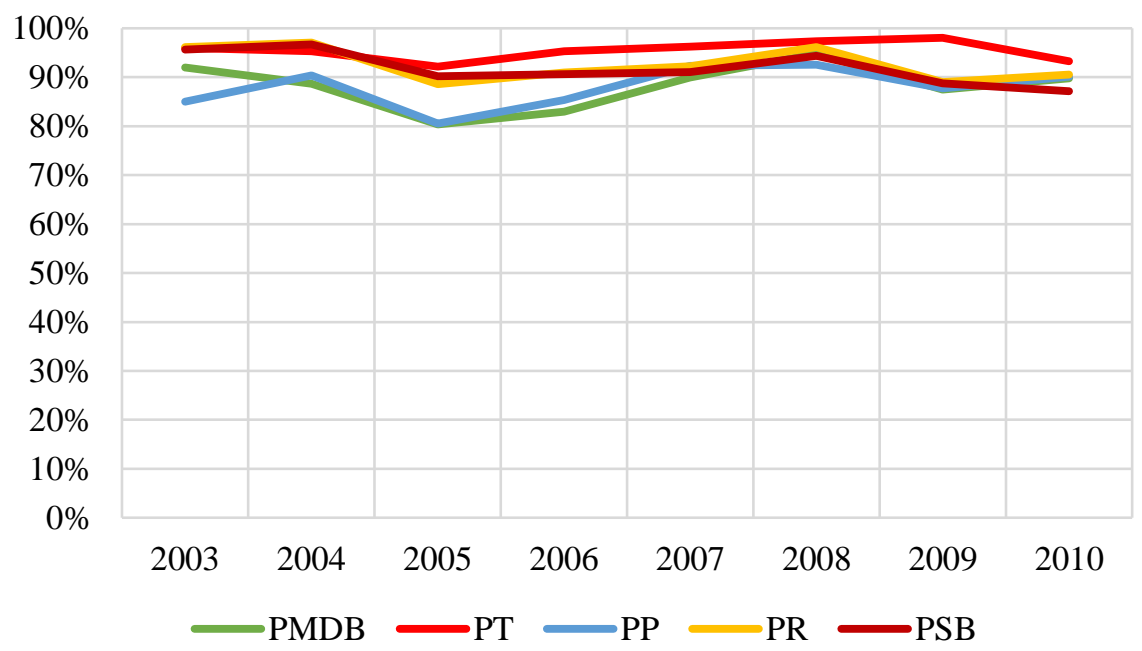

Fonte: Banco de dados do CEBRAP. 
No entanto, a crise política vivenciada pelo Brasil a partir de 2015, que culminou com o impeachment da presidente Dilma Rousseff em 2016, fez ressurgir o debate sobre o sistema político brasileiro e sua viabilidade. Figueiredo e Limongi constatam que o presidencialismo de coalizão passou a ser criticado e responsabilizado pela crise:

\begin{abstract}
A montagem da coalizão tende a ser vista como um ato de "compra", um pagamento feito pelo chefe do Executivo para obter a governabilidade, pagamento que teria como consequência o desvirtuamento do programa de governo. O modelo estaria na raiz da atual crise, e esta apenas evidenciaria que o modelo teria encontrado seus limites, que somente com o abandono do presidencialismo de coalizão ou, no mínimo, com sua transformação radical, seria possível sair do buraco em que o país se meteu (FIGUEIREDO; LIMONGI, 2017, p. 80-81).
\end{abstract}

De fato, na última legislatura, o Congresso Nacional discutiu a reforma política e debateu a adoção do voto majoritário para a Câmara dos Deputados. Além disso, foi aprovada cláusula de desempenho para a eleição de representantes no Legislativo (Emenda Constitucional $\mathrm{N}^{\mathrm{o}}$ 97, de 2017). O próprio sistema presidencialista foi questionado, com o debate sobre a adoção do sistema semipresidencialista, aos moldes do existente na França. Não se pretende discutir as vantagens e desvantagens das alternativas mencionadas. Todavia, é preciso reconhecer que as propostas tiveram por alvo os elementos do presidencialismo de coalizão - voto proporcional, multipartidarismo, sistema presidencialista.

Figueiredo e Limongi ressalvam que "pilhar o Estado é uma estratégia compatível apenas com perspectivas de curtíssimo prazo, um horizonte temporal que não compreende o próximo ciclo eleitoral" (FIGUEIREDO; LIMONGI, 2017, p. 85). Políticos buscam a vitória em eleições e, para tanto, não procuram somente cargos, mas também influência sobre políticas públicas (LAVER; SCHOFIELD, 1998). Além disso, é bem possível que a raiz da crise não esteja no sistema político. Abranches, que definiu o termo presidencialismo de coalizão e se tornou um de seus críticos, faz ponderação importante:

O problema não está, portanto, na relação entre Executivo e Legislativo que o presidencialismo de coalizão determina. Está na relação entre partidos e eleitores, que não está também associada às regras eleitorais, mas no nível de desenvolvimento cívico do eleitorado, entre outras coisas (ABRANCHES, 2001, p. 269).

A análise a ser desenvolvida pretende evidenciar a funcionalidade do presidencialismo de coalizão, desde que o governo formado e a agenda apresentada pelo chefe do Poder Executivo sejam compartilhados com a coalizão de governo. Como afirmam Figueiredo e Limongi: "poderes de agenda [...] não substituem a maioria, não permitem passar por cima do Congresso" (FIGUEIREDO; LIMONGI, 2017, p. 86). Na mesma linha, Freitas considera que 
"a agenda política expressa nas propostas enviadas pelo Executivo deixa de ser do presidente e passa a ser da coalizão" (FREITAS, 2013, p.23).

Nesse contexto, Amorim Neto (2004) ressalta a importância de gabinetes presidenciais representarem de forma proporcional os partidos com assento no Poder Legislativo e Bertholini e Pereira (2017) afirmam que coalizões com menos partidos, baixa heterogeneidade ideológica e alocação proporcional de poder entre seus membros devem proporcionar menores custos e maior estabilidade aos governos.

No governo Fernando Henrique Cardoso, a coalizão de governo era formada por menos partidos e menor heterogeneidade ideológica entre os seus membros. Já no governo Lula, o número de partidos participantes da coalizão aumentou, bem como a dispersão ideológica entre eles. Tal fato pode ser explicado em razão de o PT ser um partido de centro-esquerda, que assumiu a presidência em um contex to de um Congresso majoritariamente formado por partidos de centro ou de direita. Entretanto, tanto FHC quanto Lula conseguiram aprovar boa parte das agendas apresentadas ao Congresso. A coalizão de governo de Dilma Rousseff é semelhante à coalizão existente durante o governo Lula: muitos partidos, com elevada dispersão ideológica entre eles. O destino de Dilma Rousseff, no entanto, foi diferente de seu antecessor. A tabela 1 expõe as coalizões de governo formadas durante esse período.

Tabela 1. Coalizões de governo durante o período 1995-2016.

\begin{tabular}{|c|c|c|c|c|}
\hline Governo & $\begin{array}{c}\text { Partido } \\
\text { formador }\end{array}$ & Partidos da coalizão & Período & Evolução da coalizão \\
\hline FHC I & PSDB & PSDB-PFL-PMDB-PTB & 1995 & Formação da coalizão \\
\hline FHC I & PSDB & PSDB-PFL-PMDB-PTB-PPB & $1996-1998$ & Entra PPB \\
\hline FHC II & PSDB & PSDB-PFL-PMDB-PPB & 1999-2001 & $\begin{array}{c}\text { Formação da coalizão. } \\
\text { Sai PTB } \\
\end{array}$ \\
\hline FHC II & PSDB & PSDB-PMDB-PPB & 2002 & Sai PFL \\
\hline Lula I & PT & $\begin{array}{c}\text { PT-PL-PCdoB-PSB-PTB-PPS-PV- } \\
\text { PDT }\end{array}$ & 2003 & Formação da coalizão \\
\hline Lula I & PT & $\begin{array}{c}\text { PT-PL-PCdoB-PSB-PTB-PPS-PV- } \\
\text { PMDB }\end{array}$ & 2004 & Sai PDT. Entra PMDB. \\
\hline Lula I & PT & $\begin{array}{l}\text { PT-PL-PCdoB-PSB-PTB-PMDB- } \\
\text { PP }\end{array}$ & 2005-2006 & Saem PPS e PV. Entra PP. \\
\hline Lula II & PT & $\begin{array}{l}\text { PT-PR-PCdoB-PSB-PTB-PMDB- } \\
\text { PP-PDT-PRB }\end{array}$ & $2007-2010$ & $\begin{array}{l}\text { Formação da coalizão. } \\
\text { Entram PDT e PRB }\end{array}$ \\
\hline Dilma I & PT & $\begin{array}{c}\text { PT-PR-PCdoB-PSB-PMDB-PP- } \\
\text { PDT-PRB }\end{array}$ & 2011-2012 & $\begin{array}{l}\text { Formação da coalizão. } \\
\text { Sai PTB. }\end{array}$ \\
\hline Dilma I & PT & $\begin{array}{l}\text { PT-PR-PCdoB-PSB-PMDB-PP- } \\
\text { PDT-PRB-PSD } \\
\end{array}$ & 2013 & Entra PSD \\
\hline Dilma I & PT & $\begin{array}{l}\text { PT-PR-PCdoB-PMDB-PP-PDT- } \\
\text { PRB-PSD-PROS }\end{array}$ & 2014 & Sai PSB. Entra PROS. \\
\hline Dilma II & PT & $\begin{array}{l}\text { PT-PR-PCdoB-PMDB-PP-PDT- } \\
\text { PRB-PSD-PROS }\end{array}$ & 2015-2016 & Formação da coalizão \\
\hline
\end{tabular}

Fonte: Elaboração própria, com base em dados do CEBRAP. 
Pereira relaciona o insucesso do governo Dilma Rousseff ao modelo de coalizão adotado pelo PT. Na visão do autor, o PT formou coalizões com muitos partidos e de posições ideológicas muito diferentes; além disso, o partido preferiu acomodar suas alas internas a compartilhar o poder com partidos aliados. Afirma o autor:

O PT gerencia de forma ruim suas coalizões. O PT, tradicionalmente, desde quando
Lula assumiu a Presidência, preferiu construir coalizões com número grande de
parceiros, muito heterogêneos. Eles não têm uma plataforma comum de ação. É difícil
coordenar uma coalizão dessas, e o PT ainda tem optado por não compartilhar poder
com os parceiros, numa postura monopolista de concentração de poder. Lula alocou
$60 \%$ dos 35 ministérios no começo de seu governo nas mãos do PT. Seu principal
parceiro, o PMDB, só tinha dois ministérios. Depois, conseguiu ampliar, mas
continuou subcompensado. O governo Dilma continuou com uma coalizão grande
demais, heterogênea e monopolista. Isso gera tensões e animosidades internas [...].
Existe, no âmago do PT, uma dificuldade de entender que é necessário compartilhar
poder para que o presidencialismo de coalizão funcione bem. O PT, diferentemente
de outras siglas brasileiras, tem muitas facções. Parece muito o partido peronista
argentino. Tem vários grupos que funcionam como partidos dentro do PT. O PT
prefere ser proporcional com as facções internas e desproporcional com os parceiros
externos da coalizão. (PEREIRA, 2014).

Nesse sentido, a comparação da divisão dos ministérios entre os partidos da coalizão durante os governos Lula e Dilma Rousseff parece adequada. Não se pode deixar de considerar que Lula concluiu seu mandato com amplo apoio do Congresso Nacional. É fato que, nos governos do PT, o partido do presidente foi mais contemplado que durante os governos de Fernando Henrique Cardoso, como afirma o autor. Também é evidente que, por ser um partido de centro-esquerda, o PT precisou construir alianças heterogêneas, em um Congresso mais fragmentado e formado predominantemente por partidos mais conservadores. Não se pode desprezar também que Lula enfrentou dificuldades para formar a sua coalizão. Em seu primeiro mandato, ele iniciou o governo com base de apoio minoritária. Além disso, o PT foi derrotado na eleição para presidência da Câmara em 2005, ano em que eclodiu o escândalo do mensalão, e o afastamento do presidente da República chegou a ser cogitado.

Contudo, como forma de superar a crise, Lula aumentou o espaço de partidos aliados, sobretudo do PMDB e do PP, em seu governo. A partir de 2007, o PMDB se tornou o principal parceiro do PT na coalizão governista e conquistou o comando dos ministérios da Saúde e da Integração Nacional - pastas com orçamentos importantes -, além da garantia de rodízio com o PT para ocupar a presidência da Câmara dos Deputados. Nas eleições de 2010, os peemedebistas indicaram o presidente nacional do partido para compor a chapa presidencial ao lado do PT. Em contrapartida, os petistas apoiaram candidaturas do PMDB aos governos de Minas Gerais e do Rio de Janeiro. Dessa forma, não obstante as colocações de Pereira sobre a 
natureza das coalizões nos governos do PT, não parece haver crise entre os aliados no segundo mandato de Lula.

É preciso, assim, investigar o gerenciamento da coalizão durante o governo de Dilma Rousseff. Já em seu primeiro gabinete, a presidente retirou do PMDB os ministérios da Saúde e da Integração Nacional. Além disso, há episódios de atrito entre a presidente e seu próprio partido já no início do governo, como se verá ao longo do trabalho. É preciso enfatizar que a coalizão de governo de Dilma Rousseff, desde a sua posse, reunia a ampla maioria do Congresso Nacional. Tanto Fernando Henrique Cardoso quanto Luiz Inácio Lula da Silva tiveram que articular a construção de maioria congressual ao longo de seus mandatos. Nesse sentido, FHC encontrou dificuldades para aprovar as reformas constitucionais a que se dispôs e Lula encontrou percalços para a formação de coalizão majoritária no Parlamento, com a eclosão do escândalo do mensalão, como descrito acima. Por outro lado, ambos os presidentes conseguiram, superadas as dificuldades, governar com o apoio legislativo até a conclusão dos seus mandatos. Fernando Collor, por sua vez, foi eleito sem base congressual, não conseguiu construir coalizão de governo que reunisse maioria parlamentar e acabou afastado da presidência da República. Já Dilma Rousseff, mesmo diante da circunstância favorável de contar com maioria legislativa desde o início de seu governo, teve o mesmo destino de Collor.

Conforme pode ser observado na figura 3 , abaixo, o apoio ao governo diminui em todos os partidos aliados ao longo do governo Dilma Rousseff. A queda é contínua e ocorre até mesmo no partido da presidente, o PT.

Figura 3. Apoio ao Governo na Câmara dos Deputados - Partidos da Coalizão. Governo Dilma.

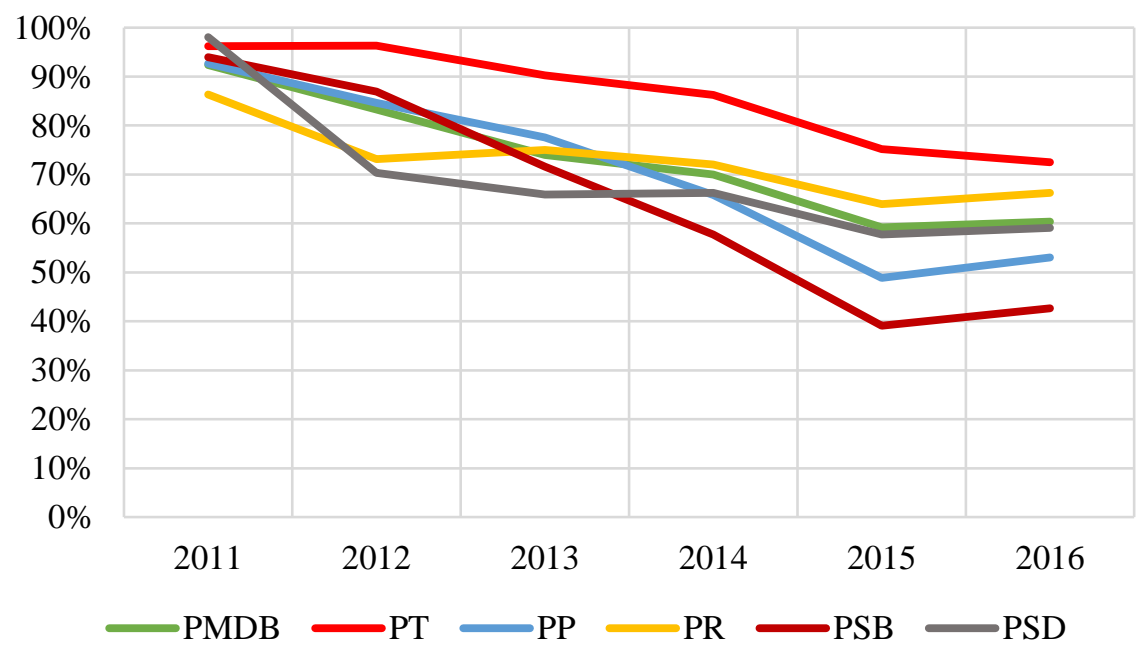

Fonte: Banco de dados do CEBRAP. 
Como já foi mencionado na revisão da literatura, o processo de impeachment depende de uma série de condições políticas para se realizar. O ritmo mais lento da economia do país e a eclosão de escândalos de corrupção com ampla cobertura da mídia foram ingredientes fundamentais para a queda de popularidade presidencial e para a realização de manifestações populares contra o governo. Na ausência dessas variáveis, uma articulação política falha não seria condição suficiente para a destituição de um presidente. No entanto, na presença dessas variáveis, somente o apoio consistente do Poder Legislativo poderia salvar o chefe do Executivo do processo de impeachment.

Nas palavras de Pérez Liñán (2007), a construção de um escudo legislativo poderia evitar o afastamento presidencial. Conforme visto acima, contudo, os partidos da coalizão afastaram-se gradualmente da presidente. Ou, dito de outra forma, Dilma Rousseff afastou-se, ano após ano, de sua base de apoio. Nessas condições, dificilmente a presidente sobreviveria a um processo de afastamento. Quando a sua situação se tornou dramática, a partir de 2015, com manifestações nas ruas e o avanço da Operação Lava-Jato, a base legislativa do governo ruiu em curto espaço de tempo. Em suma, Dilma Rousseff não conseguiu construir escudo legislativo de forma a assegurar a sua permanência no cargo. Nos capítulos seguintes, serão expostas possíveis explicações para o comportamento do Poder Legislativo no período, sobretudo uma relação conflituosa da presidente com seus aliados e uma divisão desproporcional do ministério entre os partidos membros da coalizão. 


\section{O PT NA PRESIDÊNCIA: APRENDENDO A DIVIDIR O PODER SOB LULA}

Luiz Inácio Lula da Silva (PT) elegeu-se presidente da República em 2002, derrotando o candidato do governo, José Serra (PSDB), com 61\% dos votos no segundo turno. A eleição de Lula alçou o PT ao poder e marcou a ascensão de um partido de esquerda ao governo brasileiro pela primeira vez desde a redemocratização. O petista, ex-metalúrgico, já havia tentado a presidência em outras três ocasiões - em 1989 perdeu para Fernando Collor (PRN) e em 1994 e 1998 perdeu para Fernando Henrique Cardoso (PSDB).

Em 2002, Lula candidatou-se com o apoio de uma coligação formada por PT, PL, PCdoB, PCB e PMN. O PL (que posteriormente deu origem ao PR) indicou o senador e empresário José Alencar (PL-MG) para o cargo de vice-presidente. $\mathrm{O}$ acordo foi conduzido por José Dirceu, presidente do PT, e Valdemar Costa Neto, presidente do PL ${ }^{3}$. No segundo turno da eleição, Lula obteve apoios importantes. Além dos presidenciáveis derrotados no primeiro turno da eleição ${ }^{4}$, Ciro Gomes (PPS) e Anthony Garotinho (PSB), também declararam voto no petista a ex-governadora Roseana Sarney (PFL), que desistiu da candidatura presidencial, o expresidente da República José Sarney (PMDB) ${ }^{5}$ e o ex-presidente do Senado Antônio Carlos Magalhães (PFL) ${ }^{6}$. Pela diversidade de apoios recebidos, é possível constatar que Lula foi bemsucedido na tarefa de diminuir sua taxa de rejeição e afastar os temores de que faria um governo excessivamente voltado à esquerda.

Nas eleições legislativas de 2002, o PT conquistou 91 cadeiras na Câmara dos Deputados - o PL elegeu 26 deputados e o PCdoB elegeu 12. Além disso, o PSB, o PPS, o PTB e o PDT - que apoiaram Lula no segundo turno - elegeram 84 deputados. Conforme a expectativa, esses partidos compuseram posteriormente a coalizão governista no Congresso Nacional, a partir da posse do novo presidente. Contudo, mesmo com todos esses apoios, a coalizão de Lula ficou distante de alcançar a maioria congressual.

Por outro lado, os principais partidos que deram sustentação ao governo de Fernando Henrique Cardoso (PSDB, PFL e PPB) optaram por não aderir ao governo petista - embora a ala do PFL ligada aos senadores eleitos Antônio Carlos Magalhães e Roseana Sarney tivesse

\footnotetext{
${ }^{3}$ Negociação PT-PL avança e já inclui programa de governo. Disponível em: https://www1.folha.uol.com.br/fsp/brasil/fc1402200206.htm

${ }^{4}$ Especial Lula: um governo de alianças. Disponível em: https://www.dgabc.com.br/Noticia/286989/especial-lula-um-governo-de-aliancas

${ }^{5}$ Sarney declara apoio à candidatura Lula já no $1^{\circ}$ turno. Disponível em: https://noticias.uol.com.br/inter/reuters/2002/08/27/ult27u25290.jhtm

${ }^{6}$ ACM declara voto em Lula no $2^{\circ}$ turno. Disponível em: https://www1.folha.uol.com.br/fsp/brasil/fc0810200226.htm
} 
declarado voto em Lula no segundo turno. A dúvida, dessa forma, era acerca do posicionamento político do PMDB que, não obstante ter apoiado formalmente o PSDB na eleição, sempre foi marcado por importantes divergências internas.

Por essa razão, José Dirceu tratou de negociar aliança para que o PMDB participasse da coalizão governista, o que permitiria ao governo petista alcançar a almejada maioria parlamentar. As tratativas entre Dirceu e Michel Temer, presidente nacional do PMDB, avançaram durante o mês de dezembro. Nesse período, chegou a ser anunciado acordo pelo qual os peemedebistas seriam contemplados com os ministérios das Minas e Energia e da Integração Nacional. A negociação, contudo, foi surpreendentemente desautorizada por Lula ${ }^{7}$.

Na composição ministerial final anunciada pelo presidente ${ }^{8}$, o PT ficou com as pastas da Casa Civil e da Fazenda, com José Dirceu e Antônio Palocci, respectivamente - os dois homens-fortes do governo. O partido do presidente obteve ainda pastas com orçamentos significativos, como Educação, Saúde e Cidades - além das Minas e Energia, para a qual foi nomeada Dilma Rousseff, ex-secretária de Olívio Dutra no governo gaúcho. O ministério das Cidades foi criado por Lula e, com o passar do tempo, tornou-se uma das pastas mais cobiçadas pelos partidos. O PL, partido do vice-presidente José Alencar, ficou com a pasta dos Transportes, também com orçamento relevante. Além disso, foram contemplados no ministério o PSB, o PPS, o PDT, o PTB e o PCdoB. A coalizão governista, com tais apoios, não alcançou a maioria legislativa. Lula optou por formalizar uma coalizão menor e conceder mais espaço ao PT em seu primeiro ministério. A rejeição ao acordo com o PMDB viria a ter consequências importantes, como se verá ao longo do capítulo.

Na eleição para as Mesas Diretoras no Congresso Nacional em fevereiro de 2003, o governo optou pelo pragmatismo. O PT, maior bancada da Câmara, ficou com a presidência da Casa - o indicado do partido foi João Paulo Cunha. No Senado, o PMDB, a maior bancada, indicou o ex-presidente José Sarney para a presidência.

Em relação à política econômica, Lula nomeou para o Banco Central Henrique Meirelles, ex-presidente do BankBoston e deputado federal eleito pelo PSDB - ao aceitar o cargo, ele se desfiliou do partido e renunciou ao mandato parlamentar. O presidente também se comprometeu em aprovar a reforma da previdência, fixando novas regras para a aposentadoria do setor público. Lula foi pessoalmente ao Congresso Nacional entregar a proposta para a

\footnotetext{
${ }^{7}$ PMDB fica fora do ministério do governo Lula. Disponível em: https://noticias.uol.com.br/inter/reuters/2002/12/20/ult27u29752.jhtm

${ }^{8}$ Lula anuncia nomes que vão compor seu ministério. Disponível em: https://www1.folha.uol.com.br/folha/brasil/ult96u43892.shtml
} 
reforma previdenciária ${ }^{9}$ - que, em razão de alterar regras previstas na Constituição, necessitou maioria qualificada de três quintos e votação em dois turnos em cada Casa Legislativa.

Mesmo com apoio de uma coalizão de governo minoritária, Lula foi bem-sucedido na aprovação da reforma. O PT fechou questão sobre o tema e abriu processo para expulsar os parlamentares que votaram contra o projeto. Da mesma forma, a oposição - que apoiou medidas semelhantes durante o governo FHC - se dividiu e cerca de metade das bancadas do PSDB e do PFL votou favoravelmente à matéria. No mês de agosto, a Câmara dos Deputados aprovou o texto principal da reforma em dois turnos, com 358 votos na primeira votação e 357 votos na segunda. O Senado concluiu a votação em dezembro, com 55 e 51 votos nas duas votações necessárias ${ }^{10}$. A aprovação da matéria custou ao governo o apoio do PDT, que deixou a base aliada e perdeu a pasta das Comunicações, e a expulsão de dissidentes do $\mathrm{PT}^{11}$.

Embora a coalizão governista contemplasse a minoria do Congresso no início de 2003, a situação já havia se modificado de modo favorável ao governo ao final do ano - cerca de cinquenta parlamentares trocaram de legenda ${ }^{12}$. As maiores defecções se deram às custas de siglas de oposição; já o PTB, o PL e o PP foram os partidos que mais se beneficiaram com as mudanças. Ainda assim, em janeiro de 2004, Lula anunciou reforma ministerial ${ }^{13}$ : nomeou o líder do PMDB na Câmara, Eunício Oliveira, para a pasta de Comunicações e o senador Amir Lando, também do PMDB, para o ministério da Previdência Social. Para a presidência da Eletrobrás foi nomeado Silas Rondeau, aliado do senador José Sarney. A negociação com o PMDB, contudo, não foi realizada com a presidência nacional do partido, mas com as bancadas no Congresso Nacional ${ }^{14}$. É importante mencionar que o ingresso do PMDB no primeiro escalão ocorreu antes da eclosão do escândalo do mensalão. Lula anunciou ainda a criação da Secretaria de Relações Institucionais, sob o comando de Aldo Rebelo (PCdoB), para tratar especialmente das negociações com o Poder Legislativo.

\footnotetext{
${ }^{9}$ Lula entrega pessoalmente ao Congresso propostas das reformas tributária e previdenciária. Disponível em:https://www12.senado.leg.br/noticias/materias/2003/04/30/lula-entrega-pessoalmente-ao-congressopropostas-das-reformas-tributaria-e-previdenciaria

${ }^{10}$ Previdência passa com votos da oposição e sem mudanças. Disponível em: https://www2.senado.leg.br/bdsf/bitstream/handle/id/498819/2003-11-27.pdf?sequence=1

${ }^{11}$ PT expulsa radicais do partido. Disponível em: http://www1.folha.uol.com.br/folha/brasil/ult96u56445.shtml

${ }^{12}$ Bancadas partidárias sofreram 50 mudanças em 2003. Disponível em: http://www2.camara.leg.br/agencia/noticias/44044.html

${ }^{13}$ Lula faz a primeira reforma ministerial. Disponível em: https://noticias.uol.com.br/inter/efe/2004/01/23/ult1808u3761.jhtm

${ }^{14}$ Presidente escolheu Lando por exclusão. Disponível em: https://www1.folha.uol.com.br/fsp/brasil/fc2401200405.htm
} 
Nas eleições municipais de 2004, a então prefeita de São Paulo, Marta Suplicy (PT) rejeitou acordo com o PMDB em sua tentativa de reeleição ${ }^{15}$; ela acabou derrotada por José Serra, ex-presidenciável do PSDB em 2002. O PT e o PMDB não fecharam alianças na maior parte das capitais e grandes cidades do país. A relação entre as duas siglas ainda era fonte de tensão, mesmo com a nomeação de dois peemedebistas para o ministério. Michel Temer, presidente do partido, e seu grupo político permaneceram distantes do Palácio do Planalto. Lula aproximou-se do presidente do Senado, José Sarney, e do líder do partido na Casa, Renan Calheiros. Além disso, tratou de abrir canal de diálogo com os peemedebistas da Câmara por meio da indicação do deputado Eunício Oliveira, líder da bancada, para o ministério. De qualquer forma, a negociação não ocorreu de forma institucional; ao contrário, a Convenção Nacional do PMDB, sob o comando de Temer, aprovou em dezembro de 2004 a entrega dos cargos ocupados por integrantes do partido no governo, sob risco de expulsão em caso de descumprimento da decisão ${ }^{16}$. A decisão foi criticada pela ala governista do partido ${ }^{17}$.

O PPS resolveu deixar o governo Lula no final de 2004, mas, Ciro Gomes, ministro da Integração Nacional e candidato a presidente em 2002, optou por deixar a sigla e permanecer à frente da pasta. Embora com uma bancada pouca significativa, foi o segundo partido a deixar a coalizão governista - o PDT fez o mesmo ao final de 2003.

\subsection{A ELEIÇÃO DE SEVERINO CAVALCANTI E O MENSALÃO}

Em fevereiro de 2005, Lula sofreu a sua maior derrota política. Na eleição para a presidência da Câmara, o candidato apoiado pelo governo, Luiz Eduardo Greenhalgh (PT), perdeu a disputa para Severino Cavalcanti (PP), apoiado por parlamentares do baixo clero, pela oposição e por setores da base aliada. O placar da derrota foi expressivo: 300 votos a 195. A eleição foi marcada pela divisão dentro do próprio PT: o partido referendou oficialmente a candidatura de Greenhalgh; contudo, o deputado Virgílio Guimarães (PT) apresentou-se como candidato avulso ${ }^{18}$.

\footnotetext{
${ }^{15}$ Marta rejeita dar vice ao PMDB e lança Rui Falcão. Disponível em: http://www1.folha.uol.com.br/fsp/brasil/fc1303200423.htm

${ }^{16}$ PMDB decide deixar base governista do governo Lula. Disponível em: https://www1.folha.uol.com.br/folha/brasil/ult96u66225.shtml

${ }^{17}$ Sarney diz que Temer é "faccioso" e estimula divisão do PMDB. Disponível em: https://www1.folha.uol.com.br/folha/brasil/ult96u66232.shtml

${ }^{18}$ Independente, Severino Cavalcanti é eleito presidente da Câmara. Disponível em: http://www1.folha.uol.com.br/folha/brasil/ult96u67210.shtml
} 
Após a eleição de Severino Cavalcanti (PP), o Congresso ficou meses sem realizar votações importantes; o governo obteve dificuldades até mesmo para obtenção de quórum nas sessões de votação ${ }^{19}$. Em maio de 2005, a revista Veja publicou denúncia sobre corrupção nos Correios, envolvendo o presidente do PTB, Roberto Jefferson. Em 6 de junho, em fatídica entrevista à Folha de São Paulo, Jefferson denunciou o mensalão - pagamento mensal a parlamentares aliados para votarem favoravelmente ao governo no Congresso - e responsabilizou o ministro-chefe da Casa Civil, José Dirceu, pela organização da prática ${ }^{20}$. O presidente do PTB acusou ainda o governo de incentivar a migração de parlamentares para o PP e o PL, o que teria sido a causa da expressiva movimentação partidária daqueles anos - o PTB, contudo, também havia se beneficiado das mudanças. Jefferson vinculou ainda a derrota do governo na eleição para a presidência da Câmara e as dificuldades na Casa a atrasos no pagamento do mensalão. O governo se viu envolvido em grave crise; em menos de 10 dias, Dirceu deixou o ministério. José Genoino, presidente nacional do PT, também acusado por Jefferson, afastou-se do cargo. Dirceu foi substituído pela petista Dilma Rousseff, então ministra das Minas e Energia; Tarso Genro deixou a pasta da Educação para assumir a presidência nacional do PT, sendo substituído pelo petista Fernando Haddad no ministério.

Em julho, como reação à mais grave crise de seu governo, Lula realizou nova reforma ministerial: aumentou o espaço do PMDB e integrou o PP ao seu gabinete. O presidente nomeou Silas Rondeau (PMDB), indicado de José Sarney, para a pasta de Minas e Energia, e Saraiva Felipe (PMDB), indicado pela bancada da Câmara, para o ministério da Saúde. A nomeação para a pasta da Saúde foi tentativa de Lula de contemplar a ala oposicionista do partido ${ }^{21}$. A direção nacional do PMDB, contudo, não chancelou o ingresso de peemedebistas; ao contrário, os membros do partido que aceitassem qualquer cargo no governo foram ameaçados de expulsão ${ }^{22}$. Lula também nomeou Márcio Fortes (PP), indicado por Severino Cavalcanti, para o ministério das Cidades ${ }^{23}$.

Todas as pastas eram ocupadas anteriormente por membros do PT e possuíam espaço importante para realização de investimentos. Lula sempre negou a existência do mensalão, mas

\footnotetext{
${ }^{19}$ Lula tenta reverter paralisia da Câmara. Disponível em: https://noticias.uol.com.br/ultnot/reuters/2005/05/13/ult27u48931.jhtm

${ }^{20}$ Jefferson denuncia mesada paga pelo tesoureiro do PT. Disponível em: https://www1.folha.uol.com.br/fsp/brasil/fc0606200502.htm

${ }^{21}$ Saiba quem é Saraiva Felipe, novo ministro da Saúde. Disponível em: https://www1.folha.uol.com.br/folha/brasil/ult96u70158.shtml

22 PMDB decide desligar membros do partido que ocupem cargos de confiança. Disponível em: https://www1.folha.uol.com.br/folha/brasil/ult96u70290.shtml

${ }^{23}$ Lula demite Olívio Dutra e vai nomear Márcio Fortes para Cidades. Disponível em: https://www1.folha.uol.com.br/folha/brasil/ult96u70642.shtml
} 
não descuidou de fortalecer sua articulação com o Poder Legislativo; ao contrário, como pode ser visto, o presidente agiu de forma rápida, aumentando imediatamente o espaço dos aliados no ministério. O compartilhamento do poder entre os partidos da coalizão aumentou drasticamente desde a posse até a metade de 2005, conforme pode ser visto na figura 4. Lula empenhou-se por dialogar com o Congresso e construir escudo legislativo - mesmo que no início de seu governo tenha dado preferência ao PT na composição ministerial. A relação sólida estabelecida ao longo dos anos com os partidos aliados e, sobretudo, a reação rápida do presidente quando da eclosão da crise do mensalão foram determinantes para a sobrevivência política do governo.

Figura 4. Investimentos dos Ministérios - Por Partido. Governo Lula I.

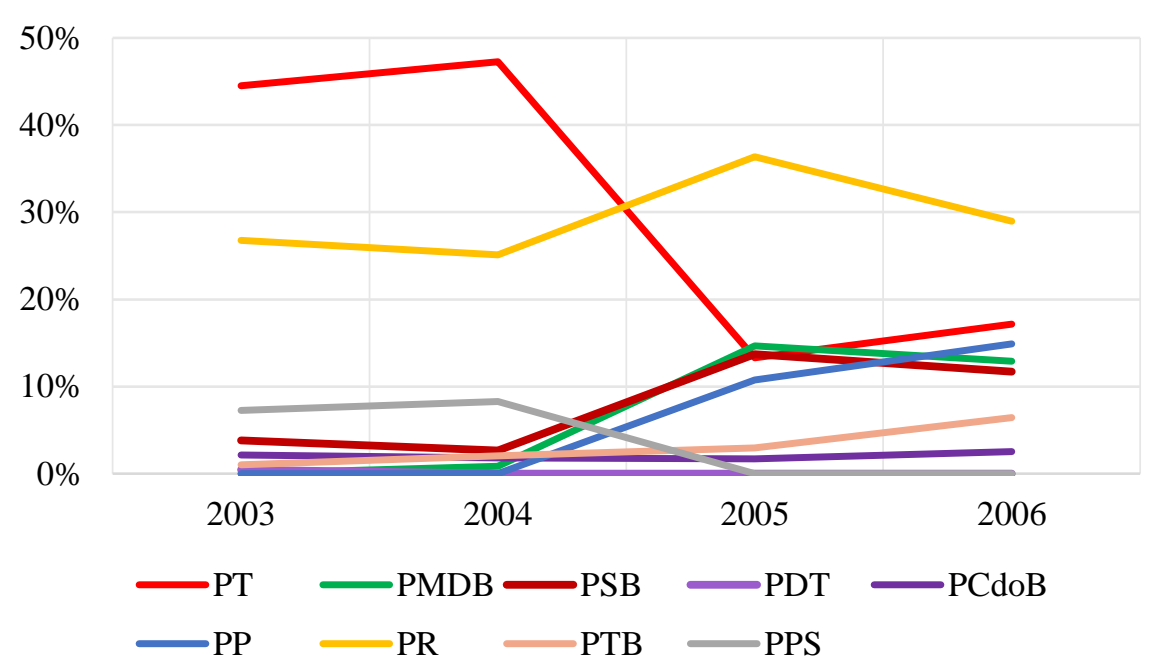

Fonte: Banco de dados do SIAFI. Valor empenhado, em porcentagem.

Em 11 de agosto, em depoimento à CPMI - Comissão Mista Parlamentar de Inquérito dos Correios, Duda Mendonça (que realizou a campanha publicitária de Lula na eleição de 2002) admitiu o uso de caixa 2 na campanha do petista ${ }^{24}$. Foi o momento mais tenso de todo o governo Lula. A abertura de impeachment contra o petista chegou a ser cogitada pela oposição $0^{25}$.

As condições políticas do Brasil em 2005, contudo, eram muito diferentes das condições do país em 2015 e 2016, quando Dilma Rousseff foi destituída pelo Congresso Nacional. Não obstante os escândalos de corrupção com ampla cobertura da mídia, a economia não se encontrava em recessão tampouco havia grandes manifestações nas ruas contra o presidente da

\footnotetext{
${ }^{24}$ Duda diz que recebeu $\mathbf{R} \$ \mathbf{1 0 , 5}$ milhões de caixa 2 em paraíso fiscal. Disponível em: https://www1.folha.uol.com.br/folha/brasil/ult96u71339.shtml

${ }^{25}$ Partidos de esquerda discutem impeachment ou antecipação de eleições. Disponível em: https://www1.folha.uol.com.br/folha/brasil/ult96u71383.shtml
} 
República. A popularidade presidencial caiu, mas em magnitude infinitamente menor - como pode ser observado na figura 5. O apoio a Lula manteve-se na faixa dos $30 \%$ mesmo no auge da crise.

Figura 5. Avaliação de Governo. Governo Lula I.

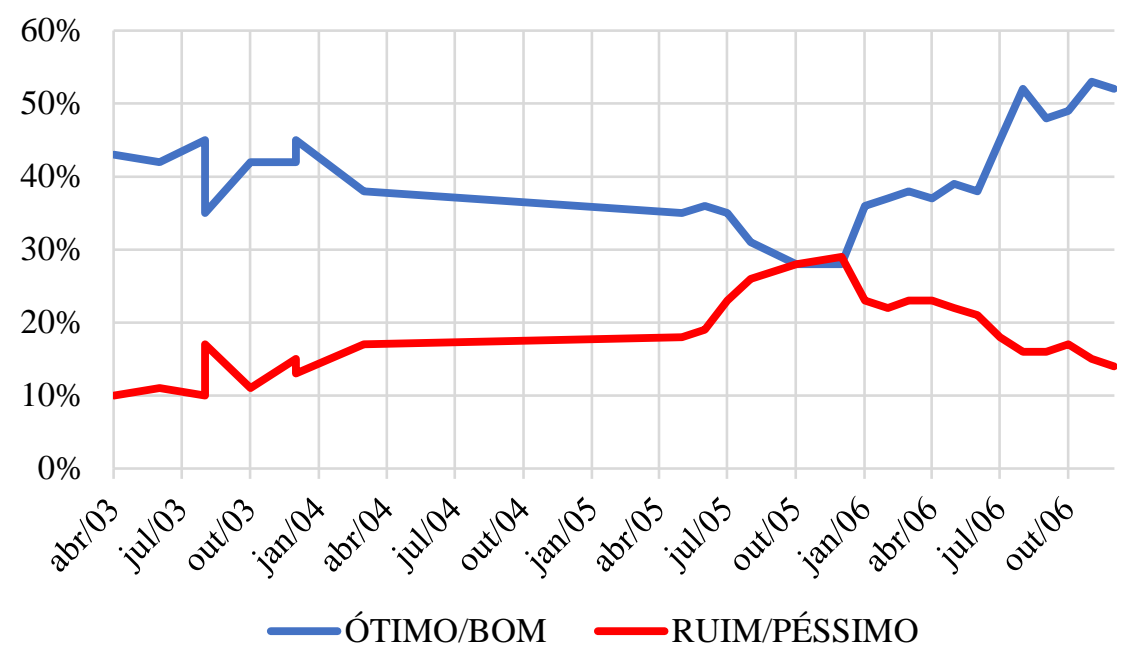

Fonte: Instituto Datafolha.

Além disso, de acordo com pesquisas realizadas à época, a maioria do eleitorado rejeitava o impeachment de $\mathrm{Lula}^{26}$. Ademais, embora o presidente tivesse perdido apoio popular, ele ainda possuía bom desempenho eleitoral em pesquisas presidenciais ${ }^{27}$. Tais elementos corroboram que o sucesso de eventual pedido de impeachment à época era bastante improvável. Em entrevista posterior, o senador Álvaro Dias, então no PSDB, lamentou a postura tímida da oposição, mas admitiu que o afastamento teria chances mínimas de $\operatorname{prosperar}^{28}$. De toda forma, não se pode subestimar a habilidade de Lula nas negociações com o Congresso Nacional, o que permitiu a construção do escudo legislativo de forma a blindar o presidente contra o risco de eventual pedido de afastamento.

Em setembro de 2005, o presidente da Câmara, Severino Cavalcanti (PP) se viu constrangido a renunciar ao cargo e ao mandato após a eclosão do escândalo do mensalinho, no qual o deputado foi acusado de cobrar propina para autorizar a exploração de restaurante na Casa. O governo soube aproveitar politicamente o evento para eleger um deputado aliado como

${ }^{26} 63 \%$ descartam, mas $29 \%$ defendem o impeachment. Disponível em: https://www1.folha.uol.com.br/fsp/brasil/fc1208200502.htm

${ }^{27}$ Apoio a Lula cai; Serra ganharia eleição. Disponível em: https://www1.folha.uol.com.br/fsp/brasil/fc1208200504.htm

28 'Não pedir impeachment em 2005 foi maior erro da oposição na Era Lula', afirma líder do PSDB. Disponível em: https://josiasdesouza.blogosfera.uol.com.br/2012/12/14/nao-pedir-impeachment-em-2005-foimaior-erro-da-oposicao-na-era-lula-afirma-lider-do-psdb/ 
novo presidente da Câmara. Com o apoio decisivo do presidente do Senado, Renan Calheiros (PMDB), de ministros indicados por partidos da coalizão e de líderes partidários envolvidos com o escândalo do mensalão, o governo elegeu Aldo Rebelo (PCdoB), ex-ministro da articulação política de Lula, como novo presidente da Casa ${ }^{29}$. A vitória do governo se deu por margem apertada - Rebelo obteve 258 votos e seu adversário, José Thomaz Nonô (PFL), 243 votos. O pefelista contou com o apoio de parcela expressiva do PMDB, inclusive do presidente do partido, Michel Temer - que chegou a lançar sua candidatura, mas desistiu diante das articulações do Palácio do Planalto e de seu correligionário Renan Calheiros em favor do deputado do PCdoB. O episódio deixou patente a divisão no $\mathrm{PMDB}^{30}$, mesmo após a reforma ministerial na qual o partido aumentou sua participação no governo. A eleição de Aldo Rebelo foi vitória importante de Lula e ajudou o petista a superar a crise política.

Ao final de 2005, os líderes do PT, do PL, do PP e do PMDB foram denunciados ao Conselho de Ética da Câmara dos Deputados. Alguns deles renunciaram. José Dirceu e Roberto Jefferson - além de Pedro Corrêa, presidente do PP - tiveram seus mandatos cassados pelo plenário. O PT teve sua imagem pública bastante abalada e Lula perdeu popularidade. Contudo, ao longo dos meses de 2006, conforme visto na figura 5 acerca da avaliação de governo, Lula melhorou seu desempenho nas pesquisas e lançou oficialmente sua candidatura à reeleição, mantendo José Alencar - agora no PRB - na posição de vice.

\subsection{LULA REELEITO E A ALIANÇA FORMAL COM O PMDB}

As eleições de 2006 foram realizadas sob as regras da verticalização, que determinou aos partidos nos estados seguirem as mesmas alianças estabelecidas no âmbito nacional. Por conta dessa regra, a maioria dos partidos optou por não participar da eleição presidencial.

O PSDB, após forte divisão interna, lançou a candidatura do governador de São Paulo, Geraldo Alckmin, em aliança com o PFL. O principal partido de oposição a Lula se dividiu entre as candidaturas de Alckmin, governador de São Paulo, e José Serra, prefeito da capital paulista. Em março, o PSDB decidiu lançar as candidaturas de Alckmin à presidência e Serra ao governo de São Paulo ${ }^{31}$.

\footnotetext{
${ }^{29}$ Aldo vence, dá gás a Lula e esperança aos "mensaleiros". Disponível em: http://www1.folha.uol.com.br/fsp/brasil/fc2909200502.htm

${ }^{30}$ Temer ataca Renan ao anunciar desistência. Disponível em: http://www1.folha.uol.com.br/fsp/brasil/fc2909200520.htm

${ }^{31}$ PSDB anuncia Geraldo Alckmin como candidato à Presidência. Disponível em: https://noticias.uol.com.br/ultnot/politica/ultimas/2006/03/14/ult3453u86.jhtm
} 
Do lado do PT, Lula somente anunciou sua candidatura à reeleição em junho. O exministro Ciro Gomes (PSB) teve seu nome cogitado para compor a chapa do PT, mas José Alencar (PRB) acabou permanecendo com a vaga de vice-presidente.

O PMDB chegou a realizar prévias entre Anthony Garotinho, ex-governador do Rio de Janeiro e ex-presidenciável - à época filiado à legenda -, e Germano Rigotto, governador do Rio Grande do Sul, em março de $2006^{32}$. Garotinho venceu as prévias, mas não se tornou o candidato do partido. Em Convenção Nacional em maio, o PMDB decidiu por não lançar candidatura própria, em razão da regra da verticalização e da pouca afinidade da sigla com o ex-governador fluminense ${ }^{33}$.

A eleição acabou se tornando um plebiscito acerca do governo Lula. O presidente, conforme pode ser visto anteriormente na figura 5, melhorou a avaliação de seu governo ao longo de 2006. Lula ficou a poucos votos de uma vitória em primeiro turno em uma eleição com poucos candidatos, sendo que ele obteve 48,6\% e Alckmin 41,6\% dos votos válidos. No segundo turno, o petista superou o patamar de $60 \%$.

Em novembro de 2006, após a reeleição, pela primeira vez, o PMDB aprovou oficialmente a participação do partido no governo Lula. A decisão contou com o respaldo da direção nacional e da ampla maioria do partido. Ao contrário do primeiro mandato, em que somente algumas alas apoiaram o petista, desta vez, a negociação com o PMDB ocorreu de forma institucional. O presidente da legenda, Michel Temer - que apoiou Alckmin na eleição - conduziu as negociações com Lula, que apresentou ao partido uma proposta de governo de coalizão. O PMDB, por aclamação, aceitou o convite de Lula ${ }^{34}$. Com o gesto, o presidente lançou as bases de uma aliança (PT-PMDB) que duraria por uma década e garantiria sucesso eleitoral e governabilidade aos governos petistas $^{35}$.

Em 2005, após a crise do mensalão, Lula tomou a decisão de aumentar significativamente a participação dos partidos aliados no ministério, sobretudo do PMDB e do PP, e reduzir o espaço do PT. A decisão de construir um governo de coalizão, compartilhando o ministério com os principais partidos governistas, foi aprofundada ao longo de seu segundo

\footnotetext{
32 Garotinho vence Rigotto, mas terá de esperar convenção do PMDB. Disponível em: https://noticias.uol.com.br/ultnot/2006/03/20/ult27u54539.jhtm

${ }^{33}$ Convenção do PMDB decide que partido não terá candidato a presidente. Disponível em: https://www.gazetadopovo.com.br/vida-publica/convencao-do-pmdb-decide-que-partido-nao-tera-candidato-apresidente-a0urn117e9sn5uugerc3dbqdq/

${ }^{34}$ PMDB aprova participação no governo de coalizão de Lula. Disponível em: http://g1.globo.com/Noticias/Politica/0,,AA1370004-5601,00.html

${ }^{35}$ Presidente quer negociar com PMDB unido. Disponível em: https://www1.folha.uol.com.br/fsp/brasil/fc0811200612.htm
} 
mandato ${ }^{36}$. O presidente chegou a admitir, após a reeleição, que cometeu erros na relação com o Congresso Nacional em seu primeiro quadriênio. ${ }^{37}$

Em 2007, na eleição para as presidências das Casas Legislativas, o PT firmou aliança com o PMDB para a realização de rodízio para a presidência da Câmara dos Deputados - os dois partidos elegeram as maiores bancadas, conforme pode ser visto na tabela 2 , abaixo. Pelo acordo construído, a presidência da Casa coube ao PT no biênio 2007-2008 e ao PMDB no biênio 2009-2010. No Senado, a presidência seguiu com o PMDB. Assim, o PT evitou a repetição do episódio Severino Cavalcanti. Em 2007, Arlindo Chinaglia (PT) elegeu-se presidente da Câmara e Renan Calheiros (PMDB) elegeu-se presidente do Senado. No biênio seguinte, seria a vez de Michel Temer (PMDB) e José Sarney (PMDB).

Tabela 2. Bancadas dos Partidos - Deputados Federais Eleitos.

\begin{tabular}{|c|c|c|c|}
\hline \multicolumn{2}{|c|}{2002} & \multicolumn{2}{|c|}{2006} \\
\hline Partido & Bancada & Partido & Bancada \\
\hline $\mathrm{PT}$ & 91 & PMDB & 89 \\
\hline PFL & 84 & PT & 83 \\
\hline PMDB & 75 & PSDB & 66 \\
\hline PSDB & 70 & PFL & 65 \\
\hline PPB & 49 & $\mathrm{PP}$ & 41 \\
\hline PTB & 26 & PSB & 27 \\
\hline PL & 26 & PDT & 24 \\
\hline PSB & 22 & PL & 23 \\
\hline PDT & 21 & PPS & 22 \\
\hline PPS & 15 & PTB & 22 \\
\hline PCdoB & 12 & PCdoB & 13 \\
\hline PRONA & 6 & PV & 13 \\
\hline PV & 5 & PSC & 9 \\
\hline Outros & 11 & Outros & 16 \\
\hline
\end{tabular}

Fonte: Câmara dos Deputados.

Além disso, o governo atuou para evitar a disputa interna na eleição para a presidência do PMDB. Enquanto setores ligados a Michel Temer - a antiga ala oposicionista - trabalhavam por sua recondução, a ala governista ligada a Renan Calheiros e José Sarney atuou para a eleição

\footnotetext{
${ }^{36}$ Verba sob controle do PMDB deve aumentar 55\%. Disponível em: https://www1.folha.uol.com.br/folha/bbc/ult272u61609.shtml

${ }^{37}$ Lula diz que errou na relação com Congresso. Disponível em: https://www1.folha.uol.com.br/fsp/brasil/fc0811200610.htm
} 
de Nelson Jobim, ex-ministro do STF, para o comando do partido. O Palácio do Planalto agiu de modo a pacificar o partido aliado. Ao final, Jobim desistiu da disputa e Temer foi reconduzido à presidência do PMDB. Depois de firmar aliança institucional com o partido, a intromissão do governo para favorecer a antiga ala governista seria muito mal recebida. Dessa forma, ao contrário, Lula acabou por aceitar a maioria de Temer no partido e a autonomia do PMDB para eleger seus próprios dirigentes ${ }^{38}$.

Após a convenção do PMDB, Lula anunciou reforma ministerial e sua equipe para o segundo mandato. O PMDB - que já comandava as pastas de Minas e Energia, Comunicações e Saúde - ganhou também os ministérios da Agricultura e da Integração Nacional ${ }^{39}$. De acordo com a negociação com o PMDB, as pastas das Minas e Energia e das Comunicações permaneceram com a ala do partido ligada ao Senado; as pastas da Agricultura e da Integração Nacional foram destinadas à ala da Câmara. O ex-líder Geddel Vieira Lima, ligado a Michel Temer e ferrenho opositor de Lula no primeiro mandato, foi nomeado para a Integração Nacional. Além disso, o ministério da Saúde foi negociado com o PMDB do Rio de Janeiro, diretório regional mais relevante do partido. Por fim, Nelson Jobim foi nomeado para a pasta da Defesa. Desta forma, o PMDB superou o PT no critério orçamento de investimento empenhado pelos ministros durante todo o segundo governo Lula, como mostra a figura 6.

Figura 6. Investimentos dos Ministérios - Por Partido. Governo Lula.

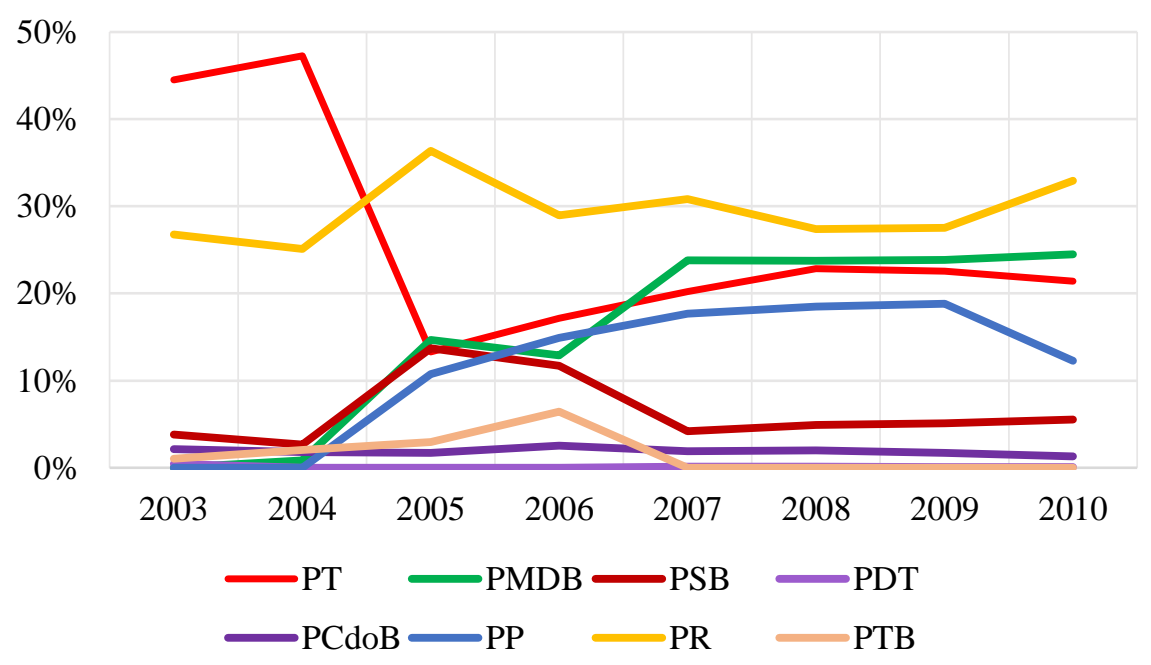

Fonte: Banco de dados do SIAFI. Valor empenhado, em porcentagem.

\footnotetext{
38 Temer é reeleito presidente do PMDB com 598 votos. Disponível em: http://www1.folha.uol.com.br/folha/brasil/ult96u90189.shtml 
Além do PMDB, Lula trouxe de volta ao seu governo o PDT, para a pasta do Trabalho. Os espaços dos demais partidos foram mantidos, inclusive o PP no Ministério das Cidades um dos maiores orçamentos da Esplanada e uma das pastas mais cobiçadas ${ }^{40}$. As empresas estatais também permaneceram com sua gestão compartilhada com os partidos aliados sobretudo entre PT, PMDB e PP. Já o PR não participou da gestão de estatais, mas, por outro lado, manteve durante todo o governo Lula o comando do ministério dos Transportes, uma das pastas com maior capacidade de investimento. Por essa razão, compreende-se o desempenho do partido na figura 6 , acima.

Em relação a Petrobras, é preciso rememorar brevemente as indicações partidárias para a composição da diretoria da companhia. Em sua delação premiada ${ }^{41}$, Paulo Roberto Costa, Diretor de Abastecimento entre 2004 e 2012, atribuiu sua nomeação ao PP. Já na Diretoria Internacional, Nestor Cerveró (2003-2008) e Jorge Zelada (2008-2012), teriam sido indicados pelo PMDB. Por fim, Renato Duque (2003-2012), na Diretoria de Serviços, devia sua indicação ao PT. Segundo Costa, embora essas indicações retomem ao primeiro mandato de Lula, o "petrolão" somente começou a funcionar - como um processo de cartelização - a partir do final de 2006. De acordo com essas informações, os ganhos obtidos com o esquema seriam distribuídos entre os diretores e os partidos aos quais representavam. Em 2005, houve substituição na presidência da estatal: saiu José Eduardo Dutra e entrou José Sérgio Gabrielli, ambos ligados ao $\mathrm{PT}^{42}$.

Embora o folclore político tenha atribuído a Severino Cavalcanti (PP) indicações políticas para a Petrobras - em 2005, ele expressou publicamente seu desejo de indicar o diretor de Produção e Exploração da Petrobras ${ }^{43}$, ocupado por indicado do PT -, isso jamais veio a ocorrer. As indicações para estatais já haviam sido realizadas desde o início do governo Lula. Com a descoberta do pré-sal em 2007 e a recuperação econômica, criou-se, segunda a delação de Paulo Roberto Costa, o ambiente propício para o petrolão entrar em operação.

\footnotetext{
${ }^{40}$ Presidente completa reforma ministerial. Disponível em: https://www.folhadelondrina.com.br/politica/presidente-completa-reforma-ministerial-597422.html

${ }^{41}$ Leia e ouça trechos do depoimento de Paulo Roberto Costa à Justiça. Disponível em: https://www1.folha.uol.com.br/poder/2014/10/1529925-leia-trechos-do-depoimentos-de-paulo-roberto-costa-ajustica.shtml

${ }^{42}$ Gabrielli será o novo presidente da Petrobras. Disponível em: https://economia.estadao.com.br/noticias/geral,gabrielli-sera-o-novo-presidente-da-petrobras,20050718p8411 43 " $O$ que o presidente (Lula) me ofereceu foi aquela diretoria que fura poço e acha petróleo. É essa que eu quero". Disponível em: https://acervo.oglobo.globo.com/frases/o-que-presidente-lula-me-ofereceu-foi-aqueladiretoria-que-fura-poco-acha-petroleo-essa-que-eu-quero-9152017
} 
Em relação ao setor elétrico, durante o segundo governo Lula, houve predomínio de indicações do PMDB para as principais companhias, como Eletrobras, Eletronorte e Furnas, por exemplo - embora o PT também tido participação relevante em determinados períodos.

É importante enfatizar que eventuais ganhos obtidos pelos partidos políticos por meio de corrupção não são a essência a ser considerada pelo trabalho. O que importa é a divisão de poder entre os partidos na execução de políticas públicas, de modo a permitir ganhos políticos aos executores. Por fim, em razão da gestão das empresas estatais ser geralmente compartilhada entre os partidos políticos - como no caso da Petrobras -, é inviável análise quantitativa acerca dos benefícios que cada legenda obteve por meio da realização de investimentos. De toda forma, encontram-se nos anexos informações detalhadas sobre o tema.

Conforme pode ser observado na figura 2 do capítulo 3, o governo Lula obteve taxas elevadas de apoio ao governo no Poder Legislativo entre os partidos da coalizão. Após a crise do mensalão, o apoio ao governo sofreu leve queda, mas a recuperação ocorreu de forma célere. Em seu segundo mandato, Lula obteve taxas de apoio superiores a 90\% entre os partidos que integravam a coalizão de governo. É possível relacionar o maior espaço concedido aos partidos aliados no ministério ao bom desempenho do governo no poder Legislativo. Ao longo do seu governo, sobretudo em seu segundo mandato, o presidente buscou ao máximo a construção de governo de coalizão, em que partidos aliados puderam participar do governo tanto quanto o partido do presidente, ao menos no que toca à implementação de políticas públicas e à realização de investimentos.

Ao mesmo tempo em que consolidou a sua aliança com os partidos da coalizão, Lula também se beneficiou do bom desempenho da economia em seu segundo mandato. Em 2007, o presidente lançou o PAC - Programa de Aceleração do Crescimento, com objetivo de promover a retomada do planejamento de grandes obras de infraestrutura no país. Além disso, o anúncio da descoberta do pré-sal pela Petrobras, como dito anteriormente, também foi importante marca para o governo. O cenário político e econômico brasileiro nesse momento permitiu a Lula aumentar a níveis bastante consideráveis a sua popularidade durante o segundo mandato, como pode ser visto na figura 7. 
Figura 7. Avaliação de Governo. Governo Lula.

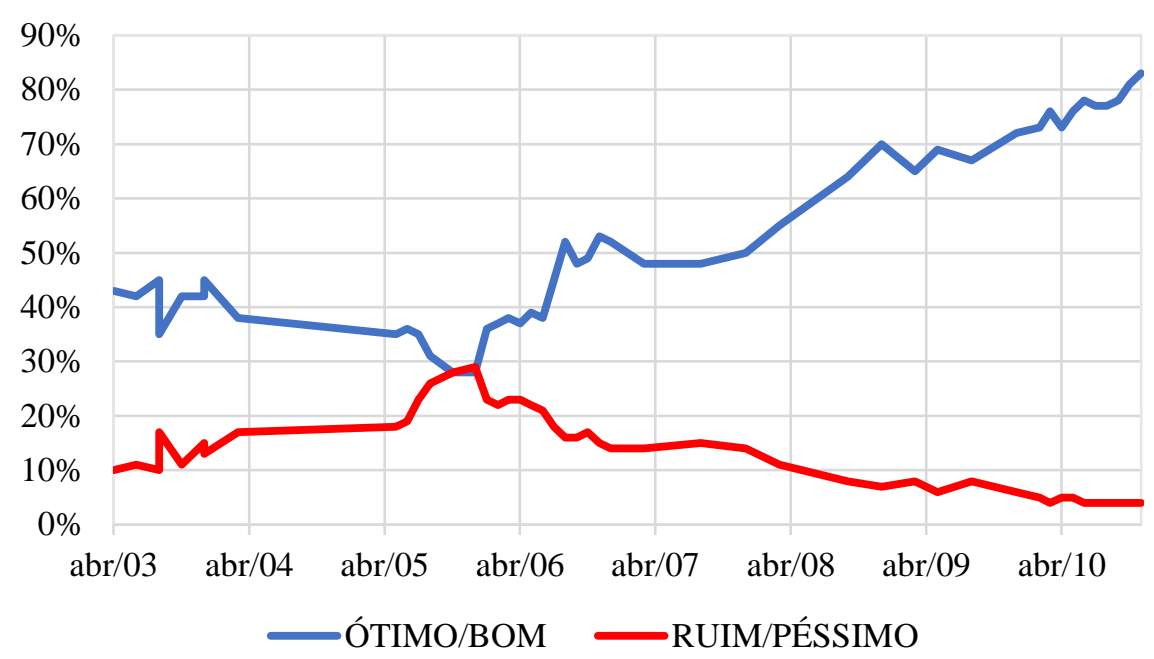

Fonte: Instituto Datafolha.

Ainda assim, o governo obteve percalços ao final de 2007. O presidente do Senado, Renan Calheiros, precisou renunciar ao cargo em razão do escândalo envolvendo o possível recebimento de recursos de empreiteiros para o pagamento de pensão para uma filha de relação extraconjugal com a jornalista Mônica Velloso ${ }^{44}$. Nesse sentido, o governo assistiu a certa desorganização na articulação política na Casa. O Senado rejeitou a medida provisória que criava a Secretaria de Ações de Longo Prazo (Sealopra), para qual havia sido nomeado Mangabeira Unger ${ }^{45}$. Ao final do ano, o governo não obteve votos suficientes para aprovar a renovação da CPMF (Comissão Provisória sobre Movimentações Financeiras) ${ }^{46}: 45$ senadores votaram a favor da proposta, mas eram necessários 48 votos por se tratar de emenda constitucional. Contudo, foram derrotas pontuais que não devem ser sobrevalorizadas.

Em 2008, a Petrobras deu início oficialmente à exploração do pré-sal. Em 2009, foi definido o novo marco regulatório do petróleo e o governo federal lançou o programa Minha Casa Minha Vida. A popularidade de Lula seguiu em trajetória de alta e a proposta de terceiro mandato para o petista chegou a ser discutida por aliados. No entanto, o presidente não deu prosseguimento a essas tratativas ${ }^{47}$ e o nome da ministra-chefe da Casa Civil, Dilma Rousseff

\footnotetext{
${ }^{44}$ Renan renuncia à presidência do Senado para evitar perder mandato. Disponível em: http://g1.globo.com/noticias/politica/0,,mul203841-5601,00-renan+renuncia+a+presidencia+do+senado.html ${ }^{45}$ Senado rejeita MP que criava secretaria para Mangabeira Unger. Disponível em: http://g1.globo.com/Noticias/Politica/0,,MUL110817-5601,00.html

${ }^{46}$ Senado derruba prorrogação da CPMF. Disponível em: http://g1.globo.com/noticias/economia negocios/0,,mul215356-9356,00-

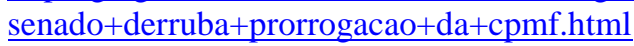

47 'Não tem terceiro mandato', diz Lula. Disponível em: http://politica.estadao.com.br/noticias/geral,nao-tem-terceiro-mandato-diz-lula,373820
} 
(PT), surgiu como a favorita de Lula para a sua sucessão. Mesmo sem nunca ter concorrido a cargo eletivo, a ministra acumulou capital político na gestão Lula e foi apresentada como a “mãe do PAC" e gestora competente. Em outubro de 2009, PT e PMDB fecharam acordo para apoiar a candidatura de Dilma Rousseff; os peemedebistas indicariam o candidato a vice ${ }^{48}$.

Desde o primeiro momento, o nome de Michel Temer, presidente nacional do PMDB, surgiu como o mais provável para ocupar o cargo. Lula tentou convencer o partido aliado a bancar a indicação do presidente do Banco Central, Henrique Meirelles, recém-filiado, para compor a chapa com Dilma Rousseff, mas não obteve sucesso ${ }^{49}$. Em abril, após negociação, Lula aceitou a indicação de Temer para a chapa e reconheceu que o peemedebista foi bemsucedido ao unificar o partido ${ }^{50}$. Além disso, à época, Temer ocupava a presidência da Câmara, o que lhe garantiu prestígio para postular a vice-presidência. Com a concordância de Lula e do PT, o PMDB formalizou o apoio a Dilma na convenção do partido em junho ${ }^{51}$. A aliança entre PT e PMDB se consolidaria ainda com o apoio petista a candidatos peemedebistas aos governos do Rio de Janeiro - Sérgio Cabral - e de Minas Gerais - Hélio Costa.

Em 2010, o PT obteve também os apoios formais do PSB (que retirou a pré-candidatura de Ciro Gomes ${ }^{52}$ ), do PR, do PDT, do PCdoB e do PRB - além de legendas menores como o PSC, o PTC e o PTN. O PP optou pela neutralidade, embora a direção nacional do partido tenha manifestado seu apoio a Dilma Rousseff ${ }^{53}$. A ampla coalizão de governo que deu sustentação ao segundo governo Lula decidiu apoiar, em sua maioria, o projeto eleitoral do governo. A coligação eleitoral garantiu à candidata amplo espaço na televisão, o que lhe permitiu tornar-se conhecida e derrotar o candidato tucano, o ex-governador paulista José Serra, no segundo turno. A eleição contou ainda com a participação da ex-ministra Marina Silva (PV) que, apesar não ter passado ao segundo turno, obteve votação significativa. Dilma Rousseff, amparada pela

\footnotetext{
${ }^{48}$ PT e PMDB fecham acordo por chapa de Dilma Rousseff em 2010. Disponível em: https://www.terra.com.br/noticias/brasil/politica/pt-e-pmdb-fecham-acordo-por-chapa-de-dilma-rousseff-em2010,98096f7d7fc4b310vgncld200000bbcceb0arcrd.html

${ }^{49}$ Lula defende Henrique Meirelles como vice de Dilma em 2010. Disponível em:

http://www.infomoney.com.br/mercados/noticia/1767283/lula-defende-henrique-meirelles-como-vice-dilma2010

${ }^{50}$ Lula se dá por vencido e Michel Temer será o vice de Dilma. Disponível em:

https://www.portalodia.com/noticias/politica/lula-se-da-por-vencido-e-michel-temer-sera-o-vice-de-dilma73875.html

${ }^{51}$ PMDB oficializa Michel Temer como vice na chapa de Dilma. Disponível em:

http://g1.globo.com/especiais/eleicoes-2010/noticia/2010/06/pmdb-oficializa-michel-temer-como-vice-na-chapade-dilma.html

${ }^{52}$ PSB oficializa retirada de candidatura de Ciro Gomes à Presidência. Disponível em: http://g1.globo.com/politica/noticia/2010/04/psb-oficializa-retirada-de-candidatura-de-ciro-gomespresidencia.html

${ }^{53}$ PP anuncia apoio informal a Dilma, mas não cede tempo de TV. Disponível em: http://g1.globo.com/politica/noticia/2010/07/pp-anuncia-apoio-informal-a-dilma-mas-nao-cede-tempo-de-tv$\underline{1 . h t m l}$
} 
elevada popularidade de Lula, elegeu-se presidente com $56 \%$ dos votos, garantindo ao PT o terceiro mandato presidencial subsequente.

A eleição de sua sucessora marcou ressurgimento surpreendente para o presidente que obteve tantas dificuldades em seu primeiro mandato, inclusive com a eclosão do escândalo do mensalão. Sem dúvidas, a economia cumpriu papel fundamental para a elevação da popularidade de Lula e para a eleição de Dilma. Não se pode, contudo, minorar a importância da construção de coalizão de governo amplamente majoritária, que garantiu ao governo êxito expressivo nas votações no Congresso Nacional. Os partidos foram contemplados no ministério, não houve concentração de recursos no partido do presidente e o PT dispôs-se a apoiar aliados em importantes eleições regionais em 2010. Mais do que isso, o presidente não se opôs a que os partidos membros da coalizão 'explorassem' os postos que passaram a ocupar em ministérios e empresas estatais. O caso mais evidente foi o de Geddel Vieira Lima, ministro da Integração Nacional no segundo governo Lula, que concentrou a destinação de recursos para municípios baianos e se lançou candidato ao governo da Bahia em 2010, contra o governador petista Jaques Wagner, que buscava a reeleição ${ }^{54}$.

O cenário mudou drasticamente a partir de 2011. Como se verá ao longo dos próximos dois capítulos, os conflitos entre a nova presidente e a coalizão de governo surgiram antes mesmo da posse, perduraram por todo o governo e culminaram na destituição de Dilma Rousseff.

\footnotetext{
${ }^{54}$ Geddel privilegia prefeitos do PMDB da Bahia. Disponível em: https://www1.folha.uol.com.br/fsp/brasil/fc2310200823.htm
} 


\section{A ELEIÇÃO DE DILMA ROUSSEFF}

Em 2010, logo após a sua eleição, Dilma Rousseff deu início à formação de seu ministério. Em uma forma de contemplar seu antecessor e a corrente majoritária do PT (Construindo um Novo Brasil), Antônio Palocci foi nomeado para a Casa Civil. O ex-ministro havia sido escolhido por Lula para o ministério da Fazenda em 2003, mas acabou afastado do cargo em 2005, após o escândalo sobre o seu possível envolvimento na violação do sigilo do caseiro Francenildo Santos Costa. Guido Mantega, titular da pasta da Fazenda desde meados de 2005, foi mantido no cargo por Dilma Rousseff.

Nas pastas da área social, o petista Fernando Haddad foi mantido no ministério da Educação. Em relação à pasta da Saúde, houve alteração importante. Saiu José Gomes Temporão, que havia sido chancelado pelo PMDB do Rio de Janeiro, e entrou Alexandre Padilha, do PT paulista e ex-ministro das Relações Institucionais de Lula.

A substituição na pasta da Saúde ocorreu dentro de contexto de redução do espaço do PMDB no gabinete ministerial. No segundo governo Lula, o partido comandava - além da Saúde - os ministérios da Agricultura, Integração Nacional, Minas e Energia, Comunicações e Defesa. Ao assumir, Dilma Rousseff alterou esse equilíbrio. O PMDB perdeu as pastas da Saúde, da Integração Nacional - as duas com maior espaço para a realização de investimentos, dentre as que estavam sob controle do partido - e das Comunicações. Além disso, Nelson Jobim foi demitido do ministério da Defesa pela nova presidente poucos meses depois da posse. $\mathrm{O}$ PMDB manteve o comando dos ministérios da Agricultura e das Minas e Energia e ganhou três pastas de menor relevância - Turismo, Previdência e Assuntos Estratégicos. Como pode ser observado, o PMDB começou o governo desprestigiado ${ }^{55}$.

Houve ruído sobretudo em relação ao ministério da Saúde. Na segunda gestão de Lula, o governador Sérgio Cabral apadrinhou a indicação do médico José Gomes Temporão para a pasta; já o comando da Funasa (Fundação Nacional da Saúde) ficou sob o comando de Danilo Forte, indicado pelo PMDB da Câmara. Dilma Rousseff, por sua vez, não aceitou uma nova indicação de Cabral para a pasta durante a formação de seu gabinete e entregou o ministério ao PT. O governador do Rio de Janeiro chegou a anunciar seu secretário de Saúde como novo ministro, mas foi desautorizado pela presidente da República ${ }^{56}$. Posteriormente, o partido da

\footnotetext{
${ }^{55}$ PMDB insiste em quinto ministério no governo Dilma. Disponível em: http://www1.folha.uol.com.br/fsp/poder/po0612201009.htm

${ }^{56}$ Dilma desmente Cabral e diz que ainda não escolheu ministro da Saúde. Disponível em: https://politica.estadao.com.br/noticias/geral,dilma-desmente-cabral-e-diz-que-ainda-nao-escolheu-ministro-da$\underline{\text { saude, } 648079}$
} 
presidente passou a comandar os principais órgãos da pasta $^{57}$, inclusive a Funasa ${ }^{58}$, o que naturalmente não agradou ao PMDB.

O ministério da Integração Nacional, que estava sob o comando de Geddel Vieira Lima no segundo governo Lula, foi entregue ao PSB, para um afilhado político do governador de Pernambuco, Eduardo Campos. Os demais partidos aliados mantiveram espaço semelhante ao obtido durante o segundo governo Lula.

O partido da presidente, contudo, aumentou significativamente seu espaço. A figura 8 mostra a participação dos partidos da coalizão no ministério de acordo com o orçamento de investimento. A redução do espaço do PMDB e a elevação na participação do PT são evidentes. Nesse sentido, a declaração do então líder do PMDB, Henrique Eduardo Alves, é ilustrativa: “ao contrário dos ministérios do PT, como Saúde e Educação, e do PSB, como Integração Nacional, nossos ministérios não dispõem de verbas para que possamos anunciar obras nos municípios. Ficamos na dependência do PT"59.

Figura 8. Investimentos dos Ministérios - Por Partido. Governos Lula II e Dilma I.

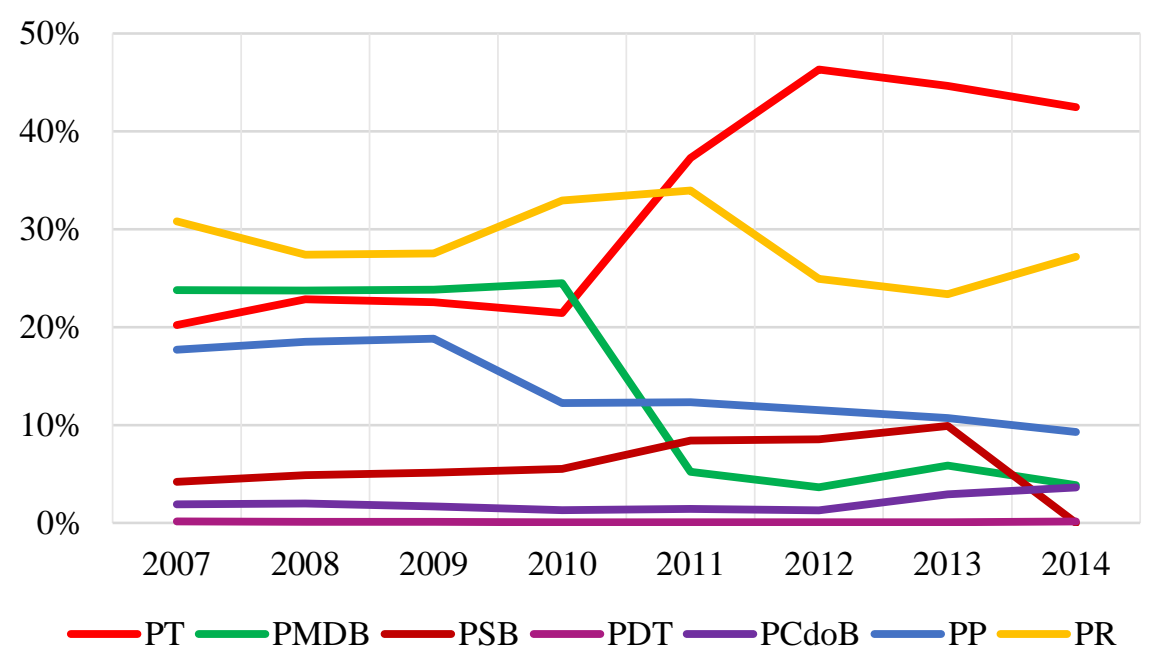

Fonte: Banco de dados do SIAFI. Valor empenhado, em porcentagem.

\footnotetext{
${ }^{57}$ Padilha troca ligado ao PMDB por petista em secretaria. Disponível em: https://ultimosegundo.ig.com.br/politica/padilha-troca-ligado-ao-pmdb-por-petista-emsecretaria/n1237937699550.html

${ }^{58}$ Mineiro ligado ao PT é nomeado presidente da Funasa. Disponível em: https://www.em.com.br/app/noticia/politica/2011/04/28/interna_politica,224272/mineiro-ligado-ao-pt-enomeado-presidente-da-funasa.shtml

${ }^{59}$ Em crise com o Planalto, base cobra novo modelo de relação com Dilma. Disponível em: https://politica.estadao.com.br/noticias/geral,em-crise-com-o-planalto-base-cobra-novo-modelo-de-relacao-comdilma, 846709
} 
A formação do ministério foi o primeiro conflito entre a presidente e a coalizão; contudo, como ver-se-á ao longo do capítulo, a escalada de conflitos teria continuidade ao longo dos anos e causaria grande estresse na relação entre o Executivo e o Legislativo, especialmente durante o segundo governo de Dilma Rousseff.

\subsection{DA FAXINA ÀS MANIFESTAÇÕES DE JUNHO DE 2013}

A figura 8, mostrada anteriormente, evidencia o compartilhamento de poder entre os partidos da coalizão durante o governo de Dilma Rousseff. Enquanto o partido da presidente aumentou sua participação, os aliados, sobretudo o PMDB, perderam espaço. Esse novo padrão vigorou durante todo o primeiro mandato da presidente.

O ministro-chefe da Casa Civil, Antônio Palocci, que possuía boa relação com o Congresso Nacional foi rapidamente substituído em meio a denúncias sobre tráfico de influência. A senadora petista Gleisi Hoffmann assumiu o ministério. Dilma Rousseff efetivou em seguida a troca do ministro das Relações Institucionais, Luiz Sérgio, pela ex-senadora Ideli Salvatti - ambos petistas. As substituições ocorreram em junho de 2011.

As trocas ministeriais, no entanto, não pararam por aí. O ano de 2011 foi marcado por substituições em série de ministros acusados de envolvimento com corrupção. O episódio ficou conhecido como "faxina ética" na Esplanada dos Ministérios ${ }^{60}$. O primeiro alvo foi o então ministro dos Transportes, Alfredo Nascimento, que, à época, exercia a presidência nacional do PR. Ele deixou o ministério em julho, em meio a acusações de superfaturamento em obras públicas. Em agosto, a bancada do PR decidiu adotar posição de independência em relação ao governo $^{61}$. O partido integrou a coalizão governista desde 2003 e Nascimento estava no cargo desde 2004. Como será observado posteriormente, a decisão de afastar o ministro teve repercussões importantes no comportamento do partido no Congresso. Se não bastasse a redução de espaço do PMDB, Dilma Rousseff decidiu afastar o presidente de um dos partidos da coalizão mais fiéis ao governo.

O segundo ministro a ser afastado - em agosto de 2011 - foi Wagner Rossi, da Agricultura, afilhado político do vice-presidente Michel Temer. Ele deixou o cargo em meio a

\footnotetext{
${ }^{60}$ Retrospectiva 2011: Faxina ministerial abre espaço para reforma na Esplanada depois da saída de 7 ministros. Disponível em: http://politica.estadao.com.br/noticias/geral,retrospectiva-2011-faxina-ministerialabre-espaco-para-reforma-na-esplanada, 812647

${ }^{61}$ Alfredo Nascimento rompe com o governo Dilma e declara independência do PR. Disponível em: https://oglobo.globo.com/politica/alfredo-nascimento-rompe-com-governo-dilma-declara-independencia-do-pr$\underline{2690023}$
} 
denúncias de irregularidades na Conab (Companhia Nacional de Abastecimento). O seu substituto foi o deputado federal Mendes Ribeiro (PMDB-RS) que, não obstante a proximidade com a presidente ${ }^{62}$, enfrentou dificuldades com o próprio partido durante a sua gestão na pasta. Além de ter enfrentado problemas de saúde, o novo ministro foi desautorizado por Dilma Rousseff durante as negociações do Código Florestal ${ }^{63}$, o que levou o PMDB a defender a sua substituição, que veio a ocorrer em meados de 2013.

Outro peemedebista a deixar o ministério foi Pedro Novais, do Turismo - em setembro. Ele seria substituído por Gastão Vieira. Nesse caso, contudo, ambos eram pertencentes ao PMDB do Maranhão e próximos ao presidente do Senado, José Sarney, razão pela qual a substituição não teve maiores implicações ${ }^{64}$.

Em outubro, seria a vez de Orlando Silva, do PCdoB, entregar sua carta de demissão em meio a irregularidades envolvendo convênio com ONGs. Ele ocupava o cargo desde 2007 e foi substituído por Aldo Rebelo, também do PCdoB.

A demissão de Carlos Lupi do ministério do Trabalho em dezembro teve maior repercussão. O então ministro exercia a presidência nacional do PDT e sua demissão não foi bem-recebida por integrantes do partido. Ele estava à frente do ministério desde 2007 e foi substituído por Brizola Neto, seu adversário interno, que não obteve respaldo partidário ${ }^{65}$.

A "faxina" na Esplanada dos Ministérios seria concluída em fevereiro de 2012, com a demissão de Mário Negromonte, do PP, do ministério das Cidades. Ele foi substituído pelo líder do partido na Câmara, Aguinaldo Ribeiro.

Conforme pode ser observado, algumas substituições ministeriais obtiveram apoio dos respectivos partidos, outras não. Os casos de Alfredo Nascimento e Carlos Lupi, por se tratarem de presidentes de legendas integrantes da coalizão, e de Wagner Rossi, por se tratar de indicação do vice-presidente da República, tiveram implicações no comportamento dos partidos no Congresso. Em alguns casos, as reações tardaram a aparecer; em outros, como no caso do PR, a reação à faxina foi imediata - como se verá adiante, o apoio do PR ao governo na Câmara

\footnotetext{
${ }^{62}$ Próximo de Dilma, Mendes Ribeiro, novo ministro da Agricultura, encarou PMDB gaúcho por ela. Disponível em: https://oglobo.globo.com/politica/proximo-de-dilma-mendes-ribeiro-novo-ministro-daagricultura-encarou-pmdb-gaucho-por-ela-2688714

${ }^{63}$ Dilma proíbe ministro da Agricultura de falar sobre Código Florestal. Disponível em: https://politica.estadao.com.br/noticias/geral,dilma-proibe-ministro-da-agricultura-de-falar-sobre-codigoflorestal, 884251

${ }^{64}$ Peemedebista do Maranhão ligado a Sarney é o novo ministro. Disponível em: https://www.gazetadopovo.com.br/vida-publica/peemedebista-do-maranhao-ligado-a-sarney-e-o-novo-ministroc96swezqpzk7wvf3pu9unsdou/

${ }^{65}$ Deputados do PDT criticam escolha de Brizola Neto. Disponível em: https://oglobo.globo.com/brasil/deputados-do-pdt-criticam-escolha-de-brizola-neto-4777024
} 
caiu logo após a demissão do ministro. De toda forma, Dilma Rousseff, em vez de trabalhar pela construção de escudo legislativo, acabou por dinamitar pontes com os partidos da coalizão.

Apesar de integrantes do PT terem sido poupados das demissões - exceção feita a Antônio Palocci -, o partido não escondeu o incômodo com a "faxina" promovida por Dilma Rousseff. Em Congresso do partido realizado em 2011, o PT criticou as demissões de ministros e defendeu a reforma política como caminho para o combate à corrupção. O partido atribuiu à mídia e à oposição as manobras para criminalizar a política e enfraquecer a base de sustentação do governo ${ }^{66}$.

Os demais partidos da coalizão foram, em maior ou menor grau, atingidos pela "faxina" ministerial ${ }^{67}$. Os petistas, por sua vez, temeram que as ações de Dilma Rousseff acabassem por atribuir ao governo Lula a pecha de corrupto, já que todos os ministros afastados foram herdados da administração anterior. É possível identificar nesse episódio um precedente do que viria a ser comportamento da presidente durante a Operação Lava-Jato. No futuro, Dilma Rousseff viria a defender, mais de uma vez, as investigações da Lava-Jato ${ }^{68}$ e teria atuado, segundo delações premiadas, para responsabilizar o governo de seu antecessor e o Congresso pelas irregularidades cometidas ${ }^{69}$.

Nesse contexto, outra alteração importante promovida por Dilma Rousseff foi em relação às diretorias das empresas estatais. Na Petrobras, José Sérgio Gabrielli deixou a presidência da companhia no começo de 2012, sendo substituído por Graça Foster, bastante próxima à presidente da República. Na sequência, foram anunciadas as substituições dos diretores Paulo Roberto Costa (Abastecimento), Jorge Zelada (Internacional) e Renato Duque (Serviços). As demissões desagradaram aos partidos aliados, sobretudo PP, PMDB e PT, responsáveis pelas indicações ${ }^{70}$. À época, as alterações não mereceram tanta atenção; mas, como se verá ao longo do próximo capítulo, estão diretamente relacionadas ao processo que desencadeou o escândalo do petrolão. Também foram feitas alterações nas indicações para o

\footnotetext{
${ }^{66}$ Em documento, PT recusa 'faxina' de Dilma e pede reforma contra corrupção. Disponível em: http://politica.estadao.com.br/noticias/geral,em-documento-pt-recusa-faxina-de-dilma-e-pede-reforma-contracorrupcao, 767312

67 "Faxina de Dilma" contra a corrupção poupa PT e varre siglas aliadas. Disponível em: https://noticias.r7.com/brasil/noticias/-faxina-de-dilma-contra-a-corrupcao-poupa-pt-e-varre-siglas-aliadas20120216.html

${ }^{68}$ Dilma diz que investigações da Lava Jato podem mudar país para sempre. Disponível em: http://g1.globo.com/politica/operacao-lava-jato/noticia/2014/11/dilma-defende-petrobras-e-diz-que-o-que-deveser-condenado-sao-pessoas.html

${ }^{69}$ Dilma 'deu corda' para Lava Jato 'sufocar' Lula, diz Palocci. Disponível em: https://www.terra.com.br/noticias/brasil/politica/dilma-deu-corda-para-lava-jato-sufocar-lula-dizpalocci,66f760ea6f3cedcea1b2823120b37dc2ve4j3nrq.html

${ }^{70}$ Partidos se irritam com mudanças feitas por Graça na Petrobras. Disponível em: https://oglobo.globo.com/economia/partidos-se-irritam-com-mudancas-feitas-por-graca-na-petrobras-4749680
} 
setor elétrico. O PMDB da Câmara perdeu o comando de Furnas já no início de 2011, o que desagradou a Henrique Eduardo Alves e a Eduardo Cunha ${ }^{71}$.

A presidente da República ganhou politicamente com a "faxina". Conforme pode ser visto na figura 9, a popularidade de Dilma Rousseff subiu consideravelmente entre o final de 2011 e o começo de 2012. Contudo, se houve ganhos em relação à opinião pública, a relação com o Poder Legislativo e o sistema político sofreram estremecimento.

Figura 9. Avaliação de Governo. Governo Dilma 2011-12.

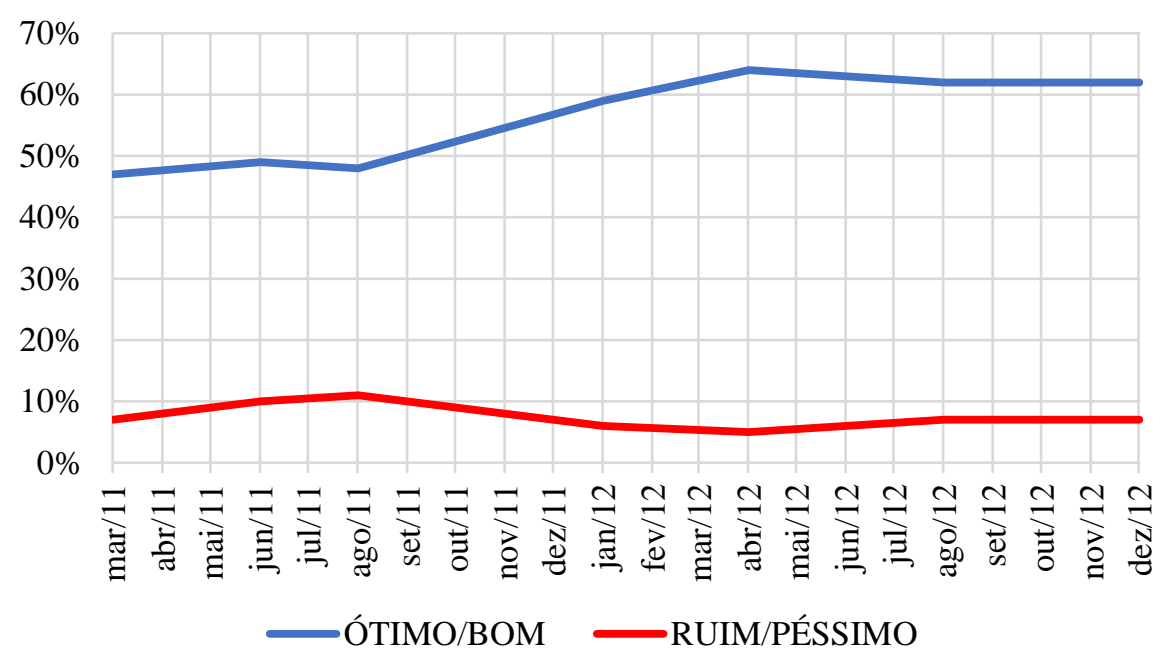

Fonte: Instituto Datafolha.

Além da redução do espaço dos partidos aliados no ministério e da demissão de ministros e diretores de empresas estatais supostamente envolvidos em escândalos de corrupção, outro fator viria a desgastar a relação entre a presidente da República e a coalizão de governo. Em 2011, foi fundado o PSD, organizado pelo prefeito de São Paulo Gilberto Kassab com objetivo de receber parlamentares integrantes da oposição dispostos a uma aproximação com o governo e ainda parlamentares aliados desconfortáveis com seus próprios $\operatorname{partidos}^{72}$. No início, 32 deputados anunciaram filiação ao PSD, oriundos de diversas legendas, sobretudo do DEM, partido ao qual Kassab era filiado à época - como pode ser observado na tabela 3 .

\footnotetext{
${ }^{71}$ Dilma rejeita indicações de Cunha e irrita PMDB do Rio. Disponível em: https://oglobo.globo.com/politica/dilma-rejeita-indicacoes-de-cunha-irrita-pmdb-do-rio-2828295

72 Criação do PSD provoca baixa na oposição, e DEM é o partido que mais perde. Disponível em: https://oglobo.globo.com/politica/criacao-do-psd-provoca-baixa-na-oposicao-dem-o-partido-que-mais-perde$\underline{2796958}$
} 
Tabela 3. Deputados que migraram para o PSD. 2011.

\begin{tabular}{|c|c|}
\hline DEM & 11 \\
\hline PP & 6 \\
\hline PPS & 3 \\
\hline PMN & 3 \\
\hline PSC & 2 \\
\hline PMDB & 1 \\
\hline PDT & 1 \\
\hline PCdoB & 1 \\
\hline PRB & 1 \\
\hline PV & 1 \\
\hline PRP & 1 \\
\hline PRTB & 32 \\
\hline Total & Fonte: Câmara dos Deputados.
\end{tabular}

O governo federal emprestou seu apoio à criação do PSD como meio de aumentar a sua base de sustentação no Congresso ${ }^{73}$ e ficar menos dependente do apoio do PMDB e demais partidos governistas. Contudo, a criação da legenda não foi bem-recebida pelos partidos da coalizão, que enxergaram na ação do Palácio do Planalto uma tentativa de enfraquecê-los. A reação viria nos anos seguintes, como se verá no próximo capítulo.

O ano de 2012 teve início em meio a dificuldades do governo no Congresso Nacional. Em fevereiro, Dilma Rousseff nomeou o senador Marcelo Crivella, do PRB, para o ministério da Pesca, em substituição a Luiz Sérgio, do PT. A nomeação foi um aceno do governo à bancada evangélica e também ao PRB que, apesar de possuir poucos integrantes no Congresso, era aliado do PT desde a sua criação em 2005. A relação com demais partidos da coalizão de governo, contudo, apresentava problemas.

O PDT ainda demonstrava bastante contrariedade com a demissão de Carlos Lupi do ministério do Trabalho. A bancada do PR havia se declarado independente após a demissão de Alfredo Nascimento da pasta dos Transportes. O PTB tentou, sem sucesso, retomar uma vaga no ministério ${ }^{74}$. O descontentamento também era grande no PMDB, que havia perdido espaço na equipe ministerial desde a posse da presidente. Os peemedebistas criticaram em manifesto público a postura hegemônica do PT. Dilma Rousseff chegou a viajar a São Paulo para encontrar-se com Lula e discutir a situação política do governo ${ }^{75}$. A crise com a coalizão

\footnotetext{
${ }^{73}$ Kassab funda PSD com promessa de apoio a Dilma. Disponível em: https://www1.folha.uol.com.br/fsp/poder/po1404201105.htm

${ }^{74}$ PTB e PSC formam bloco de olho no Ministério do Trabalho. Disponível em:

https://www.valor.com.br/politica/2581442/ptb-e-psc-formam-bloco-de-olho-no-ministerio-do-trabalho
} 
ocorreu no contexto de preparação para as eleições municipais de 2012 e os aliados queixavamse da possível interferência do Palácio do Planalto em favor do PT. Embora seja natural haver disputas dentro de uma coalizão de governo - nunca é demais lembrar as conclusões de Martin e Vanberg (2011) de que partidos políticos governam juntos, mas disputam eleições separadamente -, a insatisfação nesse caso atingiu praticamente toda a base de sustentação da presidente. $^{76}$.

Em uma manifestação dessa insatisfação, o plenário do Senado Federal rejeitou a recondução de Bernardo Figueiredo, bastante próximo a Dilma Rousseff, para a diretoria-geral da ANTT (Agência Nacional de Transportes Terrestres), com o placar de 36 votos contrários e 31 favoráveis ${ }^{77}$. Após o resultado, o então líder do governo na Casa, senador Romero Jucá (PMDB-RR), reconheceu o descontentamento generalizado da base aliada, que teria aproveitado a votação para enviar recado ao governo. A rejeição de indicações presidenciais pelo Senado não é algo trivial, tendo ocorrido raras vezes desde a redemocratização.

Em março de 2012, Dilma Rousseff anunciou a substituição dos líderes do governo no Poder Legislativo. Na Câmara, Cândido Vaccarezza (PT-SP) deu lugar a Arlindo Chinaglia (PT-SP). No Senado, saiu Romero Jucá (PMDB-RR) e entrou Eduardo Braga (PMDB-AM). Com as trocas, o governo optou por nomear parlamentares mais leais ao governo, mas que não necessariamente possuíam maior trânsito entre seus pares. Vacarreza, apesar de ser filiado ao PT, dispunha de bom trânsito com partidos aliados, incluindo o $\mathrm{PMDB}^{78}$. Já Romero Jucá, além da experiência de ter sido líder de três governos distintos (FHC, Lula e Dilma), sempre teve atuação destacada em comissões de elaboração orçamentária. Ao optar pela substituição desses nomes por parlamentares mais fiéis ao governo, Dilma Rousseff parece não ter conseguido compreender a necessidade de mudar a condução da articulação política dentro do Palácio do Planalto.

Em abril, a presidente sofreria nova derrota, durante a votação final do novo Código Florestal na Câmara dos Deputados. O placar foi de 274 votos favoráveis ao relatório do deputado Paulo Piau (PMDB-MG) e 184 votos contrários conforme orientação da liderança do

\footnotetext{
${ }^{75}$ Com PMDB à frente, base aliada se rebela, e Dilma busca socorro de Lula. Disponível em: http://politica.estadao.com.br/noticias/eleicoes,com-pmdb-a-frente-base-aliada-se-rebela-e-dilma-busca-socorrode-lula-imp-,842970

${ }^{76}$ Em crise com o Planalto, base aliada exige mais diálogo e menos poder ao PT. Disponível em: https://politica.estadao.com.br/noticias/eleicoes,em-crise-com-o-planalto-base-aliada-exige-mais-dialogo-emenos-poder-ao-pt-imp-, 846898

${ }_{77}$ Senado rejeita recondução ao cargo do presidente da ANTT. Disponível em: http://g1.globo.com/politica/noticia/2012/03/senado-rejeita-reconducao-de-bernardo-figueiredo-antt.html

${ }_{78}$ Vaccarezza era próximo ao PMDB e pertencia a uma ala menos ideológica do PT. Disponível em: https://politica.estadao.com.br/noticias/geral,ex-lider-do-governo-dilma-e-lula-vaccarezza-era-proximo-aopmdb-e, 70001942014
} 
governo. No ano anterior, o Executivo já havia sido derrotado na votação de emenda com o mesmo teor e com placar semelhante - 273 favoráveis e 182 contrários. O governo à época também orientou o voto contrário e foi derrotado pela base aliada, liderada pelo PMDB. O texto foi articulado pela frente parlamentar da agropecuária ${ }^{79}$.

Nas eleições municipais de 2012, o PT obteve vitória importante com a eleição de Fernando Haddad em São Paulo. Além disso, o partido expandiu o número de prefeituras conquistadas e se consolidou como a terceira força nos municípios. O PSB também obteve crescimento, enquanto os demais partidos da coalizão perderam espaço. Já o PMDB permaneceu como o partido com o maior número de prefeitos no Brasil, seguido pelo PSDB. O partido ainda reelegeu Eduardo Paes à frente da prefeitura do Rio de Janeiro - com o apoio do PT. Os peemedebistas retribuíram com o apoio ao petista Patrus Ananias em Belo Horizonte, que acabou derrotado na eleição. Nas eleições estaduais de 2010, o PT havia apoiado candidatos do PMDB no Rio de Janeiro e em Minas Gerais. No segundo turno da eleição paulista, o PMDB apoiou o PT contra o PSDB mediante negociação do vice-presidente Michel Temer ${ }^{80}$. A vitória em São Paulo fortaleceu o partido da presidente, embora não tenha havido o cenário de hegemonia do PT, como temido por partidos aliados anteriormente à realização das eleições municipais.

O segundo semestre de 2012 foi marcado ainda pela discussão em torno da Medida Provisória $n^{\circ} 579$, que reduziu a tarifa de energia elétrica, a partir da renovação antecipada de concessões de geradoras. O episódio marcou mais um embate entre Dilma Rousseff e o deputado Eduardo Cunha (PMDB-RJ), que foi escolhido relator revisor da matéria. Por fim, o PMDB fechou questão sobre o tema e a resistência de Cunha foi superada. O partido escolheu o senador Renan Calheiros (PMDB-AL) como relator principal da matéria e - em virtude de comandar o ministério de Minas e Energia - atuou para obter os ganhos políticos da redução da conta de luz dos brasileiros, medida de forte apelo popular ${ }^{81}$. A aprovação final do texto ocorreu em dezembro, após tramitação célere no Congresso.

\footnotetext{
${ }^{79}$ Aprovada reforma do Código Florestal; ruralistas impõem derrota ao governo. Disponível em: http://www.estadao.com.br/noticias/geral,aprovada-reforma-do-codigo-florestal-ruralistas-impoem-derrota-aogoverno-imp-, 865402

${ }^{80}$ PMDB oficializa apoio ao petista Fernando Haddad. Disponível em: https://www.em.com.br/app/noticia/politica/2012/10/11/interna_politica,323015/pmdb-oficializa-apoio-aopetista-fernando-haddad.shtml

${ }^{81}$ PMDB deve votar a favor de redução de tarifa de energia. Disponível em: https://www.em.com.br/app/noticia/politica/2012/12/10/interna_politica,335951/pmdb-deve-votar-a-favor-dereducao-de-tarifa-de-energia.shtml
} 
No começo de 2013, Eduardo Cunha foi escolhido líder do PMDB na Câmara - que possuía, à época, 80 deputados ${ }^{82}$. Por sua vez, o ex-líder da bancada Henrique Eduardo Alves (PMDB) foi eleito presidente da Câmara dos Deputados, sucedendo a Marco Maia (PT). O PT cumpriu o acordo com os peemedebistas e apoiou o candidato do partido à presidência da Casa. No Senado, Renan Calheiros sucedeu a José Sarney. No biênio 2013-2014, o PMDB acumulou, portanto, a vice-presidência da República com as presidências da Câmara e do Senado. Assim, mesmo com espaço reduzido no ministério, o partido organizou-se para ocupar as posições de maior relevância no Poder Legislativo.

Em março de 2013, o governo sofreria mais uma derrota na apreciação do veto de Dilma Rousseff à divisão dos royalties do petróleo. A base aliada derrubou o veto da presidente com ampla vantagem: 354 deputados e 54 senadores, restabelecendo a divisão dos royalties entre todos os Estados e Municípios do país ${ }^{83}$.

Em reforma ministerial realizada em seguida - em março de 2013 -, Dilma Rousseff atuou para contemplar os partidos aliados e reorganizar sua base de sustentação após as sucessivas derrotas ${ }^{84}$. Na pasta da Agricultura, Mendes Ribeiro - desgastado desde as negociações do Código Florestal - foi substituído pelo deputado Antônio Andrade, presidente do PMDB-MG. Com a nomeação, a presidente contemplou uma das seções mais importantes do partido, além de escolher um parlamentar com boa interlocução com o vice-presidente Michel Temer e o pré-candidato petista ao governo mineiro, Fernando Pimentel.

O PMDB conquistou ainda a Secretaria de Aviação Civil, para o qual foi nomeado Moreira Franco, próximo a Michel Temer. O partido manteve as pastas das Minas e Energia, Turismo e Previdência. Também houve substituição no ministério do Trabalho, comandada pelo PDT: saiu Brizola Neto e entrou Manoel Dias, próximo à direção nacional do partido. Além disso, Guilherme Afif Domingos assumiu a recém-criada Secretaria da Micro e Pequena Empresa, em um gesto para prestigiar o PSD no governo. Ao final de 2012, Marta Suplicy (PT) havia assumido o ministério da Cultura. De forma geral, é possível avaliar que as modificações trataram de tentar restabelecer diálogo com os partidos da coalizão ${ }^{85}$. Contudo, as mudanças

\footnotetext{
${ }^{82}$ Com 46 votos, Eduardo Cunha é eleito líder do PMDB na Câmara. Disponível em: http://www1.folha.uol.com.br/poder/2013/02/1225296-com-46-votos-eduardo-cunha-e-eleito-lider-do-pmdb-nacamara.shtml

${ }^{83}$ Congresso derruba veto de Dilma sobre royalties de petróleo. Disponível em: https://oglobo.globo.com/economia/congresso-derruba-veto-de-dilma-sobre-royalties-de-petroleo-7767366

${ }^{84}$ Dilma aumenta peso político do PMDB e amarra PDT ao projeto de reeleição. Disponível em: https://politica.estadao.com.br/noticias/eleicoes,dilma-aumenta-peso-politico-do-pmdb-e-amarra-pdt-ao-projetode-reeleicao-imp-, 1009371

${ }^{85}$ Dilma defende coalização em posse de ministros. Disponível em:

https://politica.estadao.com.br/noticias/eleicoes,dilma-defende-coalizacao-em-posse-de-ministros-imp-,1009755
} 
podem ter sido insuficientes ou terem acontecido tarde demais - poucos meses depois, o governo seria surpreendido pelas manifestações de junho de 2013.

Em maio de 2013, o governo enfrentou nova batalha; desta vez, pela aprovação da Medida Provisória $\mathrm{n}^{\mathrm{o}}$ 595, que alterou as regras para exploração portuária no Brasil. A tramitação na Câmara foi bastante lenta. Eduardo Cunha, líder do PMDB, liderou a resistência à matéria, em aliança com outras lideranças do governo e da oposição. A emenda proposta por ele, em oposição à liderança do governo, foi derrotada por placar apertado - 210 votos a 172. A discussão da matéria no plenário estendeu-se por quase 50 horas. A aprovação no Congresso Nacional ocorreu no prazo limite de a medida perder a validade. As dificuldades para votar uma matéria que somente exigia maioria simples para ser aprovada sinalizou o grau de insatisfação da base aliada com o governo. Ainda assim, o governo conseguiu sair-se vitorioso ${ }^{86}$.

Conforme pode ser observado, até meados de 2013, Dilma Rousseff possuía popularidade elevada e não ocorreram manifestações contra o governo; a economia não dava sinais de desaceleração e ainda não havia eclodido o escândalo do petrolão. No entanto, as condições políticas já indicavam esgarçamento e deterioração na relação entre os partidos da coalizão. Os conflitos advindos da redução do espaço dos partidos aliados no ministério e da demissão de vários ministros já desgastavam a relação entre a presidente e o Congresso desde os primeiros meses de governo. Ao longo do tempo, os conflitos se acirraram. Conforme demonstrado na figura 10, os dados das votações ocorridas no período já mostravam redução do apoio ao governo entre os partidos da coalizão.

Figura 10. Apoio ao Governo na Câmara dos Deputados - Partidos da Coalizão. Governo Dilma I.

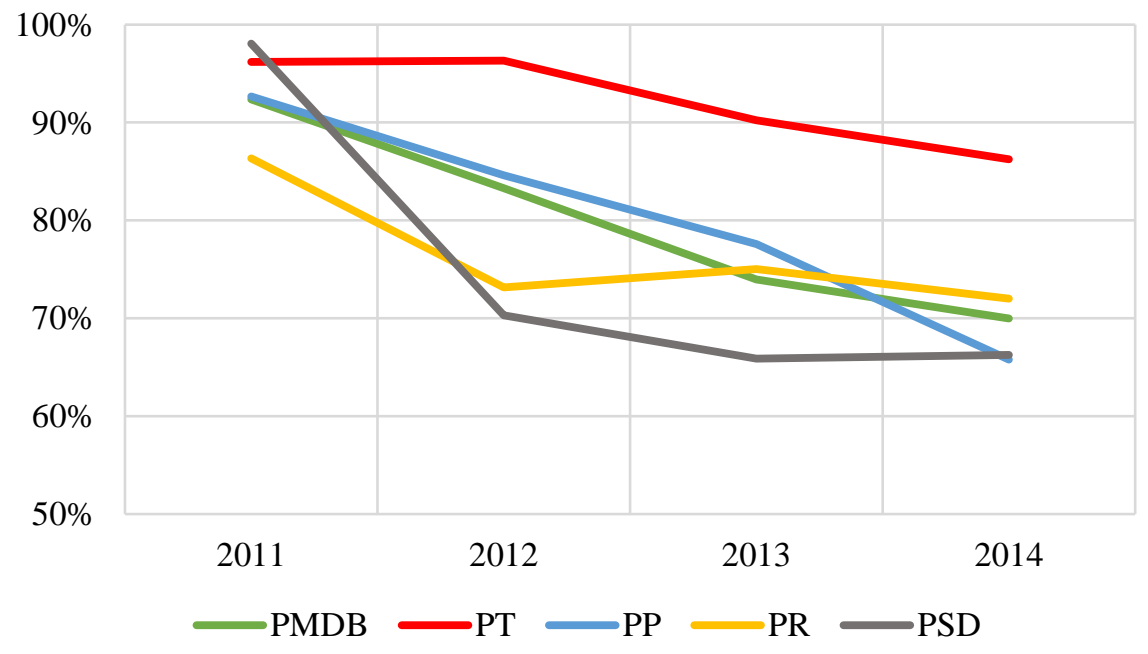

Fonte: Banco de dados do CEBRAP.

\footnotetext{
${ }^{86}$ As quase 50 horas de MP dos Portos na Câmara e no Senado. Disponível em: http://g1.globo.com/politica/noticia/2013/05/quase-50-horas-de-mp-dos-portos-na-camara-e-no-senado.html
} 
Em alguns casos descritos - por exemplo em relação ao novo Código Florestal e à divisão de royalties do petróleo - a derrota do governo era dada como certa; ainda assim, o governo insistiu em contrariar a posição da maior parte dos partidos da base aliada e passar recibo da derrota. A presidente não atuou - ou atuou tardiamente - para aparar arestas entre os partidos governistas. Logo, a construção de escudo legislativo para protegê-la em momentos de crise não aconteceu. As manifestações de junho 2013 reduziriam dramaticamente a popularidade de Dilma Rousseff, tornando-a vulnerável. A presidente poderia aproveitar a ocasião para reconstruir a relação com partidos aliados - como fez Lula quando da eclosão da crise do mensalão. Como se verá a seguir, a oportunidade foi, mais uma vez, desperdiçada.

\subsection{A REELEIÇÃO POR UM TRIZ}

As manifestações de junho de 2013 foram o grande divisor de águas do primeiro governo de Dilma Rousseff. Até então, a presidente gozava de avaliação positiva por parte dos eleitores. Em pesquisa do instituto Datafolha realizada em junho de 2013, antes das manifestações, $57 \%$ dos brasileiros avaliavam o governo positivamente e $9 \%$ o avaliavam negativamente. É importante ressaltar que o segundo semestre de 2012 foi marcado pelo julgamento, televisionado, da ação penal 470 (originada na denúncia do mensalão) pelo Supremo Tribunal Federal ${ }^{87}$. De agosto a dezembro, a Suprema Corte do país se reuniu semanalmente para julgar os envolvidos no escândalo, dentre eles, integrantes da antiga cúpula do PT como José Dirceu e José Genoino. O tribunal acabou por condenar a maior parte dos envolvidos. Mesmo com o julgamento sendo transmitido pelos meios de comunicação, contudo, a popularidade de Dilma Rousseff não foi afetada - ao menos, não inicialmente.

Já os efeitos das manifestações de junho de 2013 se fizeram sentir rapidamente. Logo após os protestos, em julho, a avaliação positiva do governo Dilma Rousseff caiu 27 pontos. A figura 11 ilustra melhor o quadro.

\footnotetext{
${ }^{87}$ O julgamento do mensalão dia a dia. Disponível em: https://www.terra.com.br/noticias/infograficos/mensalao-dia-a-dia/
} 
Figura 11. Avaliação de Governo. Governo Dilma I.

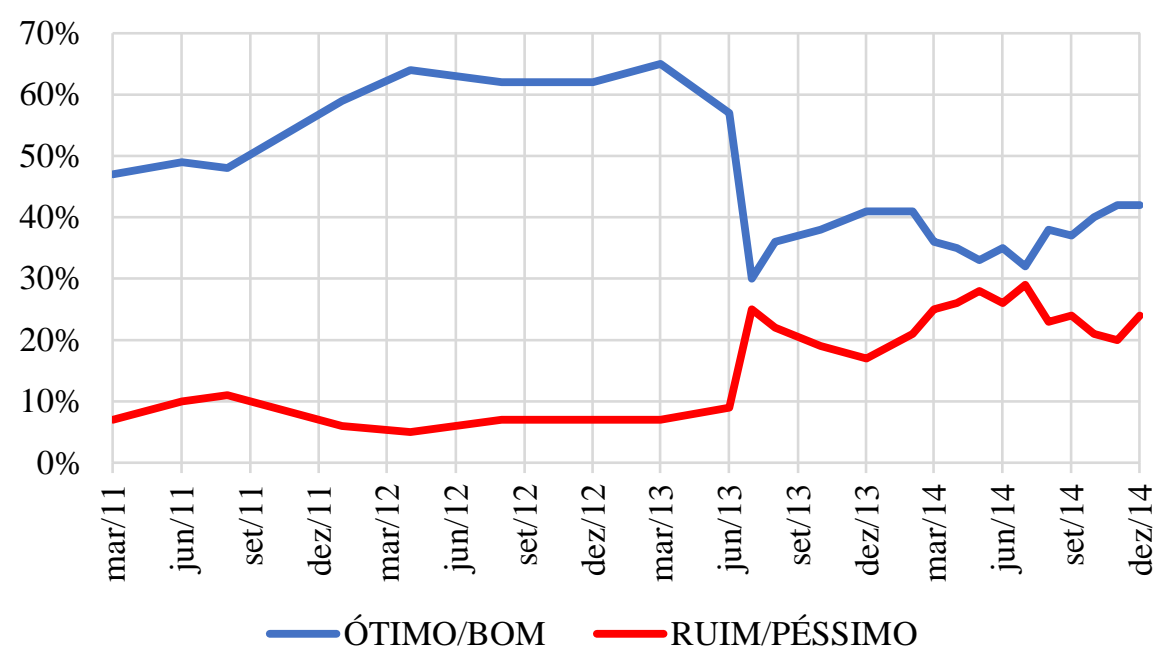

Fonte: Instituto Datafolha.

A compreensão dos fatos que levaram à realização das amplas manifestações é tarefa complexa, que foge ao escopo deste trabalho. O que se pode dizer a respeito é que as manifestações tiveram início em São Paulo após aumento de 20 centavos no preço da tarifa de ônibus e se disseminaram por todo o país. Houve ampla participação popular, mas sem pauta específica. Cobrava-se a melhoria dos serviços públicos e o combate à corrupção. É possível que o contexto de crescimento econômico mais lento tenha propiciado a ocorrência dos atos, que desgastou governantes em diferentes esferas, não só no âmbito federal.

Nesse sentido, Ângela Alonso (2018) conduziu amplas pesquisas sobre junho de 2013. A autora identifica diversos grupos e pautas que estiveram presentes nas ruas do país naquele momento e afirma que:

Diante de um monte de bandeiras nas ruas, o que agregou aqueles que queriam menos Estado, menos burocracia, menos político e menos PT foi a agenda da corrupção. É por isso que podemos ver como junho estruturou o que está acontecendo até agora no Brasil: a agenda da corrupção e a própria solução do impeachment fazem parte do conjunto de elementos recuperados dos movimentos do passado (ALONSO, 2018).

Em suma, é possível identificar em junho de 2013 a origem da pauta anticorrupção, que viria a ocupar papel cada vez mais relevante na agenda política, sobretudo, posteriormente, com o avanço da Operação Lava-Jato.

Em resposta às reivindicações dos manifestantes, Dilma Rousseff propôs pacto nacional com governadores e prefeitos para garantir a responsabilidade fiscal e controle da inflação e realizar investimentos em saúde, educação e transportes. A proposta mais controversa, contudo, 
foi a convocação de plebiscito para formação de constituinte exclusiva para implementar a reforma política ${ }^{88}$.

A proposta de plebiscito foi criticada por partidos aliados e boa parte das demais proposições acabaram por não se concretizar. As manifestações cessaram e gradualmente o governo conseguiu recuperar sua avaliação - embora jamais em níveis anteriores a junho de 2013. A criação do Programa Mais Médicos, por meio de medida provisória, foi encaminhada ao Congresso nesse contexto. A votação da medida, contudo, foi alvo de embate entre o PT e aliados - a tramitação ocorreu de modo simultâneo à discussão da reforma política, tema de divergência dentro da coalizão de governo ${ }^{89}$. Enquanto o PT e os demais partidos de esquerda defendiam aprovação de reforma mais ampla, a proposta do PMDB e de outros partidos da base era por uma minirreforma eleitoral. Em outubro, o Congresso aprovou a criação do Programa Mais Médicos. Em relação à reforma política, prevaleceu a proposição do PMDB, contrária à realização de alterações mais profundas nas regras eleitorais.

O caso da reforma política é mais um exemplo de como o Executivo acabou por se distanciar dos partidos da coalizão. A proposta de Dilma Rousseff de plebiscito e constituinte já havia sido criticada; contudo, o PT insistiu em propor reforma política ampla - o que não era do agrado do Congresso Nacional e dos partidos da coalizão naquele momento. Além disso, a posição do PT acabou por definir o encaminhamento adotado pela liderança do governo, o que contrariou os demais partidos da base governista. Nesse contexto, abriu-se o espaço para a atuação do líder do PMDB, Eduardo Cunha.

À época, o PMDB era o maior partido da coalizão e detinha a vice-presidência da República e as presidências da Câmara e do Senado. A ascensão de Cunha à liderança da bancada somente se tornou possível em razão da insatisfação dos peemedebistas em relação ao governo - à época, no início de 2013, todos os candidatos ao cargo de líder expuseram o descontentamento e defenderam posição de independência em relação ao Palácio do Planalto ${ }^{90}$. O PMDB foi o partido que mais perdeu espaço quando Dilma Rousseff foi eleita. Com o passar do tempo e conforme descrito anteriormente, a insatisfação atingiu também os demais partidos

\footnotetext{
${ }^{88}$ Dilma propõe 5 pactos e plebiscito para constituinte da reforma política. Disponível em: http://g1.globo.com/politica/noticia/2013/06/dilma-propoe-5-pactos-e-plebiscito-para-constituinte-da-reformapolitica.html

${ }^{89}$ PMDB promete obstrução à MP do Mais Médicos até minirreforma eleitoral ser votada. Disponível em: http://www.ebc.com.br/noticias/politica/2013/10/pmdb-promete-obstrucao-a-mp-do-mais-medicos-ateminirreforma-eleitoral-ser

${ }^{90}$ Eduardo Cunha (RJ) é eleito para a liderança do PMDB na Câmara. Disponível em:

https://www.valor.com.br/politica/2993906/eduardo-cunha-rj-e-eleito-para-lideranca-do-pmdb-na-camara
} 
da coalizão, oportunidade que Cunha soube aproveitar para se aproximar dos demais líderes governistas.

A coalizão de governo perdeu, em setembro de 2013, o apoio do PSB. O partido entregou os cargos no governo - dentre eles, os ministérios da Integração Nacional e dos Portos - e se empenhou em articular a candidatura do governador de Pernambuco, Eduardo Campos, à presidência da República ${ }^{91}$. A decisão não foi seguida pelos irmãos Ciro e Cid Gomes, que permaneceram aliados ao Palácio do Planalto e se filiaram ao recém-criado PROS ${ }^{92}$. Contudo, poucos parlamentares do PSB seguiram os irmãos Gomes em direção ao novo partido. A saída do PSB da base acabou por suscitar a cobiça dos partidos da coalizão pelos cargos deixados pelo partido - sobretudo pela pasta da Integração Nacional. Dilma Rousseff, no entanto, optou por manter os cargos outrora ocupados pelo PSB com aliados da família Gomes e do PROS ${ }^{93}$. Em suma, a saída do PSB da coalizão acabou por não beneficiar os demais partidos aliados, que não conseguiram aumentar sua participação no governo.

O ano de 2014 foi marcado por relação ainda mais conflituosa entre Dilma Rousseff e a coalizão. O líder do PMDB organizou, ao lado do PP e de outras siglas aliadas, a criação de bloco partidário com objetivo de aumentar o poder de negociação em relação ao governo federal ${ }^{94}$. Além dos conflitos listados anteriormente, também havia descontentamento dos parlamentares em relação ao pagamento de emendas e ao encaminhamento pelo Executivo de projetos com urgência constitucional, que trancam a pauta do Congresso. A situação é ilustrativa acerca da capacidade da interlocução do líder do PMDB com lideranças de outros partidos e, mais ainda, do isolamento a que o PT foi submetido - ou se submeteu. Nos primeiros meses do ano, o Executivo sofreu derrotas, capitaneadas pelo líder do PMDB.

O Palácio do Planalto atuou para implodir o bloco partidário idealizado por Cunha. Para tanto, o governo aproximou-se das cúpulas dos partidos da coalizão, como o PP e o PSD, com objetivo de contrabalançar o movimento do PMDB e esvaziar o bloco liderado pelo partido ${ }^{95}$.

\footnotetext{
${ }^{91}$ PSB deixa governo Dilma e dá primeiro passo para candidatura de Campos. Disponível em: http://www.gazetadopovo.com.br/vida-publica/psb-deixa-governo-dilma-e-da-primeiro-passo-para-candidaturade-campos-cb60536384rdsglp43ghami4u

${ }_{92}$ Depois de deixarem o PSB, Cid e Ciro Gomes anunciam filiação ao PROS. Disponível em:

https://politica.estadao.com.br/noticias/geral,depois-de-deixarem-o-psb-cid-e-ciro-gomes-anunciam-filiacao-aopros, 1081157

${ }^{93}$ Nomeação de ministro interino irrita PMDB. Disponível em: https://exame.abril.com.br/brasil/nomeacao-de-ministro-interino-irrita-pmdb/

${ }^{94}$ Líderes da base anunciam criação de 'superbloco' para pressionar Dilma. Disponível em: http://g1.globo.com/politica/noticia/2014/02/lideres-da-base-anunciam-criacao-de-superbloco-para-pressionardilma.html

${ }^{95}$ Governo corteja aliados para anular formação de 'blocão'. Disponível em: http://politica.estadao.com.br/noticias/eleicoes, governo-corteja-aliados-para-anular-formacao-de-blocao-imp, 1138103
} 
O governo aproveitou para isso a reforma ministerial, realizada entre março e abril de 2014 . O presidente do PP, Ciro Nogueira, por exemplo, foi contemplado com a indicação do novo ministro das Cidades, Gilberto Occhi. Dilma Rousseff anunciou ainda mudanças da Casa Civil e na Secretaria de Relações Institucionais. Saíram Gleisi Hoffmann e Ideli Salvatti e entraram Aloizio Mercadante e Ricardo Berzoini. Ainda assim, o governo enfrentou dificuldades para aprovar o marco civil da internet ${ }^{96}$ e assistiu à convocação pela Câmara dos Deputados de dez ministros para prestarem esclarecimentos ${ }^{97}$.

A partir da reforma ministerial, os esforços do governo foram dedicados à construção da coligação eleitoral de Dilma Rousseff. Eduardo Cunha sugeriu que o PMDB repensasse a aliança formal com o $\mathrm{PT}^{98} \mathrm{e}$ anunciou que a bancada na Câmara não indicaria substitutos para os ministros da Agricultura e do Turismo, já que os titulares - Antônio Andrade e Gastão Vieira, respectivamente - deixariam seus cargos para serem candidatos nas eleições de outubro de 2014. Os deputados do partido aprovaram ainda moção de solidariedade a Cunha ${ }^{99}$. As lideranças do PMDB no Senado também manifestaram insatisfação com o PT e o governo. O descontentamento atingiu ainda a seção fluminense do partido em razão do lançamento da candidatura a governador de Lindberg Farias (PT) contra a tentativa de reeleição de Luiz Fernando Pezão (PMDB). Dilma Rousseff chegou a pedir ajuda de seu antecessor Luiz Inácio Lula da Silva, que viajou a Brasília para conversar com os peemedebistas ${ }^{100}$.

Ao contrário das eleições de 2010 - nas quais o PT abriu mão de lançar candidatos a governos estaduais para obter o apoio de aliados nas eleições presidenciais -, em 2014, o PT lançou candidaturas aos governos dos principais estados do país. Em 2010, por exemplo, o PT apoiou candidatos a governador do PMDB em Minas Gerais e no Rio de Janeiro, como contrapartida ao apoio dos peemedebistas à eleição de Dilma Rousseff; já, em 2014, o PT lançou candidaturas próprias nos dois estados.

\footnotetext{
${ }^{96}$ Planalto negocia com PMDB saída para votar lei da internet. Disponível em: https://www1.folha.uol.com.br/poder/2014/03/1427039-planalto-negocia-com-pmdb-saida-para-votar-lei-dainternet.shtml

97 "Blocão" impõe nova derrota ao governo e convoca dez ministros. Disponível em:

http://www.gazetadopovo.com.br/vida-publica/blocao-impoe-nova-derrota-ao-governo-e-convoca-dez-ministros$1 \mathrm{tf} 6 \mathrm{~d} 3 \mathrm{~mm} 0 \mathrm{gq} 95 \mathrm{yfhao60 \textrm {ke } 1 \mathrm { ji }}$

${ }^{98}$ Pelo twitter, Eduardo Cunha diz que é preciso repensar aliança do PMDB com PT. Disponível em: https://jornalggn.com.br/noticia/pelo-twitter-eduardo-cunha-diz-que-e-preciso-repensar-alianca-do-pmdb-com-pt

${ }^{99}$ Bancada do PMDB aprova moção de solidariedade e defende Eduardo Cunha. Disponível em: http://www2.camara.leg.br/camaranoticias/noticias/politica/463426-bancada-do-pmdb-aprova-mocao-desolidariedade-e-defende-eduardo-cunha.html

${ }^{100}$ Lula tenta consolidar aliança de Dilma, mas PMDB ameaça levar crise ao Senado. Disponível em: http://politica.estadao.com.br/noticias/geral,lula-tenta-consolidar-alianca-de-dilma-mas-pmdb-ameaca-levarcrise-ao-senado, 1137585
} 
O rompimento da aliança entre as duas legendas no Rio de Janeiro - principal estado governado por peemedebistas - irritou a seção fluminense do partido, que, em retaliação, apoiou a candidatura presidencial de Aécio Neves, do PSDB ${ }^{101}$. Outro estado em que a decisão do PT local viria a ter implicações nacionais foi o Rio Grande do Norte, no qual o então presidente da Câmara dos Deputados, Henrique Eduardo Alves, acabou derrotado em sua candidatura a governador - o PT integrou a chapa de oposição ${ }^{102}$.

A decisão do PT de investir em candidaturas próprias e enfrentar seu principal parceiro de coalizão nas disputas estaduais não faz sentido ao se analisar o cenário político da época. Como dito anteriormente, em 2010, mesmo diante da popularidade de Lula e do crescimento econômico, o partido fez diversas concessões a partidos aliados. Em 2014, o cenário político se apresentava muito mais desafiador ao PT. A popularidade de Dilma Rousseff, embora em recuperação, encontrava-se na casa dos $30 \%$ - bastante inferior ao patamar existente antes das manifestações de junho de 2013. Além disso, a antiga cúpula do PT havia sido condenada pelo Supremo Tribunal Federal no julgamento do mensalão e alguns de seus integrantes, como o exministro José Dirceu, estavam presos.

Diante desse quadro, parece arriscada a estratégia do PT de insistir em projetos regionais e entrar em conflito com aliados. A única explicação plausível seria uma avaliação de que o partido poderia dispensar o apoio de aliados nas eleições, que os resultados eleitorais de 2014 lhe seriam bastante favoráveis e que, em eventual segundo mandato de Dilma Rousseff, conseguiria diminuir sua dependência em relação ao PMDB e demais integrantes da coalizão. Tal análise soa um tanto otimista ao considerar os aspectos elencados acima. Contudo, em entrevista ao final de 2013, João Santana, publicitário responsável pela campanha de reeleição de Dilma Rousseff, apostava em uma vitória em primeiro turno (algo que o PT não havia obtido em nenhuma disputa presidencial), mesmo após as manifestações de junho de 2013 e a queda na popularidade da presidente ${ }^{103}$.

No caso das alianças regionais, não se pode responsabilizar somente a presidente Dilma Rousseff pela estratégia política do PT. A decisão do partido de não apoiar os candidatos do

${ }^{101}$ PMDB do Rio lança chapa 'Aezão' contra Dilma. Disponível em: https://www1.folha.uol.com.br/poder/2014/04/1440819-pmdb-do-rio-lanca-chapa-aezao-contra-dilma.shtml ${ }_{102}$ Vice-governador supera Henrique Alves e vence no RN. Disponível em: https://www1.folha.uol.com.br/poder/2014/10/1538707-vice-governador-supera-henrique-alves-e-vence-norn.shtml

${ }^{103}$ João Santana, o homem que elegeu seis presidentes. Disponível em:

https://epoca.globo.com/tempo/noticia/2013/10/bjoao-santanab-o-homem-que-elegeu-seis-presidentes.html 
PMDB no Rio de Janeiro ${ }^{104}$ e no Rio Grande do Norte ${ }^{105}$ contou com o respaldo do expresidente Lula, por exemplo. A decisão do PT viria a ter reflexos na relação com os aliados mesmo após as eleições, conforme se verá no capítulo seguinte.

Além da queda em sua popularidade e da dificuldade na relação com aliados, a presidente Dilma Rousseff enfrentaria ainda a pressão para que abdicasse de sua candidatura à reeleição em favor de uma candidatura presidencial de Lula ${ }^{106}$. A sugestão partiu de setores do empresariado e de políticos descontentes com a condução política de Dilma Rousseff. Lula, no entanto, optou por não arriscar seu patrimônio político em uma disputa eleitoral que poderia ser acirrada.

Dessa forma, com apoio de Mercadante e Berzoini, Dilma tratou de negociar com os partidos aliados a participação em sua coligação eleitoral. O PSD foi o primeiro partido a apoiar oficialmente a reeleição. Conforme afirmou o presidente do partido, Gilberto Kassab, o apoio era um gesto de agradecimento ao governo pelo suporte empreendido na fundação do partido. O PROS anunciou apoio ao PT, pelas mesmas razões. A convenção do PP foi bastante tumultuada e foi preciso intervenção do presidente do partido, Ciro Nogueira, para que o apoio a Dilma fosse formalizado ${ }^{107}$. O PMDB aprovou o apoio em uma convenção dividida, com placar apertado: $59 \%$ dos convencionais votaram a favor da reedição da aliança ${ }^{108}$. A intervenção do vice-presidente Michel Temer foi fundamental para o resultado ${ }^{109}$. Ainda assim, houve dissidências importantes, como no caso do diretório do Rio de Janeiro. Em relação ao PR, a coligação só foi firmada após a troca no ministério dos Transportes - o partido estava insatisfeito com o desempenho do ministro César Borges ${ }^{110}$. O PDT e o PCdoB, mais alinhados ideologicamente ao PT, também formalizaram apoio à presidente. Ao final, Dilma Rousseff

\footnotetext{
${ }^{104}$ Lula vê candidatura de Lindbergh no RJ como irreversível. Disponível em: https://congressoemfoco.uol.com.br/especial/noticias/lula-ve-candidatura-de-lindbergh-no-rj-como-irreversivel/ ${ }_{105}$ Com apoio do PT, Robinson Faria (PSD) é eleito governador no RN. Disponível em: https://istoe.com.br/389558 com+apoio+do+pt+robinson+faria+psd+e+eleito+governador+no+rn/ ${ }^{106}$ Cresce o movimento "volta Lula", mas o ex-presidente nega candidatura. Disponível em: https://brasil.elpais.com/brasil/2014/04/09/politica/1397000108_059210.html

${ }_{107}$ Após ser chamado de 'vendido', Nogueira aprova apoio a Dilma em reunião secreta da Executiva do PP. Disponível em: https://oglobo.globo.com/brasil/apos-ser-chamado-de-vendido-nogueira-aprova-apoio-dilma-emreuniao-secreta-da-executiva-do-pp-13013800

108 Apesar de ala dissidente, PMDB aprova apoio a Dilma nas eleições. Disponível em: http://g1.globo.com/distrito-federal/eleicoes/2014/noticia/2014/06/apesar-de-ala-dissidente-pmdb-aprova-apoiodilma-nas-eleicoes.html

${ }^{109}$ Dilma agradece ao PMDB e elogia Michel Temer por articular apoio. Disponível em: http://g1.globo.com/distrito-federal/eleicoes/2014/noticia/2014/06/dilma-agradece-ao-pmdb-e-elogia-micheltemer-por-articular-apoio.html

110 Para manter aliança com o PR, Dilma troca ministro dos Transportes. Disponível em: https://oglobo.globo.com/brasil/para-manter-alianca-com-pr-dilma-troca-ministro-dos-transportes-13009662
} 
conseguiu formar coligação eleitoral bastante robusta, com apoio de PT, PMDB, PP, PR, PSD, PROS, PDT e PCdoB.

A presidente Dilma Rousseff foi reeleita no pleito presidencial mais disputado desde a redemocratização, com apoio de 51,6\% dos eleitores. Contudo, a reeleição não marcaria a redução dos conflitos entre os partidos da coalizão. O bloco partidário formado anteriormente por Eduardo Cunha voltou a atuar de forma conjunta, logo após a proclamação do resultado eleitoral.

O segundo turno da eleição ocorreu em 26 de outubro de 2014. Na terça-feira seguinte, 28 de outubro, o governo foi derrotado na primeira votação realizada pelo Congresso após a reeleição de Dilma Rousseff. A Câmara dos Deputados derrubou o decreto presidencial que instituiu a Política Nacional de Participação Social, os chamados conselhos populares. A votação foi simbólica e uniu a oposição e a maior parte da base aliada. Somente PT, PCdoB e PSOL defenderam o decreto presidencial ${ }^{111}$.

No dia seguinte, o PMDB reconduziu Eduardo Cunha à liderança da bancada. O partido deu início às tratativas para construção de sua candidatura à presidência da Câmara para o biênio 2015-2016 ${ }^{112}$. O deputado organizou a formação de bloco com legendas governistas e da oposição para isolar o PT na Casa ${ }^{113}$.

A votação do projeto de lei que alterou a LDO para revisar a meta fiscal de 2014 foi aprovada após 18 horas de discussão, com apoio de 240 deputados e 39 senadores. Com a aprovação, o governo ficou desobrigado de cumprir a meta de superávit primário estipulada. A oposição aproveitou a ocasião para criticar duramente a presidente da República e o desequilíbrio fiscal do país ${ }^{114}$.

Por fim, em uma das últimas votações de 2014, a Câmara aprovou em primeiro turno a PEC do Orçamento Impositivo, que estabeleceu a execução obrigatória das emendas

\footnotetext{
${ }^{111}$ Deputados derrubam decreto dos conselhos populares. Disponível em: http://www2.camara.leg.br/camaranoticias/noticias/politica/476677-deputados-derrubam-decreto-dos-conselhospopulares.html

${ }_{112}$ PMDB autoriza Eduardo Cunha a formar bloco para viabilizar eleição dele à presidência da Câmara. Disponível em: https://oglobo.globo.com/brasil/pmdb-autoriza-eduardo-cunha-formar-bloco-para-viabilizareleicao-dele-presidencia-da-camara-14399894

${ }^{113}$ Cunha reúne 'blocão' para tentar isolar PT na Câmara. Disponível em:

http://www1.folha.uol.com.br/poder/2014/11/1542321-cunha-reune-blocao-para-tentar-isolar-pt-nacamara.shtml

${ }^{114}$ Congresso aprova mudança na meta fiscal de 2014, após 18 horas. Disponível em: http://www.valor.com.br/politica/3804386/congresso-aprova-mudanca-na-meta-fiscal-de-2014-apos-18-horas
} 
parlamentares. A votação foi articulada pelo então presidente da Câmara, Henrique Eduardo Alves (PMDB), e pelo líder do PMDB e aspirante à sua sucessão, Eduardo Cunha ${ }^{115}$.

A figura 12, abaixo, deixa mais evidente a queda do apoio ao governo entre os partidos da coalizão durante o primeiro mandato de Dilma Rousseff. É possível notar que a redução do apoio ao governo ocorre em todos os partidos, até mesmo no PT. No PMDB e no PP, a queda é constante ao longo de todo o primeiro mandato. No PR, a queda é mais expressiva no começo do mandato, quando o partido adotou posição de independência após a demissão do presidente nacional da legenda do ministério dos Transportes. A posição do PSB tem relação com o rompimento do partido com o governo em 2013. Também houve redução no apoio do PSD. A queda de apoio ao governo entre os partidos da coalizão durante o mandato de Dilma Rousseff fica mais clara quando os dados são comparados aos do governo Lula. Em nenhum momento, sob a presidência de Lula, o apoio ao governo ficou abaixo de $80 \%$, nem mesmo durante a crise do mensalão, em 2005. No segundo mandato de Dilma Rousseff, os conflitos entre a presidente e o Congresso atingirão níveis dramáticos, como será exposto no capítulo seguinte.

Figura 12. Apoio ao Governo na Câmara dos Deputados - Partidos da Coalizão. Governos Lula e Dilma I.

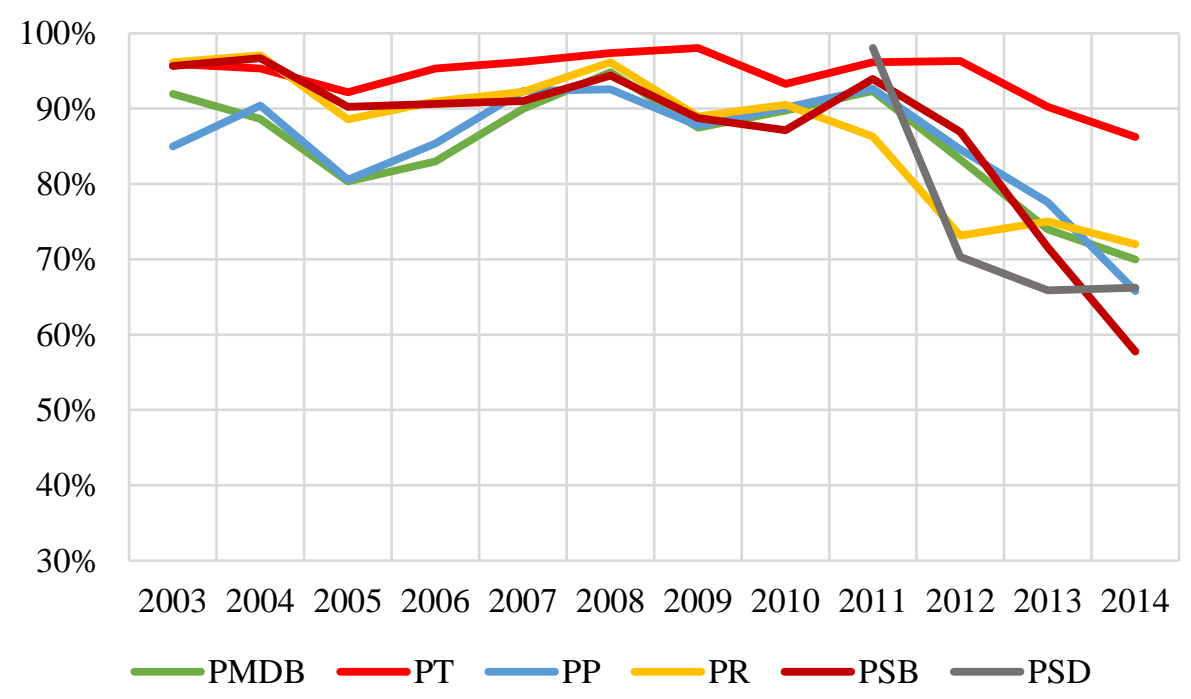

Fonte: Banco de dados do CEBRAP.

115 Câmara aprova PEC do orçamento impositivo em $1^{\circ}$ turno. Disponível em: http://www2.camara.leg.br/camaranoticias/noticias/politica/479575-camara-aprova-pec-do-orcamentoimpositivo-em-1-turno.html 


\section{DILMA II: A DERROCADA}

\subsection{O NOVO MINISTÉRIO}

Dilma Rousseff tomou posse para seu segundo mandato em $1^{\circ}$ de janeiro de 2015 . A presidente manteve Aloizio Mercadante (PT) como ministro-chefe da Casa Civil. Na pasta de Relações Institucionais foi nomeado Pepe Vargas (PT), em substituição a Ricardo Berzoini (PT), deslocado para a pasta de Comunicações. Na Secretaria Geral, Miguel Rossetto (PT) substituiu Gilberto Carvalho (PT), que era bastante ligado ao ex-presidente Lula. Jaques Wagner, ex-governador da Bahia, assumiu o ministério da Defesa.

Em relação à área econômica, Guido Mantega deixou o ministério da Fazenda, sendo substituído por Joaquim Levy, que assumiu com a expectativa de realizar ajuste fiscal nas contas públicas brasileiras. No Planejamento, foi nomeado Nelson Barbosa, de uma linha econômica mais heterodoxa que o novo titular da Fazenda.

O PMDB ficou com seis pastas. No ministério da Agricultura, assumiu a senadora Kátia Abreu, recém-filiada ao partido. Nas Minas e Energia, Edison Lobão deu lugar a Eduardo Braga, ambos com mandato no Senado. Na Pesca, foi nomeado Helder Barbalho, filho do senador Jader Barbalho. O Turismo foi mantido com Vinicius Lages, ligado ao presidente do Senado, Renan Calheiros. A pasta dos Portos ficou com Edinho Araújo e a Aviação Civil com Eliseu Padilha - ambos próximos ao vice-presidente Michel Temer. Em suma, o PMDB continuou sub-representado no ministério - nenhuma das pastas destinadas ao partido possuía grande espaço para realização de investimentos. Contudo, desta vez, a bancada de deputados do PMDB teve pouquíssima participação na composição ministerial, em razão da relação tumultuada entre a presidente e Eduardo Cunha, líder da bancada na Câmara.

Em relação aos demais partidos aliados, o PP perdeu a pasta das Cidades e foi contemplado com a Integração Nacional - uma troca que não agradou a legenda. O PSD conseguiu emplacar Gilberto Kassab no ministério das Cidades, um dos mais cobiçados pela classe política. O PR manteve o ministério dos Transportes. O PDT manteve o Trabalho. Já o PCdoB perdeu a pasta de Esportes para o PRB, que havia aumentado sua bancada na última eleição, e foi compensado com a Ciência e Tecnologia. O PROS conquistou o cobiçado ministério da Educação, com o ex-governador Cid Gomes - anteriormente ocupado pelo PT. A Saúde foi mantida com o partido da presidente, como ocorreu durante toda a primeira gestão de Dilma Rousseff. Os destaques, nesse caso, ficaram por conta das pastas destinadas ao PSD e ao PROS, partidos recém-criados e que gozavam de prestígio diante da presidente, sobretudo no 
contexto de desgaste com o PMDB ${ }^{116}$. Como pode ser visto na figura 13, PSD e PROS passaram a ser responsáveis por parcela importante dos investimentos do governo federal. A redução do espaço do PT se explica sobretudo em razão de ter perdido o comando do ministério da Educação.

Figura 13. Investimentos dos Ministérios - Por Partido. Governo Dilma 2011-15.

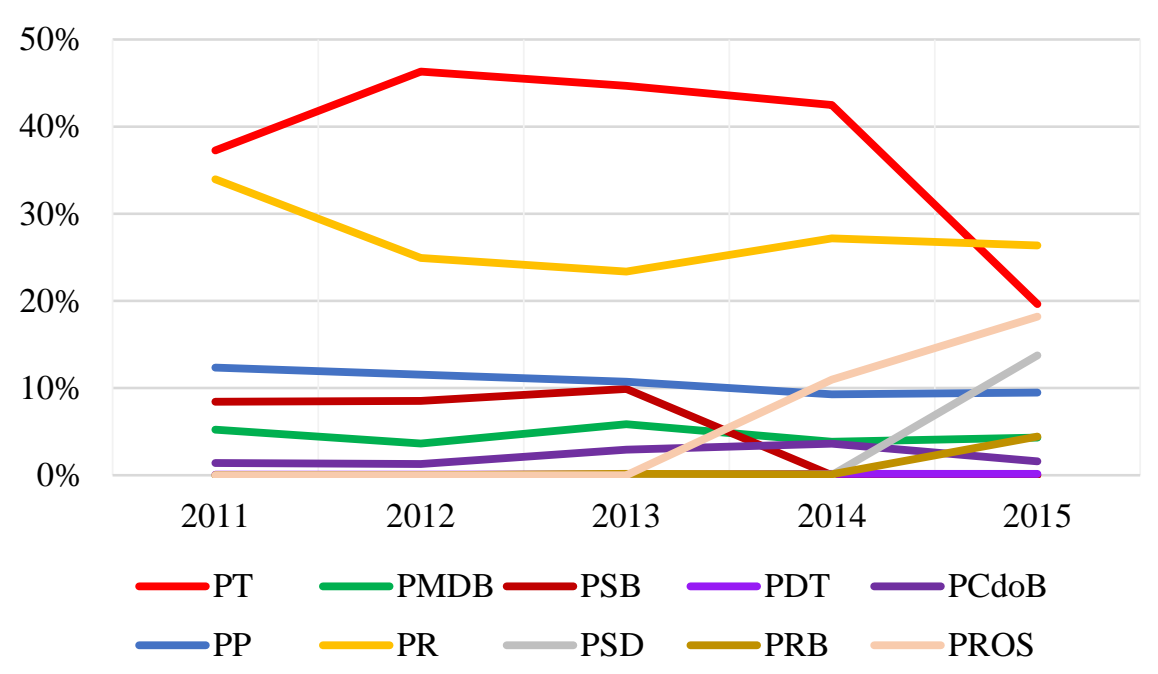

Fonte: Banco de dados do SIAFI. Valor empenhado, em porcentagem.

\subsection{A ELEIÇÃO DE EDUARDO CUNHA}

Em janeiro de 2015, Eduardo Cunha consolidou aliança com uma dezena de partidos, de modo a viabilizar sua candidatura à presidência da Câmara dos Deputados. O líder do PMDB formou bloco com 14 legendas, dentre as quais o PP e o PRB, além de outras siglas menores e outras de oposição ${ }^{117}$. O PT lançou a candidatura do ex-líder do governo, Arlindo Chinaglia, e conseguiu apoio do PROS, do PCdoB, do PSD e do PR. O bloco do PMDB reuniu apoio de 218 deputados; enquanto o bloco do PT reuniu apoio de 160. Contudo, embora Chinaglia tivesse obtido o apoio do PSD e do PR, por exemplo, Cunha possuía relações estreitas com parlamentares dessas siglas. O PR chegou a integrar o bloco do PMDB, mas mudou de posição ao longo do processo. O partido, assim como PSD e o PROS, estava bem representado no ministério; já o PP e, sobretudo, o PMDB estavam sub-representados. Cunha soube trabalhar a

\footnotetext{
${ }^{116}$ Dilma nomeia Kassab e mais 12 para acomodar aliados no novo Governo. Disponível em: https://brasil.elpais.com/brasil/2014/12/23/politica/1419358115 778828.html

${ }^{117}$ Eduardo Cunha vai para eleição com maioria de partidos. Disponível em:

http://politica.estadao.com.br/noticias/geral,eduardo-cunha-vai-para-eleicao-com-maioria-de-partidos, 1627932
} 
insatisfação dos partidos da coalizão para viabilizar sua candidatura ${ }^{118}$. Na eleição, o líder do PMDB obteve 267 votos contra 136 do candidato do PT, o que leva à conclusão de que muitos parlamentares de partidos que formalmente apoiaram Chinaglia votaram em Eduardo Cunha ${ }^{119}$. O placar de 136 votos obtidos pelo governo na eleição para presidência da Câmara foi praticamente idêntico ao obtido quando da análise do impeachment de Dilma Rousseff.

O novo presidente da Câmara elegeu-se em primeiro turno, contra o PT e o governo federal e com o apoio de governistas insatisfeitos e da oposição. No Senado, Renan Calheiros (PMDB) foi reeleito presidente. Assim, o PMDB manteve as presidências das duas Casas Legislativas e a vice-presidência da República durante o biênio 2015-2016. Se o partido estava desprestigiado em relação ao ministério, o mesmo não se pode dizer em relação ao Poder Legislativo. Em propaganda política veiculada ao final de fevereiro, o PMDB marcou distanciamento em relação ao Palácio do Planalto, com o lema "não são as estrelas que vão me guiar; são as escolhas que vão me levar" - o símbolo do PT é uma estrela vermelha. O vicepresidente Michel Temer obteve bastante destaque durante a propaganda do partido ${ }^{120}$.

Um dos primeiros projetos aprovados pela Câmara na gestão de Eduardo Cunha (PMDB) foi o que dificultou a fusão de partidos: a partir de então, uma nova legenda necessitaria esperar cinco anos para se fundir a outra ${ }^{121}$. A aprovação do projeto foi uma reação do PMDB e de outros partidos da coalizão à iniciativa de Gilberto Kassab de criar uma nova sigla, o PL, e depois efetuar a fusão com o PSD - o que permitiria a migração de parlamentares para a nova sigla sem ferir a lei da fidelidade partidária. A legislação eleitoral prevê a perda de mandato para quem mudar de legenda sem justificativa, salvo em caso de partidos novos ou fusões. O movimento de Kassab poderia enfraquecer o PMDB e outros partidos da base aliada. O Senado, sob o comando de Renan Calheiros (PMDB), aprovou em tempo célere o projeto $^{122}$. Contudo, Dilma Rousseff sancionou-o no prazo limite permitido pela legislação e Kassab

\footnotetext{
${ }^{118}$ Eduardo Cunha deve vitória a Dilma. Disponível em: http://www.blogdokennedy.com.br/eduardo-cunha-deve-vitoria-a-dilma/ ${ }^{119}$ Eduardo Cunha é eleito presidente da Câmara dos Deputados. Disponível em: http://www2.camara.leg.br/camaranoticias/noticias/politica/481104-eduardo-cunha-e-eleito-presidente-dacamara-dos-deputados.html ${ }^{120}$ PMDB coloca Dilma contra a parede de olho em cargos e em 2018. Disponível em: https://brasil.elpais.com/brasil/2015/02/25/politica/1424904841_410520.html

${ }^{121}$ Câmara aprova projeto de lei que dificulta a fusão de partidos. Disponível em: http://g1.globo.com/politica/noticia/2015/02/camara-aprova-projeto-de-lei-que-dificulta-fusao-de-partidos.html ${ }^{122}$ Senado aprova projeto que impede fusão de partidos recém-criados. Disponível em: http://g1.globo.com/politica/noticia/2015/03/senado-aprova-projeto-que-impede-fusao-de-partidos-recemcriados.html
} 
conseguiu protocolar o pedido de criação do PL no TSE a tempo de a nova lei entrar em vigor. A relação entre a presidente e o PMDB deteriorou-se ainda mais ${ }^{123}$.

Nesse sentido, o desgaste entre o PMDB e o governo não ficou restrito à Câmara dos Deputados. Renan Calheiros já havia defendido que Michel Temer deveria desempenhar papel mais atuante no governo. No começo de março, o presidente do Senado devolveu a medida provisória da reoneração - aumento da contribuição previdenciária para as empresas - alegando inconstitucionalidade $^{124}$. O tema era tratado como prioritário pela equipe econômica. Dilma Rousseff enviou, em seguida, ao Congresso um projeto de lei sobre o tema, que não chegou a ser apreciado.

Ainda em março, a Câmara aprovou em segundo turno a PEC do Orçamento Impositivo, que tornou obrigatória a execução de emendas parlamentares ${ }^{125}$. A emenda foi promulgada em seguida, em uma nova derrota do governo. No mesmo mês, o ministro da Educação, Cid Gomes (PROS) protagonizou embate público com Eduardo Cunha e o PMDB, acusando-os de achacadores. O ministro foi convocado à Câmara para prestar esclarecimento e manteve as acusações. Mais ainda, disse que os partidos aliados deveriam escolher entre defender ou deixar o governo - "largar o osso", em suas palavras. Cunha exigiu do governo a demissão imediata do ministro e foi atendido - no mesmo dia, o ministro foi substituído. O episódio mostrou a força do presidente da Câmara ${ }^{126}$. Nesse contexto, Eduardo Cunha propôs ainda a redução do número de ministérios - de 39 para 20 - em tentativa de estabelecer diálogo com a opinião pública e desgastar o governo, que se recusava a diminuir a equipe ministerial ${ }^{127}$.

\subsection{AS MANIFESTAÇÕES DE MARÇO DE 2015}

Em 15 de março, amplas manifestações contra a presidente aconteceram nas ruas do país $^{128}$. A economia dava sinais negativos, em meio a um déficit fiscal crescente e a medidas

\footnotetext{
${ }^{123}$ Novo partido de Kassab amplia crise entre Dilma e PMDB. Disponível em: https://www.terra.com.br/noticias/brasil/politica/novo-partido-de-kassab-amplia-crise-entre-dilma-epmdb,1c83ffb11265c410VgnVCM10000098cceb0aRCRD.html

${ }^{124}$ PMDB desafia Dilma e devolve projeto que prevê ajuste fiscal. Disponível em: https://brasil.elpais.com/brasil/2015/03/03/politica/1425423072_653232.html

${ }^{125}$ Promulgada emenda constitucional do orçamento impositivo. Disponível em:

http://www2.camara.leg.br/camaranoticias/noticias/politica/483652-promulgada-emenda-constitucional-doorcamento-impositivo.html

${ }^{126}$ Bate-boca no Congresso derruba ministro e ofusca pacote de Dilma. Disponível em: https://brasil.elpais.com/brasil/2015/03/18/politica/1426717627_669791.html

${ }^{127}$ PMDB abraça bandeiras da oposição, como a redução de ministérios. Disponível em: https://brasil.elpais.com/brasil/2015/03/27/politica/1427416753_259569.html

${ }^{128}$ Manifestantes fazem maior protesto nacional contra o governo Dilma. Disponível em: http://g1.globo.com/politica/noticia/2016/03/manifestacoes-contra-governo-dilma-ocorrem-pelo-pais.html
} 
restritivas propostas pelo novo ministro da Fazenda, Joaquim Levy. Além disso, o avanço da Operação Lava-Jato desgastava o governo. Em sua delação premiada, o ex-diretor da Petrobras, Paulo Roberto Costa, afirmou que Dilma e Lula sabiam da existência de corrupção na companhia. Dilma Rousseff perdeu popularidade em um ritmo dramático, como demonstra a figura 14. A avaliação positiva do governo caiu de $42 \%$ em dezembro para $13 \%$ em março de 2015; já a avalição negativa subiu de $24 \%$ para $62 \%$ nesse período.

Figura 14. Avaliação de Governo. Governo Dilma.

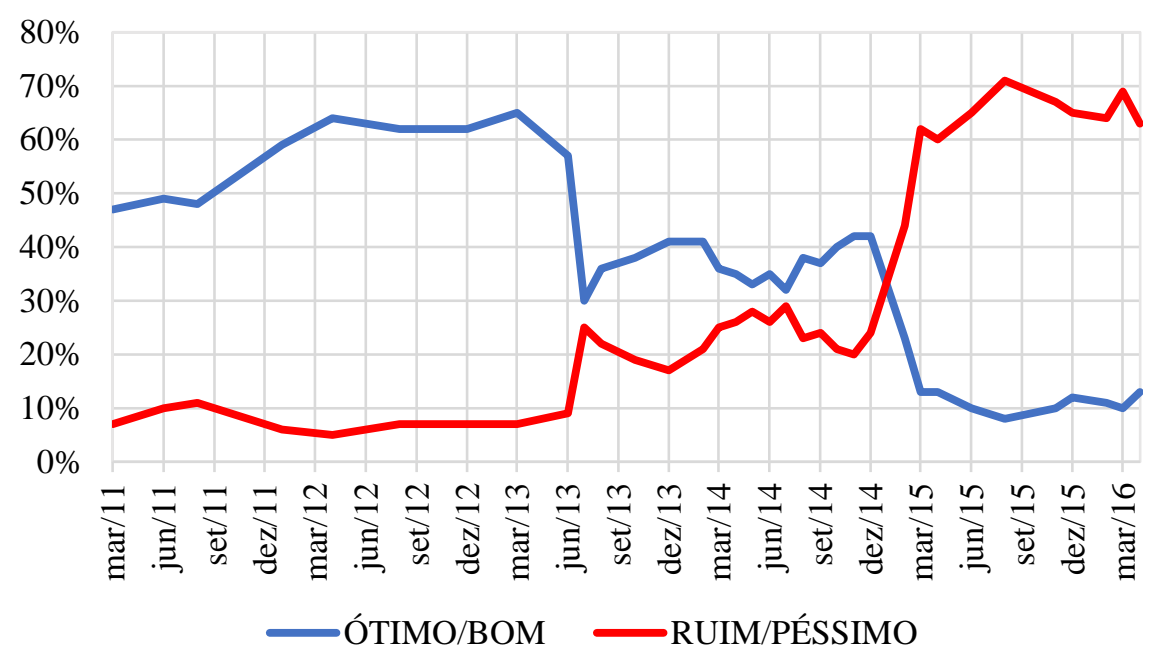

Fonte: Instituto Datafolha.

Além da insatisfação dos partidos da coalizão com o espaço que possuíam no governo, a postura da presidente em relação à Operação Lava-Jato contribuiu para o desgaste com os aliados. Na lista de políticos investigados pela operação constavam os nomes do presidente da Câmara e do presidente do Senado. Renan Calheiros acusou o Palácio do Planalto em aliança com o procurador-geral da República de tentar responsabilizar o Congresso Nacional pelos atos de corrupção praticados na Petrobras ${ }^{129}$.

Outra questão delicada em relação ao novo governo de Dilma Rousseff foi a pauta econômica. Na campanha de 2014, a presidente criticou os adversários que propuseram ajuste fiscal. Após a eleição, ela demitiu seu antigo ministro da Fazenda e o substituiu por um economista de linha ortodoxa, que apresentou ao país uma agenda com objetivo de combater o desequilíbrio fiscal. A relação entre Dilma Rousseff e Joaquim Levy nunca foi próxima. Além

${ }^{129}$ Dilma queria muitos na lista de Janot, desde que tivesse Aécio, diz Renan. Disponível em: https://fernandorodrigues.blogosfera.uol.com.br/2015/03/07/dilma-queria-muitos-na-lista-de-janot-desde-quetivesse-aecio-diz-renan/ 
disso, o ajuste fiscal jamais foi abraçado pelo PT, sendo essa uma das razões pelas quais o governo enfrentou dificuldades na aprovação das medidas no Congresso ${ }^{130}$.

Nesse período, o apoio ao afastamento da presidente já era majoritário entre a população ${ }^{131}$. Quase dois terços dos eleitores, segundo o Datafolha, apoiavam o impeachment de Dilma Rousseff.

\subsection{MICHEL TEMER ASSUME A ARTICULAÇÃO POLÍTICA}

Em meio à crescente impopularidade e às dificuldades no relacionamento com o Congresso Nacional, Dilma Rousseff se viu forçada a realizar reforma ministerial no início de abril, apenas três meses depois de sua posse. Pepe Vargas foi demitido e a pasta de Relações Institucionais foi extinta ${ }^{132}$. A articulação política ficaria, a partir de então, sob a responsabilidade do vice-presidente da República, Michel Temer. O gesto foi visto como tentativa do Palácio do Planalto de pacificar o PMDB e a base aliada, de modo a permitir a aprovação das medidas de ajuste fiscal pelo Congresso ${ }^{133}$. Além disso, houve substituição no ministério do Turismo: saiu Vinícius Lages e entrou Henrique Eduardo Alves, ex-presidente da Câmara e aliado de Temer e Eduardo Cunha ${ }^{134}$. A demissão de Lages, contudo, irritou Renan Calheiros, que nomeou o afilhado político como seu chefe de gabinete no Senado ${ }^{135}$.

Se a nomeação de Alves visava melhorar a relação com Eduardo Cunha, o governo não foi bem-sucedido a princípio. No início de maio, a Câmara aprovou, em segundo turno, a PEC da Bengala, que elevou a idade da aposentadoria compulsória dos ministros do STF para 75 anos. Com isso, Dilma Rousseff perderia a oportunidade de indicar 5 ministros para o tribunal. A derrota do governo foi expressiva: foram 333 votos favoráveis ao projeto e somente 144 contra. Somente PT e PCdoB encaminharam voto contrário, ao passo que PMDB, PP, PR e

\footnotetext{
${ }^{130}$ O duelo Levy-Rousseff. Disponível em: https://brasil.elpais.com/brasil/2015/03/30/opinion/1427741267_915296.html

${ }^{131}$ Maioria apoia abertura de processo de impeachment, mostra Datafolha. Disponível em: https://www1.folha.uol.com.br/poder/2015/04/1615424-maioria-quer-impeachment-de-dilma-e-nao-conhecevice.shtml

${ }^{132}$ Demitido da articulação, Pepe Vargas deve assumir Direitos Humanos. Disponível em: http://www1.folha.uol.com.br/poder/2015/04/1613624-demitido-da-articulacao-pepe-vargas-deve-assumirdireitos-humanos.shtml

$\frac{133}{13}$ Contra crise, Dilma entrega a articulação política a vice, do PMDB. Disponível em: https://brasil.elpais.com/brasil/2015/04/08/politica/1428452392_198425.html

${ }^{134}$ Dilma decide nomear Henrique Alves para o Turismo. Disponível em: http://g1.globo.com/politica/blog/blog-do-camarotti/post/dilma-decide-nomear-henrique-alves-para-oturismo.html

${ }^{135}$ Em atrito com o Planalto, Renan nomeia ex-ministro do Turismo como chefe de gabinete. Disponível em: http://politica.estadao.com.br/noticias/geral,em-atrito-com-o-planalto-renan-nomeia-ex-ministro-do-turismocomo-chefe-de-gabinete, 1671064
} 
PROS encaminharam voto favorável. PSD, PRB e PDT liberaram suas bancadas - embora o PSD tenha votado majoritariamente a favor do projeto. $\mathrm{O}$ resultado mostrou, mais uma vez, o isolamento do PT e do governo na Casa ${ }^{136}$.

O mês de maio foi marcado pela apreciação das duas medidas provisórias do ajuste fiscal propostas pela equipe econômica ao Congresso Nacional. A MP 665, que tornou mais rígidas as regras para o abono salarial, o seguro-desemprego e o seguro-defeso, foi aprovada pela Câmara com placar apertado: 252 votos favoráveis e 227 contrários ${ }^{137}$. No Senado, foram 39 votos favoráveis e 32 contrários $^{138}$. Já a MP 664, que alterou as regras da pensão por morte e do auxílio-doença foi aprovada com resultado mais folgado. Na Câmara, foram 277 votos favoráveis e 178 contrários $^{139}$. Contudo, o governo sofreu derrota importante durante a votação desta medida provisória: foi aprovada emenda pondo fim ao fator previdenciário - que desestimulava aposentadorias precoces ${ }^{140}$. Na votação desta emenda, foram 232 votos favoráveis e 210 contrários. O Senado aprovou a MP 664 com 50 votos favoráveis e 18 contrários, mas acatou a alteração da Câmara e derrubou o fator previdenciário ${ }^{141}$. Durante a votação das medidas de ajuste fiscal, houve defecções importantes na base governista, até mesmo no PT - que contribuiu decisivamente para o fim do fator previdenciário, por exemplo.

O governo ainda sofreria nova derrota no primeiro semestre de 2015 com a aprovação da redução da maioridade penal na Câmara dos Deputados, mediante articulação de Eduardo Cunha. O PT e o governo se posicionaram de modo contrário, mas, ainda assim, o projeto foi aprovado com apoio de 323 deputados $^{142}$.

Em julho, após acusações contra ele se tornarem públicas, o presidente da Câmara anunciou rompimento com Dilma Rousseff e acusou o governo de instrumentalizar as investigações da Operação Lava-Jato para prejudicá-lo. Nos bastidores, já se discutia a

\footnotetext{
${ }^{136}$ Câmara passa regra que impede Dilma de indicar 5 nomes ao STF. Disponível em: https://brasil.elpais.com/brasil/2015/05/06/politica/1430874775 545044.html

${ }^{137}$ Governo Dilma vence o primeiro 'round' do ajuste fiscal na Câmara. Disponível em: https://brasil.elpais.com/brasil/2015/05/06/politica/1430867818_281084.html

${ }^{138}$ Senado aprova MP 665 que altera regras do seguro-desemprego e abono salarial. Disponível em: https://oglobo.globo.com/brasil/senado-aprova-mp-665-que-altera-regras-do-seguro-desemprego-abono-salarial16267140

${ }^{139}$ Governo aprova segunda medida do ajuste fiscal e leva 'bote' da oposição. Disponível em: https://brasil.elpais.com/brasil/2015/05/14/politica/1431567290_572799.html

140 Câmara aprova emenda que cria alternativa ao fator previdenciário. Disponível em: http://www2.camara.leg.br/camaranoticias/noticias/trabalho-e-previdencia/487925-camara-aprova-emenda-quecria-alternativa-ao-fator-previdenciario.html

${ }^{141}$ Senado aprova MP 664 e derruba fator previdenciário. Disponível em:

https://www12.senado.leg.br/institucional/presidencia/noticia/renan-calheiros/senado-aprova-mp-664-e-derrubafator-previdenciario

${ }^{142}$ Cunha consegue nova virada e Câmara aprova redução da maioridade penal. Disponível em: http://www.bbc.com/portuguese/noticias/2015/07/150702_reducao_maioridade_aprovada_ms_tp
} 
possibilidade de Eduardo Cunha determinar abertura de processo de impeachment contra Dilma Rousseff ${ }^{143}$.

\subsection{O MÊS DE AGOSTO: PAUTA-BOMBA E O AFASTAMENTO DE TEMER}

No mês de agosto, as pressões contra o governo atingiriam novo patamar. A avalição negativa do governo atingiu $71 \%$, enquanto a avalição positiva caiu a $8 \%$. Ocorreram também novas manifestações expressivas contra o governo nas ruas em todo o país. No aspecto político, o mês de agosto marcaria o afastamento entre Dilma Rousseff e Michel Temer. No início do mês, após se reunir com os líderes da base aliada, o vice-presidente reconheceu o agravamento da crise política e disse que o país precisaria de alguém com capacidade de reunificar a todos ${ }^{144}$. A declaração não foi bem vista pelo círculo mais próximo da presidente. No final do mês, Temer entregou o cargo de articulador político do governo, alegando que havia concluído a votação da primeira etapa do ajuste fiscal (a aprovação das MPs 664 e 665) proposto pela equipe econômica ${ }^{145}$. Ainda assim, ficou evidente no episódio o distanciamento entre Dilma e Temer.

No Congresso, o início do segundo semestre foi marcado pelo avanço das chamadas pautas-bomba $^{146}$ - projetos de lei de reajustes salariais expressivos para vários segmentos do funcionalismo público, que comprometeriam o ajuste fiscal desenhado pela equipe econômica. A aprovação, em primeiro turno, da PEC 443 - que vinculava os salários das carreiras da Advocacia-Geral da União e de delegados aos vencimentos dos ministros do STF - pela Câmara no início de agosto foi um exemplo significativo. Na votação do texto principal, 445 deputados votaram favoravelmente ao projeto e somente 16 votaram contra. Todas as bancadas encaminharam voto a favor do projeto, contrariando a orientação da liderança do governo e os apelos da equipe econômica. O próprio PT encaminhou o voto favorável ao projeto. Os demais partidos da coalizão criticaram a posição do partido da presidente pelo pouco compromisso em

\footnotetext{
${ }^{143}$ Eduardo Cunha anuncia rompimento com o governo e diz que é 'oposição' . Disponível em: http://g1.globo.com/politica/noticia/2015/07/eduardo-cunha-anuncia-rompimento-politico-com-o-governodilma.html

${ }^{144}$ Temer diz que país precisa de alguém capaz de 'reunificar a todos' na crise. Disponível em: http://www1.folha.uol.com.br/poder/2015/08/1664881-temer-faz-apelo-publico-por-unidade-e-diz-que-crisepode-se-agravar.shtml

${ }^{145}$ Pressionado, Temer deixa a articulação política do governo. Disponível em: https://veja.abril.com.br/politica/pressionado-temer-deixa-a-articulacao-politica-do-governo/

${ }^{146}$ Saiba o que são as 'pautas-bomba' nas mãos do Congresso contra o governo. Disponível em: http://www1.folha.uol.com.br/mercado/2015/08/1664711-saiba-o-que-sao-as-pautas-bomba-nas-maos-docongresso-contra-o-governo.shtml
} 
relação à questão fiscal. Eduardo Cunha afirmou que a base do governo estava deteriorada e que ele nada poderia fazer para impedir o avanço de projetos semelhantes ${ }^{147}$.

Conforme pode ser observado na figura 3 do capítulo 3, em 2015, o governo perdeu apoio entre todas as bancadas da coalizão de governo na Câmara dos Deputados, até mesmo no partido da presidente da República. O quadro de deterioração fica patente.

Outro sinal de preocupação para o governo veio das manifestações favoráveis à presidente convocadas por movimentos de esquerda ${ }^{148}$. Embora a pauta das reivindicações contivesse críticas a Eduardo Cunha e a uma possível abertura de processo de impeachment contra Dilma Rousseff, também não faltaram críticas a Joaquim Levy e ao ajuste fiscal. Os segmentos populares que apoiavam o governo não esconderam as dificuldades em assimilar uma pauta diferente da apresentada pela presidente nas eleições. O próprio PT demonstrou o seu desconforto com o ajuste fiscal, por exemplo, na votação que derrubou o fator previdenciário e em relação ao reajuste do funcionalismo.

No que se refere ao PMDB, se a relação entre Dilma Rousseff e Eduardo Cunha e Michel Temer se deteriorava, o mesmo não se pode dizer acerca da relação com o presidente do Senado. Renan Calheiros avaliou que poderia ser um interlocutor privilegiado - ou o único, dito em outras palavras - do governo em um momento de grave crise e se reaproximou do Palácio do Planalto $^{149}$. Ele foi, por exemplo, fundamental para que o governo conseguisse aprovar a recondução de Rodrigo Janot à Procuradoria-Geral da República ${ }^{150}$.

Em setembro, Dilma Rousseff e a equipe econômica anunciaram novas medidas do ajuste fiscal, dentre elas, a recriação da CPMF, o congelamento dos reajustes de servidores e corte em programas sociais, como o Minha Casa Minha Vida. Embora necessárias, as medidas precisavam de apoio do Congresso Nacional para serem implementadas. Conforme pode ser visto nas votações anteriores, as perspectivas de aprovação dessas novas medidas não eram altas. A recriação da CPMF, sobretudo, foi alvo de críticas da base aliada e da oposição. Em uma sinalização à opinião pública, a presidente acenou com corte no número de ministérios ${ }^{151}$.

\footnotetext{
${ }^{147}$ Após avanço de 'pauta-bomba', Cunha fala em base 'deteriorada'. Disponível em: http://g1.globo.com/politica/noticia/2015/08/apos-avanco-de-pauta-bomba-cunha-fala-em-base-deteriorada.html ${ }^{148}$ Esquerda vai às ruas em manifestação contra impeachment, Cunha e Levy. Disponível em: https://brasil.elpais.com/brasil/2015/08/21/politica/1440124250_602504.html

${ }^{149}$ Renan volta do recesso parlamentar governista. Disponível em: http://congressoemfoco.uol.com.br/noticias/renan-volta-do-recesso-com-postura-governista/

${ }_{150}$ Acordo Dilma-Renan envolve também a aprovação do nome de Janot no Senado. Disponível em: http://g1.globo.com/politica/blog/matheus-leitao/post/acordo-dilma-renan-envolve-tambem-aprovacao-do-nomede-janot-no-senado.html

${ }^{151}$ Mais tributos e mais cortes: a conta da austeridade que o brasileiro vai pagar. Disponível em: https://brasil.elpais.com/brasil/2015/09/15/politica/1442271444_522241.html
} 


\subsection{A REFORMA MINISTERIAL DE OUTUBRO DE 2015}

Em outubro, Dilma Rousseff anunciou nova reforma ministerial. Houve redução no número de ministérios, de 39 para $31^{152}$. Jaques Wagner, próximo ao ex-presidente Lula, assumiu a Casa Civil, em substituição a Aloizio Mercadante - que retornou ao ministério da Educação $^{153}$. A condução de Mercadante era bastante criticada por partidos aliados do governo e pelo próprio PT. Ricardo Berzoini assumiu a Secretaria de Governo, de modo a trabalhar ao lado de Wagner e reconstruir a relação entre o Executivo e a coalizão.

$\mathrm{O}$ espaço do PMDB no ministério foi bastante ampliado, como mostra a figura 15 . $\mathrm{O}$ partido foi contemplado com os ministérios da Saúde e da Ciência e Tecnologia. As indicações foram negociadas com o líder do PMDB na Câmara, Leonardo Picciani, que se distanciou de Eduardo Cunha e se aproximou do Palácio do Planalto. Foram indicados os deputados Marcelo Castro (Saúde) e Celso Pansera (Ciência e Tecnologia) ${ }^{154}$. O PMDB ainda manteve Henrique Eduardo Alves (Turismo), Eliseu Padilha (Aviação Civil), Eduardo Braga (Minas e Energia) e Kátia Abreu (Agricultura), além de Helder Barbalho - que deixou o ministério da Pesca, extinto, e assumiu a pasta de Portos. Embora a negociação com o PMDB tenha ocorrido à margem do comando nacional da legenda - Michel Temer, por exemplo, não participou do acordo -, ao menos, o governo consolidou o apoio de uma parcela do partido. Além disso, o PDT assumiu a pasta de Comunicações, com o líder do partido na Câmara. O PT teve seu espaço reduzido, sobretudo por conta da perda do ministério da Saúde (embora o partido tenha recuperado a pasta da Educação, anteriormente ocupada por Cid Gomes e Renato Janine), mas também pela fusão entre as pastas de Direitos Humanos, Políticas para as Mulheres e Igualdade Racial.

\footnotetext{
${ }^{152}$ Dilma anuncia reforma com redução de 39 para 31 ministérios. Disponível em: http://g1.globo.com/politica/noticia/2015/10/dilma-anuncia-reducao-de-39-para-31-pastas-na-reformaministerial.html

${ }^{153}$ Dilma troca Mercadante por Jaques Wagner na Casa Civil. Disponível em: http://www1.folha.uol.com.br/fsp/poder/234992-dilma-troca-mercadante-por-jaques-wagner-na-casa-civil.shtml ${ }^{154}$ Dilma a Picciani: Castro e Pansera ocuparão Saúde e Ciência. Disponível em: https://exame.abril.com.br/brasil/dilma-a-picciani-castro-e-pansera-ocuparao-saude-e-ciencia/
} 
Figura 15. Investimentos dos Ministérios - Por Partido. Governo Dilma.

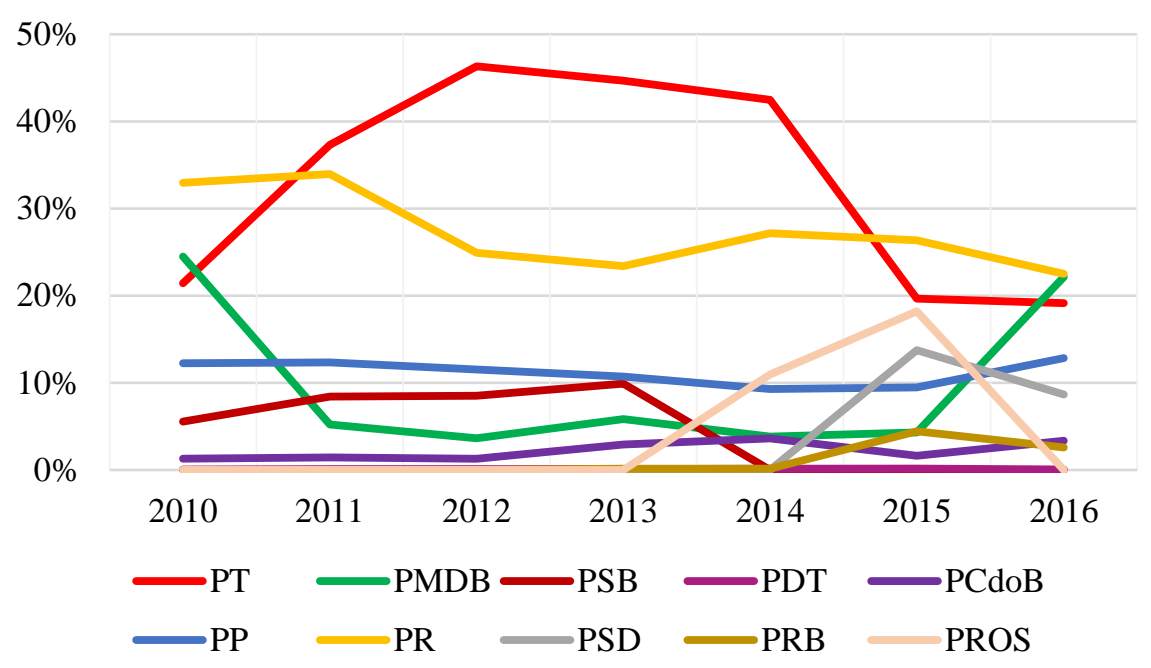

Fonte: Banco de dados do SIAFI. Valor empenhado, em porcentagem.

Em novembro, em um primeiro teste da nova articulação política, o governo foi bemsucedido na manutenção do veto de Dilma Rousseff ao reajuste dos servidores do Poder Judiciário. Contudo, o placar foi apertado: 251 deputados votaram favoravelmente à derrubada do veto da presidente - eram necessários 257 votos. Somente 132 deputados foram favoráveis à manutenção do veto, como pretendia o governo ${ }^{155}$.

Lula elogiou a nova equipe de Dilma Rousseff, mas avaliou que a recomposição do ministério deveria ser sido feita antes mesmo da posse de seu segundo mandato, de modo a reequilibrar as forças dos partidos da coalizão ${ }^{156}$. De fato, conforme pode ser visto na figura 15 , a reforma ministerial de outubro de 2015 significou alteração bastante significativa no espaço dos partidos da coalizão no ministério. O PMDB ganhou força, ao passo que o espaço do PT se reduziu. Contudo, como se verá ao longo do capítulo, a recomposição veio tarde demais. O avanço da Operação Lava-Jato jogaria por terra qualquer tentativa do governo de se reerguer.

\subsection{A PRISÃO DE DELCÍDIO E A ABERTURA DO IMPEACHMENT}

Em 25 de novembro, o STF autorizou a prisão do líder do governo no Senado, Delcídio do Amaral (PT). A decisão foi de Teori Zavascki, mas referendada pelos demais ministros da

\footnotetext{
${ }^{155}$ Dilma distribui ministérios e garante vitória parcial em sessão do Congresso. Disponível em: https://brasil.elpais.com/brasil/2015/09/23/politica/1442977828 193938.html

156 'Dilma faz agora o que deveria ter feito em novembro', diz Lula sobre reforma ministerial. Disponível em: $\quad$ http://politica.estadao.com.br/noticias/geral,dilma-faz-agora-o-que-deveria-ter-feito-em-novembro--diz$\underline{\text { lula, } 1771951}$
} 
Corte $^{157}$. Em gravações, o senador ofereceu dinheiro ao filho do ex-diretor da Petrobras, Nestor Cerveró, para que o pai não fechasse acordo de delação premiada. A Constituição somente prevê a prisão de parlamentares em flagrante de crime inafiançável; a prisão precisa ainda ser autorizada pela respectiva Casa Legislativa. No mesmo dia, o Senado autorizou a prisão por 59 votos favoráveis e 13 contrários em votação aberta ${ }^{158}$. O presidente da Casa, Renan Calheiros, defendeu a realização de votação secreta, mas a maioria do plenário decidiu de forma diferente. Delcídio do Amaral ficaria preso por tempo indeterminado. Jamais um senador da República havia sido preso durante o exercício do mandato, desde a redemocratização.

O episódio envolvendo a prisão do senador mostrou a fragilidade do governo diante do avanço da Operação Lava-Jato. Dilma Rousseff, por diversas vezes, defendeu as investigações e imaginou que sobreviveria à operação. Sempre que pode, o Palácio do Planalto tratou o escândalo da Petrobras como fatos ocorridos no governo anterior com a participação de partidos aliados. A prisão do líder do governo demonstrou que o Poder Executivo não tinha controle algum sobre o rumo das investigações, não sendo, portanto, capaz de oferecer proteção a quem quer que fosse. A partir de então, os desdobramentos desse caso levariam à destituição da presidente da República, em meio à desconfiança do Congresso Nacional em relação à sua capacidade de reação ${ }^{159}$.

Em 2 de dezembro, o PT tomou a decisão que desencadearia a abertura do processo de impeachment contra Dilma Rousseff. Em razão das investigações da Operação Lava-Jato, foi aberto processo no Conselho de Ética da Câmara dos Deputados contra o presidente da Casa. Eduardo Cunha havia negociado com líderes do PT o voto dos deputados do partido para o arquivamento do processo contra ele; em contrapartida, ele arquivaria os pedidos de abertura de impeachment contra a presidente. Contudo, na presente data, o Partido dos Trabalhadores decidiu votar pela continuidade do processo contra o presidente da Câmara ${ }^{160}$.

\footnotetext{
${ }^{157}$ Por unanimidade, STF confirma prisão de senador Delcídio. Disponível em: https://noticias.uol.com.br/politica/ultimas-noticias/2015/11/25/em-sessao-extraordinaria-stf-confirma-prisao-desenador-delcidio.htm

${ }^{158}$ Em votação aberta, Senado dá aval à prisão de Delcídio decretada pelo STF. Disponível em: http://g1.globo.com/politica/noticia/2015/11/em-votacao-aberta-senado-da-aval-prisao-de-delcidio-decretadapelo-stf.html

${ }^{159}$ A mudança do discurso de Dilma sobre a Lava Jato em oito frases. Disponível em: https://www.nexojornal.com.br/expresso/2016/03/19/A-mudan\%C3\%A7a-do-discurso-de-Dilma-sobre-a-LavaJato-em-oito-frases

${ }^{160}$ PT decide votar contra Cunha, que pode deflagrar impeachment de Dilma. Disponível em: http://www1.folha.uol.com.br/poder/2015/12/1713918-bancada-petista-decide-votar-contra-cunha-no-conselhode-etica-da-camara.shtml
} 
A reação de Eduardo Cunha veio poucas horas depois. Ao final da tarde do próprio 2 de dezembro, ele anunciou a abertura de processo de impeachment contra Dilma Rousseff ${ }^{161}$. O requerimento aceito havia sido formulado pelos juristas Hélio Bicudo e Miguel Reale Júnior e estava baseado na ocorrência das chamadas "pedaladas fiscais" - em outras palavras, o atraso no repasse de recursos a bancos públicos a fim de cumprir as metas orçamentárias estabelecidas em lei - e na edição de decretos de crédito extraordinário sem aprovação do Congresso Nacional em 2015, em descumprimento à Lei de Responsabilidade Fiscal.

Poucos dias depois, em 7 de dezembro, o vice-presidente da República explicitaria o rompimento com Dilma Rousseff, em carta na qual expressava seu desconforto em relação ao governo. Michel Temer listou uma dezena de fatos a fim de demonstrar o desprestígio do PMDB no governo e concluiu não gozar de confiança por parte da presidente; afirmou ainda ter desempenhado papel de vice "figurativo"162. No mesmo dia, o ministro da Aviação Civil, Eliseu Padilha, braço-direito de Temer, entregou sua carta de demissão ${ }^{163}$.

No dia seguinte, em 8 de dezembro, a Câmara votou a indicação dos integrantes para a comissão que iria analisar o juízo de admissibilidade do processo de impeachment. A votação foi secreta e duas chapas foram lançadas, a do governo e a da oposição - com apoio de setores dissidentes da base aliada. Em votação secreta, a oposição saiu vencedora e elegeu seus integrantes para a comissão do impeachment. O placar foi de 272 a 199. Para aprovação do afastamento presidencial seriam necessários 342 votos. Ou seja, embora o placar de 199 votos mostrasse enfraquecimento do governo, ainda não havia número suficiente para a destituição de Dilma Rousseff. Contudo, a evolução dos fatos era extremamente negativa para a presidente. Logo após o resultado da eleição na Câmara, o PCdoB entrou com ação no STF pedindo que o processo de impeachment fosse suspenso até que o tribunal esclarecesse o rito a ser seguido pelo Poder Legislativo. A ação foi aceita pelo ministro Edson Fachin, do STF, e o processo foi suspenso. A decisão do STF sobre o rito determinou voto aberto para a eleição da comissão do impeachment e também invalidou candidaturas avulsas - assim, caberia aos líderes partidárias as indicações para a comissão. A decisão foi favorável ao governo e a eleição dos integrantes da comissão deveria ser refeita, com base nas regras estabelecidas pelo STF. Assim, o

\footnotetext{
${ }^{161}$ Eduardo Cunha autoriza abrir processo de impeachment de Dilma. Disponível em: http://g1.globo.com/politica/noticia/2015/12/eduardo-cunha-informa-que-autorizou-processo-de-impeachmentde-dilma.html

$\frac{162}{16 e i a}$ a íntegra da carta enviada pelo vice Michel Temer a Dilma. Disponível em: http://g1.globo.com/politica/noticia/2015/12/leia-integra-da-carta-enviada-pelo-vice-michel-temer-dilma.html ${ }_{163}$ Casa Civil confirma pedido de demissão de Eliseu Padilha. Disponível em: http://g1.globo.com/politica/noticia/2015/12/casa-civil-confirma-pedido-de-demissao-de-eliseu-padilha.html
} 
impeachment ficaria paralisado durante todo o recesso parlamentar e somente voltaria a tramitar em fevereiro de $2016^{164}$.

Em meados de dezembro, o ministro da Fazenda, Joaquim Levy, entregou seu pedido de demissão. No período em que esteve à frente da pasta, o governo não conseguiu aprovar boa parte do ajuste fiscal proposto pela equipe econômica no Congresso Nacional e ainda viu avançar projetos de reajuste de servidores, as chamadas "pautas-bomba". A situação fiscal brasileira permaneceu em trajetória negativa. Além disso, o país perdeu o grau de investimento e entrou em recessão. A saída de Levy era o sinal de que pouco poderia ser feito em relação à agenda econômica durante o governo de Dilma Rousseff, que não inspirava confiança no mercado financeiro tampouco no Congresso Nacional. Os meses seguintes seriam destinados à batalha do impeachment, o que, provavelmente, tenha precipitado a saída de Levy. O ministro do Planejamento, Nelson Barbosa, foi nomeado para pasta da Fazenda ${ }^{165}$.

O recesso do final do ano funcionou como uma trégua para o governo. Com a suspensão do processo e a definição do rito pelo STF, o governo federal aproveitou o mês de janeiro para reorganizar a base aliada para a batalha do impeachment. Em fevereiro, no retorno das atividades do Congresso, o governo trabalhou pela recondução de Leonardo Picciani para a liderança do PMDB da Câmara - e foi bem-sucedido ${ }^{166}$. Picciani, que se tornou aliado importante do governo, derrotou Hugo Motta, ligado a Eduardo Cunha, com uma diferença de 7 votos: 37 a 30. Desde que se distanciou do grupo de Michel Temer, o Palácio do Planalto havia se aproximado do PMDB fluminense ${ }^{167}$. Picciani articulou as indicações dos ministros da Saúde e da Ciência e Tecnologia, na reforma ministerial ocorrida em outubro.

Além disso, Dilma Rousseff nomeou o então ministro da Justiça, José Eduardo Cardozo, para a Advocacia-Geral da União, onde trataria de apresentar a defesa da presidente durante o processo de impeachment ${ }^{168}$. A postura de Cardozo em relação ao avanço da Operação LavaJato desagradava ao PT, sobretudo a Lula, que considerava a postura do ministro pouca combativa.

\footnotetext{
${ }^{164}$ Oposição vence votação para comissão e STF suspende impeachment. Disponível em: http://www.bbc.com/portuguese/noticias/2015/12/151208_comissao_impeachment_ab ${ }^{165}$ Levy deixa Fazenda após 11 meses no cargo e sucessivas derrotas. Disponível em: http://g1.globo.com/economia/noticia/2015/12/levy-deixa-fazenda-apos-11-meses-no-cargo-e-sucessivasderrotas.html

${ }^{166}$ Aliado do Planalto, Picciani é reeleito líder do PMDB na Câmara. Disponível em: http://g1.globo.com/politica/noticia/2016/02/aliado-do-planalto-picciani-e-reeleito-lider-do-pmdb-nacamara.html

167 Como o PMDB do Rio se tornou boia de salvação de Dilma. Disponível em: http://www.bbc.com/portuguese/noticias/2016/02/160216_rousseff_pmdb_ms

${ }^{168}$ Cardozo vai para a AGU e aliado de Wagner assume Ministério da Justiça. Disponível em: http://politica.estadao.com.br/noticias/geral,dilma-tenta-manter-cardozo-na-agu,10000018802
} 


\subsection{A CONDUÇÃO COERCITIVA DE LULA E O COMEÇO DO FIM}

Em fevereiro de 2016, a presidente Dilma Rousseff assistiu à prisão preventiva do publicitário que coordenou sua campanha, João Santana ${ }^{169}$. No dia 4 de março, o ex-presidente Lula foi alvo de condução coercitiva, determinada pelo então juiz Sérgio Moro ${ }^{170}$. Assim como no caso da prisão do senador Delcídio do Amaral, a decisão veio em péssima hora para o governo. Em um momento em que tentava reorganizar a base aliada para sobreviver ao pedido de afastamento no Congresso Nacional, a condução coercitiva de Lula representou novo revés para Dilma Rousseff. Em 10 de março, o Ministério Público de São Paulo pediu a prisão preventiva do ex-presidente. Embora tenha sido negada, os dias seguintes seriam marcados pela tensão dentro do governo federal, que temia novas ações contra seus integrantes em meio ao avanço da Operação Lava-Jato. No domingo, 13 de março, ocorreriam as maiores manifestações contra o governo em meio a reivindicações favoráveis ao impeachment e à prisão do ex-presidente Lula. Os protestos tomaram as ruas das cidades em todo o país ${ }^{171}$.

Na quarta-feira seguinte, 16 de março, Dilma Rousseff anunciou Luiz Inácio Lula da Silva como novo ministro-chefe da Casa Civil. Jaques Wagner foi deslocado para a Chefia do Gabinete Pessoal da presidência da República ${ }^{172}$. A nomeação de Lula cumpria dois objetivos. Por um lado, garantia-lhe prerrogativa de foro no STF - afastando-o do juízo de Sérgio Moro e evitando possível pedido de prisão preventiva. Por outro lado, Lula gozava de prestígio junto a importantes setores do Congresso Nacional e poderia articular a reação do governo para garantir o arquivamento do processo de impeachment. Se bem-sucedido na função, Lula faria a recomposição da coalizão de governo e se tornaria fiador da permanência de Dilma Rousseff no cargo.

A estratégia poderia ser bem-sucedida, não fosse a reação imediata do juiz Sérgio Moro de tornar públicas as investigações contra Lula e retirar o sigilo de interceptações telefônicas do ex-presidente, incluindo diálogo ocorrido com Dilma Rousseff, em que são acertados os

\footnotetext{
${ }^{169}$ E a Lava Jato pegou João Santana. Disponível em: https://epoca.globo.com/tempo/noticia/2016/02/e-lava-jato-pegou-joao-santana.html ${ }^{170}$ Justiça autoriza condução coercitiva de Lula e Okamotto para prestar depoimento. Disponível em: http://politica.estadao.com.br/blogs/fausto-macedo/pf-esta-nos-enderecos-de-lula-e-fabio-luis-em-nova-fase-dalava-jato/

${ }^{171}$ Maior manifestação da história do País aumenta pressão por saída de Dilma. Disponível em: https://politica.estadao.com.br/noticias/geral,manifestacoes-em-todos-os-estados-superam-as-de-marco-do-anopassado, 10000021047

${ }^{172}$ Planalto anuncia Lula como novo ministro da Casa Civil. Disponível em:

http://g1.globo.com/politica/noticia/2016/03/planalto-anuncia-lula-como-novo-ministro-da-casa-civil.html
} 
termos de sua nomeação para o ministério ${ }^{173}$. Dentre todas as gravações divulgadas, o trecho que causou maior repercussão foi o transcrito abaixo:

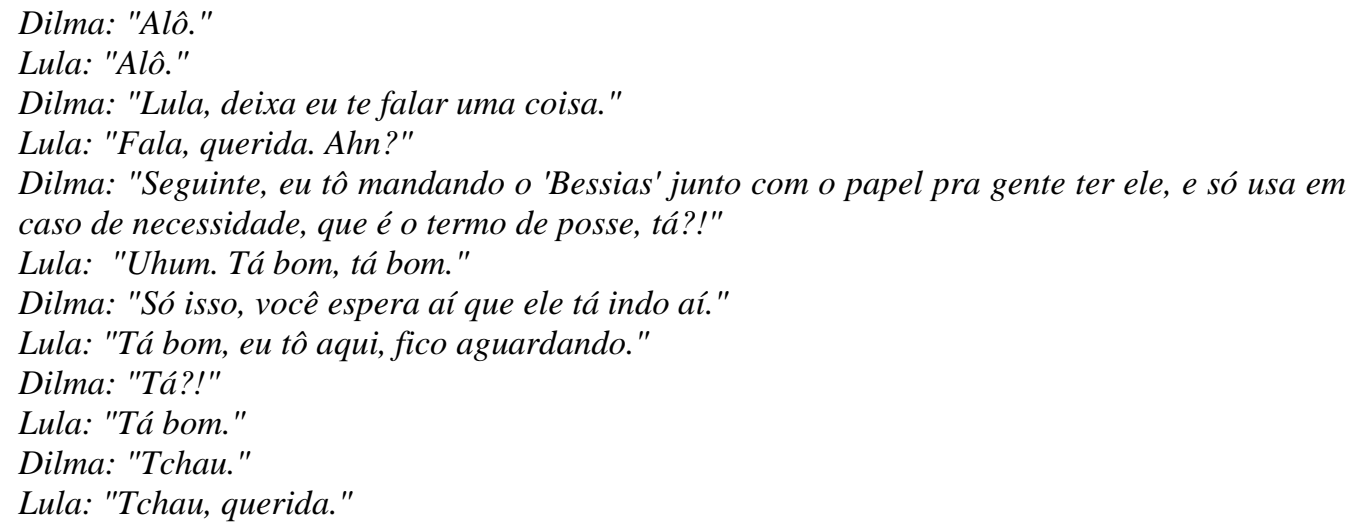

A decisão de Moro foi bastante questionada. Posteriormente, o STF anulou as escutas telefônicas entre Lula e Dilma Rousseff e apontou que Moro usurpou a competência do tribunal ao autorizar os grampos que expuseram a presidente. Além disso, o trecho do diálogo entre Lula e Dilma que mais causou repercussão ocorreu depois do prazo autorizado pela justiça. O juiz alegou interesse público para a divulgação dos áudios, mas é difícil desprezar o caráter político da decisão.

De qualquer forma, o prejuízo político para o governo era inquestionável. Na própria quarta-feira, manifestantes em várias cidades protestaram contra a nomeação de Lula para o ministério. As gravações divulgadas por Moro objetivavam mostrar que o ex-presidente pretendia, com a nomeação, obter foro privilegiado junto ao STF, livrando-se da alçada de justiça de Curitiba.

Mesmo diante da repercussão negativa, Lula tomou posse na quinta-feira, 17 de março, pela manhã. $\mathrm{O}$ evento, contudo, foi esvaziado e não contou com a presença da maior parte dos partidos aliados. Na noite anterior, o PRB havia definido o rompimento com o governo, sendo o primeiro partido a abandonar formalmente a coalizão governista ${ }^{174}$. O PMDB também não participou da posse de Lula. O partido havia decidido em reunião no sábado anterior, 12 de março, que não aceitaria novos cargos e que faria novo encontro no prazo de 30 dias para oficializar a posição em relação ao governo. Contudo, além da nomeação de Lula, Dilma indicou o deputado Mauro Lopes (PMDB-MG) para a pasta da Aviação Civil, o que foi visto

\footnotetext{
${ }^{173}$ Moro derruba sigilo e divulga grampo de ligação entre Lula e Dilma. Disponível em: http://g1.globo.com/pr/parana/noticia/2016/03/pf-libera-documento-que-mostra-ligacao-entre-lula-e-dilma.html ${ }_{174}$ PRB rompe com Dilma e é primeiro partido a deixar base do governo. Disponível em: https://noticias.r7.com/brasil/prb-rompe-com-dilma-e-e-primeiro-partido-a-deixar-base-do-governo-17032016
} 
como uma afronta pelo PMDB ${ }^{175}$. O gesto de Dilma teve potencial de unir o partido contra ela. O PMDB decidiu, assim, antecipar o rompimento oficial com o governo para 29 de março.

$\mathrm{Na}$ própria quinta-feira, a Câmara aprovou a criação da comissão do impeachment, mediante amplo acordo em relação aos seus integrantes e segundo as regras estabelecidas pelo STF. Para a presidência da comissão foi designado o líder do PSD, Rogério Rosso. O líder do PTB, Jovair Arantes, foi escolhido relator. Embora nenhum dos dois parlamentares estivesse alinhado à oposição, tampouco representavam qualquer garantia de tranquilidade ao governo ${ }^{176}$.

Em relação a Lula, várias ações populares pediram a suspensão da posse do expresidente. Na sexta-feira, 18 de março, o ministro Gilmar Mendes concedeu liminar a pedido de partidos de oposição e suspendeu a posse de Lula para o ministério. O ministro do STF enxergou desvio de finalidade na nomeação e devolveu o caso para a vara de justiça de Sérgio Moro, em Curitiba ${ }^{177}$. A decisão de Gilmar Mendes foi o tiro de misericórdia no governo Dilma Rousseff. Sem autoridade sequer para nomear um ministro, a destituição da presidente seria questão de tempo - pouco tempo, como ver-se-á nos próximos parágrafos.

Com Lula fora do ministério e a comissão do impeachment em funcionamento na Câmara, assistiu-se à implosão da coalizão. Após o afastamento do PRB, em 29 de março foi a vez do PMDB anunciar formalmente o rompimento com o governo de Dilma Rousseff ${ }^{178}$. Na véspera do encontro do partido, o ministro do Turismo, Henrique Eduardo Alves, próximo a Michel Temer, pediu demissão ${ }^{179}$. A decisão do PMDB ocorreu por aclamação. O ex-presidente Lula ainda tentou obter apoio de Renan Calheiros e José Sarney para adiar o encontro do partido, mas não obteve sucesso. O temor do governo era que a decisão do PMDB - o maior partido da coalizão - fosse seguida pelos demais partidos governistas. Na verdade, foi o que aconteceu nos dias seguintes.

\footnotetext{
${ }^{175}$ Depois de 'afronta', PMDB vai antecipar reunião para decidir rompimento com governo. Disponível em: http://politica.estadao.com.br/noticias/geral,depois-de-afronta--pmdb-vai-antecipar-reuniao-para-decidirrompimento-com-governo, 10000021794

${ }^{176}$ Base fez acordo para que PTB e PSD comandem comissão, diz Guimarães. Disponível em: http://g1.globo.com/politica/processo-de-impeachment-de-dilma/noticia/2016/03/base-fez-acordo-para-que-ptbe-psd-comandem-comissao-diz-guimaraes.html

${ }^{177}$ Gilmar Mendes suspende posse de Lula como ministro e devolve caso a Moro. Disponível em: https://veja.abril.com.br/brasil/gilmar-mendes-suspende-posse-de-lula-como-ministro-e-devolve-caso-a-moro/

${ }^{178}$ Por aclamação, PMDB oficializa rompimento com governo Dilma. Disponível em: http://g1.globo.com/politica/noticia/2016/03/por-aclamacao-pmdb-oficializa-rompimento-com-governodilma.html

${ }^{179}$ Henrique Alves pede demissão do Ministério do Turismo. Disponível em: http://g1.globo.com/jornal-nacional/noticia/2016/03/ministro-henrique-alves-pede-demissao-do-ministerio-doturismo.html
} 
Depois de perder o apoio do PMDB, o governo tentou negociar os cargos ocupados pelo partido com as demais siglas aliadas. O ministério da Saúde chegou a ser oferecido ao $\mathrm{PP}^{180}$ e aos pequenos partidos foram oferecidas vagas em autarquias e empresas estatais. Contudo, as negociações fracassaram.

Em 11 de abril, segunda-feira, a comissão da Câmara aprovou relatório favorável à abertura de processo de impeachment contra Dilma Rousseff. Foram 38 votos favoráveis e 27 contrários $^{181}$. A votação mostrou que, embora alguns líderes de partidos aliados ainda se mantivessem contrários ao impeachment, a maior parte dos parlamentares desses partidos já defendia o afastamento da presidente. No mesmo dia, vazou áudio em que o vice-presidente Michel Temer discursava como se o impeachment já tivesse sido aprovado pela Câmara dos Deputados ${ }^{182}$. Embora tenha sido divulgado por engano, segundo a assessoria de Temer, o vicepresidente detalhava no áudio seu compromisso com os programas sociais e com a retomada econômica, além de ressaltar seu apreço ao Poder Legislativo.

O presidente da Câmara, Eduardo Cunha (PMDB), marcou para o domingo seguinte, 17 de abril, a votação do plenário da Casa para decidir sobre aceitação do relatório favorável ao impeachment da presidente Dilma Rousseff. A semana seria marcada por intensas negociações. O ex-presidente Lula, mesmo sem cargo no governo, transferiu-se para Brasília para tentar salvar o mandato de sua sucessora. No Hotel Golden Tulip, Lula se dispôs a receber parlamentares de diversos partidos de modo a convencê-los a votar contra o afastamento da presidente $^{183}$.

No entanto, a semana foi marcada pelo desembarque dos partidos aliados. Na terçafeira, 12 de abril, o PRB fechou questão para que seus parlamentares votassem de modo favorável ao impeachment. A maior derrota do governo viria do encontro do PP - que, com a saída do PMDB, tornara-se o maior partido aliado -, realizado também na terça-feira. O partido decidiu romper com o governo e encaminhar voto favorável ao impeachment ${ }^{184}$. A decisão surpreendeu o governo e jogou por terra as esperanças de Dilma Rousseff sobreviver ao

\footnotetext{
${ }^{180}$ Governo oferece Ministério da Saúde para evitar desembarque do PP. Disponível em: http://www1.folha.uol.com.br/poder/2016/03/1755571-governo-oferece-ministerio-da-saude-para-evitardesembarque-do-pp.shtml

${ }^{181}$ Comissão da Câmara aprova processo de impeachment de Dilma. Disponível em: http://g1.globo.com/politica/processo-de-impeachment-de-dilma/noticia/2016/04/comissao-da-camara-aprovaprocesso-de-impeachment-de-dilma.html

${ }^{182}$ Em áudio, Temer fala como se Câmara já tivesse aprovado impeachment. Disponível em: http://g1.globo.com/politica/processo-de-impeachment-de-dilma/noticia/2016/04/e-preciso-um-governo-desalvacao-nacional-afirma-vice-michel-temer.html ${ }_{183}$ O negociador Lula que tenta salvar o Governo Dilma do impeachment. Disponível em: https://brasil.elpais.com/brasil/2016/04/09/politica/1460166122_568182.html

${ }^{184}$ PP e PRB anunciam apoio oficial a impeachment e enfraquecem base de Dilma. Disponível em: http://www.bbc.com/portuguese/noticias/2016/04/160412_prb_impeachment_rs
} 
processo. Na sexta-feira, 15 de abril, o PP fez nova reunião: decidiu fechar questão sobre o tema e ameaçou punir os parlamentares dissidentes ${ }^{185}$.

Em novos sinais de que o governo se aproximava do fim, o ministro das Cidades, Gilberto Kassab, presidente nacional do PSD, entregou o cargo na sexta-feira à noite. Ele alegou que não teria como permanecer no governo, uma vez que seu partido votaria majoritariamente pelo impeachment ${ }^{186}$.

No PR, apesar não ter havido rompimento oficial com governo, o presidente nacional da legenda, Alfredo Nascimento (AM) ${ }^{187}$, e o líder do partido na Câmara, Maurício Quintella (AL), votaram de modo favorável ao impeachment.

No PMDB, a resistência ficou restrita ao líder do partido na Câmara, Leonardo Picciani (RJ), e aos parlamentares mais próximos a ele. O próprio deputado Mauro Lopes, que havia assumido a pasta da Aviação Civil, deixou o ministério e gravou vídeo declarando o voto a favor da saída de Dilma Rousseff do cargo ${ }^{188}$.

O plenário da Câmara começou as discussões sobre o relatório do deputado Jovair Arantes (PTB), favorável ao prosseguimento do processo de impeachment, na sexta-feira, 15 de abril. A votação do relatório foi realizada no domingo, 17 de abril, conforme a previsão da presidência da Casa. A Câmara dos Deputados autorizou a instauração do processo de impeachment de Dilma Rousseff por 367 votos favoráveis e 137 contrários ${ }^{189}$. Eram necessários 342 votos para o prosseguimento do processo. No total, $72 \%$ dos deputados votaram contra Dilma Rousseff. A figura 16 mostra como votaram os partidos da antiga base de apoio ao governo em relação ao afastamento da presidente.

\footnotetext{
${ }^{185}$ PP fecha questão a favor do impeachment e punirá dissidentes. Disponível em: http://www.valor.com.br/politica/4525967/pp-fecha-questao-favor-do-impeachment-e-punira-dissidentes ${ }^{186}$ Gilberto Kassab pede demissão do Ministério das Cidades, diz Planalto. Disponível em: http://g1.globo.com/politica/noticia/2016/04/gilberto-kassab-pede-demissao-do-ministerio-das-cidades.html ${ }^{187}$ Alfredo Nascimento renuncia à presidência do PR e vota por impeachment. Disponível em: https://www.valor.com.br/politica/4527515/alfredo-nascimento-renuncia-presidencia-do-pr-e-vota-porimpeachment

${ }^{188}$ Ministro de Dilma até dias atrás, Mauro Lopes votará a favor do impeachment. Disponível em: https://oglobo.globo.com/brasil/ministro-de-dilma-ate-dias-atras-mauro-lopes-votara-favor-do-impeachment19109963

${ }^{189}$ Câmara autoriza instauração de processo de impeachment de Dilma com 367 votos a favor e 137 contra. Disponível em: http://www2.camara.leg.br/camaranoticias/noticias/politica/507325-camara-autoriza-instauracaode-processo-de-impeachment-de-dilma-com-367-votos-a-favor-e-137-contra.html
} 
Figura 16. Votos favoráveis à abertura do impeachment - Partidos da Coalizão. Câmara dos Deputados.

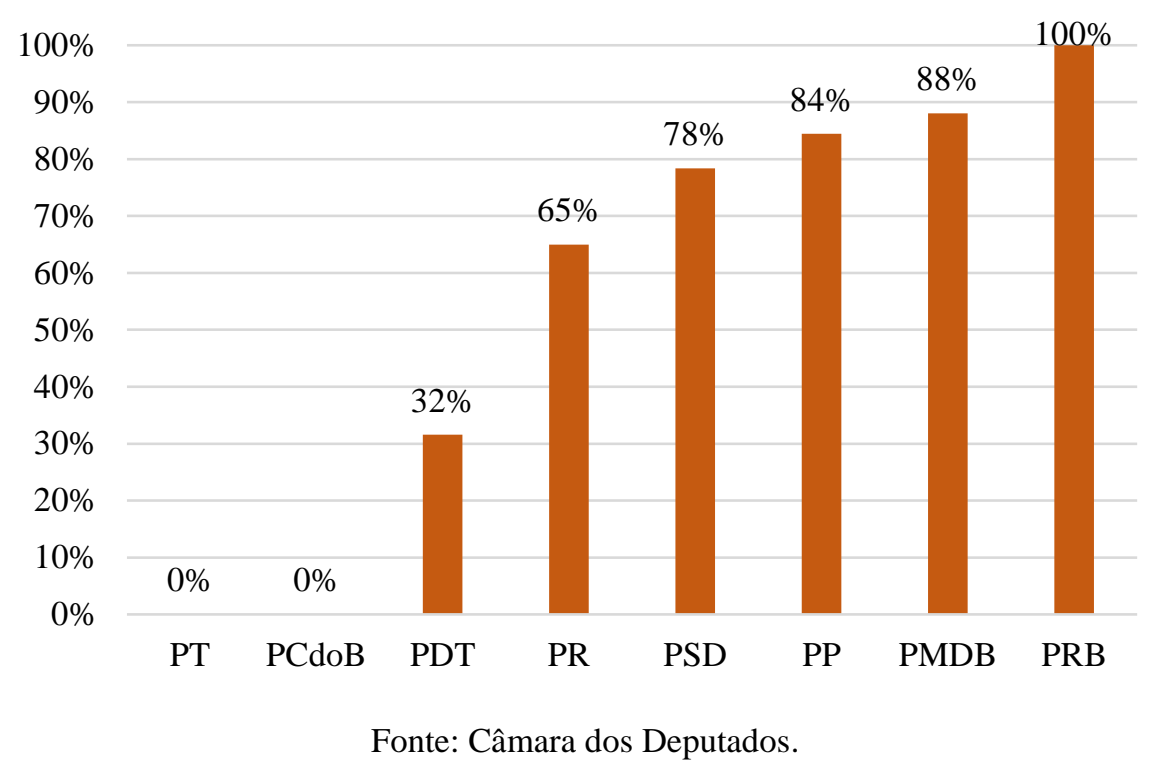

Como pode ser visto na figura acima, o apoio a Dilma Rousseff ficou restrito a parlamentares de partidos de esquerda e a alguns parlamentares de partidos de centro da região Nordeste - em que Lula possuía popularidade elevada e em que os governadores possuíam estreita ligação com a esquerda.

Em 12 de maio, após mais de 20 horas de discussão, o Senado da República aprovou a instauração do processo de impeachment e Dilma Rousseff foi afastada do cargo provisoriamente, por 180 dias. O placar foi de 55 votos favoráveis ao afastamento e 22 votos contrários $^{190}$. Finalmente, em 31 de agosto, o Senado analisou o mérito do processo de impeachment e condenou Dilma Rousseff à perda do mandato. O resultado da votação foi ainda mais amplo: 61 votos favoráveis à condenação e 20 votos contrários ${ }^{191}$. Com a aprovação do impeachment, Dilma Rousseff perdeu o mandato presidencial e Michel Temer assumiu a presidência de forma definitiva. Os senadores, contudo, rejeitaram a pena de inabilitação da petista para o exercício de funções públicas.

\footnotetext{
190 Após mais de 20 horas, Senado aprova processo de impeachment e afasta Dilma. Disponível em: https://noticias.uol.com.br/politica/ultimas-noticias/2016/05/12/senado-aprova-processo-de-impeachment-eafasta-dilma-por-ate-180-dias.htm

${ }^{191}$ Senado aprova impeachment, Dilma perde mandato e Temer assume. Disponível em: http://g1.globo.com/politica/processo-de-impeachment-de-dilma/noticia/2016/08/senado-aprova-impeachmentdilma-perde-mandato-e-temer-assume.html
} 


\section{POR QUE DILMA CAIU?}

Nos capítulos anteriores, realizou-se breve retrospecto do governo Dilma Rousseff. As razões pelas quais a presidente não conseguiu concluir seu mandato presidencial, sendo destituída por meio do processo do impeachment, são muitas.

O cenário econômico adverso e os escândalos de corrupção com ampla cobertura midiática foram elementos fundamentais para despertar manifestações populares pela saída da presidente. A figura 14, do capítulo anterior, mostrou a trajetória da popularidade de Dilma Rousseff ao longo de seu mandato. Às vésperas da aprovação do impeachment pela Câmara dos Deputados, a reprovação ao governo estava ao redor de $70 \%$, enquanto a avaliação positiva encontrava-se próximo a $10 \%$.

Além do avanço da Operação Lava-Jato, que desgastou a presidente da República e seu partido, os indicadores econômicos já apresentavam deterioração importante, antes mesmo da reeleição em 2014, como pode ser observado nas figuras 17, 18 e 19, abaixo. O crescimento econômico foi próximo a zero em 2014 e em 2015 houve retração de quase 4\% no PIB. A inflação superou os dois dígitos em 2015, algo inédito desde que o PT assumiu a presidência da República. Até mesmo o desemprego, que atingiu o menor patamar em 2014, passou a subir com o cenário econômico adverso a partir de então.

Figura 17. PIB. Variação Anual.

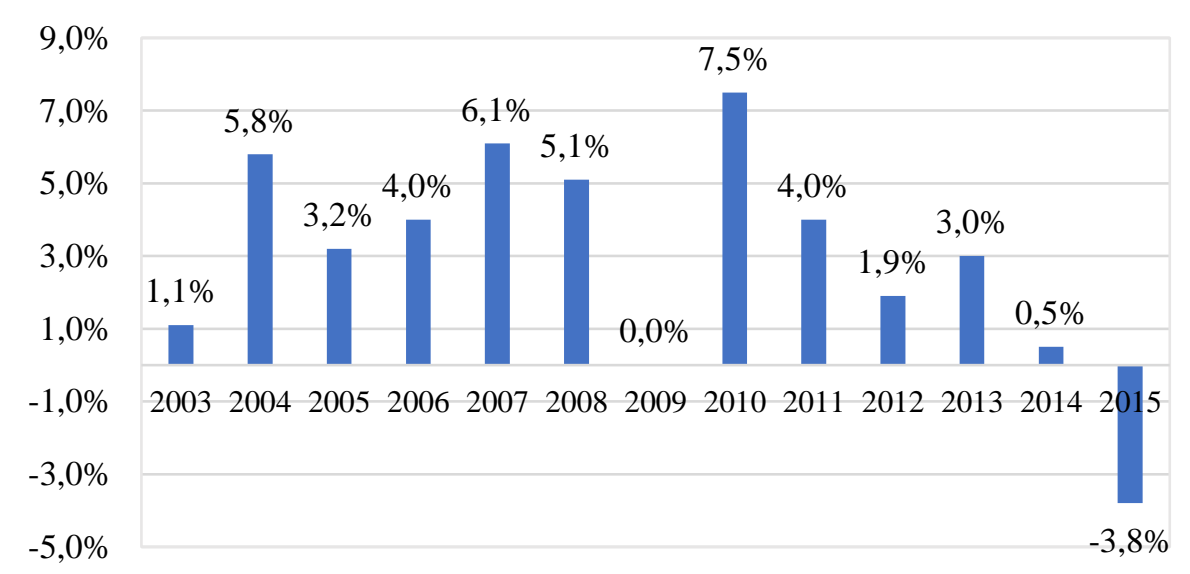

Fonte: IBGE. 
Figura 18. Inflação - IPCA. Variação Anual.

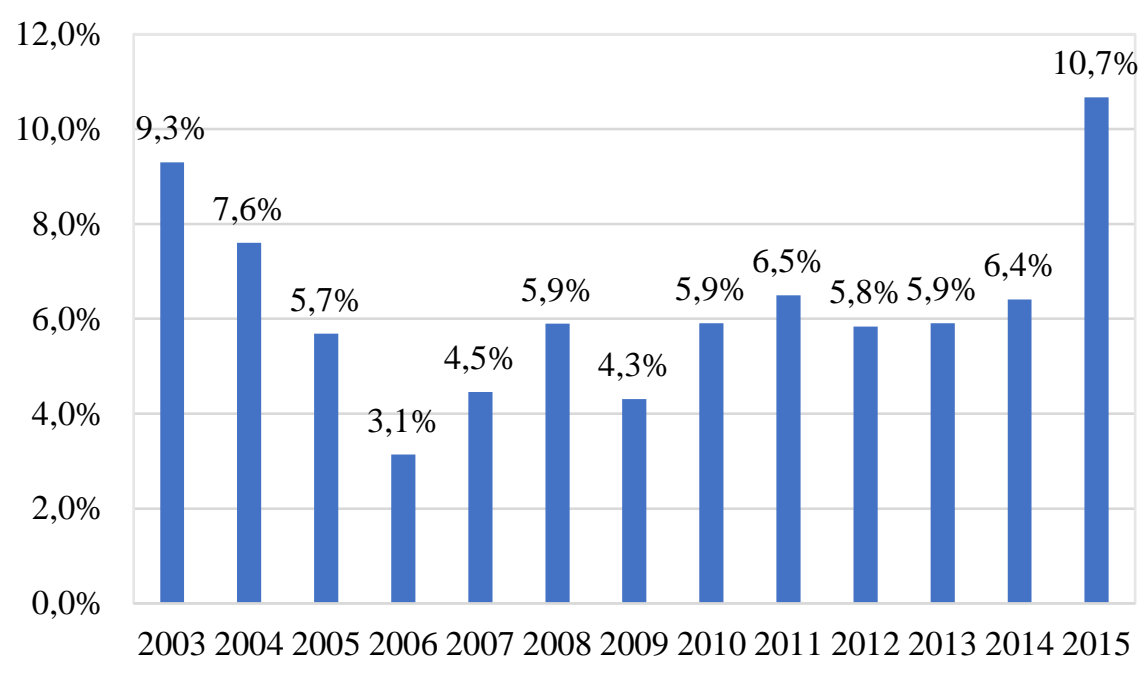

Fonte: IBGE.

Figura 19. Taxa de Desemprego - PME. Média Anual.

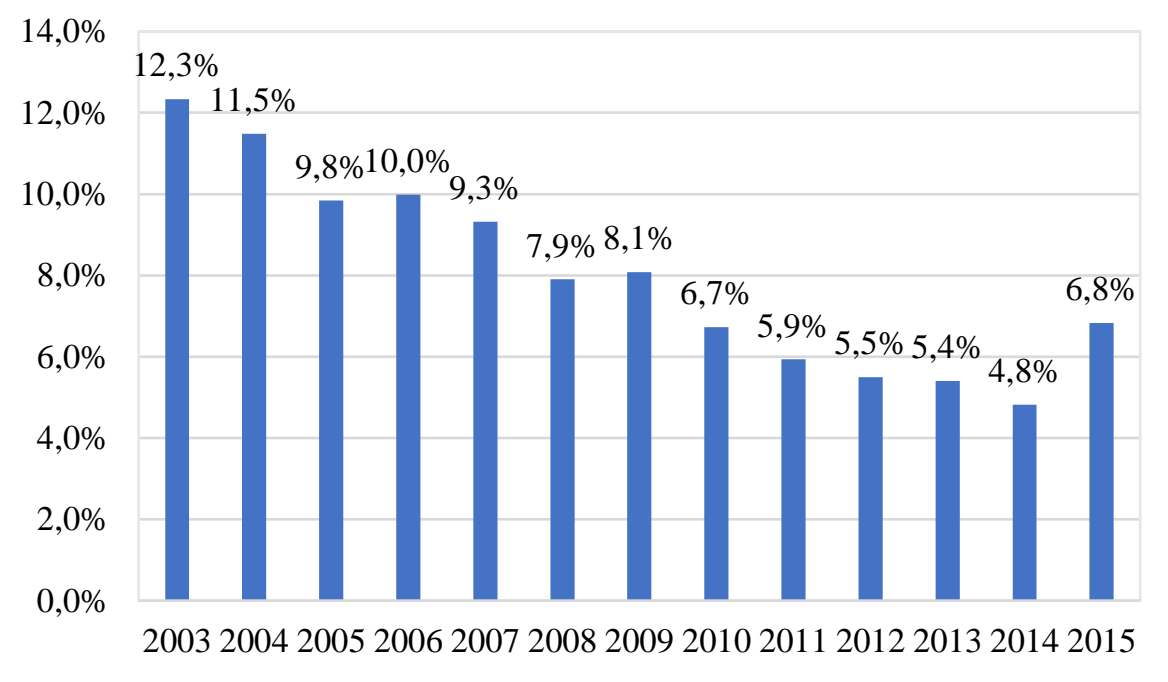

Fonte: IBGE.

Ao analisar as figuras acima, não é difícil encontrar as razões para a impopularidade de Dilma Rousseff após a sua reeleição. O quadro econômico adverso - que não esteve presente na crise do mensalão enfrentada por Lula em 2005, por exemplo - tornou o governo mais suscetível aos escândalos de corrupção divulgados pela mídia. Nesse ambiente, os protestos de rua foram frequentes ao longo de 2015 e 2016.

Em relação ao processo de impeachment, conforme a tese de Péraz-Liñán (2007) apresentada anteriormente, "as manifestações populares - mais que a ação legislativa - parecem ser a força principal que impulsiona a queda dos governos eleitos. A ação do Congresso provê o marco - o melhor marco possível - para a derrubada do governo, mas parece desempenhar um papel meramente reativo" (PÉREZ-LIÑÁN, 2007, p. 326, tradução nossa). 
Contudo, ao Poder Legislativo cabe autorizar o processo de destituição do presidente da República, não sendo possível desprezar a sua função. O Congresso poderá desprezar as evidências de crime de responsabilidade, mesmo diante de manifestações populares contra o presidente; ou determinar o afastamento presidencial, mesmo que as evidências de crime não estejam devidamente demonstradas. Em um caso, é possível falar na construção de escudo legislativo que blinda o presidente diante de ameaças a seu mandato; em outro, o impeachment pode ser empregado por um Legislativo hostil contra um presidente que adota estratégia de enfretamento ou isolamento (PEREZ-LIÑAN, 2007).

Nesse sentido, não se pode perder de vista o objetivo central dessa dissertação, qual seja avaliar as relações entre Executivo e Legislativo durante o mandato de Dilma Rousseff e explicar o comportamento do Congresso Nacional ao autorizar o afastamento da presidente, mesmo no contexto de uma coalizão de governo majoritária.

Segundo Péraz-Liñán, “o modelo de relações entre o Executivo e o Legislativo que o presidente estabelece no início do seu mandato, pode determinar a disposição dos legisladores de proteger o Executivo de um impeachment em um momento posterior" (PÉREZ-LIÑÁN, 2007, p. 267, tradução nossa). Como pode ser visto na figura 20, e como descrito ao longo da dissertação, o apoio legislativo à presidente seguiu trajetória de queda desde a sua posse e atingiu níveis dramáticos após a sua reeleição. Nesse contexto, o que se pretende neste capítulo é explicar a figura abaixo, de modo a sintetizar as razões que levaram Dilma Rousseff a perder gradualmente o apoio de sua base de sustentação - em outras palavras, apontar porque não foi possível a construção de escudo legislativo, de forma a blindar a presidente das ameaças a seu mandato.

Figura 20. Apoio ao Governo na Câmara dos Deputados - Partidos da Coalizão. Governos Lula e Dilma.

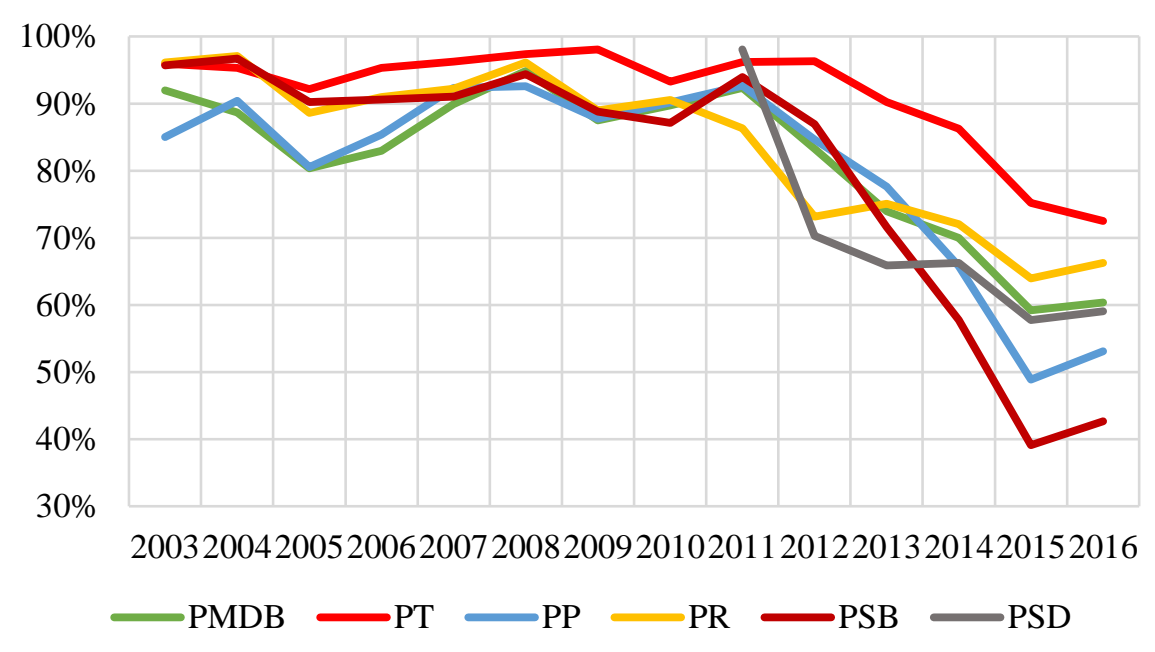

Fonte: Banco de dados do CEBRAP. 
De acordo com Figueiredo e Limongi (1999), no presidencialismo de coalizão, o chefe do Executivo precisa formar aliança que lhe garanta o suporte de uma maioria no Poder Legislativo. Para tanto, o presidente compõe seu ministério com os partidos aliados, distribuindo pastas e garantindo espaço na formulação de políticas públicas; em contrapartida, os partidos se comprometem com aprovação dos projetos do governo.

Na revisão da literatura, foi abordado o tema do gerenciamento da coalizão de governo pelo chefe do Executivo. De acordo com o estudo desenvolvido por Bertholini e Pereira (2017), conclui-se que coalizões com menos partidos, reduzida heterogeneidade ideológica e alocação proporcional de poder entre eles devem proporcionar menores custos e maior estabilidade aos gabinetes. Contudo, algumas dessas variáveis não dependem do presidente da República.

A fragmentação partidária aumentou no país nas últimas décadas, o que obriga o chefe do Executivo a construir uma coalizão com maior número de partidos, de modo a obter a maioria legislativa. Em 2002, por exemplo, os quatro maiores partidos da Câmara dos Deputados somavam mais de $60 \%$ dos parlamentares. Ao longo dos anos, como pode ser observado na figura 21, os maiores partidos perderam espaço. Da mesma forma, o PT - por ser um partido de centro-esquerda - precisou formar alianças com partidos mais conservadores para governar, o que implica em uma coalizão com maior heterogeneidade ideológica. Em sua melhor eleição legislativa, em 2002, o PT obteve menos de $18 \%$ das cadeiras da Câmara; os demais partidos de esquerda (PSB, PDT, PCdoB) obtiveram pouco mais de $10 \%$ das cadeiras.

Figura 21. Bancadas dos Partidos - Câmara dos Deputados.

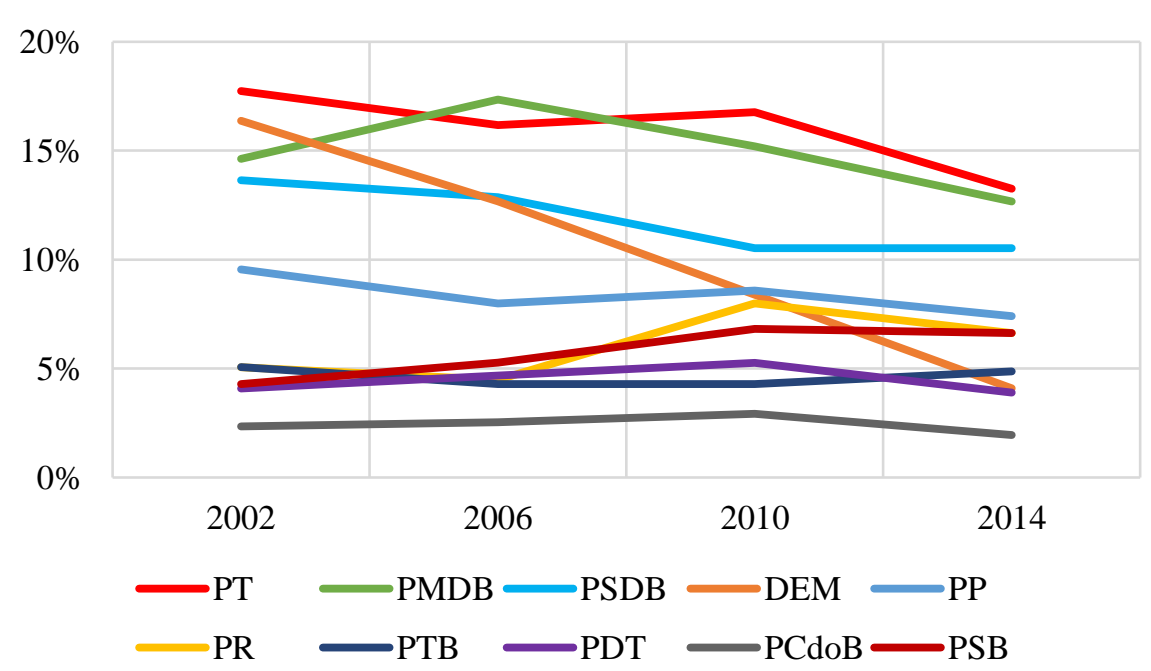

Fonte: Câmara dos Deputados. 
No que toca à alocação de poder entre os partidos da coalizão, por outro lado, a decisão é inteiramente do presidente da República. O chefe do poder Executivo não tem poder para determinar o número e o perfil dos partidos com representação no Congresso Nacional, mas cabe somente a ele a divisão de poder dentre os partidos da coalizão de governo.

Amorim Neto $(2000,2004)$ enfatiza a necessidade de gabinetes presidenciais representarem de forma proporcional os partidos da coalizão, mediante os respectivos pesos de cada um no Poder Legislativo. Com base na distribuição partidária dos ministérios, ele afirma que quanto mais coalescente (proporcionalidade entre as cotas ministeriais dos partidos e seus pesos parlamentares) for o gabinete, mais disciplinado será o comportamento dos parlamentares dos partidos da coalizão nas votações.

No que se refere à composição ministerial, o enfoque dessa dissertação foi o orçamento total de investimento que os partidos conseguem empenhar por meio dos ministros indicados por eles para compor o gabinete - uma vez que investimentos trazem maior visibilidade, podendo suscitar ganhos políticos aos agentes e partidos envolvidos. Foi essa a forma de mensurar o compartilhamento do poder entre os integrantes da coalizão.

A figura 22 mostra a divisão de poder entre os partidos da coalizão durante o governo do PT. Como dito anteriormente ao longo do trabalho, fica evidente a concentração de recursos de investimentos pelo PT, após a posse de Dilma Rousseff.

Figura 22. Investimentos dos Ministérios - Por Partido. Governos Lula e Dilma.

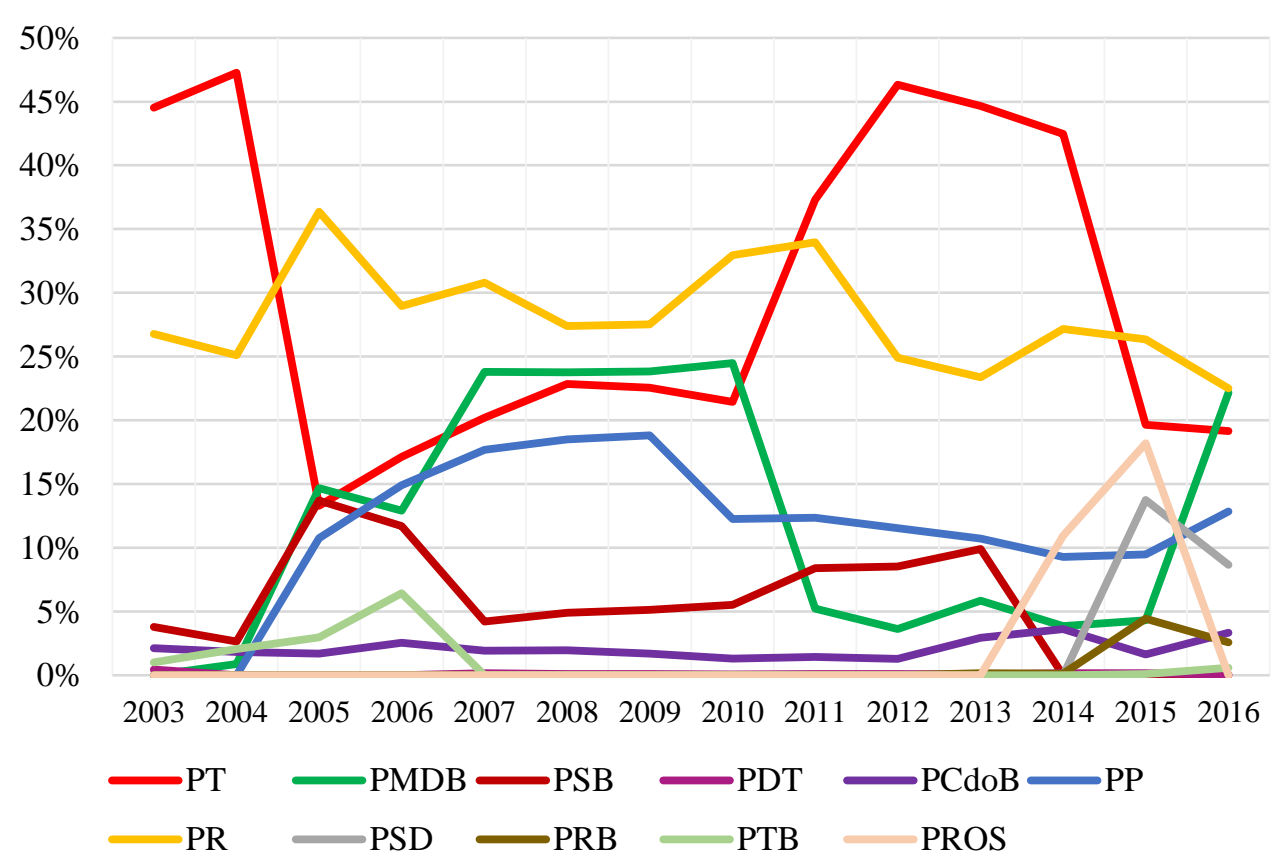

Fonte: Banco de dados do SIAFI. Valor empenhado, em porcentagem. 
O ex-presidente Lula também agiu da mesma forma ao tomar posse, ao concentrar os recursos nas mãos de ministros indicados por seu partido. Porém, gradualmente, Lula ampliou o espaço dos partidos aliados em seu ministério. Em 2004, ele incorporou o PMDB. Em 2005, após a crise do mensalão, o espaço do PMDB foi ampliado e o PP passou a fazer parte da coalizão. Após a sua reeleição, Lula firma aliança formal com o PMDB, que se tornou então o principal parceiro do PT na coalizão de governo.

Dito isso, Dilma Rousseff poderia ao longo de seu mandato - e à medida que as crises viessem à tona - ampliar o espaço dos partidos aliados em seu ministério. Como pode ser visto na figura 22, acima, isso não aconteceu. Ou, dito de outra forma, aconteceu somente ao final de 2015, às vésperas da abertura do processo de impeachment. Assim, é possível apontar uma forte conexão entre a divisão dos recursos entre os integrantes da coalizão e o apoio dos partidos ao governo no Congresso.

Contudo, não se pode explicar o destino de Dilma Rousseff somente pela divisão desproporcional de poder entre os partidos da coalizão. Esse é um dos motivos que justifica a queda no apoio legislativo à presidente da República, mas não o único.

A presidente, desde o início de seu primeiro mandato, adotou postura conflituosa em relação aos partidos. Em 2011, no episódio da faxina ministerial, a presidente demitiu - em cerca de seis meses - meia dúzia de ministros por suposto envolvimento em escândalos de corrupção. Dentre eles, dois presidentes de partidos aliados - no caso, o PDT e o PR. Além disso, em 2012, Dilma Rousseff demitiu a antiga diretoria da Petrobras - o que desagradou ao PMDB e ao PP, que haviam feito indicações para a companhia, como mais tarde se soube por meio de delações premiadas. Não cabe julgar a destreza dos atos da presidente da República. Contudo, a postura adotada por ela não poderia ter despertado a confiança entre seus aliados. $\mathrm{O}$ próprio PT criticou a condução de Dilma Rousseff, conforme foi descrito em capítulos anteriores. Nesse sentido, é preciso ressaltar as dificuldades que a presidente enfrentou com seu próprio partido - ou, ao menos, com grupos importantes dentro do PT.

Outro elemento que não pode ser desconsiderado são as divergências que envolveram o PT e os demais partidos da coalizão em determinadas votações. Em alguns temas, por exemplo no caso do Código Florestal e da reforma política, a posição ideológica do PT divergiu do restante da base aliada. A presidente poderia ter adotado postura de neutralidade. Contudo, Dilma Rousseff preferiu bancar as posições de seu partido, o que desgastou a relação com demais aliados.

Até 2012, a popularidade elevada da presidente poderia justificar a sua postura em relação aos partidos da coalizão. As manifestações de junho de 2013, contudo, deveriam ter 
servido como alerta para uma correção de rumo, no contexto da queda acentuada na avaliação do governo. Porém, mesmo diante disso, o publicitário João Santana continuou apostando na reeleição de Dilma Rousseff em primeiro turno, como se junho de 2013 não tivesse existido. Ao contrário de Lula, que soube aproveitar a crise do mensalão para reorganizar seu governo, a presidente não fez nenhum gesto aos partidos aliados.

Nas eleições de 2014, o PT apostou na conquista de governos estaduais e rompeu a aliança com o PMDB no Rio de Janeiro, por exemplo. A formalização da coligação eleitoral da presidente enfrentou dificuldades, como exposto detalhadamente em capítulos anteriores.

Ao tomar posse para seu segundo mandato, Dilma Rousseff novamente desperdiçou oportunidade para estabelecer nova relação com a sua base de sustentação. O PMDB permaneceu sub-representado e os partidos que obtiveram ganhos foram o PSD e o PROS, criados anteriormente com objetivo de tornar o governo menos dependente de partidos como o PMDB e o PP.

Não bastasse isso, Dilma Rousseff empreendeu esforços para impedir a eleição de Eduardo Cunha, então líder do PMDB, para a presidência da Câmara. Sem sucesso, o governo insistiu ao lado do presidente do PSD, Gilberto Kassab, na criação de um novo partido, o PL, para receber parlamentares aliados descontentes com seus respectivos partidos. A relação com o PMDB, que já não estava boa, ficou pior.

Nesse contexto, o governo sofreu uma série de derrotas no Congresso. Ainda em 2014, após as eleições, o governo federal assistiu à aprovação de decreto legislativo para derrubar o decreto presidencial que criou os conselhos populares. Em 2015, o governo foi surpreendido com a aprovação do Orçamento Impositivo, da PEC da Bengala e da redução da maioridade penal. Mesmo na votação das medidas provisórias do ajuste fiscal, o governo não se saiu bem. Apesar de ter aprovado as medidas, o Congresso aprovou emenda para derrubar o fator previdenciário. A partir disso, começaram a surgir as pautas-bomba. A PEC 443 - que vinculava os salários das carreiras da Advocacia-Geral da União e de delegados aos vencimentos dos ministros do STF - foi aprovada com 445 votos favoráveis na Câmara. Não há melhor exemplo de desarticulação por parte do Poder Executivo. Nesse cenário adverso, houve ainda afastamento entre a presidente Dilma Rousseff e o vice-presidente Michel Temer.

Somente em outubro de 2015, a presidente se dispôs a fazer reforma ministerial para aumentar a participação dos partidos aliados no ministério. Contudo, as mudanças vieram demasiado tarde. O avanço da Operação Lava-Jato - que no passado havia sido elogiada por Dilma Rousseff - jogou por terra as chances de sobrevivência do governo. Em novembro, o líder do governo no Senado, Delcídio do Amaral (PT), foi preso em flagrante. 
Em dezembro, o PT decidiu, surpreendentemente, votar a favor da abertura de processo contra Eduardo Cunha no Conselho de Ética da Câmara dos Deputados. Em meio ao clima desfavorável descrito acima, a decisão do partido soa incompreensível. Cunha, em reação, não só determinou a abertura do impeachment, como também, em demonstração de força, conseguiu eleger uma Comissão formada por integrantes da oposição para apreciar o processo.

A suspensão do impeachment pelo STF deu sobrevida ao governo, mas, mais uma vez, o desenrolar da Operação Lava-Jato fez desmoronar qualquer esperança de Dilma Rousseff sobreviver ao processo de afastamento. A prisão de seu publicitário, João Santana, e a condução coercitiva do ex-presidente Lula representaram desgaste inexorável ao governo. Por fim, a decisão do ministro Gilmar Mendes de impedir a posse de Lula como ministro-chefe da Casa Civil foi o tiro de misericórdia em Dilma Rousseff - que não possuía mais autoridade sequer para nomear um ministro de Estado.

Em suma, a reação da presidente à crise que atingiu seu governo foi extemporânea. Dilma Rousseff demorou a perceber a situação dramática em que se encontrava. Mais do que isso, é possível depreender que, ao menos em relação à articulação política, as suas ações acabaram conduzindo-a, gradualmente, ao impasse que a afastou da presidência. Desde que tomou posse, a presidente optou por não cultivar uma relação próxima com os partidos da coalizão, como explicitado acima. Quando a crise econômica e os escândalos de corrupção levaram milhões de pessoas às ruas pedindo sua destituição, Dilma Rousseff não resistiu. No auge de sua impopularidade - como fica evidente na figura 23, abaixo - e na ausência de escudo legislativo - como descrito ao longo do capítulo -, o impeachment tornou-se inevitável.

Figura 23. Avaliação de Governo. Governos Lula e Dilma.

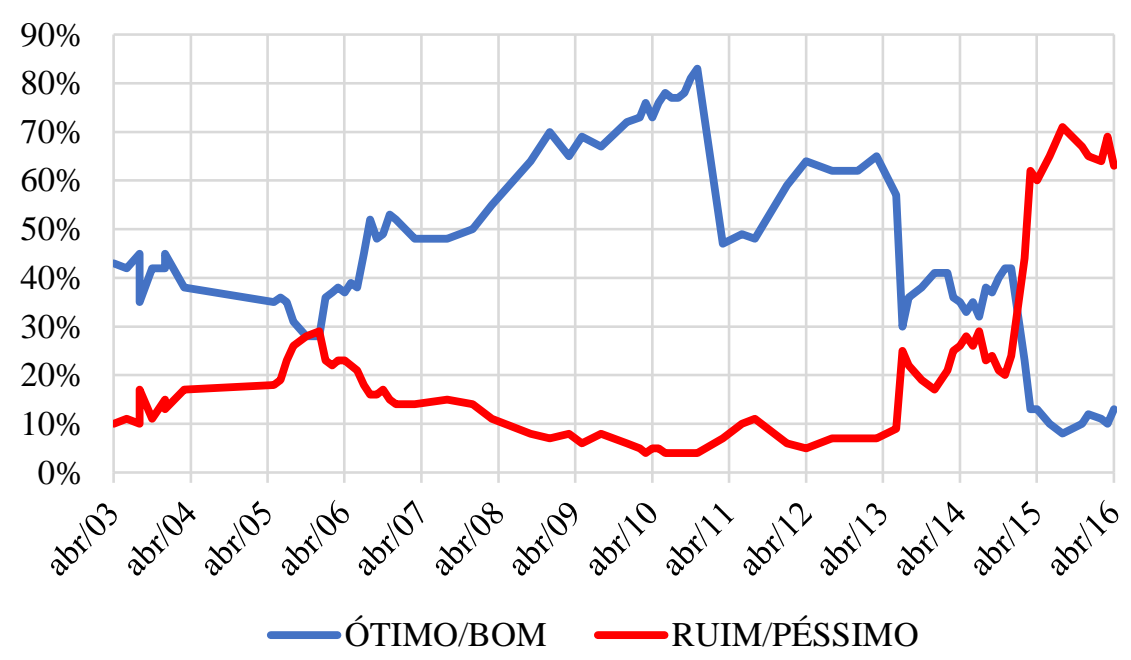

Fonte: Instituto Datafolha. 


\section{CONCLUSÃO}

A dissertação analisou a relação entre a presidente e os partidos da coalizão de governo durante o mandato de Dilma Rousseff. Apesar da reeleição e de coalizão majoritária no Congresso Nacional, a presidente foi afastada por meio de impeachment. Sem adentrar no mérito do processo, o trabalho avaliou as razões pelas quais a presidente não conseguiu construir escudo legislativo para lhe proteger em momentos de crise, de acordo com a tese de Pérez-Liñán (2007). Assim, em meio a circunstâncias adversas na economia e a escândalos de corrupção, a coalizão de governo ruiu e Dilma Rousseff acabou destituída pelo Legislativo.

Conforme foi apontado ao longo da dissertação, o apoio congressual ao governo caiu de forma contínua ao longo do tempo, o que foi atribuído, sobretudo, à desproporção na composição ministerial entre os partidos da coalizão e a conflitos permanentes existentes entre a presidente e seus aliados.

A conclusão predominante na literatura, a partir do trabalho de Figueiredo e Limongi (1999), é no sentido da viabilidade do presidencialismo de coalizão, na medida em que o chefe do Poder Executivo consiga formar coalizão de governo que reúna maioria legislativa. Para tanto, ele dispõe de instrumento importante: forma seu gabinete por meio da distribuição de pastas aos partidos aliados que, em contrapartida, se comprometem com a aprovação da agenda do governo no Legislativo.

Bertholini e Pereira (2017) afirmam que coalizões com menos partidos, reduzida heterogeneidade ideológica e alocação proporcional de poder entre eles devem proporcionar menores custos e maior estabilidade aos gabinetes. Tendo em vista que os dois primeiros fatores pouco dependem do chefe do Executivo, a principal variável a ser observada é a alocação de poder entre os partidos da coalizão. Por sua vez, Amorim Neto $(2000,2004)$ afirma que quanto mais coalescente for o gabinete ministerial, maior será o apoio dos partidos da coalizão ao governo no Congresso.

Assim, foi preciso decidir a melhor forma de medir o compartilhamento de poder entre os partidos da coalizão no gabinete ministerial. A variável utilizada foi o orçamento total de investimento que os partidos conseguem empenhar por meio dos ministros indicados por eles para compor o Gabinete - uma vez que investimentos trazem maior visibilidade, podendo suscitar ganhos políticos aos agentes e partidos envolvidos.

Como foi mostrado ao longo da dissertação, houve importante concentração de recursos de investimentos nas mãos do PT, após a posse de Dilma Rousseff. O ex-presidente Lula agiu de modo semelhante ao tomar posse, contudo, gradualmente, ampliou o espaço dos partidos 
aliados em seu ministério. Dilma Rousseff poderia, ao longo de seu mandato e à medida que as crises viessem à tona, aumentar o espaço dos partidos aliados, mas não foi isso que aconteceu.

Não se pode explicar, contudo, o afastamento de Dilma Rousseff somente pela divisão desproporcional de poder entre os partidos da coalizão. Esse é um dos motivos que explica a queda no apoio legislativo à presidente da República - e que, portanto, atrapalhou a formação do escudo legislativo -, mas não o único.

A presidente, desde a sua posse, adotou postura conflituosa em relação aos partidos. Em 2011, no episódio da faxina ministerial, vários ministros foram demitidos por suposto envolvimento em escândalos de corrupção - dentre eles, dois presidentes de partidos aliados, PDT e PR. Em 2012, Dilma Rousseff demitiu a diretoria da Petrobras, o que desagradou aos partidos da coalizão responsáveis pelas indicações dos antigos diretores.

Nas votações de determinados temas polêmicos, como o novo Código Florestal e a reforma política, o PT e os demais partidos da coalizão divergiram. A presidente, em vez de adotar postura de neutralidade, preferiu bancar as posições de seu partido.

Até 2012, em meio a popularidade elevada, Dilma Rousseff poderia justificar a sua postura em relação aos partidos da coalizão. Contudo, após as manifestações de junho de 2013, com a queda acentuada na avaliação do governo, deveria ter havido correção de rumo. Porém, ao contrário de Lula, que soube aproveitar a crise do mensalão para reorganizar seu governo, a presidente não fez nenhum gesto concreto aos partidos aliados.

Nas eleições de 2014, mesmo diante de um cenário nacional desafiador, o PT insistiu em priorizar as eleições estaduais e rompeu alianças com partidos da coalizão em nível regional. O caso mais emblemático foi o rompimento com o PMDB no Rio de Janeiro e o lançamento de candidatura própria no estado.

Ao tomar posse para seu segundo mandato, Dilma Rousseff desperdiçou nova oportunidade para reorganizar a sua base de sustentação. O PMDB permaneceu subrepresentado no ministério. Além disso, o Executivo se esforçou, sem sucesso, para impedir a eleição de Eduardo Cunha, então líder do PMDB, para a presidência da Câmara.

Nesse contexto, o governo sofreu uma série de derrotas no Congresso, como a aprovação do Orçamento Impositivo, da PEC da Bengala e da redução da maioridade penal. Durante as votações das medidas do ajuste fiscal, o Congresso extinguiu o fator previdenciário. A partir do segundo semestre de 2015, começaram a surgir as chamadas pautas-bomba, com reajustes elevados para determinadas categorias de servidores públicos.

Somente em outubro de 2015, a presidente anunciou reforma ministerial para aumentar a participação dos partidos aliados. Contudo, as mudanças vieram demasiado tarde em razão 
do avanço da Operação Lava-Jato - elogiada anteriormente por Dilma Rousseff. Em novembro, o líder do governo no Senado, Delcídio do Amaral (PT), foi preso em flagrante.

Em dezembro, o PT tomou a decisão de votar pela abertura de processo de cassação contra Eduardo Cunha no Conselho de Ética, o que levou o então presidente da Câmara dos Deputados a determinar a abertura do impeachment contra Dilma Rousseff.

A suspensão do impeachment pelo STF deu pequena sobrevida ao governo. A condução coercitiva de Lula e a decisão do ministro Gilmar Mendes de impedir a posse do ex-presidente como ministro-chefe da Casa Civil foram os episódios finais que antecederam ao impeachment. Com a decisão, Dilma Rousseff perdeu autoridade até mesmo para a nomeação de um ministro de Estado.

Em resumo, desde que tomou posse, a presidente optou por não construir uma relação sólida com os partidos da coalizão. Em diversas ocasiões, como por exemplo após as manifestações de junho de 2013 e após a sua reeleição, as oportunidades para reorganização na relação com os aliados foram desperdiçadas. Em 2015 e 2016, no contexto de crise econômica e escândalos de corrupção com ampla cobertura midiática, milhões de pessoas foram às ruas pela destituição de Dilma Rousseff. No auge da impopularidade presidencial e na ausência de escudo legislativo, o impeachment tornou-se resultado impossível de ser evitado. 


\section{REFERÊNCIAS}

ABRANCHES, S. H. A democracia brasileira vai bem, mas requer cuidados. In Reis Velloso, J. P. (Org.). Como vão o desenvolvimento e a democracia no Brasil? Rio de Janeiro: José Olympio, 2001.

ABRANCHES, S. H. Presidencialismo de coalizão: o dilema institucional brasileiro. Dados Revista de Ciências Sociais, Rio de Janeiro, v. 31, p. 5-38, 1988.

ALONSO, A. Junho de 2013 é um mês que não terminou. BBC Brasil. 3 jun 2018. Disponível em: < https://www.bbc.com/portuguese/brasil-44310600> Acesso em 30 jun 2018.

AMORIM NETO, O. Gabinetes presidenciais, ciclos eleitorais e disciplina legislativa no Brasil. Dados - Revista de Ciências Sociais, Rio de Janeiro, v. 43, n. 3, p. 479-519, 2000.

AMORIM NETO, O. O Poder Executivo, Centro de Gravidade do Sistema Político Brasileiro. Sistema Político Brasileiro: Uma Introdução. Rio de Janeiro: Fundação Konrad Adenauer, 2004.

AXELROD, R. Conflict of interest. Chicago: Markham, 1970.

BARON, D.; FEREJOHN, J. Bargaining and agenda formation in legislatures. The American Economic Review, v. 77, n. 2, p. 303-309, 1987.

BERTHOLINI, F.; PEREIRA, C. Pagando o preço de governar: custos de governabilidade no presidencialismo de coalizão brasileiro. Revista de Administração Pública, Rio de Janeiro, v. 51, n. 4, p. 528-550, jul.- ago. 2017.

BROSSARD, P. O impeachment. Porto Alegre: Livraria Globo, 1965.

CARRUBBA, C.; VOLDEN, C. Coalition politics and logrolling in legislative institutions. American Journal of Political Science, v. 44, n. 2, p. 255-271, 2000.

CARVAlHO, J. M. Cidadania no Brasil. São Paulo: Civilização Brasileira, 2001.

CHEIBUB, J. A.; PRZEWORSKI, A.; SAIEGH, S. M. Government Coalitions and Legislative Success under Presidentialism and Parliamentarism. British Journal of Political Science, v. 34, n. 4, p. 565-587, out. 2014.

DAHL, R. Poliarchy: Participation and Opposition. New Haven: Yale University Press, 1971.

FIGUEIREDO, A.; LIMONGI, F. A Crise Atual e o Debate Institucional. Revista Novos Estudos CEBRAP, São Paulo, v. 36, n. 3, p 79-97, 2017.

FIGUEIREDO, A.; LIMONGI, F. Executivo e Legislativo na nova ordem constitucional. Rio de Janeiro: FGV, 1999.

FREITAS, A. M. O Presidencialismo da Coalizão. Tese de Doutoramento. Faculdade de Filosofia, Letras e Ciências Humanas, Universidade de São Paulo, 2013. 
GAMSON, W. A theory of coalition formation. American Sociological Review, v. 26, n. 3, p. 373-382, 1961.

GROSECLOSE, T.; SNYDER, J. Buying supermajorities. American Political Science Review, v. 90, n. 2, p. 303-315, 1996.

KINZO, M. D. Partidos, eleições e democracia no Brasil pós-1985. Dados - Revista de Ciências Sociais, Rio de Janeiro, v. 19, n. 54, p. 23-41, 2004.

LAMOUNIER, B. Estrutura institucional e governabilidade na década de 90. In Reis Velloso, J. P. (Org.). O Brasil e as reformas políticas. Rio de Janeiro: José Olympio, 1992.

LAVER, M.; SCHOFIELD, N. Multiparty government: The politics of coalition in Europe. University of Michigan Press, 1998.

LEAL, V. N. Coronelismo, Enxada e Voto. São Paulo: Alfa-Ômega, 1975.

LIJPHART, A. Modelos de Democracia: Desempenho e Padrões de Governo em 36 Países. Rio de Janeiro: Civilização Brasileira, 2003.

LIMONGI, F. Impedindo Dilma. Revista Novos Estudos CEBRAP, São Paulo, n. especial, p. 5-13, 2017.

LINZ, J. Presidential or parliamentary democracy: does it make a difference? In Linz, J.; Valenzuela, A. (eds.). The failure of presidential democracy: the case of Latin America. Baltimore: Johns Hopkins University Press, 1994.

MARTIN, L.; VANBERG, G. Parliaments and Coalitions: The Role of Legislative Institutions in Multiparty Governance. Oxford University Press, 2011.

MORELLI, M.; MONTERO, M. The demand bargaining set: general characterization and application to majority games. Games and Economic Behavior, v. 42, n. 1, p. 137-155, jan. 2003.

NICOLAU, J. História do Voto no Brasil. Rio de Janeiro: Jorge Zahar Editora, 2002.

PEREIRA, C. O PT não sabe fazer coalizão de governo. Revista Época. 20 dez 2014. Disponível em: <https://epoca.globo.com/tempo/noticia/2014/12/carlos-pereira-o-pt-nao-sabefazer-bcoalizao-de-governob.html> Acesso em 30 jun 2018.

PERÉZ-LIÑÁN, A. Presidential Impeachment and the New Political Instability in Latin America. New York: Cambridge University Press, 2007.

PINHEIRO, D. A afilhada rebelde. Revista Piauí. Edição 97. Outubro de 2014. Disponível em: <https://piaui.folha.uol.com.br/materia/a-afilhada-rebelde> Acesso em 30 jun 2018.

PRAÇA, S.; FREITAS, A.; HOEPERS, B. Political Appointments and Coalition Management in Brazil, 2007-2010. Journal of Politics in Latin America, v. 3, n. 2, p. 141-172, 2011.

PRZEWORSKI, A.; LIMONGI, F.; CHEIBUB, J. A.; ALVAREZ, M. E. Democracy and development: political institutions and well-being in the world, 1950-1990. New York: Cambridge University Press, 2000. 
RIKER, W. The theory of political coalitions. New Haven: Yale University Press, 1962.

SILVA, M. B. O Mistério dos Ministérios: A Governança da Coalizão no Presidencialismo

Brasileiro. Tese de Doutoramento. Universidade Federal de Pernambuco, 2014.

SCHUMPETER, J. Capitalismo, socialismo e democracia. Rio de Janeiro: Fundo de Cultura, 1961.

SWAAN, A. de. Coalition theories and cabinet formations. Amsterdam: Elsevier, 1973.

\section{REFERÊNCIAS - PERIÓDICOS}

A MUDANÇA do discurso de Dilma sobre a Lava Jato em oito frases. Nexo Jornal. Disponível em <https://www.nexojornal.com.br/expresso/2016/03/19/A-mudan\%C3\%A7a-do-discursode-Dilma-sobre-a-Lava-Jato-em-oito-frases> Acesso em 30 jun 2018.

ACM declara voto em Lula no $2^{\circ}$ turno. Folha de S. Paulo. Disponível em <https://www1.folha.uol.com.br/fsp/brasil/fc0810200226.htm> Acesso em 30 jun 2018.

ACORDO Dilma-Renan envolve também a aprovação do nome de Janot no Senado. Portal G1. Disponível em <http://g1.globo.com/politica/blog/matheus-leitao/post/acordo-dilmarenan-envolve-tambem-aprovacao-do-nome-de-janot-no-senado.html > Acesso em 30 jun 2018.

ALDO vence, dá gás a Lula e esperança aos "mensaleiros". Folha de S. Paulo. Disponível em <http://www1.folha.uol.com.br/fsp/brasil/fc2909200502.htm> Acesso em 30 jun 2018.

ALFREDO NASCIMENTO renuncia à presidência do PR e vota por impeachment. Valor Econômico. Disponível em <https://www.valor.com.br/politica/4527515/alfredo-nascimentorenuncia-presidencia-do-pr-e-vota-por-impeachment> Acesso em 30 jun 2018.

ALFREDO NASCIMENTO rompe com o governo Dilma e declara independência do PR. O Globo. Disponível em <https://oglobo.globo.com/politica/alfredo-nascimento-rompe-comgoverno-dilma-declara-independencia-do-pr-2690023> Acesso em 30 jun 2018.

ALIADO do Planalto, Picciani é reeleito líder do PMDB na Câmara. Portal G1. Disponível em $<$ http://g1.globo.com/politica/noticia/2016/02/aliado-do-planalto-picciani-e-reeleito-lider-dopmdb-na-camara.html> Acesso em 30 jun 2018.

APESAR de ala dissidente, PMDB aprova apoio a Dilma nas eleições. Portal G1. Disponível em <http://g1.globo.com/distrito-federal/eleicoes/2014/noticia/2014/06/apesar-de-aladissidente-pmdb-aprova-apoio-dilma-nas-eleicoes.html> Acesso em 30 jun 2018.

APOIO a Lula cai; Serra ganharia eleição. Folha de S. Paulo. Folha de S. Paulo. Disponível em <https://www1.folha.uol.com.br/fsp/brasil/fc1208200504.htm> Acesso em 30 jun 2018.

APÓS avanço de 'pauta-bomba', Cunha fala em base 'deteriorada'. Portal G1. Disponível em $<$ http://g1.globo.com/politica/noticia/2015/08/apos-avanco-de-pauta-bomba-cunha-fala-embase-deteriorada.html> Acesso em 30 jun 2018. 
APÓS mais de 20 horas, Senado aprova processo de impeachment e afasta Dilma. Portal UOL. Disponível em <https://noticias.uol.com.br/politica/ultimas-noticias/2016/05/12/senadoaprova-processo-de-impeachment-e-afasta-dilma-por-ate-180-dias.htm> Acesso em 30 jun 2018.

APÓS ser chamado de 'vendido', Nogueira aprova apoio a Dilma em reunião secreta da Executiva do PP. O Globo. Disponível em <https://oglobo.globo.com/brasil/apos-serchamado-de-vendido-nogueira-aprova-apoio-dilma-em-reuniao-secreta-da-executiva-do-pp13013800> Acesso em 30 jun 2018.

APROVADA reforma do Código Florestal; ruralistas impõem derrota ao governo. Portal Estadão. Disponível em <http://www.estadao.com.br/noticias/geral,aprovada-reforma-docodigo-florestal-ruralistas-impoem-derrota-ao-governo-imp-,865402> Acesso em 30 jun 2018.

AS QUASE 50 horas de MP dos Portos na Câmara e no Senado. Portal G1. Disponível em $<$ http://g1.globo.com/politica/noticia/2013/05/quase-50-horas-de-mp-dos-portos-na-camara-eno-senado.html> Acesso em 30 jun 2018.

BANCADA do PMDB aprova moção de solidariedade e defende Eduardo Cunha. Portal da

Câmara dos Deputados. Disponível em

<http://www2.camara.leg.br/camaranoticias/noticias/politica/463426-bancada-do-pmdbaprova-mocao-de-solidariedade-e-defende-eduardo-cunha.html> Acesso em 30 jun 2018.

BANCADAS partidárias sofreram 50 mudanças em 2003. Portal da Câmara dos Deputados. Disponível em <http://www2.camara.leg.br/agencia/noticias/44044.html> Acesso em 30 jun 2018.

BASE fez acordo para que PTB e PSD comandem comissão, diz Guimarães. Portal G1. Disponível em <http://g1.globo.com/politica/processo-de-impeachment-dedilma/noticia/2016/03/base-fez-acordo-para-que-ptb-e-psd-comandem-comissao-dizguimaraes.html> Acesso em 30 jun 2018.

BATE-BOCA no Congresso derruba ministro e ofusca pacote de Dilma. Portal El Pais. Disponível em <https://brasil.elpais.com/brasil/2015/03/18/politica/1426717627_669791.html> Acesso em 30 jun 2018.

"BLOCÃO" impõe nova derrota ao governo e convoca dez ministros. Gazeta do Povo. Disponível em <http://www.gazetadopovo.com.br/vida-publica/blocao-impoe-nova-derrotaao-governo-e-convoca-dez-ministros-1tf6d3mm0gq95yfhao60ke1ji> Acesso em 30 jun 2018.

CÂMARA aprova emenda que cria alternativa ao fator previdenciário. Portal da Câmara dos Deputados. Disponível em <http://www2.camara.leg.br/camaranoticias/noticias/trabalho-eprevidencia/487925-camara-aprova-emenda-que-cria-alternativa-ao-fator-

previdenciario.html> Acesso em 30 jun 2018.

CÂMARA aprova PEC do orçamento impositivo em $1^{\circ}$ turno. Portal da Câmara dos Deputados.

Disponível

em 
<http://www2.camara.leg.br/camaranoticias/noticias/politica/479575-camara-aprova-pec-doorcamento-impositivo-em-1-turno.html> Acesso em 30 jun 2018.

CÂMARA aprova projeto de lei que dificulta a fusão de partidos. Portal G1. Disponível em $<$ http://g1.globo.com/politica/noticia/2015/02/camara-aprova-projeto-de-lei-que-dificultafusao-de-partidos.html> Acesso em 30 jun 2018.

CÂMARA autoriza instauração de processo de impeachment de Dilma com 367 votos a favor e 137 contra. Portal da Câmara dos Deputados. Disponível em <http://www2.camara.leg.br/camaranoticias/noticias/politica/507325-camara-autorizainstauracao-de-processo-de-impeachment-de-dilma-com-367-votos-a-favor-e-137contra.html> Acesso em 30 jun 2018.

CÂMARA passa regra que impede Dilma de indicar 5 nomes ao STF. Portal El Pais. Disponível em <https://brasil.elpais.com/brasil/2015/05/06/politica/1430874775_545044.html> Acesso em 30 jun 2018.

CARDOZO vai para a AGU e aliado de Wagner assume Ministério da Justiça. Portal Estadão. Disponível em <http://politica.estadao.com.br/noticias/geral,dilma-tenta-manter-cardozo-naagu,10000018802> Acesso em 30 jun 2018.

CASA CIVIL confirma pedido de demissão de Eliseu Padilha. Portal G1. Disponível em <http://g1.globo.com/politica/noticia/2015/12/casa-civil-confirma-pedido-de-demissao-deeliseu-padilha.html> Acesso em 30 jun 2018.

COM 46 votos, Eduardo Cunha é eleito líder do PMDB na Câmara. Folha de S. Paulo. Disponível em <http://www1.folha.uol.com.br/poder/2013/02/1225296-com-46-votoseduardo-cunha-e-eleito-lider-do-pmdb-na-camara.shtml> Acesso em 30 jun 2018.

COM APOIO do PT, Robinson Faria (PSD) é eleito governador no RN. Revista Isto É. Disponível

<https://istoe.com.br/389558_com+apoio+do+pt+robinson+faria+psd+e+eleito+governador+ no+rn> Acesso em 30 jun 2018.

COM PMDB à frente, base aliada se rebela, e Dilma busca socorro de Lula. Portal Estadão. Disponível em <http://politica.estadao.com.br/noticias/eleicoes,com-pmdb-a-frente-basealiada-se-rebela-e-dilma-busca-socorro-de-lula-imp-,842970> Acesso em 30 jun 2018.

COMISSÃO da Câmara aprova processo de impeachment de Dilma. Portal G1. Disponível em $<$ http://g1.globo.com/politica/processo-de-impeachment-de-dilma/noticia/2016/04/comissaoda-camara-aprova-processo-de-impeachment-de-dilma.html> Acesso em 30 jun 2018.

COMO O PMDB do Rio se tornou boia de salvação de Dilma. BBC Brasil. Disponível em <http://www.bbc.com/portuguese/noticias/2016/02/160216_rousseff_pmdb_ms> Acesso em 30 jun 2018.

CONGRESSO aprova mudança na meta fiscal de 2014, após 18 horas. Valor Econômico. Disponível em <http://www.valor.com.br/politica/3804386/congresso-aprova-mudanca-nameta-fiscal-de-2014-apos-18-horas> Acesso em 30 jun 2018. 
CONGRESSO derruba veto de Dilma sobre royalties de petróleo. O Globo. Disponível em $<$ https://oglobo.globo.com/economia/congresso-derruba-veto-de-dilma-sobre-royalties-depetroleo-7767366> Acesso em 30 jun 2018.

CONTRA CRISE, Dilma entrega a articulação política a vice, do PMDB. Portal El Pais. Disponível em <https://brasil.elpais.com/brasil/2015/04/08/politica/1428452392_198425.html> Acesso em 30 jun 2018.

CONVENÇÃO do PMDB decide que partido não terá candidato a presidente. Gazeta do Povo. Disponível em <https://www.gazetadopovo.com.br/vida-publica/convencao-do-pmdb-decideque-partido-nao-tera-candidato-a-presidente-a0urn117e9sn5uugerc3dbqdq/> Acesso em 30 jun 2018.

CRESCE o movimento "volta Lula", mas o ex-presidente nega candidatura. Portal El Pais. Disponível em <https://brasil.elpais.com/brasil/2014/04/09/politica/1397000108_059210.html> Acesso em 30 jun 2018.

CRIAÇÃO do PSD provoca baixa na oposição, e DEM é o partido que mais perde. O Globo. Disponível em <https://oglobo.globo.com/politica/criacao-do-psd-provoca-baixa-na-oposicaodem-o-partido-que-mais-perde-2796958> Acesso em 30 jun 2018.

CUNHA consegue nova virada e Câmara aprova redução da maioridade penal. BBC Brasil. Disponível em <http://www.bbc.com/portuguese/noticias/2015/07/150702_reducao_maioridade_aprovada_m s_tp> Acesso em 30 jun 2018.

CUNHA reúne 'blocão' para tentar isolar PT na Câmara. Folha de S. Paulo. Disponível em <http://www1.folha.uol.com.br/poder/2014/11/1542321-cunha-reune-blocao-para-tentarisolar-pt-na-camara.shtml> Acesso em 30 jun 2018.

DEMITIDO da articulação, Pepe Vargas deve assumir Direitos Humanos. Folha de S. Paulo. Disponível em <http://www1.folha.uol.com.br/poder/2015/04/1613624-demitido-daarticulacao-pepe-vargas-deve-assumir-direitos-humanos.shtml> Acesso em 30 jun 2018.

DEPOIS de 'afronta', PMDB vai antecipar reunião para decidir rompimento com governo. Portal Estadão. Disponível em <http://politica.estadao.com.br/noticias/geral,depois-deafronta--pmdb-vai-antecipar-reuniao-para-decidir-rompimento-com-governo,10000021794> Acesso em 30 jun 2018.

DEPOIS de deixarem o PSB, Cid e Ciro Gomes anunciam filiação ao PROS. Portal Estadão. Disponível em <https://politica.estadao.com.br/noticias/geral,depois-de-deixarem-o-psb-cid-eciro-gomes-anunciam-filiacao-ao-pros,1081157> Acesso em 30 jun 2018.

DEPUTADOS derrubam decreto dos conselhos populares. Portal da Câmara dos Deputados. Disponível em <http://www2.camara.leg.br/camaranoticias/noticias/politica/476677deputados-derrubam-decreto-dos-conselhos-populares.html> Acesso em 30 jun 2018. 
DEPUTADOS do PDT criticam escolha de Brizola Neto. O Globo. Disponível em $<$ https://oglobo.globo.com/brasil/deputados-do-pdt-criticam-escolha-de-brizola-neto4777024> Acesso em 30 jun 2018.

DILMA a Picciani: Castro e Pansera ocuparão Saúde e Ciência. Revista Exame. Disponível em <https://exame.abril.com.br/brasil/dilma-a-picciani-castro-e-pansera-ocuparao-saude-eciencia/> Acesso em 30 jun 2018.

DILMA agradece ao PMDB e elogia Michel Temer por articular apoio. Portal G1. Disponível em <http://g1.globo.com/distrito-federal/eleicoes/2014/noticia/2014/06/dilma-agradece-aopmdb-e-elogia-michel-temer-por-articular-apoio.html> Acesso em 30 jun 2018.

DILMA anuncia reforma com redução de 39 para 31 ministérios. Portal G1. Disponível em $<$ http://g1.globo.com/politica/noticia/2015/10/dilma-anuncia-reducao-de-39-para-31-pastasna-reforma-ministerial.html> Acesso em 30 jun 2018.

DILMA aumenta peso político do PMDB e amarra PDT ao projeto de reeleição. Portal Estadão. Disponível em <https://politica.estadao.com.br/noticias/eleicoes,dilma-aumentapeso-politico-do-pmdb-e-amarra-pdt-ao-projeto-de-reeleicao-imp-,1009371> Acesso em 30 jun 2018.

DILMA decide nomear Henrique Alves para o Turismo Portal G1. Disponível em $<$ http://g1.globo.com/politica/blog/blog-do-camarotti/post/dilma-decide-nomear-henriquealves-para-o-turismo.html> Acesso em 30 jun 2018.

DILMA defende coalização em posse de ministros. Portal Estadão. Disponível em $<$ https://politica.estadao.com.br/noticias/eleicoes,dilma-defende-coalizacao-em-posse-deministros-imp-,1009755> Acesso em 30 jun 2018.

DILMA desmente Cabral e diz que ainda não escolheu ministro da Saúde. Portal Estadão. Disponível em <https://politica.estadao.com.br/noticias/geral,dilma-desmente-cabral-e-dizque-ainda-nao-escolheu-ministro-da-saude,648079> Acesso em 30 jun 2018.

DILMA 'deu corda' para Lava Jato 'sufocar' Lula, diz Palocci. Portal Terra. Disponível em $<$ https://www.terra.com.br/noticias/brasil/politica/dilma-deu-corda-para-lava-jato-sufocarlula-diz-palocci,66f760ea6f3cedcea1b2823120b37dc2ve4j3nrq.html> Acesso em 30 jun 2018.

DILMA distribui ministérios e garante vitória parcial em sessão do Congresso. Portal El Pais. Disponível em <https://brasil.elpais.com/brasil/2015/09/23/politica/1442977828_193938.html> Acesso em 30 jun 2018.

DILMA diz que investigações da Lava Jato podem mudar país para sempre. Portal G1. Disponível em <http://g1.globo.com/politica/operacao-lava-jato/noticia/2014/11/dilmadefende-petrobras-e-diz-que-o-que-deve-ser-condenado-sao-pessoas.html> Acesso em 30 jun 2018.

'DILMA faz agora o que deveria ter feito em novembro', diz Lula sobre reforma ministerial. Portal Estadão. Disponível em <http://politica.estadao.com.br/noticias/geral,dilma-faz-agorao-que-deveria-ter-feito-em-novembro--diz-lula,1771951> Acesso em 30 jun 2018. 
DILMA nomeia Kassab e mais 12 para acomodar aliados no novo Governo. Portal El Pais. Disponível em <https://brasil.elpais.com/brasil/2014/12/23/politica/1419358115_778828.html> Acesso em 30 jun 2018.

DILMA proíbe ministro da Agricultura de falar sobre Código Florestal. Portal Estadão. Disponível em <https://politica.estadao.com.br/noticias/geral,dilma-proibe-ministro-daagricultura-de-falar-sobre-codigo-florestal,884251> Acesso em 30 jun 2018.

DILMA propõe 5 pactos e plebiscito para constituinte da reforma política. Portal G1. Disponível em <http://g1.globo.com/politica/noticia/2013/06/dilma-propoe-5-pactos-eplebiscito-para-constituinte-da-reforma-politica.html> Acesso em 30 jun 2018.

DILMA queria muitos na lista de Janot, desde que tivesse Aécio, diz Renan. Blog do Fernando Rodrigues. Disponível em $<$ https://fernandorodrigues.blogosfera.uol.com.br/2015/03/07/dilma-queria-muitos-na-listade-janot-desde-que-tivesse-aecio-diz-renan/> Acesso em 30 jun 2018.

DILMA rejeita indicações de Cunha e irrita PMDB do Rio. O Globo. Disponível em $<$ https://oglobo.globo.com/politica/dilma-rejeita-indicacoes-de-cunha-irrita-pmdb-do-rio2828295> Acesso em 30 jun 2018.

DILMA troca Mercadante por Jaques Wagner na Casa Civil. Folha de S. Paulo. Disponível em <http://www1.folha.uol.com.br/fsp/poder/234992-dilma-troca-mercadante-por-jaqueswagner-na-casa-civil.shtml> Acesso em 30 jun 2018.

DUDA diz que recebeu R $\$ 10,5$ milhões de caixa 2 em paraíso fiscal. Folha de S. Paulo. Disponível em <https://www1.folha.uol.com.br/folha/brasil/ult96u71339.shtml> Acesso em 30 jun 2018.

E A LAVA JATO pegou João Santana. Revista Época. Disponível em <https://epoca.globo.com/tempo/noticia/2016/02/e-lava-jato-pegou-joao-santana.html> Acesso em 30 jun 2018.

EDUARDO CUNHA anuncia rompimento com o governo e diz que é 'oposição'. Portal G1. Disponível em <http://g1.globo.com/politica/noticia/2015/07/eduardo-cunha-anunciarompimento-politico-com-o-governo-dilma.html> Acesso em 30 jun 2018.

EDUARDO CUNHA autoriza abrir processo de impeachment de Dilma. Portal G1. Disponível em <http://g1.globo.com/politica/noticia/2015/12/eduardo-cunha-informa-que-autorizouprocesso-de-impeachment-de-dilma.html> Acesso em 30 jun 2018.

EDUARDO CUNHA deve vitória a Dilma. Blog do Kennedy. Disponível em $<$ http://www.blogdokennedy.com.br/eduardo-cunha-deve-vitoria-a-dilma/> Acesso em 30 jun 2018.

EDUARDO CUNHA é eleito para a liderança do PMDB na Câmara. Valor Econômico. Disponível em <https://www.valor.com.br/politica/2993906/eduardo-cunha-rj-e-eleito-paralideranca-do-pmdb-na-camara> Acesso em 30 jun 2018. 
EDUARDO CUNHA é eleito presidente da Câmara dos Deputados. Portal da Câmara dos Deputados.

Disponível

em <http://www2.camara.leg.br/camaranoticias/noticias/politica/481104-eduardo-cunha-e-eleitopresidente-da-camara-dos-deputados.html> Acesso em 30 jun 2018.

EDUARDO CUNHA vai para eleição com maioria de partidos. Portal Estadão. Disponível em <http://politica.estadao.com.br/noticias/geral,eduardo-cunha-vai-para-eleicao-commaioria-de-partidos,1627932> Acesso em 30 jun 2018.

EM ATRITO com o Planalto, Renan nomeia ex-ministro do Turismo como chefe de gabinete. Portal Estadão. Disponível em <http://politica.estadao.com.br/noticias/geral,em-atrito-com-oplanalto-renan-nomeia-ex-ministro-do-turismo-como-chefe-de-gabinete,1671064> Acesso em 30 jun 2018.

EM ÁUDIO, Temer fala como se Câmara já tivesse aprovado impeachment. Portal G1. Disponível em <http://g1.globo.com/politica/processo-de-impeachment-dedilma/noticia/2016/04/e-preciso-um-governo-de-salvacao-nacional-afirma-vice-micheltemer.html> Acesso em 30 jun 2018.

EM CRISE com o Planalto, base aliada exige mais diálogo e menos poder ao PT. Portal Estadão. Disponível em <https://politica.estadao.com.br/noticias/eleicoes,em-crise-com-oplanalto-base-aliada-exige-mais-dialogo-e-menos-poder-ao-pt-imp-,846898> Acesso em 30 jun 2018.

EM CRISE com o Planalto, base cobra novo modelo de relação com Dilma. Portal Estadão. Disponível em <https://politica.estadao.com.br/noticias/geral,em-crise-com-o-planalto-basecobra-novo-modelo-de-relacao-com-dilma,846709> Acesso em 30 jun 2018.

EM DOCUMENTO, PT recusa 'faxina' de Dilma e pede reforma contra corrupção. Portal Estadão. Disponível em <http://politica.estadao.com.br/noticias/geral,em-documento-ptrecusa-faxina-de-dilma-e-pede-reforma-contra-corrupcao,767312> Acesso em 30 jun 2018.

EM VOTAÇÃO aberta, Senado dá aval à prisão de Delcídio decretada pelo STF. Portal G1. Disponível em <http://g1.globo.com/politica/noticia/2015/11/em-votacao-aberta-senado-daaval-prisao-de-delcidio-decretada-pelo-stf.html> Acesso em 30 jun 2018.

ESPECIAL Lula: um governo de alianças. Diário do Grande ABC. Disponível em <https://www.dgabc.com.br/Noticia/286989/especial-lula-um-governo-de-aliancas> Acesso em 30 jun 2018.

ESQUERDA vai às ruas em manifestação contra impeachment, Cunha e Levy. Portal El Pais. Disponível em <https://brasil.elpais.com/brasil/2015/08/21/politica/1440124250_602504.html> Acesso em 30 jun 2018.

"FAXINA de Dilma" contra a corrupção poupa PT e varre siglas aliadas. Portal R7. Disponível em <https://noticias.r7.com/brasil/noticias/-faxina-de-dilma-contra-a-corrupcao-poupa-pt-evarre-siglas-aliadas-20120216.html> Acesso em 30 jun 2018. 
GABRIELLI será o novo presidente da Petrobras. Portal Estadão. Disponível em $<$ https://economia.estadao.com.br/noticias/geral,gabrielli-sera-o-novo-presidente-dapetrobras,20050718p8411> Acesso em 30 jun 2018.

GAROTINHO vence Rigotto, mas terá de esperar convenção do PMDB. Portal UOL. Disponível em <https://noticias.uol.com.br/ultnot/2006/03/20/ult27u54539.jhtm> Acesso em 30 jun 2018.

GEDDEL privilegia prefeitos do PMDB da Bahia. Folha de S. Paulo. Disponível em <https://www1.folha.uol.com.br/fsp/brasil/fc2310200823.htm> Acesso em 30 jun 2018.

GILBERTO KASSAB pede demissão do Ministério das Cidades, diz Planalto. Portal G1. Disponível em <http://g1.globo.com/politica/noticia/2016/04/gilberto-kassab-pede-demissaodo-ministerio-das-cidades.html > Acesso em 30 jun 2018.

GILMAR MENDES suspende posse de Lula como ministro e devolve caso a Moro. Portal Veja. Disponível em <https://veja.abril.com.br/brasil/gilmar-mendes-suspende-posse-de-lulacomo-ministro-e-devolve-caso-a-moro/> Acesso em 30 jun 2018.

GOVERNO aprova segunda medida do ajuste fiscal e leva 'bote' da oposição. Portal El Pais. Disponível em <https://brasil.elpais.com/brasil/2015/05/14/politica/1431567290_572799.html> Acesso em 30 jun 2018.

GOVERNO corteja aliados para anular formação de 'blocão'. Portal Estadão. Disponível em $<$ http://politica.estadao.com.br/noticias/eleicoes, governo-corteja-aliados-para-anularformacao-de-blocao-imp-,1138103> Acesso em 30 jun 2018.

GOVERNO DILMA vence o primeiro 'round' do ajuste fiscal na Câmara. Portal El Pais. Disponível em <https://brasil.elpais.com/brasil/2015/05/06/politica/1430867818_281084.html> Acesso em 30 jun 2018.

GOVERNO oferece Ministério da Saúde para evitar desembarque do PP. Folha de S. Paulo. Disponível em <http://www1.folha.uol.com.br/poder/2016/03/1755571-governo-ofereceministerio-da-saude-para-evitar-desembarque-do-pp.shtml> Acesso em 30 jun 2018.

HENRIQUE ALVES pede demissão do Ministério do Turismo. Portal G1. Disponível em $<$ http://g1.globo.com/jornal-nacional/noticia/2016/03/ministro-henrique-alves-pede-demissaodo-ministerio-do-turismo.html> Acesso em 30 jun 2018.

INDEPENDENTE, Severino Cavalcanti é eleito presidente da Câmara. Folha de S. Paulo. Disponível em <http://www1.folha.uol.com.br/folha/brasil/ult96u67210.shtml> Acesso em 30 jun 2018 .

JEFFERSON denuncia mesada paga pelo tesoureiro do PT. Folha de S. Paulo. Disponível em $<$ https://www1.folha.uol.com.br/fsp/brasil/fc0606200502.htm> Acesso em 30 jun 2018. 
JOÃO SANTANA, o homem que elegeu seis presidentes. Revista Época. Disponível em <https://epoca.globo.com/tempo/noticia/2013/10/bjoao-santanab-o-homem-que-elegeu-seispresidentes.html> Acesso em 30 jun 2018.

JUSTIÇA autoriza condução coercitiva de Lula e Okamotto para prestar depoimento. Portal Estadão. Disponível em <http://politica.estadao.com.br/blogs/fausto-macedo/pf-esta-nosenderecos-de-lula-e-fabio-luis-em-nova-fase-da-lava-jato/> Acesso em 30 jun 2018.

KASSAB funda PSD com promessa de apoio a Dilma. Folha de S. Paulo. Disponível em <https://www1.folha.uol.com.br/fsp/poder/po1404201105.htm> Acesso em 30 jun 2018.

LEIA a íntegra da carta enviada pelo vice Michel Temer a Dilma. Portal G1. Disponível em <http://g1.globo.com/politica/noticia/2015/12/leia-integra-da-carta-enviada-pelo-vice-micheltemer-dilma.html> Acesso em 30 jun 2018.

LEIA e ouça trechos do depoimento de Paulo Roberto Costa à Justiça. Folha de S. Paulo. Disponível em <https://www1.folha.uol.com.br/poder/2014/10/1529925-leia-trechos-dodepoimentos-de-paulo-roberto-costa-a-justica.shtml> Acesso em 30 jun 2018.

LEVY deixa Fazenda após 11 meses no cargo e sucessivas derrotas. Portal G1. Disponível em <http://g1.globo.com/economia/noticia/2015/12/levy-deixa-fazenda-apos-11-meses-no-cargoe-sucessivas-derrotas.html> Acesso em 30 jun 2018.

LÍDERES da base anunciam criação de 'superbloco' para pressionar Dilma. Portal G1. Disponível em <http://g1.globo.com/politica/noticia/2014/02/lideres-da-base-anunciamcriacao-de-superbloco-para-pressionar-dilma.html> Acesso em 30 jun 2018.

LULA anuncia nomes que vão compor seu ministério. Folha de S. Paulo. Disponível em <https://www1.folha.uol.com.br/folha/brasil/ult96u43892.shtml> Acesso em 30 jun 2018.

LULA defende Henrique Meirelles como vice de Dilma em 2010. Portal Infomoney. Disponível em <http://www.infomoney.com.br/mercados/noticia/1767283/lula-defendehenrique-meirelles-como-vice-dilma-2010> Acesso em 30 jun 2018.

LULA demite Olívio Dutra e vai nomear Márcio Fortes para Cidades. Folha de S. Paulo. Disponível em <https://www1.folha.uol.com.br/folha/brasil/ult96u70642.shtml> Acesso em 30 jun 2018.

LULA diz que errou na relação com Congresso. Folha de S. Paulo. Disponível em <https://www1.folha.uol.com.br/fsp/brasil/fc0811200610.htm> Acesso em 30 jun 2018.

LULA entrega pessoalmente ao Congresso propostas das reformas tributária e previdenciária. Portal do Senado. Disponível em $<$ https://www12.senado.leg.br/noticias/materias/2003/04/30/lula-entrega-pessoalmente-aocongresso-propostas-das-reformas-tributaria-e-previdenciaria> Acesso em 30 jun 2018.

LULA faz a primeira reforma ministerial. Portal UOL. Disponível em <https://noticias.uol.com.br/inter/efe/2004/01/23/ult1808u3761.jhtm> Acesso em 30 jun 2018. 
LULA se dá por vencido e Michel Temer será o vice de Dilma. Portal O Dia. Disponível em $<$ https://www.portalodia.com/noticias/politica/lula-se-da-por-vencido-e-michel-temer-sera-ovice-de-dilma-73875.html> Acesso em 30 jun 2018.

LULA tenta consolidar aliança de Dilma, mas PMDB ameaça levar crise ao Senado. Portal Estadão. Disponível em <http://politica.estadao.com.br/noticias/geral,lula-tenta-consolidaralianca-de-dilma-mas-pmdb-ameaca-levar-crise-ao-senado,1137585> Acesso em 30 jun 2018.

LULA tenta reverter paralisia da Câmara. Portal UOL. Disponível em <https://noticias.uol.com.br/ultnot/reuters/2005/05/13/ult27u48931.jhtm> Acesso em 30 jun 2018.

LULA vê candidatura de Lindbergh no RJ como irreversível. Congresso em Foco. Disponível em <https://congressoemfoco.uol.com.br/especial/noticias/lula-ve-candidatura-de-lindberghno-rj-como-irreversivel/> Acesso em 30 jun 2018.

MAIOR MANIFESTAÇÃO da história do País aumenta pressão por saída de Dilma. Portal Estadão. Disponível em <https://politica.estadao.com.br/noticias/geral,manifestacoes-emtodos-os-estados-superam-as-de-marco-do-ano-passado,10000021047> Acesso em 30 jun 2018.

MAIORIA apoia abertura de processo de impeachment, mostra Datafolha. Folha de S. Paulo. Disponível em <https://www1.folha.uol.com.br/poder/2015/04/1615424-maioria-querimpeachment-de-dilma-e-nao-conhece-vice.shtml> Acesso em 30 jun 2018.

MAIS TRIBUTOS e mais cortes: a conta da austeridade que o brasileiro vai pagar. Portal El Pais. Disponível em <https://brasil.elpais.com/brasil/2015/09/15/politica/1442271444_522241.html> Acesso em 30 jun 2018.

MANIFESTANTES fazem maior protesto nacional contra o governo Dilma. Portal G1. Disponível em <http://g1.globo.com/politica/noticia/2016/03/manifestacoes-contra-governodilma-ocorrem-pelo-pais.html> Acesso em 30 jun 2018.

MARTA rejeita dar vice ao PMDB e lança Rui Falcão. Folha de S. Paulo. Disponível em <http://www1.folha.uol.com.br/fsp/brasil/fc1303200423.htm> Acesso em 30 jun 2018.

MINEIRO ligado ao PT é nomeado presidente da Funasa. O Estado de Minas. Disponível em $<$ https://www.em.com.br/app/noticia/politica/2011/04/28/interna_politica,224272/mineiroligado-ao-pt-e-nomeado-presidente-da-funasa.shtml> Acesso em 30 jun 2018.

MINISTRO de Dilma até dias atrás, Mauro Lopes votará a favor do impeachment. O Globo. Disponível em <https://oglobo.globo.com/brasil/ministro-de-dilma-ate-dias-atras-maurolopes-votara-favor-do-impeachment-19109963> Acesso em 30 jun 2018.

MORO derruba sigilo e divulga grampo de ligação entre Lula e Dilma. Portal G1. Disponível em <http://g1.globo.com/pr/parana/noticia/2016/03/pf-libera-documento-que-mostra-ligacaoentre-lula-e-dilma.html> Acesso em 30 jun 2018. 
NÃO PEDIR IMPEACHMENT em 2005 foi maior erro da oposição na Era Lula, afirma líder do PSDB. Blog do Josias de Souza. Disponível em <https://josiasdesouza.blogosfera.uol.com.br/2012/12/14/nao-pedir-impeachment-em-2005foi-maior-erro-da-oposicao-na-era-lula-afirma-lider-do-psdb/> Acesso em 30 jun 2018.

'NÃO tem terceiro mandato', diz Lula. Portal Estadão. Disponível em <http://politica.estadao.com.br/noticias/geral,nao-tem-terceiro-mandato-diz-lula,373820> Acesso em 30 jun 2018.

NEGOCIAÇÃO PT-PL avança e já inclui programa de governo. Folha de S. Paulo. Disponível em <https://www1.folha.uol.com.br/fsp/brasil/fc1402200206.htm> Acesso em 30 jun 2018.

NOMEAÇÃO de ministro interino irrita PMDB. Revista Exame. Disponível em $<$ https://exame.abril.com.br/brasil/nomeacao-de-ministro-interino-irrita-pmdb $>$ Acesso em 30 jun 2018.

NOVO PARTIDO de Kassab amplia crise entre Dilma e PMDB. Portal Terra. Disponível em $<$ https://www.terra.com.br/noticias/brasil/politica/novo-partido-de-kassab-amplia-crise-entredilma-e-pmdb,1c83ffb11265c410VgnVCM10000098cceb0aRCRD.html> Acesso em 30 jun 2018.

O DUELO Levy-Rousseff. Portal El Pais. Disponível em <https://brasil.elpais.com/brasil/2015/03/30/opinion/1427741267_915296.html> Acesso em 30 jun 2018.

O JUlgAmento do mensalão dia a dia. Portal Terra. Disponível em $<$ https://www.terra.com.br/noticias/infograficos/mensalao-dia-a-dia> Acesso em 30 jun 2018.

O NEGOCIADOR Lula que tenta salvar o Governo Dilma do impeachment - Portal EI Pais. Disponível em <https://brasil.elpais.com/brasil/2016/04/09/politica/1460166122_568182.html> Acesso em 30 jun 2018.

“O QUE O presidente (Lula) me ofereceu foi aquela diretoria que fura poço e acha petróleo. É essa que eu quero”. O Globo. Disponível em <https://acervo.oglobo.globo.com/frases/o-quepresidente-lula-me-ofereceu-foi-aquela-diretoria-que-fura-poco-acha-petroleo-essa-que-euquero-9152017> Acesso em 30 jun 2018.

OPOSIÇÃO vence votação para comissão e STF suspende impeachment. BBC Brasil. Disponível

<http://www.bbc.com/portuguese/noticias/2015/12/151208_comissao_impeachment_ab>

Acesso em 30 jun 2018.

OS MINISTÉRIOS mais cobiçados pelos políticos do Brasil, segundo pesquisa inédita de Oxford. BBC Brasil. Disponível em <http://www.bbc.com/portuguese/brasil-43218087> Acesso em 30 jun 2018.

PADILHA troca ligado ao PMDB por petista em secretaria. Portal Último Segundo. Disponível em <https://ultimosegundo.ig.com.br/politica/padilha-troca-ligado-ao-pmdb-porpetista-em-secretaria/n1237937699550.html> Acesso em 30 jun 2018. 
PARA MANTER aliança com o PR, Dilma troca ministro dos Transportes. O Globo. Disponível em <https://oglobo.globo.com/brasil/para-manter-alianca-com-pr-dilma-trocaministro-dos-transportes-13009662> Acesso em 30 jun 2018.

PARTIDOS de esquerda discutem impeachment ou antecipação de eleições. Folha de S. Paulo. Disponível em <https://www1.folha.uol.com.br/folha/brasil/ult96u71383.shtml > Acesso em 30 jun 2018.

PARTIDOS se irritam com mudanças feitas por Graça na Petrobras. O Globo. Disponível em $<$ https://oglobo.globo.com/economia/partidos-se-irritam-com-mudancas-feitas-por-graca-napetrobras-4749680> Acesso em 30 jun 2018.

PEEMEDEBISTA do Maranhão ligado a Sarney é o novo ministro. Gazeta do Povo. Disponível em <https://www.gazetadopovo.com.br/vida-publica/peemedebista-do-maranhaoligado-a-sarney-e-o-novo-ministro-c96swezqpzk7wvf3pu9unsdou/> Acesso em 30 jun 2018.

PELO TWITTER, Eduardo Cunha diz que é preciso repensar aliança do PMDB com PT. Jornal GGN. Disponível em <https://jornalggn.com.br/noticia/pelo-twitter-eduardo-cunha-diz-que-epreciso-repensar-alianca-do-pmdb-com-pt> Acesso em 30 jun 2018.

PLANALTO anuncia Lula como novo ministro da Casa Civil. Portal G1. Disponível em <http://g1.globo.com/politica/noticia/2016/03/planalto-anuncia-lula-como-novo-ministro-dacasa-civil.html> Acesso em 30 jun 2018.

PLANALTO negocia com PMDB saída para votar lei da internet. Folha de S. Paulo. Disponível em <https://www1.folha.uol.com.br/poder/2014/03/1427039-planalto-negociacom-pmdb-saida-para-votar-lei-da-internet.shtml> Acesso em 30 jun 2018.

PMDB abraça bandeiras da oposição, como a redução de ministérios. Portal El Pais. Disponível em <https://brasil.elpais.com/brasil/2015/03/27/politica/1427416753_259569.html> Acesso em 30 jun 2018.

PMDB aprova participação no governo de coalizão de Lula. Portal G1. Disponível em <http://g1.globo.com/Noticias/Politica/0,,AA1370004-5601,00.html> Acesso em 30 jun 2018.

PMDB autoriza Eduardo Cunha a formar bloco para viabilizar eleição dele à presidência da Câmara. O Globo. Disponível em <https://oglobo.globo.com/brasil/pmdb-autoriza-eduardocunha-formar-bloco-para-viabilizar-eleicao-dele-presidencia-da-camara-14399894> Acesso em 30 jun 2018.

PMDB coloca Dilma contra a parede de olho em cargos e em 2018. Portal El Pais. Disponível em <https://brasil.elpais.com/brasil/2015/02/25/politica/1424904841_410520.html> Acesso em 30 jun 2018.

PMDB consegue Agricultura e passa a controlar cinco ministérios. Folha de S. Paulo. Disponível em <http://www1.folha.uol.com.br/folha/brasil/ult96u90301.shtml> Acesso em 30 jun 2018. 
PMDB decide deixar base governista do governo Lula. Folha de S. Paulo. Disponível em <https://www1.folha.uol.com.br/folha/brasil/ult96u66225.shtml> Acesso em 30 jun 2018.

PMDB decide desligar membros do partido que ocupem cargos de confiança. Folha de S. Paulo. Disponível em <https://www1.folha.uol.com.br/folha/brasil/ult96u70290.shtml> Acesso em 30 jun 2018.

PMDB desafia Dilma e devolve projeto que prevê ajuste fiscal. Portal El Pais. Disponível em $<$ https://brasil.elpais.com/brasil/2015/03/03/politica/1425423072_653232.html> Acesso em 30 jun 2018.

PMDB deve votar a favor de redução de tarifa de energia. O Estado de Minas. Disponível em $<$ https://www.em.com.br/app/noticia/politica/2012/12/10/interna_politica,335951/pmdb-devevotar-a-favor-de-reducao-de-tarifa-de-energia.shtml> Acesso em 30 jun 2018.

PMDB do Rio lança chapa 'Aezão' contra Dilma. Folha de S. Paulo. Disponível em $<$ https://www1.folha.uol.com.br/poder/2014/04/1440819-pmdb-do-rio-lanca-chapa-aezaocontra-dilma.shtml> Acesso em 30 jun 2018.

PMDB fica fora do ministério do governo Lula. Portal UOL. Disponível em $<$ https://noticias.uol.com.br/inter/reuters/2002/12/20/ult27u29752.jhtm> Acesso em 30 jun 2018.

PMDB insiste em quinto ministério no governo Dilma. Folha de S. Paulo. Disponível em <http://www1.folha.uol.com.br/fsp/poder/po0612201009.htm> Acesso em 30 jun 2018.

PMDB oficializa apoio ao petista Fernando Haddad. O Estado de Minas. Disponível em $<$ https://www.em.com.br/app/noticia/politica/2012/10/11/interna_politica,323015/pmdboficializa-apoio-ao-petista-fernando-haddad.shtml> Acesso em 30 jun 2018.

PMDB oficializa Michel Temer como vice na chapa de Dilma. Portal G1. Disponível em <http://g1.globo.com/especiais/eleicoes-2010/noticia/2010/06/pmdb-oficializa-michel-temercomo-vice-na-chapa-de-dilma.html> Acesso em 30 jun 2018.

PMDB promete obstrução à MP do Mais Médicos até minirreforma eleitoral ser votada. Portal EBC. Disponível em <http://www.ebc.com.br/noticias/politica/2013/10/pmdb-prometeobstrucao-a-mp-do-mais-medicos-ate-minirreforma-eleitoral-ser> Acesso em 30 jun 2018.

POR ACLAMAÇÃO, PMDB oficializa rompimento com governo Dilma. Portal G1. Disponível em <http://g1.globo.com/politica/noticia/2016/03/por-aclamacao-pmdb-oficializarompimento-com-governo-dilma.html> Acesso em 30 jun 2018.

POR UNANIMIDADE, STF confirma prisão de senador Delcídio. Portal UOL. Disponível em <https://noticias.uol.com.br/politica/ultimas-noticias/2015/11/25/em-sessaoextraordinaria-stf-confirma-prisao-de-senador-delcidio.htm> Acesso em 30 jun 2018.

PP anuncia apoio informal a Dilma, mas não cede tempo de TV. Portal G1. Disponível em <http://g1.globo.com/politica/noticia/2010/07/pp-anuncia-apoio-informal-a-dilma-mas-naocede-tempo-de-tv-1.html> Acesso em 30 jun 2018. 
PP e PRB anunciam apoio oficial a impeachment e enfraquecem base de Dilma. BBC Brasil. Disponível em <http://www.bbc.com/portuguese/noticias/2016/04/160412_prb_impeachment_rs> Acesso em 30 jun 2018.

PP fecha questão a favor do impeachment e punirá dissidentes. Valor Econômico. Disponível em <http://www.valor.com.br/politica/4525967/pp-fecha-questao-favor-do-impeachment-epunira-dissidentes $>$ Acesso em 30 jun 2018.

PRB rompe com Dilma e é primeiro partido a deixar base do governo. Portal R7. Disponível em <https://noticias.r7.com/brasil/prb-rompe-com-dilma-e-e-primeiro-partido-a-deixar-basedo-governo-17032016> Acesso em 30 jun 2018.

PRESIDENTE completa reforma ministerial. Folha de Londrina. Disponível em $<$ https://www.folhadelondrina.com.br/politica/presidente-completa-reforma-ministerial597422.html> Acesso em 30 jun 2018.

PRESIDENTE escolheu Lando por exclusão. Folha de S. Paulo. Disponível em <https://www1.folha.uol.com.br/fsp/brasil/fc2401200405.htm> Acesso em 30 jun 2018.

PRESIDENTE quer negociar com PMDB unido. Folha de S. Paulo. Disponível em <https://www1.folha.uol.com.br/fsp/brasil/fc0811200612.htm> Acesso em 30 jun 2018.

PRESSIONADO, Temer deixa a articulação política do governo. Portal Veja. Disponível em $<$ https://veja.abril.com.br/politica/pressionado-temer-deixa-a-articulacao-politica-dogoverno/> Acesso em 30 jun 2018.

PREVIDÊNCIA passa com votos da oposição e sem mudanças. Portal do Senado. Disponível em < <https://www2.senado.leg.br/bdsf/bitstream/handle/id/498819/2003-1127.pdf?sequence $=1>$ Acesso em 30 jun 2018.

PROMULGADA emenda constitucional do orçamento impositivo. Portal da Câmara dos Deputados. Disponível

<http://www2.camara.leg.br/camaranoticias/noticias/politica/483652-promulgada-emendaconstitucional-do-orcamento-impositivo.html> Acesso em 30 jun 2018.

PRÓXIMO de Dilma, Mendes Ribeiro, novo ministro da Agricultura, encarou PMDB gaúcho por ela. O Globo. Disponível em <https://oglobo.globo.com/politica/proximo-de-dilmamendes-ribeiro-novo-ministro-da-agricultura-encarou-pmdb-gaucho-por-ela-2688714> Acesso em 30 jun 2018.

PSB deixa governo Dilma e dá primeiro passo para candidatura de Campos. Gazeta do Povo. Disponível em <http://www.gazetadopovo.com.br/vida-publica/psb-deixa-governo-dilma-eda-primeiro-passo-para-candidatura-de-campos-cb6o536384rdsglp43ghami4u> Acesso em 30 jun 2018.

PSB oficializa retirada de candidatura de Ciro Gomes à Presidência. Portal G1. Disponível em <http://g1.globo.com/politica/noticia/2010/04/psb-oficializa-retirada-de-candidatura-de-cirogomes-presidencia.html> Acesso em 30 jun 2018. 
PSDB anuncia Geraldo Alckmin como candidato à Presidência. Portal UOL. Disponível em <https://noticias.uol.com.br/ultnot/politica/ultimas/2006/03/14/ult3453u86.jhtm> Acesso em 30 jun 2018.

PT decide votar contra Cunha, que pode deflagrar impeachment de Dilma. Folha de S. Paulo. Disponível em <http://www1.folha.uol.com.br/poder/2015/12/1713918-bancada-petistadecide-votar-contra-cunha-no-conselho-de-etica-da-camara.shtml> Acesso em 30 jun 2018.

PT e PMDB fecham acordo por chapa de Dilma Rousseff em 2010. Portal Terra. Disponível em <https://www.terra.com.br/noticias/brasil/politica/pt-e-pmdb-fecham-acordo-por-chapade-dilma-rousseff-em-2010,98096f7d7fc4b310VgnCLD200000bbcceb0aRCRD.html> Acesso em 30 jun 2018.

PT expulsa radicais do partido. Folha de S. Paulo. Disponível em <http://www1.folha.uol.com.br/folha/brasil/ult96u56445.shtml> Acesso em 30 jun 2018.

PTB e PSC formam bloco de olho no Ministério do Trabalho. Valor Econômico. Disponível em <https://www.valor.com.br/politica/2581442/ptb-e-psc-formam-bloco-de-olho-noministerio-do-trabalho> Acesso em 30 jun 2018.

RENAN renuncia à presidência do Senado para evitar perder mandato. Portal G1. Disponível em <http://g1.globo.com/noticias/politica/0,,mul203841-5601,00renan+renuncia+a+presidencia+do+senado.html> Acesso em 30 jun 2018.

RENAN volta do recesso parlamentar governista. Congresso em Foco. Disponível em $<$ http://congressoemfoco.uol.com.br/noticias/renan-volta-do-recesso-com-posturagovernista/> Acesso em 30 jun 2018.

RETROSPECTIVA 2011: Faxina ministerial abre espaço para reforma na Esplanada depois da saída de 7 ministros. Portal Estadão. Disponível em $<$ http://politica.estadao.com.br/noticias/geral,retrospectiva-2011-faxina-ministerial-abreespaco-para-reforma-na-esplanada,812647> Acesso em 30 jun 2018.

SAIBA o que são as 'pautas-bomba' nas mãos do Congresso contra o governo. Folha de $\mathbf{S}$. Paulo. Disponível em <http://www1.folha.uol.com.br/mercado/2015/08/1664711-saiba-o-quesao-as-pautas-bomba-nas-maos-do-congresso-contra-o-governo.shtml> Acesso em 30 jun 2018.

SAIBA quem é Saraiva Felipe, novo ministro da Saúde. Folha de S. Paulo. Disponível em <https://www1.folha.uol.com.br/folha/brasil/ult96u70158.shtml> Acesso em 30 jun 2018.

SARNEY declara apoio à candidatura Lula já no $1^{\circ}$ turno. Portal UOL. Disponível em <https://noticias.uol.com.br/inter/reuters/2002/08/27/ult27u25290.jhtm> Acesso em 30 jun 2018 .

SARNEY diz que Temer é "faccioso" e estimula divisão do PMDB. Folha de S. Paulo. Disponível em <https://www1.folha.uol.com.br/folha/brasil/ult96u66232.shtml> Acesso em 30 jun 2018. 
SEGUNDO pesquisa, $63 \%$ descartam, mas $29 \%$ defendem o impeachment. Folha de S. Paulo. Disponível em <https://www1.folha.uol.com.br/fsp/brasil/fc1208200502.htm> Acesso em 30 jun 2018 .

SENADO aprova impeachment, Dilma perde mandato e Temer assume. Portal G1. Disponível em <http://g1.globo.com/politica/processo-de-impeachment-de-dilma/noticia/2016/08/senadoaprova-impeachment-dilma-perde-mandato-e-temer-assume.html> Acesso em 30 jun 2018.

SENADO aprova MP 664 e derruba fator previdenciário. Portal do Senado. Disponível em $<$ https://www12.senado.leg.br/institucional/presidencia/noticia/renan-calheiros/senadoaprova-mp-664-e-derruba-fator-previdenciario> Acesso em 30 jun 2018.

SENADO aprova MP 665 que altera regras do seguro-desemprego e abono salarial. O Globo. Disponível em <https://oglobo.globo.com/brasil/senado-aprova-mp-665-que-altera-regras-doseguro-desemprego-abono-salarial-16267140> Acesso em 30 jun 2018.

SENADO aprova projeto que impede fusão de partidos recém-criados. Portal G1. Disponível em <http://g1.globo.com/politica/noticia/2015/03/senado-aprova-projeto-que-impede-fusaode-partidos-recem-criados.html> Acesso em 30 jun 2018.

SENADO derruba prorrogação da CPMF. Portal G1. Disponível em <http://g1.globo.com/noticias/economia_negocios/0,,mul215356-9356,00senado+derruba+prorrogacao+da+cpmf.html> Acesso em 30 jun 2018.

SENADO rejeita MP que criava secretaria para Mangabeira Unger. Portal G1. Disponível em <http://g1.globo.com/Noticias/Politica/0,,MUL110817-5601,00.html> Acesso em 30 jun 2018.

SENADO rejeita recondução ao cargo do presidente da ANTT. Portal G1. Disponível em <http://g1.globo.com/politica/noticia/2012/03/senado-rejeita-reconducao-de-bernardofigueiredo-antt.html> Acesso em 30 jun 2018.

TEMER ataca Renan ao anunciar desistência. Folha de S. Paulo. Disponível em <http://www1.folha.uol.com.br/fsp/brasil/fc2909200520.htm> Acesso em 30 jun 2018.

TEMER diz que país precisa de alguém capaz de 'reunificar a todos' na crise. Folha de S. Paulo. Disponível em <http://www1.folha.uol.com.br/poder/2015/08/1664881-temer-faz-apelopublico-por-unidade-e-diz-que-crise-pode-se-agravar.shtml> Acesso em 30 jun 2018.

TEMER é reeleito presidente do PMDB com 598 votos. Folha de S. Paulo. Disponível em <http://www1.folha.uol.com.br/folha/brasil/ult96u90189.shtml> Acesso em 30 jun 2018.

VACCAREZZA era próximo ao PMDB e pertencia a uma ala menos ideológica do PT. Portal Estadão. Disponível em <https://politica.estadao.com.br/noticias/geral,ex-lider-do-governodilma-e-lula-vaccarezza-era-proximo-ao-pmdb-e,70001942014> Acesso em 30 jun 2018.

VERBA sob controle do PMDB deve aumentar 55\%. Folha de S. Paulo. Disponível em <https://www1.folha.uol.com.br/folha/bbc/ult272u61609.shtml> Acesso em 30 jun 2018. 
VICE-GOVERNADOR supera Henrique Alves e vence no RN. Folha de S. Paulo. Disponível em <https://www1.folha.uol.com.br/poder/2014/10/1538707-vice-governador-superahenrique-alves-e-vence-no-rn.shtml> Acesso em 30 jun 2018. 


\section{ANEXO A - CONGRESSO NACIONAL}

Tabela 4. Bancadas dos Partidos - Deputados Federais Eleitos

\begin{tabular}{|c|c|c|c|c|c|c|c|}
\hline \multicolumn{2}{|c|}{2002} & \multicolumn{2}{|c|}{2006} & \multicolumn{2}{|c|}{2010} & \multicolumn{2}{|c|}{2014} \\
\hline PARTIDO & BANCADA & PARTIDO & BANCADA & PARTIDO & BANCADA & PARTIDO & BANCADA \\
\hline PT & 91 & PMDB & 89 & PT & 86 & PT & 68 \\
\hline PFL & 84 & PT & 83 & PMDB & 78 & PMDB & 65 \\
\hline PMDB & 75 & PSDB & 66 & PSDB & 54 & PSDB & 54 \\
\hline PSDB & 70 & PFL & 65 & PP & 44 & PP & 38 \\
\hline PPB & 49 & PP & 41 & DEM & 43 & PSD & 36 \\
\hline PTB & 26 & PSB & 27 & PR & 41 & PSB & 34 \\
\hline $\mathrm{PL}$ & 26 & PDT & 24 & PSB & 35 & PR & 34 \\
\hline PSB & 22 & $\overline{P L}$ & 23 & PDT & 27 & PTB & 25 \\
\hline PDT & 21 & PPS & 22 & PTB & 22 & PRB & 21 \\
\hline PPS & 15 & PTB & 22 & PSC & 17 & DEM & 21 \\
\hline$P C$ do B & 12 & PCdoB & 13 & $P C$ do $B$ & 15 & PDT & 20 \\
\hline PRONA & 6 & PV & 13 & PV & 13 & SD & 15 \\
\hline PV & 5 & PSC & 9 & PPS & 12 & PSC & 13 \\
\hline PSD & 4 & PMN & 3 & PRB & 8 & PROS & 11 \\
\hline PST & 3 & PSOL & 3 & PMN & 4 & PPS & 10 \\
\hline PMN & 1 & PTC & 3 & PSOL & 3 & $P C$ do $B$ & 10 \\
\hline PSC & 1 & PHS & 2 & PT do B & 3 & PV & 8 \\
\hline PSDC & 1 & PRONA & 2 & PHS & 2 & PSOL & 5 \\
\hline PSL & 1 & PAN & 1 & PRTB & 2 & PHS & 5 \\
\hline & & PRB & 1 & PRP & 2 & PTN & 4 \\
\hline & & PTdoB & 1 & PTC & 1 & PRP & 3 \\
\hline & & & & PSL & 1 & PMN & 3 \\
\hline & & & & & & PEN & 2 \\
\hline & & & & & & PSDC & 2 \\
\hline & & & & & & PTC & 2 \\
\hline & & & & & & PT do B & 2 \\
\hline & & & & & & PSL & 1 \\
\hline & & & & & & PRTB & 1 \\
\hline
\end{tabular}

Fonte: Câmara dos Deputados.

Tabela 5. Líderes do Governo e Presidentes das Casas Legislativas

\begin{tabular}{|c|c|c|c|c|c|c|c|c|c|c|c|c|c|c|}
\hline $\begin{array}{l}\text { LÍDERES DO } \\
\text { GOVERNO }\end{array}$ & 2003 & 2004 & 2005 & 2006 & 2007 & 2008 & 2009 & 2010 & 2011 & 2012 & 2013 & 2014 & 2015 & 2016 \\
\hline CÁMARA & $\begin{array}{c}\text { Aldo Rebelo } \\
\text { PCdoB }\end{array}$ & $\begin{array}{l}\text { Professor } \\
\text { Luizinho } \\
\text { PT }\end{array}$ & $\begin{array}{c}\text { Arlindo } \\
\text { Chinaglia } \\
\text { PT }\end{array}$ & $\begin{array}{c}\text { Arlindo } \\
\text { Chinaglia } \\
\text { PT }\end{array}$ & $\begin{array}{c}\text { José Múcio } \\
\text { PTB }\end{array}$ & $\begin{array}{l}\text { Henrique } \\
\text { Fontana } \\
\text { PT }\end{array}$ & $\begin{array}{l}\text { Henrique } \\
\text { Fontana } \\
\text { PT }\end{array}$ & $\begin{array}{c}\text { Cândido } \\
\text { Vaccarezza } \\
\text { PT }\end{array}$ & $\begin{array}{c}\text { Cândido } \\
\text { Vaccarezza } \\
\text { PT }\end{array}$ & $\begin{array}{c}\text { Arlindo } \\
\text { Chinaglia } \\
\text { PT }\end{array}$ & $\begin{array}{c}\text { Arlindo } \\
\text { Chinaglia } \\
\text { PT }\end{array}$ & $\begin{array}{l}\text { Henrique } \\
\text { Fontana } \\
\text { PT }\end{array}$ & $\begin{array}{c}\text { Joséé } \\
\text { Guimarães } \\
\text { PT }\end{array}$ & $\begin{array}{c}\text { José } \\
\text { Guimarães } \\
\text { PT }\end{array}$ \\
\hline SENADO & $\begin{array}{c}\text { Aloizio } \\
\text { Mercadante } \\
\text { PT }\end{array}$ & $\begin{array}{c}\text { Aloizio } \\
\text { Mercadante } \\
\text { PT }\end{array}$ & $\begin{array}{c}\text { Aloizio } \\
\text { Mercadante } \\
\text { PT }\end{array}$ & $\begin{array}{l}\text { Romero } \\
\text { Jucáa } \\
\text { PMDB }\end{array}$ & $\begin{array}{l}\text { Romero } \\
\text { Jucá } \\
\text { PMDB }\end{array}$ & $\begin{array}{c}\text { Romero } \\
\text { Jucá } \\
\text { PMDB }\end{array}$ & $\begin{array}{l}\text { Romero } \\
\text { Jucá } \\
\text { PMDB }\end{array}$ & $\begin{array}{l}\text { Romero } \\
\text { Jucá } \\
\text { PMDB }\end{array}$ & $\begin{array}{l}\text { Romero } \\
\text { Jucá } \\
\text { PMDB }\end{array}$ & $\begin{array}{c}\text { Eduardo } \\
\text { Braga } \\
\text { PMDB }\end{array}$ & $\begin{array}{c}\text { Eduardo } \\
\text { Braga } \\
\text { PMDB }\end{array}$ & $\begin{array}{l}\text { Eduardo } \\
\text { Braga } \\
\text { PMDB }\end{array}$ & $\begin{array}{l}\text { Delcídio } \\
\text { Amaral } \\
\text { PT }\end{array}$ & $\begin{array}{c}\text { Humberto } \\
\text { Costa } \\
\text { PT }\end{array}$ \\
\hline CONGRESSO & $\begin{array}{c}\text { Amir Lando } \\
\text { PMDB }\end{array}$ & $\begin{array}{l}\text { Fernando } \\
\text { Bezerra } \\
\text { PTB } \\
\end{array}$ & $\begin{array}{l}\text { Fernando } \\
\text { Bezerra } \\
\text { PTB } \\
\end{array}$ & $\begin{array}{l}\text { Fernando } \\
\text { Bezerra } \\
\text { PTB } \\
\end{array}$ & $\begin{array}{l}\text { Roseana } \\
\text { Sarney } \\
\text { PMDB }\end{array}$ & $\begin{array}{l}\text { Roseana } \\
\text { Sarney } \\
\text { PMDB } \\
\end{array}$ & $\begin{array}{c}\text { Ideli Salvatti } \\
\text { PT } \\
\end{array}$ & $\begin{array}{c}\text { Ideli Salvatti } \\
\text { PT } \\
\end{array}$ & $\begin{array}{c}\text { José } \\
\text { Pimentel } \\
\text { PT }\end{array}$ & $\begin{array}{c}\text { José } \\
\text { Pimentel } \\
\text { PT }\end{array}$ & $\begin{array}{c}\text { José } \\
\text { Pimentel } \\
\text { PT }\end{array}$ & $\begin{array}{c}\text { José } \\
\text { Pimentel } \\
\text { PT } \\
\end{array}$ & $\begin{array}{c}\text { José } \\
\text { Pimentel } \\
\text { PT }\end{array}$ & $\begin{array}{c}\text { José } \\
\text { Pimentel } \\
\text { PT } \\
\end{array}$ \\
\hline $\begin{array}{l}\text { PRESIDENTES } \\
\text { DAS CASAS }\end{array}$ & 2003 & 2004 & 2005 & 2006 & 2007 & 2008 & 2009 & 2010 & 2011 & 2012 & 2013 & 2014 & 2015 & 2016 \\
\hline CÁMARA & $\begin{array}{c}\text { João Paulo } \\
\text { Cunha } \\
\text { PT }\end{array}$ & $\begin{array}{c}\text { João Paulo } \\
\text { Cunha } \\
\text { PT }\end{array}$ & $\begin{array}{l}\text { Severino } \\
\text { Cavalcanti } \\
\text { PP }\end{array}$ & $\begin{array}{c}\text { Aldo Rebelo } \\
\text { PCdoB }\end{array}$ & $\begin{array}{c}\text { Arlindo } \\
\text { Chinaglia } \\
\text { PT }\end{array}$ & $\begin{array}{c}\text { Arlindo } \\
\text { Chinaglia } \\
\text { PT }\end{array}$ & $\begin{array}{l}\text { Michel } \\
\text { Temer } \\
\text { PMDB }\end{array}$ & $\begin{array}{l}\text { Michel } \\
\text { Temer } \\
\text { PMDB }\end{array}$ & $\begin{array}{c}\text { Marco Maia } \\
\text { PT }\end{array}$ & $\begin{array}{c}\text { Marco Maia } \\
\text { PT }\end{array}$ & $\begin{array}{l}\text { Henrique } \\
\text { Alves } \\
\text { PMDB }\end{array}$ & $\begin{array}{l}\text { Henrique } \\
\text { Alves } \\
\text { PMDB }\end{array}$ & $\begin{array}{l}\text { Eduardo } \\
\text { Cunha } \\
\text { PMDB }\end{array}$ & $\begin{array}{l}\text { Eduardo } \\
\text { Cunha } \\
\text { PMDB }\end{array}$ \\
\hline SENADO & $\begin{array}{c}\text { José Sarney } \\
\text { PMDB }\end{array}$ & $\begin{array}{c}\text { José Sarney } \\
\text { PMDB }\end{array}$ & $\begin{array}{l}\text { Renan } \\
\text { Calheiros } \\
\text { PMDB }\end{array}$ & $\begin{array}{c}\text { Renan } \\
\text { Calheiros } \\
\text { PMDB }\end{array}$ & $\begin{array}{l}\text { Renan } \\
\text { Calheiros } \\
\text { PMDB }\end{array}$ & $\begin{array}{c}\text { Garibaldi } \\
\text { Alves } \\
\text { PMDB }\end{array}$ & $\begin{array}{l}\text { José Sarney } \\
\text { PMDB }\end{array}$ & $\begin{array}{l}\text { José Sarney } \\
\text { PMDB }\end{array}$ & $\begin{array}{c}\text { José Sarney } \\
\text { PMDB }\end{array}$ & $\begin{array}{c}\text { José Sarney } \\
\text { PMDB }\end{array}$ & $\begin{array}{c}\text { Renan } \\
\text { Calheiros } \\
\text { PMDB }\end{array}$ & $\begin{array}{c}\text { Renan } \\
\text { Calheiros } \\
\text { PMDB }\end{array}$ & $\begin{array}{l}\text { Renan } \\
\text { Calheiros } \\
\text { PMDB }\end{array}$ & $\begin{array}{c}\text { Renan } \\
\text { Calheiros } \\
\text { PMDB }\end{array}$ \\
\hline
\end{tabular}




\section{ANEXO B - MINISTÉRIOS}

Tabela 6. Composição dos Ministérios

\begin{tabular}{|c|c|c|c|c|c|c|c|c|}
\hline GOVERNO LULA I & 2003 & & 2004 & & 200 & & 2006 & \\
\hline PASTA & MINISTRO & PARTIDO & MINISTRO & PARTIDO & MINISTRO & PARTIDO & MINISTRO & PARTIDO \\
\hline $\begin{array}{c}\text { Advocacia Geral da } \\
\text { União }\end{array}$ & $\begin{array}{l}\text { Álvaro Augusto } \\
\text { Ribeiro Costa }\end{array}$ & $\begin{array}{c}\text { Sem } \\
\text { partido }\end{array}$ & $\begin{array}{l}\text { Álvaro Augusto } \\
\text { Ribeiro Costa }\end{array}$ & $\begin{array}{c}\text { Sem } \\
\text { partido }\end{array}$ & $\begin{array}{c}\text { Álvaro Augusto } \\
\text { Ribeiro Costa }\end{array}$ & $\begin{array}{c}\text { Sem } \\
\text { partido }\end{array}$ & $\begin{array}{c}\text { Álvaro Augusto } \\
\text { Ribeiro Costa }\end{array}$ & $\begin{array}{c}\text { Sem } \\
\text { partido }\end{array}$ \\
\hline $\begin{array}{c}\text { Agricultura, } \\
\text { Pecuária e } \\
\text { Abastecimento }\end{array}$ & $\begin{array}{c}\text { Roberto } \\
\text { Rodrigues }\end{array}$ & $\begin{array}{c}\text { Sem } \\
\text { partido }\end{array}$ & $\begin{array}{l}\text { Roberto } \\
\text { Rodrigues }\end{array}$ & $\begin{array}{c}\text { Sem } \\
\text { partido }\end{array}$ & $\begin{array}{l}\text { Roberto } \\
\text { Rodrigues }\end{array}$ & $\begin{array}{c}\text { Sem } \\
\text { partido }\end{array}$ & $\begin{array}{l}\text { Luís Carlos } \\
\text { Guedes Pinto }\end{array}$ & PT \\
\hline $\begin{array}{c}\text { Banco Central do } \\
\text { Brasil }\end{array}$ & $\begin{array}{l}\text { Henrique } \\
\text { Meirelles }\end{array}$ & $\begin{array}{c}\text { Sem } \\
\text { partido }\end{array}$ & $\begin{array}{l}\text { Henrique } \\
\text { Meirelles }\end{array}$ & $\begin{array}{c}\text { Sem } \\
\text { partido }\end{array}$ & $\begin{array}{l}\text { Henrique } \\
\text { Meirelles }\end{array}$ & $\begin{array}{c}\text { Sem } \\
\text { partido }\end{array}$ & $\begin{array}{l}\text { Henrique } \\
\text { Meirelles }\end{array}$ & $\begin{array}{c}\text { Sem } \\
\text { partido }\end{array}$ \\
\hline Casa Civil & José Dirceu & $\mathrm{PT}$ & José Dirceu & PT & Dilma Rousseff & PT & Dilma Rousseff & $\mathrm{PT}$ \\
\hline Cidades & Olívio Dutra & PT & Olívio Dutra & PT & Márcio Fortes & PP & Márcio Fortes & PP \\
\hline $\begin{array}{c}\text { Ciência, Tecnologia } \\
\text { e Inovações }\end{array}$ & Roberto Amaral & PSB & $\begin{array}{l}\text { Eduardo } \\
\text { Campos }\end{array}$ & PSB & $\begin{array}{c}\text { Sérgio } \\
\text { Rezende }\end{array}$ & PSB & Sérgio Rezende & PSB \\
\hline Comunicações & Miro Teixeira & PDT & Eunício Oliveira & PMDB & Hélio Costa & PMDB & Hélio Costa & PMDB \\
\hline $\begin{array}{c}\text { Controladoria Geral } \\
\text { da União }\end{array}$ & Waldir Pires & PT & Waldir Pires & PT & Waldir Pires & PT & Jorge Hage & PT \\
\hline Cultura & Gilberto Gil & $\begin{array}{c}\text { Sem } \\
\text { partido }\end{array}$ & Gilberto Gil & $\begin{array}{c}\text { Sem } \\
\text { partido }\end{array}$ & Gilberto Gil & $\begin{array}{c}\text { Sem } \\
\text { partido }\end{array}$ & Gilberto Gil & $\begin{array}{c}\text { Sem } \\
\text { partido }\end{array}$ \\
\hline Defesa & José Viegas & $\begin{array}{c}\text { Sem } \\
\text { partido }\end{array}$ & José Viegas & $\begin{array}{c}\text { Sem } \\
\text { partido }\end{array}$ & José Alencar & PL & Waldir Pires & PT \\
\hline $\begin{array}{c}\text { Desenvolvimento } \\
\text { Agrário }\end{array}$ & $\begin{array}{c}\text { Miguel } \\
\text { Rossetto }\end{array}$ & PT & Miguel Rossetto & PT & $\begin{array}{c}\text { Miguel } \\
\text { Rossetto }\end{array}$ & PT & Guilherme Cassel & PT \\
\hline $\begin{array}{c}\text { Desenvolvimento } \\
\text { Social }\end{array}$ & $\begin{array}{l}\text { Benedita da } \\
\text { Silva }\end{array}$ & PT & Patrus Ananias & PT & Patrus Ananias & PT & Patrus Ananias & PT \\
\hline $\begin{array}{l}\text { Desenvolvimento, } \\
\text { Indústria e } \\
\text { Comércio }\end{array}$ & $\begin{array}{l}\text { Luiz Fernando } \\
\text { Furlan }\end{array}$ & $\begin{array}{c}\text { Sem } \\
\text { partido }\end{array}$ & $\begin{array}{l}\text { Luiz Fernando } \\
\text { Furlan }\end{array}$ & $\begin{array}{c}\text { Sem } \\
\text { partido }\end{array}$ & $\begin{array}{l}\text { Luiz Fernando } \\
\text { Furlan }\end{array}$ & $\begin{array}{c}\text { Sem } \\
\text { partido }\end{array}$ & $\begin{array}{l}\text { Luiz Fernando } \\
\text { Furlan }\end{array}$ & $\begin{array}{c}\text { Sem } \\
\text { partido }\end{array}$ \\
\hline Educação & $\begin{array}{l}\text { Cristóvam } \\
\text { Buarque }\end{array}$ & PT & Tarso Genro & PT & $\begin{array}{c}\text { Fernando } \\
\text { Haddad }\end{array}$ & PT & Fernando Haddad & PT \\
\hline Esporte & Agnelo Queiroz & PCdoB & Agnelo Queiroz & PCdoB & Agnelo Queiroz & PCdoB & Orlando Silva & PCdoB \\
\hline Fazenda & Antonio Palocci & $\mathrm{PT}$ & Antonio Palocci & PT & Antonio Palocci & $\mathrm{PT}$ & Guido Mantega & $\mathrm{PT}$ \\
\hline $\begin{array}{l}\text { Gabinete de } \\
\text { Segurança } \\
\text { Institucional }\end{array}$ & Jorge Félix & $\begin{array}{c}\text { Sem } \\
\text { partido }\end{array}$ & Jorge Félix & $\begin{array}{c}\text { Sem } \\
\text { partido }\end{array}$ & Jorge Félix & $\begin{array}{c}\text { Sem } \\
\text { partido }\end{array}$ & Jorge Félix & $\begin{array}{c}\text { Sem } \\
\text { partido }\end{array}$ \\
\hline Integração Nacional & Ciro Gomes & PPS & Ciro Gomes & PPS & Ciro Gomes & PSB & Pedro Brito & PSB \\
\hline Justiça & $\begin{array}{c}\text { Márcio Thomaz } \\
\text { Bastos }\end{array}$ & $\begin{array}{c}\text { Sem } \\
\text { partido }\end{array}$ & $\begin{array}{c}\text { Márcio Thomaz } \\
\text { Bastos }\end{array}$ & $\begin{array}{c}\text { Sem } \\
\text { partido }\end{array}$ & $\begin{array}{c}\text { Márcio Thomaz } \\
\text { Bastos }\end{array}$ & $\begin{array}{c}\text { Sem } \\
\text { partido }\end{array}$ & $\begin{array}{c}\text { Márcio Thomaz } \\
\text { Bastos }\end{array}$ & $\begin{array}{c}\text { Sem } \\
\text { partido }\end{array}$ \\
\hline Meio Ambiente & Marina Silva & PT & Marina Silva & PT & Marina Silva & PT & Marina Silva & $\mathrm{PT}$ \\
\hline Minas e Energia & Dilma Rousseff & PT & Dilma Rousseff & PT & Silas Rondeau & PMDB & Silas Rondeau & PMDB \\
\hline Pesca e Aquicultura & José Fritsch & PT & José Fritsch & PT & José Fritsch & PT & Altemir Gregolin & PT \\
\hline $\begin{array}{l}\text { Planejamento, } \\
\text { Orçamento e } \\
\text { Gestão }\end{array}$ & Guido Mantega & PT & Guido Mantega & PT & Paulo Bernardo & PT & Paulo Bernardo & PT \\
\hline Previdência Social & $\begin{array}{l}\text { Ricardo } \\
\text { Berzoini }\end{array}$ & PT & Amir Lando & PMDB & Romero Jucá & PMDB & Nelson Machado & PT \\
\hline Relações Exteriores & Celso Amorim & $\begin{array}{c}\text { Sem } \\
\text { partido }\end{array}$ & Celso Amorim & $\begin{array}{c}\text { Sem } \\
\text { partido }\end{array}$ & Celso Amorim & $\begin{array}{c}\text { Sem } \\
\text { partido }\end{array}$ & Celso Amorim & $\begin{array}{c}\text { Sem } \\
\text { partido }\end{array}$ \\
\hline Saúde & $\begin{array}{c}\text { Humberto } \\
\text { Costa }\end{array}$ & PT & Humberto Costa & PT & Saraiva Felipe & PMDB & Agenor Álvares & PMDB \\
\hline
\end{tabular}




\begin{tabular}{|c|c|c|c|c|c|c|c|c|}
\hline $\begin{array}{c}\text { Secretaria de } \\
\text { Comunicação } \\
\text { Social }\end{array}$ & Luiz Gushiken & PT & Luiz Gushiken & PT & Luiz Gushiken & PT & Luiz Tadeu Rigo & PT \\
\hline $\begin{array}{c}\text { Secretaria de } \\
\text { Direitos Humanos }\end{array}$ & $\begin{array}{l}\text { Nilmário } \\
\text { Miranda }\end{array}$ & PT & Nilmário Miranda & PT & $\begin{array}{l}\text { Nilmário } \\
\text { Miranda }\end{array}$ & PT & Paulo Vannuchi & PT \\
\hline $\begin{array}{c}\text { Secretaria de } \\
\text { Igualdade Racial }\end{array}$ & Matilde Ribeiro & PT & Matilde Ribeiro & PT & Matilde Ribeiro & PT & Matilde Ribeiro & PT \\
\hline $\begin{array}{c}\text { Secretaria de } \\
\text { Políticas para as } \\
\text { Mulheres }\end{array}$ & $\begin{array}{c}\text { Emília } \\
\text { Fernandes }\end{array}$ & PT & Nilceia Freire & PT & Nilceia Freire & PT & Nilceia Freire & PT \\
\hline $\begin{array}{c}\text { Secretaria de } \\
\text { Relações } \\
\text { Institucionais }\end{array}$ & - & - & Aldo Rebelo & PCdoB & Jaques Wagner & PT & Tarso Genro & PT \\
\hline Secretaria Geral & Luiz Dulci & PT & Luiz Dulci & PT & Luiz Dulci & PT & Luiz Dulci & PT \\
\hline $\begin{array}{l}\text { Trabalho e } \\
\text { Emprego }\end{array}$ & Jaques Wagner & PT & Ricardo Berzoini & PT & Luiz Marinho & PT & Luiz Marinho & PT \\
\hline Transportes & $\begin{array}{c}\text { Anderson } \\
\text { Adauto }\end{array}$ & $\mathrm{PL}$ & $\begin{array}{c}\text { Alfredo } \\
\text { Nascimento }\end{array}$ & PL & $\begin{array}{c}\text { Alfredo } \\
\text { Nascimento }\end{array}$ & PL & Paulo Passos & PL \\
\hline Turismo & $\begin{array}{c}\text { Walfrido Mares } \\
\text { Guia }\end{array}$ & PTB & $\begin{array}{c}\text { Walfrido Mares } \\
\text { Guia }\end{array}$ & PTB & $\begin{array}{c}\text { Walfrido Mares } \\
\text { Guia }\end{array}$ & PTB & $\begin{array}{l}\text { Walfrido Mares } \\
\text { Guia }\end{array}$ & PTB \\
\hline
\end{tabular}

\begin{tabular}{|c|c|c|c|c|c|c|c|c|}
\hline \multirow{2}{*}{$\begin{array}{c}\begin{array}{c}\text { GOVERNO LULA II } \\
(2007-2010)\end{array} \\
\text { PASTA }\end{array}$} & \multicolumn{2}{|c|}{2007} & \multicolumn{2}{|c|}{2008} & \multicolumn{2}{|c|}{2009} & \multicolumn{2}{|l|}{2010} \\
\hline & MINISTRO & PARTIDO & MINISTRO & PARTIDO & MINISTRO & PARTIDO & MINISTRO & PARTIDO \\
\hline $\begin{array}{c}\text { Advocacia Geral da } \\
\text { União }\end{array}$ & $\begin{array}{c}\text { José Antonio } \\
\text { Dias Toffoli }\end{array}$ & $\begin{array}{l}\text { Sem } \\
\text { partido }\end{array}$ & $\begin{array}{l}\text { José Antonio } \\
\text { Dias Toffoli }\end{array}$ & $\begin{array}{l}\text { Sem } \\
\text { partido }\end{array}$ & $\begin{array}{l}\text { José Antonio } \\
\text { Dias Toffoli }\end{array}$ & $\begin{array}{c}\text { Sem } \\
\text { partido }\end{array}$ & $\begin{array}{c}\text { Luís Inácio } \\
\text { Lucena Adams }\end{array}$ & $\begin{array}{l}\text { Sem } \\
\text { partido }\end{array}$ \\
\hline $\begin{array}{c}\text { Agricultura, } \\
\text { Pecuária e } \\
\text { Abastecimento }\end{array}$ & $\begin{array}{l}\text { Reinhold } \\
\text { Stephanes }\end{array}$ & PMDB & $\begin{array}{l}\text { Reinhold } \\
\text { Stephanes }\end{array}$ & PMDB & $\begin{array}{l}\text { Reinhold } \\
\text { Stephanes }\end{array}$ & PMDB & Wagner Rossi & PMDB \\
\hline $\begin{array}{c}\text { Banco Central do } \\
\text { Brasil }\end{array}$ & $\begin{array}{l}\text { Henrique } \\
\text { Meirelles }\end{array}$ & $\begin{array}{l}\text { Sem } \\
\text { partido }\end{array}$ & $\begin{array}{l}\text { Henrique } \\
\text { Meirelles }\end{array}$ & $\begin{array}{l}\text { Sem } \\
\text { partido }\end{array}$ & $\begin{array}{l}\text { Henrique } \\
\text { Meirelles }\end{array}$ & $\begin{array}{l}\text { Sem } \\
\text { partido }\end{array}$ & $\begin{array}{l}\text { Henrique } \\
\text { Meirelles }\end{array}$ & $\begin{array}{l}\text { Sem } \\
\text { partido }\end{array}$ \\
\hline Casa Civil & Dilma Rousseff & PT & Dilma Rousseff & PT & Dilma Rousseff & PT & Erenice Guerra & PT \\
\hline Cidades & Márcio Fortes & $\mathrm{PP}$ & Márcio Fortes & $\mathrm{PP}$ & Márcio Fortes & $\mathrm{PP}$ & Márcio Fortes & $\mathrm{PP}$ \\
\hline $\begin{array}{c}\text { Ciência, Tecnologia } \\
\text { e Inovações }\end{array}$ & $\begin{array}{c}\text { Sérgio } \\
\text { Rezende }\end{array}$ & PSB & Sérgio Rezende & PSB & $\begin{array}{l}\text { Sérgio } \\
\text { Rezende }\end{array}$ & PSB & Sérgio Rezende & PSB \\
\hline Comunicações & Hélio Costa & PMDB & Hélio Costa & PMDB & Hélio Costa & PMDB & José Artur Filardi & PMDB \\
\hline $\begin{array}{l}\text { Controladoria Geral } \\
\text { da União }\end{array}$ & Jorge Hage & PT & Jorge Hage & PT & Jorge Hage & PT & Jorge Hage & PT \\
\hline Cultura & Gilberto Gil & $\begin{array}{l}\text { Sem } \\
\text { partido }\end{array}$ & Juca Ferreira & PT & Juca Ferreira & PT & Juca Ferreira & PT \\
\hline Defesa & Nelson Jobim & PMDB & Nelson Jobim & PMDB & Nelson Jobim & PMDB & Nelson Jobim & PMDB \\
\hline $\begin{array}{c}\text { Desenvolvimento } \\
\text { Agrário }\end{array}$ & $\begin{array}{l}\text { Guilherme } \\
\text { Cassel }\end{array}$ & PT & $\begin{array}{l}\text { Guilherme } \\
\text { Cassel }\end{array}$ & PT & $\begin{array}{c}\text { Guilherme } \\
\text { Cassel }\end{array}$ & PT & Guilherme Cassel & PT \\
\hline $\begin{array}{c}\text { Desenvolvimento } \\
\text { Social }\end{array}$ & Patrus Ananias & PT & Patrus Ananias & PT & Patrus Ananias & PT & Márcia Lopes & PT \\
\hline $\begin{array}{l}\text { Desenvolvimento, } \\
\text { Indústria e } \\
\text { Comércio }\end{array}$ & Miguel Jorge & $\begin{array}{l}\text { Sem } \\
\text { partido }\end{array}$ & Miguel Jorge & $\begin{array}{l}\text { Sem } \\
\text { partido }\end{array}$ & Miguel Jorge & $\begin{array}{l}\text { Sem } \\
\text { partido }\end{array}$ & Miguel Jorge & $\begin{array}{l}\text { Sem } \\
\text { partido }\end{array}$ \\
\hline Educação & $\begin{array}{c}\text { Fernando } \\
\text { Haddad }\end{array}$ & PT & $\begin{array}{l}\text { Fernando } \\
\text { Haddad }\end{array}$ & PT & $\begin{array}{l}\text { Fernando } \\
\text { Haddad }\end{array}$ & PT & Fernando Haddad & PT \\
\hline Esporte & Orlando Silva & PCdoB & Orlando Silva & PCdoB & Orlando Silva & PCdoB & Orlando Silva & PCdoB \\
\hline Fazenda & Guido Mantega & PT & Guido Mantega & PT & Guido Mantega & PT & Guido Mantega & PT \\
\hline
\end{tabular}




\begin{tabular}{|c|c|c|c|c|c|c|c|c|}
\hline $\begin{array}{l}\text { Gabinete de } \\
\text { Segurança } \\
\text { Institucional }\end{array}$ & Jorge Félix & $\begin{array}{l}\text { Sem } \\
\text { partido }\end{array}$ & Jorge Félix & $\begin{array}{l}\text { Sem } \\
\text { partido }\end{array}$ & Jorge Félix & $\begin{array}{l}\text { Sem } \\
\text { partido }\end{array}$ & Jorge Félix & $\begin{array}{c}\text { Sem } \\
\text { partido }\end{array}$ \\
\hline Integração Nacional & $\begin{array}{c}\text { Geddel Vieira } \\
\text { Lima }\end{array}$ & PMDB & $\begin{array}{l}\text { Geddel Vieira } \\
\text { Lima }\end{array}$ & PMDB & $\begin{array}{c}\text { Geddel Vieira } \\
\text { Lima }\end{array}$ & PMDB & João Santana & PMDB \\
\hline Justiça & Tarso Genro & PT & Tarso Genro & PT & Tarso Genro & PT & $\begin{array}{c}\text { Luiz Paulo } \\
\text { Barreto }\end{array}$ & $\begin{array}{c}\text { Sem } \\
\text { partido }\end{array}$ \\
\hline Meio Ambiente & Marina Silva & PT & Carlos Minc & PT & Carlos Minc & PT & Izabella Teixeira & $\begin{array}{c}\text { Sem } \\
\text { partido }\end{array}$ \\
\hline Minas e Energia & Silas Rondeau & PMDB & Edison Lobão & PMDB & Edison Lobão & PMDB & $\begin{array}{c}\text { Márcio } \\
\text { Zimmermann }\end{array}$ & PMDB \\
\hline Pesca e Aquicultura & $\begin{array}{l}\text { Altemir } \\
\text { Gregolin }\end{array}$ & PT & Altemir Gregolin & PT & $\begin{array}{l}\text { Altemir } \\
\text { Gregolin }\end{array}$ & PT & Altemir Gregolin & PT \\
\hline $\begin{array}{c}\text { Planejamento, } \\
\text { Orçamento e } \\
\text { Gestão }\end{array}$ & Paulo Bernardo & PT & Paulo Bernardo & PT & Paulo Bernardo & PT & Paulo Bernardo & PT \\
\hline Portos & Pedro Brito & PSB & Pedro Brito & PSB & Pedro Brito & PSB & Pedro Brito & PSB \\
\hline Previdência Social & Luiz Marinho & PT & José Pimentel & PT & José Pimentel & PT & Carlos Gabas & PT \\
\hline Relações Exteriores & Celso Amorim & $\begin{array}{c}\text { Sem } \\
\text { partido }\end{array}$ & Celso Amorim & $\begin{array}{c}\text { Sem } \\
\text { partido }\end{array}$ & Celso Amorim & $\begin{array}{c}\text { Sem } \\
\text { partido }\end{array}$ & Celso Amorim & $\begin{array}{c}\text { Sem } \\
\text { partido }\end{array}$ \\
\hline Saúde & $\begin{array}{l}\text { José Gomes } \\
\text { Temporão }\end{array}$ & PMDB & $\begin{array}{l}\text { José Gomes } \\
\text { Temporão }\end{array}$ & PMDB & $\begin{array}{l}\text { José Gomes } \\
\text { Temporão }\end{array}$ & PMDB & $\begin{array}{l}\text { José Gomes } \\
\text { Temporão }\end{array}$ & PMDB \\
\hline $\begin{array}{l}\text { Secretaria de } \\
\text { Assuntos } \\
\text { Estratégicos }\end{array}$ & $\begin{array}{c}\text { Roberto } \\
\text { Mangabeira } \\
\text { Unger }\end{array}$ & PRB & $\begin{array}{l}\text { Roberto } \\
\text { Mangabeira } \\
\text { Unger }\end{array}$ & PRB & $\begin{array}{c}\text { Roberto } \\
\text { Mangabeira } \\
\text { Unger }\end{array}$ & PRB & $\begin{array}{l}\text { Samuel Pinheiro } \\
\text { Guimarães }\end{array}$ & PT \\
\hline $\begin{array}{c}\text { Secretaria de } \\
\text { Comunicação } \\
\text { Social }\end{array}$ & $\begin{array}{l}\text { Franklin } \\
\text { Martins }\end{array}$ & $\begin{array}{l}\text { Sem } \\
\text { partido }\end{array}$ & Franklin Martins & $\begin{array}{l}\text { Sem } \\
\text { partido }\end{array}$ & $\begin{array}{l}\text { Franklin } \\
\text { Martins }\end{array}$ & $\begin{array}{l}\text { Sem } \\
\text { partido }\end{array}$ & Franklin Martins & $\begin{array}{l}\text { Sem } \\
\text { partido }\end{array}$ \\
\hline $\begin{array}{c}\text { Secretaria de } \\
\text { Direitos Humanos }\end{array}$ & Paulo Vannuchi & PT & Paulo Vannuchi & PT & Paulo Vannuchi & PT & Paulo Vannuchi & PT \\
\hline $\begin{array}{c}\text { Secretaria de } \\
\text { Igualdade Racial }\end{array}$ & Matilde Ribeiro & PT & Edson Santos & PT & Edson Santos & PT & Eloi Araujo & PT \\
\hline $\begin{array}{c}\text { Secretaria de } \\
\text { Políticas para as } \\
\text { Mulheres }\end{array}$ & Nilceia Freire & PT & Nilceia Freire & PT & Nilceia Freire & PT & Nilceia Freire & PT \\
\hline $\begin{array}{l}\text { Secretaria de } \\
\text { Relações } \\
\text { Institucionais }\end{array}$ & $\begin{array}{c}\text { Walfrido Mares } \\
\text { Guia }\end{array}$ & PTB & José Múcio & PTB & José Múcio & PTB & $\begin{array}{l}\text { Alexandre } \\
\text { Padilha }\end{array}$ & PT \\
\hline Secretaria Geral & Luiz Dulci & PT & Luiz Dulci & PT & Luiz Dulci & PT & Luiz Dulci & PT \\
\hline $\begin{array}{l}\text { Trabalho e } \\
\text { Emprego }\end{array}$ & Carlos Lupi & PDT & Carlos Lupi & PDT & Carlos Lupi & PDT & Carlos Lupi & PDT \\
\hline Transportes & $\begin{array}{c}\text { Alfredo } \\
\text { Nascimento }\end{array}$ & PR & $\begin{array}{c}\text { Alfredo } \\
\text { Nascimento }\end{array}$ & PR & $\begin{array}{c}\text { Alfredo } \\
\text { Nascimento }\end{array}$ & PR & Paulo Passos & PR \\
\hline Turismo & Marta Suplicy & PT & Luiz Barreto & PT & Luiz Barreto & PT & Luiz Barreto & PT \\
\hline
\end{tabular}

\begin{tabular}{|c|c|c|c|c|c|c|c|c|}
\hline $\begin{array}{c}\text { GOVERNO DILMA I } \\
\text { (2011-2014) }\end{array}$ & \multicolumn{2}{|c|}{2011} & \multicolumn{2}{c|}{2012} & \multicolumn{2}{c|}{2013} & \multicolumn{2}{c|}{2014} \\
\hline PASTA & MINISTRO & PARTIDO & MINISTRO & PARTIDO & MINISTRO & PARTIDO & MINISTRO & PARTIDO \\
\hline $\begin{array}{c}\text { Advocacia Geral da } \\
\text { União }\end{array}$ & $\begin{array}{c}\text { Luís Inácio } \\
\text { Lucena Adams }\end{array}$ & $\begin{array}{c}\text { Sem } \\
\text { partido }\end{array}$ & $\begin{array}{c}\text { Luís Inácio } \\
\text { Lucena Adams }\end{array}$ & $\begin{array}{c}\text { Sem } \\
\text { partido }\end{array}$ & $\begin{array}{c}\text { Luís Inácio } \\
\text { Lucena Adams }\end{array}$ & $\begin{array}{c}\text { Sem } \\
\text { partido }\end{array}$ & $\begin{array}{c}\text { Luís Inácio } \\
\text { Lucena Adams }\end{array}$ & $\begin{array}{c}\text { Sem } \\
\text { partido }\end{array}$ \\
\hline $\begin{array}{c}\text { Agricultura, } \\
\text { Pecuária e } \\
\text { Abastecimento }\end{array}$ & Wagner Rossi & PMDB & Mendes Ribeiro & PMDB & $\begin{array}{c}\text { Antonio } \\
\text { Andrade }\end{array}$ & PMDB & Neri Geller & PMDB \\
\hline $\begin{array}{c}\text { Banco Central do } \\
\text { Brasil }\end{array}$ & $\begin{array}{c}\text { Alexandre } \\
\text { Tombini }\end{array}$ & $\begin{array}{c}\text { Sem } \\
\text { partido }\end{array}$ & $\begin{array}{c}\text { Alexandre } \\
\text { Tombini }\end{array}$ & $\begin{array}{c}\text { Sem } \\
\text { partido }\end{array}$ & $\begin{array}{c}\text { Alexandre } \\
\text { Tombini }\end{array}$ & $\begin{array}{c}\text { Sem } \\
\text { partido }\end{array}$ & $\begin{array}{c}\text { Alexandre } \\
\text { Tombini }\end{array}$ & $\begin{array}{c}\text { Sem } \\
\text { partido }\end{array}$ \\
\hline
\end{tabular}




\begin{tabular}{|c|c|c|c|c|c|c|c|c|}
\hline Casa Civil & Antonio Palocci & PT & Gleisi Hoffmann & PT & $\begin{array}{l}\text { Gleisi } \\
\text { Hoffmann }\end{array}$ & PT & $\begin{array}{c}\text { Aloizio } \\
\text { Mercadante }\end{array}$ & PT \\
\hline Cidades & $\begin{array}{c}\text { Mário } \\
\text { Negromonte }\end{array}$ & PP & $\begin{array}{l}\text { Aguinaldo } \\
\text { Ribeiro }\end{array}$ & PP & $\begin{array}{l}\text { Aguinaldo } \\
\text { Ribeiro }\end{array}$ & PP & Gilberto Occhi & PP \\
\hline $\begin{array}{l}\text { Ciência, Tecnologia } \\
\text { e Inovações }\end{array}$ & $\begin{array}{c}\text { Aloizio } \\
\text { Mercadante }\end{array}$ & PT & $\begin{array}{l}\text { Marco Antonio } \\
\text { Raupp }\end{array}$ & $\begin{array}{l}\text { Sem } \\
\text { partido }\end{array}$ & $\begin{array}{l}\text { Marco Antonio } \\
\text { Raupp }\end{array}$ & $\begin{array}{c}\text { Sem } \\
\text { partido }\end{array}$ & $\begin{array}{l}\text { Clelio Campolina } \\
\text { Diniz }\end{array}$ & $\begin{array}{l}\text { Sem } \\
\text { partido }\end{array}$ \\
\hline Comunicações & Paulo Bernardo & PT & Paulo Bernardo & PT & Paulo Bernardo & PT & Paulo Bernardo & PT \\
\hline $\begin{array}{c}\text { Controladoria Geral } \\
\text { da União }\end{array}$ & Jorge Hage & PT & Jorge Hage & PT & Jorge Hage & PT & Jorge Hage & PT \\
\hline Cultura & $\begin{array}{c}\text { Ana de } \\
\text { Hollanda }\end{array}$ & $\begin{array}{c}\text { Sem } \\
\text { partido }\end{array}$ & Ana de Hollanda & $\begin{array}{c}\text { Sem } \\
\text { partido }\end{array}$ & Marta Suplicy & PT & Marta Suplicy & PT \\
\hline Defesa & Nelson Jobim & PMDB & Celso Amorim & PT & Celso Amorim & PT & Celso Amorim & PT \\
\hline $\begin{array}{c}\text { Desenvolvimento } \\
\text { Agrário }\end{array}$ & $\begin{array}{c}\text { Afonso } \\
\text { Florence }\end{array}$ & PT & Pepe Vargas & PT & Pepe Vargas & PT & Miguel Rossetto & PT \\
\hline $\begin{array}{c}\text { Desenvolvimento } \\
\text { Social }\end{array}$ & $\begin{array}{c}\text { Tereza } \\
\text { Campelo }\end{array}$ & PT & Tereza Campelo & PT & $\begin{array}{c}\text { Tereza } \\
\text { Campelo }\end{array}$ & PT & Tereza Campelo & PT \\
\hline $\begin{array}{l}\text { Desenvolvimento, } \\
\text { Indústria e } \\
\text { Comércio }\end{array}$ & $\begin{array}{l}\text { Fernando } \\
\text { Pimentel }\end{array}$ & PT & $\begin{array}{l}\text { Fernando } \\
\text { Pimentel }\end{array}$ & PT & $\begin{array}{l}\text { Fernando } \\
\text { Pimentel }\end{array}$ & PT & Mauro Borges & $\begin{array}{l}\text { Sem } \\
\text { partido }\end{array}$ \\
\hline Educação & $\begin{array}{c}\text { Fernando } \\
\text { Haddad }\end{array}$ & PT & $\begin{array}{c}\text { Aloizio } \\
\text { Mercadante }\end{array}$ & PT & $\begin{array}{c}\text { Aloizio } \\
\text { Mercadante }\end{array}$ & PT & $\begin{array}{l}\text { Jose Henrique } \\
\text { Paim }\end{array}$ & PT \\
\hline Esporte & Orlando Silva & PCdoB & Aldo Rebelo & PCdoB & Aldo Rebelo & PCdoB & Aldo Rebelo & PCdoB \\
\hline Fazenda & Guido Mantega & PT & Guido Mantega & PT & Guido Mantega & PT & Guido Mantega & PT \\
\hline $\begin{array}{l}\text { Gabinete de } \\
\text { Segurança } \\
\text { Institucional }\end{array}$ & $\begin{array}{l}\text { José Elito } \\
\text { Siqueira }\end{array}$ & $\begin{array}{l}\text { Sem } \\
\text { partido }\end{array}$ & $\begin{array}{l}\text { José Elito } \\
\text { Siqueira }\end{array}$ & $\begin{array}{l}\text { Sem } \\
\text { partido }\end{array}$ & $\begin{array}{l}\text { José Elito } \\
\text { Siqueira }\end{array}$ & $\begin{array}{l}\text { Sem } \\
\text { partido }\end{array}$ & $\begin{array}{l}\text { José Elito } \\
\text { Siqueira }\end{array}$ & $\begin{array}{l}\text { Sem } \\
\text { partido }\end{array}$ \\
\hline Integração Nacional & \begin{tabular}{|c|} 
Fernando \\
Bezerra Coelho
\end{tabular} & PSB & $\begin{array}{c}\text { Fernando } \\
\text { Bezerra Coelho }\end{array}$ & PSB & $\begin{array}{c}\text { Fernando } \\
\text { Bezerra Coelho }\end{array}$ & PSB & $\begin{array}{c}\text { Francisco } \\
\text { Teixeira }\end{array}$ & PROS \\
\hline Justiça & $\begin{array}{l}\text { José Eduardo } \\
\text { Cardozo }\end{array}$ & PT & $\begin{array}{l}\text { José Eduardo } \\
\text { Cardozo }\end{array}$ & PT & $\begin{array}{l}\text { José Eduardo } \\
\text { Cardozo }\end{array}$ & PT & $\begin{array}{l}\text { José Eduardo } \\
\text { Cardozo }\end{array}$ & PT \\
\hline Meio Ambiente & $\begin{array}{l}\text { Izabella } \\
\text { Teixeira }\end{array}$ & $\begin{array}{c}\text { Sem } \\
\text { partido }\end{array}$ & Izabella Teixeira & $\begin{array}{c}\text { Sem } \\
\text { partido }\end{array}$ & $\begin{array}{l}\text { Izabella } \\
\text { Teixeira }\end{array}$ & $\begin{array}{c}\text { Sem } \\
\text { partido }\end{array}$ & Izabella Teixeira & $\begin{array}{r}\text { Sem } \\
\text { partido }\end{array}$ \\
\hline Minas e Energia & Edison Lobão & PMDB & Edison Lobão & PMDB & Edison Lobão & PMDB & Edison Lobão & PMDB \\
\hline Pesca e Aquicultura & Ideli Salvatti & PT & Marcelo Crivela & PRB & Marcelo Crivela & PRB & Eduardo Lopes & PRB \\
\hline $\begin{array}{c}\text { Planejamento, } \\
\text { Orçamento e } \\
\text { Gestão }\end{array}$ & Miriam Belchior & PT & Miriam Belchior & PT & Miriam Belchior & PT & Miriam Belchior & PT \\
\hline Portos & $\begin{array}{l}\text { Leônidas } \\
\text { Cristino }\end{array}$ & PSB & Leônidas Cristino & PSB & $\begin{array}{l}\text { Leônidas } \\
\text { Cristino }\end{array}$ & PSB & César Borges & PR \\
\hline Previdência Social & Garibaldi Alves & PMDB & Garibaldi Alves & PMDB & Garibaldi Alves & PMDB & Garibaldi Alves & PMDB \\
\hline Relações Exteriores & $\begin{array}{l}\text { Antonio } \\
\text { Patriota }\end{array}$ & $\begin{array}{c}\text { Sem } \\
\text { partido }\end{array}$ & Antonio Patriota & $\begin{array}{c}\text { Sem } \\
\text { partido }\end{array}$ & $\begin{array}{l}\text { Antonio } \\
\text { Patriota }\end{array}$ & $\begin{array}{c}\text { Sem } \\
\text { partido }\end{array}$ & $\begin{array}{l}\text { Luiz Alberto } \\
\text { Figueiredo }\end{array}$ & $\begin{array}{l}\text { Sem } \\
\text { partido }\end{array}$ \\
\hline Saúde & $\begin{array}{l}\text { Alexandre } \\
\text { Padilha }\end{array}$ & PT & $\begin{array}{l}\text { Alexandre } \\
\text { Padilha }\end{array}$ & PT & $\begin{array}{l}\text { Alexandre } \\
\text { Padilha }\end{array}$ & PT & Arthur Chioro & PT \\
\hline $\begin{array}{l}\text { Secretaria de } \\
\text { Assuntos } \\
\text { Estratégicos }\end{array}$ & Moreira Franco & PMDB & Moreira Franco & PMDB & Marcelo Neri & $\begin{array}{c}\text { Sem } \\
\text { partido }\end{array}$ & Marcelo Neri & $\begin{array}{l}\text { Sem } \\
\text { partido }\end{array}$ \\
\hline $\begin{array}{c}\text { Secretaria de } \\
\text { Comunicação } \\
\text { Social }\end{array}$ & Helena Chagas & $\begin{array}{l}\text { Sem } \\
\text { partido }\end{array}$ & Helena Chagas & $\begin{array}{l}\text { Sem } \\
\text { partido }\end{array}$ & Helena Chagas & $\begin{array}{c}\text { Sem } \\
\text { partido }\end{array}$ & $\begin{array}{l}\text { Thomas } \\
\text { Traumann }\end{array}$ & $\begin{array}{l}\text { Sem } \\
\text { partido }\end{array}$ \\
\hline $\begin{array}{c}\text { Secretaria de } \\
\text { Direitos Humanos }\end{array}$ & $\begin{array}{l}\text { Maria do } \\
\text { Rosário }\end{array}$ & PT & Maria do Rosário & PT & $\begin{array}{l}\text { Maria do } \\
\text { Rosário }\end{array}$ & PT & Ideli Savatti & PT \\
\hline $\begin{array}{c}\text { Secretaria de } \\
\text { Políticas para as } \\
\text { Mulheres }\end{array}$ & Iriny Lopes & PT & $\begin{array}{l}\text { Eleonora } \\
\text { Menicucci }\end{array}$ & PT & $\begin{array}{l}\text { Eleonora } \\
\text { Menicucci }\end{array}$ & PT & $\begin{array}{l}\text { Eleonora } \\
\text { Menicucci }\end{array}$ & PT \\
\hline
\end{tabular}




\begin{tabular}{|c|c|c|c|c|c|c|c|c|}
\hline $\begin{array}{l}\text { Secretaria de } \\
\text { Igualdade Racial }\end{array}$ & Luiza Bairros & PT & Luiza Bairros & PT & Luiza Bairros & PT & Luiza Bairros & PT \\
\hline $\begin{array}{c}\text { Relações } \\
\text { Institucionais }\end{array}$ & Luiz Sérgio & PT & Ideli Salvatti & PT & Ideli Salvatti & PT & Ricardo Berzoini & PT \\
\hline Secretaria-Geral & $\begin{array}{l}\text { Gilberto } \\
\text { Carvalho }\end{array}$ & PT & $\begin{array}{l}\text { Gilberto } \\
\text { Carvalho }\end{array}$ & PT & $\begin{array}{l}\text { Gilberto } \\
\text { Carvalho }\end{array}$ & PT & Gilberto Carvalho & PT \\
\hline $\begin{array}{l}\text { Trabalho e } \\
\text { Emprego }\end{array}$ & Carlos Lupi & PDT & Brizola Neto & PDT & Manoel Dias & PDT & Manoel Dias & PDT \\
\hline Transportes & $\begin{array}{c}\text { Alfredo } \\
\text { Nascimento }\end{array}$ & PR & Paulo Passos & PR & César Borges & PR & Paulo Passos & PR \\
\hline Turismo & Pedro Novais & PMDB & Gastão Vieira & PMDB & Gastão Vieira & PMDB & Vinícius Lages & PMDB \\
\hline $\begin{array}{l}\text { Secretaria de } \\
\text { Aviação Civil }\end{array}$ & $\begin{array}{c}\text { Wagner } \\
\text { Bittencourt }\end{array}$ & $\begin{array}{c}\text { Sem } \\
\text { partido }\end{array}$ & $\begin{array}{c}\text { Wagner } \\
\text { Bittencourt }\end{array}$ & $\begin{array}{l}\text { Sem } \\
\text { partido }\end{array}$ & Moreira Franco & PMDB & Moreira Franco & PMDB \\
\hline $\begin{array}{c}\text { Secretaria da Micro } \\
\text { e Pequena } \\
\text { Empresa }\end{array}$ & - & - & - & - & $\begin{array}{l}\text { Guilherme Afif } \\
\text { Domingos }\end{array}$ & PSD & $\begin{array}{l}\text { Guilherme Afif } \\
\text { Domingos }\end{array}$ & PSD \\
\hline
\end{tabular}

\begin{tabular}{|c|c|c|c|c|c|}
\hline GOVERNO DILMA II (2015) & \multicolumn{2}{|c|}{2015} & \multirow{2}{*}{$\begin{array}{c}\text { GOVERNO DILMA II (2016) } \\
\text { PASTA }\end{array}$} & \multicolumn{2}{|l|}{2016} \\
\hline PASTA & MINISTRO & PARTIDO & & MINISTRO & PARTIDO \\
\hline Advocacia Geral da União & $\begin{array}{l}\text { Luís Inácio Lucena } \\
\text { Adams }\end{array}$ & Sem partido & Advocacia Geral da União & José Eduardo Cardozo & PT \\
\hline $\begin{array}{l}\text { Agricultura, Pecuária e } \\
\text { Abastecimento }\end{array}$ & Kátia Abreu & PMDB & $\begin{array}{l}\text { Agricultura, Pecuária e } \\
\text { Abastecimento }\end{array}$ & Kátia Abreu & PMDB \\
\hline Banco Central do Brasil & Alexandre Tombini & Sem partido & Banco Central do Brasil & Alexandre Tombini & Sem partido \\
\hline Casa Civil & Aloizio Mercadante & PT & Casa Civil & Jaques Wagner & PT \\
\hline Cidades & Gilberto Kassab & PSD & Cidades & Gilberto Kassab & PSD \\
\hline $\begin{array}{c}\text { Ciência, Tecnologia e } \\
\text { Inovações }\end{array}$ & Aldo Rebelo & PCdoB & $\begin{array}{c}\text { Ciência, Tecnologia e } \\
\text { Inovações }\end{array}$ & Celso Pansera & PMDB \\
\hline Comunicações & Ricardo Berzoini & PT & Comunicações & André Figueiredo & PDT \\
\hline Controladoria Geral da União & Valdir Simão & Sem partido & Controladoria Geral da União & Carlos Higino & Sem partido \\
\hline Cultura & Juca Ferreira & PT & Cultura & Juca Ferreira & PT \\
\hline Defesa & Jaques Wagner & PT & Defesa & Aldo Rebelo & PCdoB \\
\hline Desenvolvimento Agrário & Patrus Ananias & PT & Desenvolvimento Agrário & Patrus Ananias & PT \\
\hline Desenvolvimento Social & Tereza Campelo & PT & Desenvolvimento Social & Tereza Campelo & PT \\
\hline $\begin{array}{c}\text { Desenvolvimento, Indústria e } \\
\text { Comércio }\end{array}$ & Armando Monteiro & PTB & $\begin{array}{c}\text { Desenvolvimento, Indústria e } \\
\text { Comércio }\end{array}$ & Armando Monteiro & PTB \\
\hline Educação & Cid Gomes & PROS & Educação & Aloizio Mercadante & PT \\
\hline Esporte & George Hilton & PRB & Esporte & George Hilton & PRB \\
\hline Fazenda & Joaquim Levy & Sem partido & Fazenda & Nelson Barbosa & Sem partido \\
\hline $\begin{array}{c}\text { Gabinete de Segurança } \\
\text { Institucional }\end{array}$ & $\begin{array}{l}\text { José Elito Carvalho } \\
\text { Siqueira }\end{array}$ & Sem partido & Integração Nacional & Gilberto Occhi & PP \\
\hline Integração Nacional & Gilberto Occhi & PP & Justiça & Eugênio Aragão & Sem partido \\
\hline Justiça & $\begin{array}{l}\text { José Eduardo } \\
\text { Cardozo }\end{array}$ & PT & Meio Ambiente & Izabella Teixeira & Sem partido \\
\hline Meio Ambiente & Izabella Teixeira & Sem partido & Minas e Energia & Eduardo Braga & PMDB \\
\hline Minas e Energia & Eduardo Braga & PMDB & $\begin{array}{c}\text { Mulheres, Igualdade Racial e } \\
\text { Direitos Humanos }\end{array}$ & Nilma Lino Gomes & Sem partido \\
\hline Pesca e Aquicultura & Helder Barbalho & PMDB & $\begin{array}{c}\text { Planejamento, Orçamento e } \\
\text { Gestão }\end{array}$ & Valdir Simão & Sem partido \\
\hline $\begin{array}{c}\text { Planejamento, Orçamento e } \\
\text { Gestão }\end{array}$ & Nelson Barbosa & Sem partido & Portos & Helder Barbalho & PMDB \\
\hline Portos & Edinho Araújo & PMDB & Relações Exteriores & Mauro Vieira & Sem partido \\
\hline Previdência Social & Carlos Gabas & PT & Saúde & Marcelo Castro & PMDB \\
\hline
\end{tabular}




\begin{tabular}{|c|c|c|c|c|c|}
\hline Relações Exteriores & Mauro Vieira & Sem partido & Secretaria de Aviação Civil & Eliseu Padilha & PMDB \\
\hline Saúde & Arthur Chioro & PT & $\begin{array}{l}\text { Secretaria de Comunicação } \\
\text { Social }\end{array}$ & Edinho Silva & PT \\
\hline $\begin{array}{c}\text { Secretaria de Assuntos } \\
\text { Estratégicos }\end{array}$ & Mangabeira Unger & Sem partido & Secretaria de Governo & Ricardo Berzoini & PT \\
\hline $\begin{array}{c}\text { Secretaria de Comunicação } \\
\text { Social }\end{array}$ & Thomas Traumann & Sem partido & $\begin{array}{l}\text { Trabalho, Emprego e } \\
\text { Previdência }\end{array}$ & Miguel Rossetto & PT \\
\hline $\begin{array}{c}\text { Secretaria de Direitos } \\
\text { Humanos }\end{array}$ & Ideli Savatti & PT & Transportes & Antônio Carlos Rodrigues & PR \\
\hline $\begin{array}{c}\text { Secretaria de Políticas para } \\
\text { as Mulheres }\end{array}$ & Eleonora Menicucci & PT & Turismo & Henrique Eduardo Alves & PMDB \\
\hline $\begin{array}{c}\text { Secretaria de Igualdade } \\
\text { Racial }\end{array}$ & Nilma Lino Gomes & Sem partido & & & \\
\hline Relações Institucionais & Pepe Vargas & PT & & & \\
\hline Secretaria-Geral & Miguel Rossetto & PT & & & \\
\hline Trabalho e Emprego & Manoel Dias & PDT & & & \\
\hline Transportes & $\begin{array}{c}\text { Antônio Carlos } \\
\text { Rodrigues }\end{array}$ & PR & & & \\
\hline Turismo & Vinícius Lages & PMDB & & & \\
\hline Secretaria de Aviação Civil & Eliseu Padilha & PMDB & & & \\
\hline $\begin{array}{l}\text { Secretaria da Micro e } \\
\text { Pequena Empresa }\end{array}$ & $\begin{array}{l}\text { Guilherme Afif } \\
\text { Domingos }\end{array}$ & PSD & & & \\
\hline
\end{tabular}

\begin{tabular}{|c|c|c|c|c|c|c|c|c|c|c|c|c|c|c|}
\hline MINISTÉRIOS & 2003 & 2004 & 2005 & 2006 & 2007 & 2008 & 2009 & 2010 & 2011 & 2012 & 2013 & 2014 & 2015 & 2016 \\
\hline $\begin{array}{c}\text { Agricultura, } \\
\text { Pecuária e } \\
\text { Abastecimento }\end{array}$ & $\begin{array}{c}\text { Sem } \\
\text { partido }\end{array}$ & $\begin{array}{c}\text { Sem } \\
\text { partido }\end{array}$ & $\begin{array}{c}\text { Sem } \\
\text { partido }\end{array}$ & PT & PMDB & PMDB & PMDB & PMDB & PMDB & PMDB & PMDB & PMDB & PMDB & PMDB \\
\hline $\begin{array}{c}\text { Ciência, } \\
\text { Tecnologia e } \\
\text { Inovações }\end{array}$ & PSB & PSB & PSB & PSB & PSB & PSB & PSB & PSB & PT & $\begin{array}{c}\text { Sem } \\
\text { partido }\end{array}$ & $\begin{array}{c}\text { Sem } \\
\text { partido }\end{array}$ & $\begin{array}{c}\text { Sem } \\
\text { partido }\end{array}$ & PCdoB & PMDB \\
\hline Fazenda & PT & PT & PT & PT & PT & PT & PT & PT & PT & PT & PT & PT & $\begin{array}{c}\text { Sem } \\
\text { partido }\end{array}$ & $\begin{array}{l}\text { Sem } \\
\text { partido }\end{array}$ \\
\hline Educação & PT & PT & PT & PT & PT & PT & PT & PT & PT & PT & PT & PT & PROS & PT \\
\hline $\begin{array}{c}\text { Desenvolvimento, } \\
\text { Indústria e } \\
\text { Comércio }\end{array}$ & $\begin{array}{c}\text { Sem } \\
\text { partido }\end{array}$ & $\begin{array}{c}\text { Sem } \\
\text { partido }\end{array}$ & $\begin{array}{c}\text { Sem } \\
\text { partido }\end{array}$ & $\begin{array}{c}\text { Sem } \\
\text { partido }\end{array}$ & $\begin{array}{l}\text { Sem } \\
\text { partido }\end{array}$ & $\begin{array}{l}\text { Sem } \\
\text { partido }\end{array}$ & $\begin{array}{l}\text { Sem } \\
\text { partido }\end{array}$ & $\begin{array}{l}\text { Sem } \\
\text { partido }\end{array}$ & PT & PT & PT & $\begin{array}{c}\text { Sem } \\
\text { partido }\end{array}$ & PTB & PTB \\
\hline Justiça & \begin{tabular}{|c|} 
Sem \\
partido
\end{tabular} & $\begin{array}{c}\text { Sem } \\
\text { partido }\end{array}$ & $\begin{array}{c}\text { Sem } \\
\text { partido }\end{array}$ & $\begin{array}{c}\text { Sem } \\
\text { partido }\end{array}$ & PT & PT & PT & $\begin{array}{c}\text { Sem } \\
\text { partido }\end{array}$ & PT & PT & PT & PT & PT & $\begin{array}{l}\text { Sem } \\
\text { partido }\end{array}$ \\
\hline Minas e Energia & PT & PT & PMDB & PMDB & PMDB & PMDB & PMDB & PMDB & PMDB & PMDB & PMDB & PMDB & PMDB & PMDB \\
\hline $\begin{array}{c}\text { Previdência } \\
\text { Social }\end{array}$ & PT & PMDB & PMDB & PT & PT & PT & PT & PT & PMDB & PMDB & PMDB & PMDB & PT & - \\
\hline $\begin{array}{l}\text { Relações } \\
\text { Exteriores }\end{array}$ & $\begin{array}{c}\text { Sem } \\
\text { partido }\end{array}$ & $\begin{array}{c}\text { Sem } \\
\text { partido }\end{array}$ & $\begin{array}{c}\text { Sem } \\
\text { partido }\end{array}$ & $\begin{array}{c}\text { Sem } \\
\text { partido }\end{array}$ & PT & PT & PT & PT & $\begin{array}{c}\text { Sem } \\
\text { partido }\end{array}$ & $\begin{array}{c}\text { Sem } \\
\text { partido }\end{array}$ & $\begin{array}{c}\text { Sem } \\
\text { partido }\end{array}$ & $\begin{array}{c}\text { Sem } \\
\text { partido }\end{array}$ & $\begin{array}{c}\text { Sem } \\
\text { partido }\end{array}$ & $\begin{array}{l}\text { Sem } \\
\text { partido }\end{array}$ \\
\hline Saúde & PT & PT & PMDB & PMDB & PMDB & PMDB & PMDB & PMDB & PT & $\begin{array}{l}\text { PT } \\
\end{array}$ & PT & PT & PT & PMDB \\
\hline $\begin{array}{l}\text { Trabalho e } \\
\text { Emprego }\end{array}$ & PT & PT & PT & PT & PDT & PDT & PDT & PDT & PDT & PDT & PDT & PDT & PDT & - \\
\hline Transportes & $\mathrm{PL}$ & $\mathrm{PL}$ & $\mathrm{PL}$ & $\mathrm{PL}$ & $\mathrm{PR}$ & $\mathrm{PR}$ & $\mathrm{PR}$ & PR & $\mathrm{PR}$ & PR & PR & $\mathrm{PR}$ & $\mathrm{PR}$ & PR \\
\hline Comunicações & PDT & PMDB & PMDB & PMDB & PMDB & PMDB & PMDB & PMDB & PT & PT & PT & PT & PT & PDT \\
\hline Cultura & $\begin{array}{c}\text { Sem } \\
\text { partido }\end{array}$ & $\begin{array}{c}\text { Sem } \\
\text { partido }\end{array}$ & $\begin{array}{c}\text { Sem } \\
\text { partido }\end{array}$ & $\begin{array}{c}\text { Sem } \\
\text { partido }\end{array}$ & $\begin{array}{c}\text { Sem } \\
\text { partido }\end{array}$ & PT & PT & PT & $\begin{array}{c}\text { Sem } \\
\text { partido }\end{array}$ & $\begin{array}{c}\text { Sem } \\
\text { partido }\end{array}$ & PT & PT & PT & PT \\
\hline Meio Ambiente & PT & PT & PT & PT & PT & PT & PT & $\begin{array}{c}\text { Sem } \\
\text { partido }\end{array}$ & $\begin{array}{c}\text { Sem } \\
\text { partido }\end{array}$ & $\begin{array}{c}\text { Sem } \\
\text { partido }\end{array}$ & $\begin{array}{c}\text { Sem } \\
\text { partido }\end{array}$ & $\begin{array}{c}\text { Sem } \\
\text { partido }\end{array}$ & $\begin{array}{c}\text { Sem } \\
\text { partido }\end{array}$ & $\begin{array}{l}\text { Sem } \\
\text { partido }\end{array}$ \\
\hline
\end{tabular}




\begin{tabular}{|c|c|c|c|c|c|c|c|c|c|c|c|c|c|c|}
\hline $\begin{array}{c}\text { Planejamento, } \\
\text { Orçamento e } \\
\text { Gestão }\end{array}$ & PT & PT & PT & PT & PT & PT & PT & PT & PT & PT & PT & PT & $\begin{array}{l}\text { Sem } \\
\text { partido }\end{array}$ & $\begin{array}{l}\text { Sem } \\
\text { partido }\end{array}$ \\
\hline $\begin{array}{c}\text { Desenvolvimento } \\
\text { Agrário }\end{array}$ & PT & PT & PT & PT & PT & PT & PT & PT & PT & PT & PT & PT & PT & PT \\
\hline Esporte & PCdoB & PCdoB & PCdoB & PCdoB & PCdoB & PCdoB & PCdoB & PCdoB & PCdoB & PCdoB & PCdoB & PCdoB & PRB & PRB \\
\hline Defesa & $\begin{array}{c}\text { Sem } \\
\text { partido }\end{array}$ & $\begin{array}{c}\text { Sem } \\
\text { partido }\end{array}$ & $\mathrm{PL}$ & PT & PMDB & PMDB & PMDB & PMDB & PMDB & PT & PT & PT & PT & PCdoB \\
\hline $\begin{array}{c}\text { Integração } \\
\text { Nacional }\end{array}$ & PPS & PPS & PSB & PSB & PMDB & PMDB & PMDB & PMDB & PSB & PSB & PSB & PROS & PP & PP \\
\hline Turismo & PTB & PTB & PTB & PTB & PT & PT & PT & PT & PMDB & PMDB & PMDB & PMDB & PMDB & PMDB \\
\hline $\begin{array}{c}\text { Desenvolvimento } \\
\text { Social }\end{array}$ & PT & PT & PT & PT & PT & PT & PT & PT & PT & PT & PT & PT & PT & PT \\
\hline Cidades & PT & PT & PP & PP & PP & PP & PP & PP & PP & PP & PP & PP & PSD & PSD \\
\hline $\begin{array}{c}\text { Pesca e } \\
\text { Aquicultura }\end{array}$ & PT & PT & PT & PT & PT & PT & PT & PT & PT & PRB & PRB & PRB & PMDB & - \\
\hline Portos & - & - & - & - & PSB & PSB & PSB & PSB & PSB & PSB & PSB & PR & PMDB & PMDB \\
\hline $\begin{array}{c}\text { Advocacia-Geral } \\
\text { da União }\end{array}$ & \begin{tabular}{|l} 
Sem \\
partido
\end{tabular} & $\begin{array}{c}\text { Sem } \\
\text { partido }\end{array}$ & $\begin{array}{c}\text { Sem } \\
\text { partido }\end{array}$ & $\begin{array}{c}\text { Sem } \\
\text { partido }\end{array}$ & $\begin{array}{c}\text { Sem } \\
\text { partido }\end{array}$ & $\begin{array}{c}\text { Sem } \\
\text { partido }\end{array}$ & $\begin{array}{c}\text { Sem } \\
\text { partido }\end{array}$ & \begin{tabular}{|c|} 
Sem \\
partido
\end{tabular} & $\begin{array}{c}\text { Sem } \\
\text { partido }\end{array}$ & $\begin{array}{c}\text { Sem } \\
\text { partido }\end{array}$ & $\begin{array}{c}\text { Sem } \\
\text { partido }\end{array}$ & $\begin{array}{c}\text { Sem } \\
\text { partido }\end{array}$ & $\begin{array}{c}\text { Sem } \\
\text { partido }\end{array}$ & PT \\
\hline $\begin{array}{l}\text { Controladoria- } \\
\text { Geral da União }\end{array}$ & PT & PT & PT & PT & PT & PT & PT & PT & PT & PT & PT & PT & $\begin{array}{c}\text { Sem } \\
\text { partido }\end{array}$ & $\begin{array}{l}\text { Sem } \\
\text { partido }\end{array}$ \\
\hline $\begin{array}{c}\text { Secretaria de } \\
\text { Direitos Humanos }\end{array}$ & PT & PT & PT & PT & PT & PT & PT & PT & PT & PT & PT & PT & PT & - \\
\hline $\begin{array}{c}\text { Secretaria da } \\
\text { Igualdade Racial }\end{array}$ & PT & PT & PT & PT & PT & PT & PT & PT & PT & PT & PT & PT & $\begin{array}{c}\text { Sem } \\
\text { partido }\end{array}$ & - \\
\hline $\begin{array}{c}\text { Secretaria de } \\
\text { Políticas para as } \\
\text { Mulheres }\end{array}$ & PT & PT & PT & PT & PT & PT & PT & PT & PT & PT & PT & PT & PT & - \\
\hline $\begin{array}{c}\text { Assuntos } \\
\text { Estratégicos }\end{array}$ & - & - & - & - & PRB & PRB & PRB & PT & PMDB & PMDB & $\begin{array}{c}\text { Sem } \\
\text { partido }\end{array}$ & $\begin{array}{c}\text { Sem } \\
\text { partido }\end{array}$ & $\begin{array}{c}\text { Sem } \\
\text { partido }\end{array}$ & - \\
\hline $\begin{array}{l}\text { Secretaria de } \\
\text { Aviação Civil }\end{array}$ & - & - & - & - & - & - & - & - & $\begin{array}{c}\text { Sem } \\
\text { partido }\end{array}$ & $\begin{array}{c}\text { Sem } \\
\text { partido }\end{array}$ & PMDB & PMDB & PMDB & PMDB \\
\hline $\begin{array}{c}\text { Secretaria da } \\
\text { Micro e Pequena } \\
\text { Empresa }\end{array}$ & - & - & - & - & - & - & - & - & - & - & PSD & PSD & PSD & - \\
\hline Trabalho & - & - & - & - & - & - & - & - & - & - & - & - & - & PT \\
\hline $\begin{array}{c}\text { Mulheres, } \\
\text { Igualdade Racial, } \\
\text { Juventude e } \\
\text { Direitos Humanos }\end{array}$ & - & - & - & - & - & - & - & - & - & - & - & - & - & $\begin{array}{l}\text { Sem } \\
\text { partido }\end{array}$ \\
\hline
\end{tabular}

Tabela 7. Orçamento de Investimento - Ministérios

\begin{tabular}{|c|c|c|c|c|c|c|c|c|c|c|c|c|c|c|}
\hline MINISTÉRIOS & 2003 & 2004 & 2005 & 2006 & 2007 & 2008 & 2009 & 2010 & 2011 & 2012 & 2013 & 2014 & 2015 & 2016 \\
\hline $\begin{array}{c}\text { Agricultura, } \\
\text { Pecuária e } \\
\text { Abastecimento }\end{array}$ & 73,9 & 138,8 & 255,3 & 316,2 & 481,3 & 594,0 & 939,1 & $1.087,8$ & 737,8 & 884,4 & 972,1 & 794,9 & 385,3 & 603,1 \\
\hline $\begin{array}{c}\text { Ciência, } \\
\text { Tecnologia e } \\
\text { Inovações }\end{array}$ & 199,2 & 227,7 & 475,4 & 932,6 & 938,1 & $1.101,6$ & $1.098,6$ & $1.481,7$ & $1.013,2$ & $1.120,2$ & $1.143,6$ & 877,7 & 478,3 & 576,4 \\
\hline Fazenda & 48,4 & 70,1 & 339,4 & 277,5 & 164,0 & 68,2 & 103,3 & 206,7 & 312,6 & 616,1 & 818,1 & 570,0 & 445,1 & 453,1 \\
\hline Educação & 443,5 & 476,9 & 965,2 & $1.038,9$ & $2.757,2$ & $2.988,2$ & $4.556,6$ & $6.037,9$ & $7.701,7$ & $12.753,2$ & $10.638,7$ & $9.924,5$ & $5.383,1$ & $5.171,0$ \\
\hline $\begin{array}{c}\text { Desenvolvimento, } \\
\text { Indústria e } \\
\text { Comércio }\end{array}$ & 52,9 & 115,1 & 83,9 & 61,2 & 190,6 & 60,9 & 68,8 & 69,4 & 46,8 & 111,2 & 125,8 & 68,5 & 25,2 & 182,8 \\
\hline Justiça & 449,8 & 532,6 & 508,8 & 722,4 & 876,9 & $1.177,8$ & 675,2 & 707,3 & 597,9 & $1.629,5$ & $1.675,7$ & $1.181,5$ & 661,6 & $1.835,1$ \\
\hline Minas e Energia & 14,2 & 45,3 & 19,1 & 23,7 & 33,1 & 26,9 & 44,5 & 46,8 & 44,9 & 81,7 & 116,6 & 58,6 & 47,3 & 58,0 \\
\hline
\end{tabular}




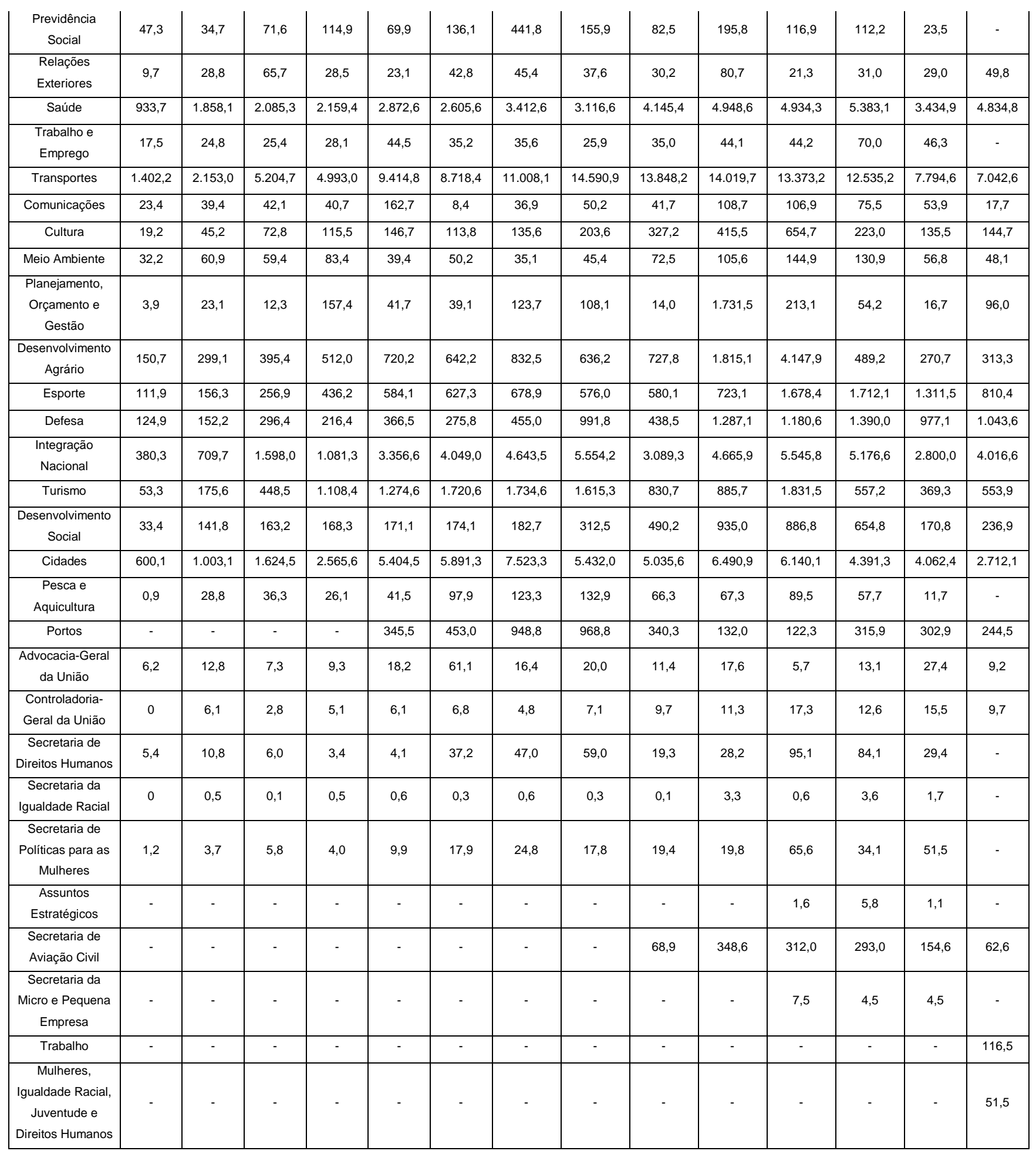

Fonte: Banco de dados do SIAFI. Valor empenhado, em milhões de reais. 


\section{ANEXO C - EMPRESAS ESTATAIS}

Tabela 8. Dirigentes - Principais Empresas Estatais

\begin{tabular}{|c|c|c|c|c|c|c|c|c|c|c|c|c|c|c|}
\hline $\begin{array}{c}\text { EMPRESAS } \\
\text { ESTATAIS }\end{array}$ & 2003 & 2004 & 2005 & 2006 & 2007 & 2008 & 2009 & 2010 & 2011 & 2012 & 2013 & 2014 & 2015 & 2016 \\
\hline \multirow[t]{2}{*}{ PETROBRAS } & $\begin{array}{l}\text { José } \\
\text { Eduardo } \\
\text { Dutra }\end{array}$ & $\begin{array}{c}\text { José } \\
\text { Eduardo } \\
\text { Dutra }\end{array}$ & $\begin{array}{l}\text { Sérgio } \\
\text { Gabrielli }\end{array}$ & $\begin{array}{l}\text { Sérgio } \\
\text { Gabrielli }\end{array}$ & $\begin{array}{l}\text { Sérgio } \\
\text { Gabrielli }\end{array}$ & $\begin{array}{l}\text { Sérgio } \\
\text { Gabrielli }\end{array}$ & $\begin{array}{l}\text { Sérgio } \\
\text { Gabrielli }\end{array}$ & $\begin{array}{l}\text { Sérgio } \\
\text { Gabrielli }\end{array}$ & $\begin{array}{l}\text { Sérgio } \\
\text { Gabrielli }\end{array}$ & $\begin{array}{l}\text { Graça } \\
\text { Foster }\end{array}$ & $\begin{array}{l}\text { Graça } \\
\text { Foster }\end{array}$ & $\begin{array}{l}\text { Graça } \\
\text { Foster }\end{array}$ & $\begin{array}{l}\text { Aldemir } \\
\text { Bendine }\end{array}$ & $\begin{array}{l}\text { Aldemir } \\
\text { Bendine }\end{array}$ \\
\hline & PT & PT & PT & PT & PT & PT & PT & PT & PT & PT & PT & PT & PT & PT \\
\hline \multirow{2}{*}{ TRANSPETRO } & $\begin{array}{c}\text { Sérgio } \\
\text { Machado }\end{array}$ & $\begin{array}{l}\text { Sérgio } \\
\text { Machado }\end{array}$ & $\begin{array}{l}\text { Sérgio } \\
\text { Machado }\end{array}$ & $\begin{array}{l}\text { Sérgio } \\
\text { Machado }\end{array}$ & $\begin{array}{c}\text { Sérgio } \\
\text { Machado }\end{array}$ & $\begin{array}{l}\text { Sérgio } \\
\text { Machado }\end{array}$ & $\begin{array}{l}\text { Sérgio } \\
\text { Machado }\end{array}$ & $\begin{array}{c}\text { Sérgio } \\
\text { Machado }\end{array}$ & $\begin{array}{c}\text { Sérgio } \\
\text { Machado }\end{array}$ & $\begin{array}{c}\text { Sérgio } \\
\text { Machado }\end{array}$ & $\begin{array}{l}\text { Sérgio } \\
\text { Machado }\end{array}$ & $\begin{array}{l}\text { Sérgio } \\
\text { Machado }\end{array}$ & $\begin{array}{l}\text { Antônio } \\
\text { Silvino }\end{array}$ & $\begin{array}{l}\text { Antônio } \\
\text { Silvino }\end{array}$ \\
\hline & PMDB & PMDB & PMDB & PMDB & PMDB & PMDB & PMDB & PMDB & PMDB & PMDB & PMDB & PMDB & Sem partido & $\begin{array}{l}\text { Sem } \\
\text { partido }\end{array}$ \\
\hline \multirow[t]{2}{*}{ ELETROBRAS } & $\begin{array}{l}\text { Luiz } \\
\text { Pinguelli } \\
\text { Rosa }\end{array}$ & $\begin{array}{c}\text { Silas } \\
\text { Rondeau }\end{array}$ & $\begin{array}{c}\text { Aloísio } \\
\text { Vasconcelos }\end{array}$ & $\begin{array}{c}\text { Aloísio } \\
\text { Vasconcelos }\end{array}$ & $\begin{array}{l}\text { Valter } \\
\text { Cardeal }\end{array}$ & $\begin{array}{c}\text { José } \\
\text { Antonio } \\
\text { Muniz }\end{array}$ & $\begin{array}{c}\text { José } \\
\text { Antonio } \\
\text { Muniz }\end{array}$ & $\begin{array}{c}\text { José } \\
\text { Antonio } \\
\text { Muniz }\end{array}$ & $\begin{array}{c}\text { José } \\
\text { Costa } \\
\text { Carvalho } \\
\text { Neto }\end{array}$ & $\begin{array}{c}\text { José } \\
\text { Costa } \\
\text { Carvalho } \\
\text { Neto }\end{array}$ & $\begin{array}{c}\text { José Costa } \\
\text { Carvalho } \\
\text { Neto }\end{array}$ & $\begin{array}{l}\text { José Costa } \\
\text { Carvalho } \\
\text { Neto }\end{array}$ & $\begin{array}{l}\text { José Costa } \\
\text { Carvalho } \\
\text { Neto }\end{array}$ & $\begin{array}{c}\text { José } \\
\text { Costa } \\
\text { Carvalho } \\
\text { Neto }\end{array}$ \\
\hline & PT & PMDB & PMDB & PMDB & PT & PMDB & PMDB & PMDB & $\begin{array}{l}\text { Sem } \\
\text { partido }\end{array}$ & $\begin{array}{c}\text { Sem } \\
\text { partido }\end{array}$ & Sem partido & Sem partido & Sem partido & $\begin{array}{l}\text { Sem } \\
\text { partido }\end{array}$ \\
\hline \multirow[t]{2}{*}{ ELETRONORTE } & $\begin{array}{c}\text { Silas } \\
\text { Rondeau }\end{array}$ & $\begin{array}{l}\text { Roberto } \\
\text { Salmeron }\end{array}$ & $\begin{array}{c}\text { Carlos } \\
\text { Nascimento }\end{array}$ & $\begin{array}{c}\text { Carlos } \\
\text { Nascimento }\end{array}$ & $\begin{array}{c}\text { Carlos } \\
\text { Nascimento }\end{array}$ & $\begin{array}{l}\text { Jorge } \\
\text { Palmeira }\end{array}$ & $\begin{array}{l}\text { Jorge } \\
\text { Palmeira }\end{array}$ & $\begin{array}{c}\text { Jorge } \\
\text { Palmeira }\end{array}$ & $\begin{array}{c}\text { Josias } \\
\text { Matos de } \\
\text { Araújo }\end{array}$ & $\begin{array}{c}\text { Josias } \\
\text { Matos de } \\
\text { Araújo }\end{array}$ & $\begin{array}{l}\text { Josias } \\
\text { Matos de } \\
\text { Araújo }\end{array}$ & $\begin{array}{l}\text { Tito } \\
\text { Cardoso de } \\
\text { Oliveira }\end{array}$ & $\begin{array}{c}\text { Tito Cardoso } \\
\text { de Oliveira }\end{array}$ & $\begin{array}{l}\text { Tito } \\
\text { Cardoso } \\
\text { de } \\
\text { Oliveira }\end{array}$ \\
\hline & PMDB & PTB & PMDB & PMDB & PMDB & PMDB & PMDB & PMDB & PMDB & PMDB & PMDB & PMDB & PMDB & PMDB \\
\hline \multirow[t]{2}{*}{ CHESF } & $\begin{array}{l}\text { Dilton da } \\
\text { Conti }\end{array}$ & $\begin{array}{c}\text { Dilton da } \\
\text { Conti }\end{array}$ & $\begin{array}{l}\text { Dilton da } \\
\text { Conti }\end{array}$ & $\begin{array}{l}\text { Dilton da } \\
\text { Conti }\end{array}$ & $\begin{array}{l}\text { Dilton da } \\
\text { Conti }\end{array}$ & $\begin{array}{l}\text { Dilton da } \\
\text { Conti }\end{array}$ & $\begin{array}{l}\text { Dilton da } \\
\text { Conti }\end{array}$ & $\begin{array}{c}\text { Dilton da } \\
\text { Conti }\end{array}$ & $\begin{array}{l}\text { Dilton da } \\
\text { Conti }\end{array}$ & $\begin{array}{c}\text { João } \\
\text { Bosco de } \\
\text { Almeida }\end{array}$ & $\begin{array}{l}\text { João Bosco } \\
\text { de Almeida }\end{array}$ & $\begin{array}{l}\text { Antonio } \\
\text { Varejão }\end{array}$ & $\begin{array}{l}\text { Antonio } \\
\text { Varejão }\end{array}$ & $\begin{array}{c}\text { José } \\
\text { Carlos de } \\
\text { Miranda }\end{array}$ \\
\hline & PSB & PSB & PSB & PSB & PSB & PSB & PSB & PSB & PSB & PSB & PSB & PP & PP & $\begin{array}{l}\text { Sem } \\
\text { partido }\end{array}$ \\
\hline \multirow{2}{*}{$\begin{array}{c}\text { ELETRO } \\
\text { NUCLEAR }\end{array}$} & $\begin{array}{c}\text { Zieli Dutra } \\
\text { Thomé } \\
\text { Filho }\end{array}$ & $\begin{array}{l}\text { Zieli Dutra } \\
\text { Thomé Filho }\end{array}$ & $\begin{array}{l}\text { Othon Luiz } \\
\text { Pinheiro }\end{array}$ & $\begin{array}{l}\text { Othon Luiz } \\
\text { Pinheiro }\end{array}$ & $\begin{array}{l}\text { Othon Luiz } \\
\text { Pinheiro }\end{array}$ & $\begin{array}{l}\text { Othon Luiz } \\
\text { Pinheiro }\end{array}$ & $\begin{array}{l}\text { Othon Luiz } \\
\text { Pinheiro }\end{array}$ & $\begin{array}{l}\text { Othon Luiz } \\
\text { Pinheiro }\end{array}$ & $\begin{array}{c}\text { Othon Luiz } \\
\text { Pinheiro }\end{array}$ & $\begin{array}{l}\text { Othon Luiz } \\
\text { Pinheiro }\end{array}$ & $\begin{array}{l}\text { Othon Luiz } \\
\text { Pinheiro }\end{array}$ & $\begin{array}{l}\text { Othon Luiz } \\
\text { Pinheiro }\end{array}$ & $\begin{array}{l}\text { Pedro Diniz } \\
\text { de } \\
\text { Figueiredo }\end{array}$ & $\begin{array}{c}\text { Pedro } \\
\text { Diniz de } \\
\text { Figueiredo }\end{array}$ \\
\hline & $\begin{array}{l}\text { Sem } \\
\text { partido }\end{array}$ & Sem partido & PT & PT & PT & PT & PT & PT & PT & PT & PT & PT & Sem partido & $\begin{array}{l}\text { Sem } \\
\text { partido }\end{array}$ \\
\hline \multirow[t]{2}{*}{ ELETROSUL } & $\begin{array}{l}\text { Milton } \\
\text { Mendes }\end{array}$ & $\begin{array}{l}\text { Milton } \\
\text { Mendes }\end{array}$ & $\begin{array}{l}\text { Milton } \\
\text { Mendes }\end{array}$ & $\begin{array}{l}\text { José } \\
\text { Drumond } \\
\text { Saraiva }\end{array}$ & $\begin{array}{l}\text { Ronaldo } \\
\text { Custódio }\end{array}$ & $\begin{array}{c}\text { Eurides } \\
\text { Mescolotto }\end{array}$ & $\begin{array}{c}\text { Eurides } \\
\text { Mescolotto }\end{array}$ & $\begin{array}{c}\text { Eurides } \\
\text { Mescolotto }\end{array}$ & $\begin{array}{c}\text { Eurides } \\
\text { Mescolotto }\end{array}$ & $\begin{array}{c}\text { Eurides } \\
\text { Mescolotto }\end{array}$ & $\begin{array}{c}\text { Eurides } \\
\text { Mescolotto }\end{array}$ & $\begin{array}{l}\text { Eurides } \\
\text { Mescolotto }\end{array}$ & $\begin{array}{c}\text { Márcio } \\
\text { Zimmermann }\end{array}$ & $\begin{array}{l}\text { Djalma } \\
\text { Berger }\end{array}$ \\
\hline & PT & PT & PT & PT & $\begin{array}{l}\text { Sem } \\
\text { partido }\end{array}$ & PT & PT & PT & PT & PT & PT & PT & PMDB & PMDB \\
\hline \multirow{2}{*}{ FURNAS } & $\begin{array}{l}\text { José Pedro } \\
\text { Rodrigues }\end{array}$ & $\begin{array}{l}\text { José Pedro } \\
\text { Rodrigues }\end{array}$ & $\begin{array}{c}\text { José Pedro } \\
\text { Rodrigues }\end{array}$ & $\begin{array}{l}\text { José Pedro } \\
\text { Rodrigues }\end{array}$ & $\begin{array}{l}\text { Luiz Paulo } \\
\text { Conde }\end{array}$ & $\begin{array}{l}\text { Luiz Paulo } \\
\text { Conde }\end{array}$ & $\begin{array}{l}\text { Carlos } \\
\text { Nadalutti }\end{array}$ & $\begin{array}{c}\text { Carlos } \\
\text { Nadalutti }\end{array}$ & $\begin{array}{l}\text { Flávio } \\
\text { Decat }\end{array}$ & $\begin{array}{l}\text { Flávio } \\
\text { Decat }\end{array}$ & $\begin{array}{l}\text { Flávio } \\
\text { Decat }\end{array}$ & Flávio Decat & Flávio Decat & $\begin{array}{l}\text { Flávio } \\
\text { Decat }\end{array}$ \\
\hline & PMDB & PMDB & PMDB & PMDB & PMDB & PMDB & PMDB & PMDB & PMDB & PMDB & PMDB & PMDB & PMDB & PMDB \\
\hline \multirow[t]{2}{*}{ INFRAERO } & $\begin{array}{l}\text { Carlos } \\
\text { Wilson }\end{array}$ & $\begin{array}{l}\text { Carlos } \\
\text { Wilson }\end{array}$ & $\begin{array}{l}\text { Carlos } \\
\text { Wilson }\end{array}$ & $\begin{array}{c}\text { José Carlos } \\
\text { Pereira }\end{array}$ & $\begin{array}{c}\text { Sergio } \\
\text { Gaudenzi }\end{array}$ & $\begin{array}{c}\text { Sergio } \\
\text { Gaudenzi }\end{array}$ & $\begin{array}{l}\text { Cleonilson } \\
\text { Nicácio } \\
\text { Silva }\end{array}$ & $\begin{array}{c}\text { Murilo } \\
\text { Marques } \\
\text { Barboza }\end{array}$ & $\begin{array}{l}\text { Gustavo } \\
\text { do Vale }\end{array}$ & $\begin{array}{l}\text { Gustavo } \\
\text { do Vale }\end{array}$ & $\begin{array}{c}\text { Gustavo do } \\
\text { Vale }\end{array}$ & $\begin{array}{c}\text { Gustavo do } \\
\text { Vale }\end{array}$ & $\begin{array}{c}\text { Gustavo do } \\
\text { Vale }\end{array}$ & $\begin{array}{l}\text { Gustavo } \\
\text { do Vale }\end{array}$ \\
\hline & PT & PT & PT & Sem partido & PSB & PSB & Sem partido & $\begin{array}{l}\text { Sem } \\
\text { partido }\end{array}$ & $\begin{array}{c}\text { Sem } \\
\text { partido }\end{array}$ & $\begin{array}{l}\text { Sem } \\
\text { partido }\end{array}$ & Sem partido & Sem partido & Sem partido & $\begin{array}{l}\text { Sem } \\
\text { partido }\end{array}$ \\
\hline \multirow{2}{*}{$\begin{array}{c}\text { BANCO DO } \\
\text { BRASIL }\end{array}$} & $\begin{array}{l}\text { Cassio } \\
\text { Casseb }\end{array}$ & $\begin{array}{l}\text { Cassio } \\
\text { Casseb }\end{array}$ & $\begin{array}{c}\text { Rossano } \\
\text { Maranhão }\end{array}$ & $\begin{array}{c}\text { Rossano } \\
\text { Maranhão }\end{array}$ & $\begin{array}{c}\text { Antonio } \\
\text { Lima Neto }\end{array}$ & $\begin{array}{c}\text { Antonio } \\
\text { Lima Neto }\end{array}$ & $\begin{array}{l}\text { Aldemir } \\
\text { Bendine }\end{array}$ & $\begin{array}{l}\text { Aldemir } \\
\text { Bendine }\end{array}$ & $\begin{array}{l}\text { Aldemir } \\
\text { Bendine }\end{array}$ & $\begin{array}{l}\text { Aldemir } \\
\text { Bendine }\end{array}$ & $\begin{array}{l}\text { Aldemir } \\
\text { Bendine }\end{array}$ & $\begin{array}{l}\text { Aldemir } \\
\text { Bendine }\end{array}$ & $\begin{array}{c}\text { Alexandre } \\
\text { Abreu }\end{array}$ & $\begin{array}{c}\text { Alexandre } \\
\text { Abreu }\end{array}$ \\
\hline & PT & PT & Sem partido & Sem partido & $\begin{array}{l}\text { Sem } \\
\text { partido }\end{array}$ & $\begin{array}{c}\text { Sem } \\
\text { partido }\end{array}$ & PT & PT & PT & PT & PT & PT & Sem partido & $\begin{array}{l}\text { Sem } \\
\text { partido }\end{array}$ \\
\hline \multirow{2}{*}{$\begin{array}{c}\text { CAIXA } \\
\text { ECONÔMICA } \\
\text { FEDERAL }\end{array}$} & $\begin{array}{l}\text { Jorge } \\
\text { Mattoso }\end{array}$ & $\begin{array}{c}\text { Jorge } \\
\text { Mattoso }\end{array}$ & $\begin{array}{l}\text { Jorge } \\
\text { Mattoso }\end{array}$ & $\begin{array}{l}\text { Maria } \\
\text { Fernanda } \\
\text { Coelho }\end{array}$ & $\begin{array}{c}\text { Maria } \\
\text { Fernanda } \\
\text { Coelho }\end{array}$ & $\begin{array}{c}\text { Maria } \\
\text { Fernanda } \\
\text { Coelho }\end{array}$ & $\begin{array}{c}\text { Maria } \\
\text { Fernanda } \\
\text { Coelho }\end{array}$ & $\begin{array}{c}\text { Maria } \\
\text { Fernanda } \\
\text { Coelho }\end{array}$ & $\begin{array}{l}\text { Jorge } \\
\text { Hereda }\end{array}$ & $\begin{array}{l}\text { Jorge } \\
\text { Hereda }\end{array}$ & $\begin{array}{l}\text { Jorge } \\
\text { Hereda }\end{array}$ & $\begin{array}{l}\text { Jorge } \\
\text { Hereda }\end{array}$ & $\begin{array}{l}\text { Miriam } \\
\text { Belchior }\end{array}$ & $\begin{array}{l}\text { Miriam } \\
\text { Belchior }\end{array}$ \\
\hline & PT & PT & PT & PT & PT & PT & PT & PT & PT & PT & PT & PT & PT & PT \\
\hline
\end{tabular}

\begin{tabular}{|c|c|c|c|c|c|c|c|c|c|c|c|c|c|c|}
\hline EMPRESAS ESTATAIS & 2003 & 2004 & 2005 & 2006 & 2007 & 2008 & 2009 & 2010 & 2011 & 2012 & 2013 & 2014 & 2015 & 2016 \\
\hline PETROBRAS & PT & PT & PT & PT & PT & PT & PT & PT & PT & PT & PT & PT & PT & PT \\
\hline TRANSPETRO & PMDB & PMDB & PMDB & PMDB & PMDB & PMDB & PMDB & PMDB & PMDB & PMDB & PMDB & PMDB & $\begin{array}{c}\text { Sem } \\
\text { partido }\end{array}$ & $\begin{array}{c}\text { Sem } \\
\text { partido }\end{array}$ \\
\hline ELETROBRAS & PT & PMDB & PMDB & PMDB & PT & PMDB & PMDB & PMDB & $\begin{array}{c}\text { Sem } \\
\text { partido }\end{array}$ & $\begin{array}{c}\text { Sem } \\
\text { partido }\end{array}$ & $\begin{array}{c}\text { Sem } \\
\text { partido }\end{array}$ & $\begin{array}{c}\text { Sem } \\
\text { partido }\end{array}$ & $\begin{array}{c}\text { Sem } \\
\text { partido }\end{array}$ & $\begin{array}{c}\text { Sem } \\
\text { partido }\end{array}$ \\
\hline ELETRONORTE & PMDB & PTB & PMDB & PMDB & PMDB & PMDB & PMDB & PMDB & PMDB & PMDB & PMDB & PMDB & PMDB & PMDB \\
\hline CHESF & PSB & PSB & PSB & PSB & PSB & PSB & PSB & PSB & PSB & PSB & PSB & PP & PP & $\begin{array}{c}\text { Sem } \\
\text { partido }\end{array}$ \\
\hline ELETRONUCLEAR & $\begin{array}{c}\text { Sem } \\
\text { partido }\end{array}$ & $\begin{array}{c}\text { Sem } \\
\text { partido }\end{array}$ & PT & PT & PT & PT & PT & PT & PT & PT & PT & PT & $\begin{array}{c}\text { Sem } \\
\text { partido }\end{array}$ & $\begin{array}{c}\text { Sem } \\
\text { partido }\end{array}$ \\
\hline
\end{tabular}




\begin{tabular}{|c|c|c|c|c|c|c|c|c|c|c|c|c|c|c|}
\hline ELETROSUL & PT & PT & PT & PT & $\begin{array}{l}\text { Sem } \\
\text { partido }\end{array}$ & PT & PT & PT & PT & PT & PT & PT & PMDB & PMDB \\
\hline FURNAS & PMDB & PMDB & PMDB & PMDB & PMDB & PMDB & PMDB & PMDB & PMDB & PMDB & PMDB & PMDB & PMDB & PMDB \\
\hline INFRAERO & PT & PT & PT & $\begin{array}{c}\text { Sem } \\
\text { partido }\end{array}$ & PSB & PSB & $\begin{array}{c}\text { Sem } \\
\text { partido }\end{array}$ & $\begin{array}{c}\text { Sem } \\
\text { partido }\end{array}$ & $\begin{array}{c}\text { Sem } \\
\text { partido }\end{array}$ & $\begin{array}{c}\text { Sem } \\
\text { partido }\end{array}$ & $\begin{array}{c}\text { Sem } \\
\text { partido }\end{array}$ & $\begin{array}{c}\text { Sem } \\
\text { partido }\end{array}$ & $\begin{array}{l}\text { Sem } \\
\text { partido }\end{array}$ & $\begin{array}{c}\text { Sem } \\
\text { partido }\end{array}$ \\
\hline BANCO DO BRASIL & PT & PT & $\begin{array}{c}\text { Sem } \\
\text { partido }\end{array}$ & $\begin{array}{c}\text { Sem } \\
\text { partido }\end{array}$ & $\begin{array}{c}\text { Sem } \\
\text { partido }\end{array}$ & $\begin{array}{c}\text { Sem } \\
\text { partido }\end{array}$ & PT & PT & PT & PT & PT & PT & $\begin{array}{c}\text { Sem } \\
\text { partido }\end{array}$ & $\begin{array}{c}\text { Sem } \\
\text { partido }\end{array}$ \\
\hline $\begin{array}{c}\text { CAIXA ECONÔMICA } \\
\text { FEDERAL }\end{array}$ & PT & PT & PT & PT & PT & PT & PT & PT & PT & PT & PT & PT & PT & PT \\
\hline
\end{tabular}

Tabela 9. Investimentos - Empresas Estatais

\begin{tabular}{|c|c|c|c|c|c|c|c|c|c|c|c|c|c|c|}
\hline $\begin{array}{c}\text { EMPRESAS } \\
\text { ESTATAIS }\end{array}$ & 2003 & 2004 & 2005 & 2006 & 2007 & 2008 & 2009 & 2010 & 2011 & 2012 & 2013 & 2014 & 2015 & 2016 \\
\hline PETROBRAS & 12.248 & 13.259 & 14.885 & 16.520 & 22.310 & 33.196 & 41.818 & 47.382 & 45.895 & 58.526 & 72.678 & 65.564 & 51.905 & 35.156 \\
\hline TRANSPETRO & 33 & 35 & 15 & 54 & 366 & 323 & 776 & 1.081 & 916 & 1.311 & 1.466 & 1.573 & 1.645 & 1.146 \\
\hline ELETROBRAS & 68 & 19 & 8 & 6 & 8 & 31 & 54 & 96 & 15 & 15 & 24 & 33 & 24 & 5 \\
\hline ELETRONORTE & 839 & 776 & 898 & 659 & 573 & 423 & 491 & 418 & 391 & 348 & 359 & 378 & 575 & 419 \\
\hline CHESF & 515 & 602 & 486 & 543 & 524 & 589 & 749 & 789 & 1.145 & 1.152 & 1.388 & 1.237 & 921 & 740 \\
\hline ELETRONUCLEAR & 164 & 246 & 258 & 255 & 308 & 299 & 545 & 531 & 1.273 & 740 & 1.651 & 1.987 & 1.930 & 890 \\
\hline ELETROSUL & 124 & 168 & 268 & 298 & 298 & 412 & 552 & 627 & 620 & 469 & 321 & 290 & 302 & 140 \\
\hline FURNAS & 1.046 & 788 & 918 & 876 & 822 & 1.087 & 1.433 & 1.245 & 987 & 1.147 & 944 & 849 & 729 & 499 \\
\hline INFRAERO & 55 & 44 & 277 & 592 & 524 & 376 & 421 & 643 & 1.144 & 1.315 & 1.640 & 1.424 & 1.065 & 683 \\
\hline BANCO DO BRASIL & 875 & 846 & 1.247 & 1.125 & 1.433 & 4.278 & 3.205 & 2.134 & 1.890 & 2.317 & 1.784 & 2.270 & 1.712 & 1.560 \\
\hline $\begin{array}{c}\text { CAIXA ECONÔMICA } \\
\text { FEDERAL }\end{array}$ & 439 & 432 & 327 & 458 & 337 & 438 & 462 & 584 & 498 & 930 & 1.754 & 1.887 & 1.344 & 930 \\
\hline
\end{tabular}

Fonte: Programa de Dispêndios Globais - PDG. Valor em milhões de reais.

Tabela 10. Investimentos - Empresas Estatais - Por Partido

\begin{tabular}{|c|c|c|c|c|c|c|c|c|c|c|c|c|c|c|}
\hline PARTIDO & 2003 & 2004 & 2005 & 2006 & 2007 & 2008 & 2009 & 2010 & 2011 & 2012 & 2013 & 2014 & 2015 & 2016 \\
\hline PT & 13.809 & 14.749 & 16.015 & 17.531 & 22.963 & 34.345 & 46.582 & 51.258 & 50.176 & 62.982 & 78.188 & 71.998 & 53.249 & 36.086 \\
\hline $\begin{array}{c}\text { PT (sem } \\
\text { Petrobras) }\end{array}$ & 1.561 & 1.490 & 1.130 & 1.011 & 653 & 1.149 & 4.764 & 3.876 & 4.281 & 4.456 & 5.510 & 6.434 & 1.344 & 930 \\
\hline PMDB & 1.918 & 842 & 1.839 & 1.595 & 1.761 & 1.864 & 2.754 & 2.840 & 2.294 & 2.806 & 2.769 & 2.800 & 1.606 & 1.058 \\
\hline PSB & 515 & 602 & 486 & 543 & 1.048 & 965 & 749 & 789 & 1.145 & 1.152 & 1.388 & 0 & 0 & 0 \\
\hline PP & 0 & 0 & 0 & 0 & 0 & 0 & 0 & 0 & 0 & 0 & 0 & 1.237 & 921 & 0 \\
\hline PTB & 0 & 776 & 0 & 0 & 0 & 0 & 0 & 0 & 0 & 0 & 0 & 0 & 0 & 0 \\
\hline SEM PARTIDO & 164 & 246 & 1.247 & 1.717 & 1.731 & 4.278 & 421 & 643 & 1.159 & 1.330 & 1.664 & 1.457 & 6.376 & 5.024 \\
\hline TOTAL & 16.406 & 17.215 & 19.587 & 21.386 & 27.503 & 41.452 & 50.506 & 55.530 & 54.774 & 68.270 & 84.009 & 77.492 & 62.152 & 42.168 \\
\hline
\end{tabular}

Fonte: Programa de Dispêndios Globais - PDG. Valor em milhões de reais. 